\author{
UNIVERSIDADE DE SÃO PAULO \\ FACULDADE DE FILOSOFIA, LETRAS E CIÊNCIAS HUMANAS \\ DEPARTAMENTO DE HISTÓRIA \\ PROGRAMA DE PÓS- GRADUAÇÃO EM HISTÓRIA SOCIAL
}

Luciane Munhoz de Omena

\title{
Pequenos poderes na Roma imperial: o povo miúdo na ótica de Sêneca
}




\title{
Pequenos poderes na Roma imperial: o povo miúdo na ótica de Sêneca
}

\author{
Tese apresentada no Programa de Pós- \\ Graduação em História Social, do \\ departamento de História da Faculdade de \\ Filosofia, Letras e Ciências Humanas, da \\ Universidade de São Paulo, para obtenção do \\ título de Doutora em História.
}

Orientador: Prof. Dr. Norberto Luiz Guarinello.

São Paulo 
AUTORIZO A REPRODUÇÃO E DIVULGAÇÃO TOTAL E PARCIALDESTE TRABALHO, POR QUALQUER MEIO CONVENCIONAL OU ELETRÔNICO. PARA FINS DE ESTUDO E PESQUISA, DESDE QUE CITADA A FONTE.

Serviço de Biblioteca e Documentação da Faculdade de Filosofia, Letras e Ciências Sociais da Universidade de São Paulo.

Omena, Luciane Munhoz de.

Pequenos Poderes na Roma Imperial: o povo miúdo sob a ótica de Sêneca/Luciane Munhoz de Omena; orientador Norberto Luiz Guarinello.

-- São Paulo, SP: 2007.

$224 f$.

Tese (Doutorado - Programa de Pós-Graduação em História Social. Área de Concentração: História Social) - Departamento de História da Faculdade de Filosofia, Letras e Ciências Humanas da Universidade de São Paulo.

1. Seneca, Lucius Anneus, 4 a.C. -65 d.C. 2. Roma Antiga (Historiografia; Sociedade; Política). 3 Poder - Roma Antiga. I. Título.

21름 937.06 
À minha filha e companheiro, Sophia e Francisco. A meus pais, Djalma e Sônia. 


\section{AGRADECIMENTOS}

O término dessa pesquisa se deve ao caminho partilhado com algumas pessoas que colaboraram para a sua construção. Tentarei lembrar de todos, tendo a certeza de que os agradecimentos são ínfimos por tão profunda contribuição.

No espaço institucional, foi relevante o financiamento recebido da FAPESP (Fundação de Amparo à Pesquisa do Estado de São Paulo), pela bolsa de doutorado concedida entre 2003 e 2006 (processo 03/00818-1), que garantiu a compra de materiais, participação em congressos, assegurando, dessa forma, o debate e a troca de idéias, inestimáveis para meus estudos. Entre os pesquisadores, cujos nomes não poderiam deixar de mencionar e às quais quero expressar todo reconhecimento, agradeço meu orientador, Prof. Dr. Norberto Luiz Guarinello, por ter me acolhido com amizade e muita competência; ao Prof. Dr. Fábio Faversani e à Profa. Dra. Ana Teresa Marques Gonçalves pela honrosa presença no decorrer do trabalho e, especialmente, pela atenta leitura e sugestões que realizaram na banca de qualificação; ao Prof. Dr. Fábio Joly e ao Prof. Dr. Pedro Paulo de Abreu Funari, por seus inestimáveis contributos ao enviar-me textos; Prof. Dr. Francisco de Fátima da Silva, pela leitura, tradução dos excertos em língua francesa, espanhola, italiana e inglesa, além da correção final da tese; ao Prof. Dr. Raúl Daniel Lavalle e à Profa. Dra. Graciela Susana Souto da Universidad Católica Argentina, por me receberem na instituição e se disporem a dialogar sobre os avanços dos estudos clássicos na América Latina e aos amigos que contribuíram com leituras e sugestões bibliográficas, particularmente, José Maria Teixeira, Paula Munhoz de Omena (UNESP/São José do Rio Preto), Elizabeth Amorin, Francisco Pinheiro (UFAC/Rio Branco), Joelma Serqueira (UFV/Viçosa), Altino Silveira Silva (UFES), José Eduardo Peixoto (USP/Ribeirão Preto) e Érica Cristhyane Moraes da Silva.

Finalmente, e muito importante, agradeço aos amigos que colaboraram, de maneira indireta para o término desta tese de doutoramento: a meus pais, Sônia e Djalma, a meu companheiro e filha, Francisco e Sophia, meus tios, Vera e Gines e Nati e Miguel, pela contínua atenção, compreensão e agradável companhia. 


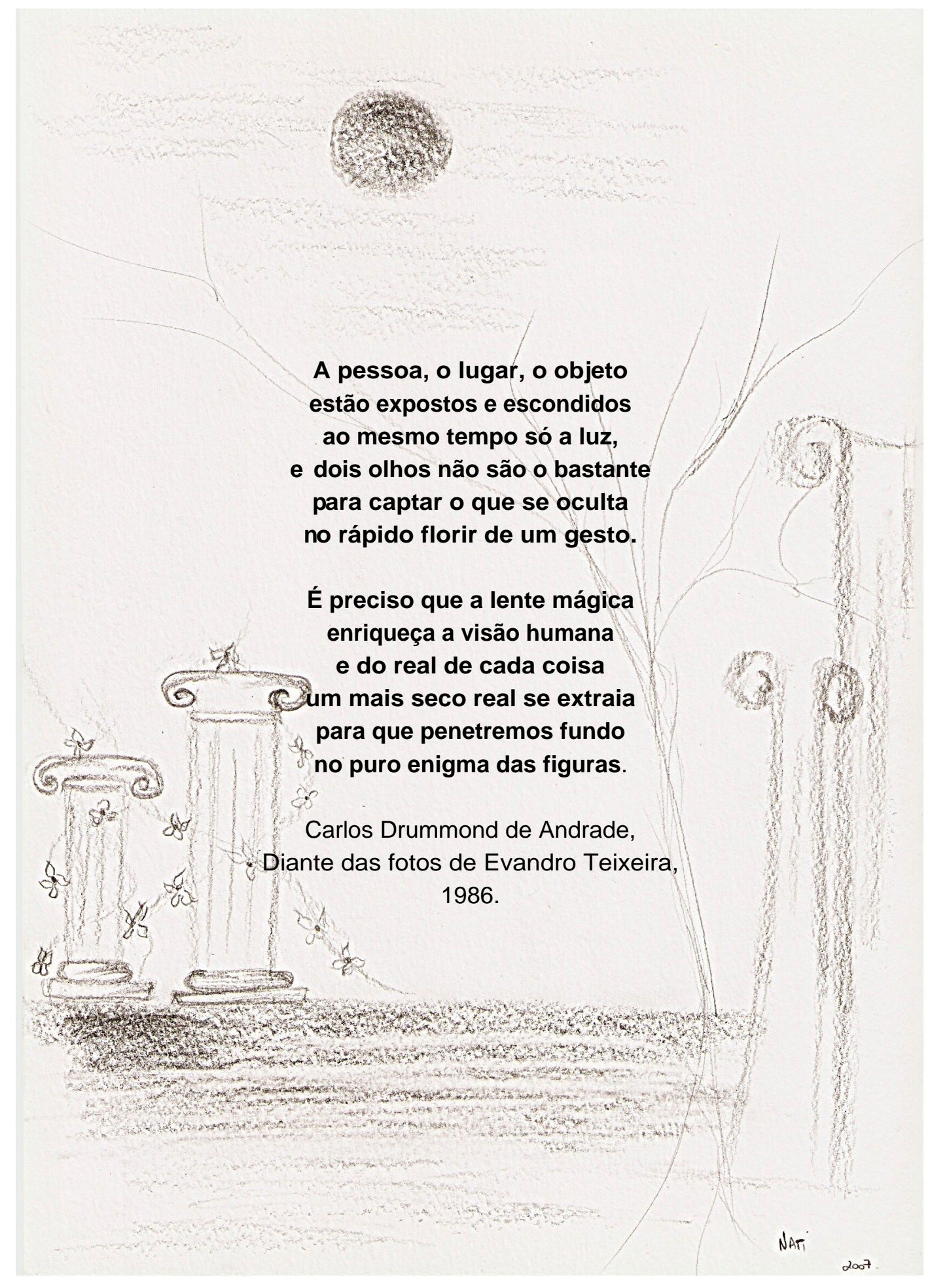




\section{RESUMO}

OMENA, Luciane Munhoz de. Pequenos poderes na Roma Imperial: o povo miúdo sob a ótica de Sêneca. 2007. Tese de (Doutorado) Faculdade de História - Universidade de São Paulo, São Paulo, 2007.

A temática do presente trabalho perpassa a discussão sobre as relações de poder estabelecidas entre os setores subalternos e seus superiores hierárquicos da sociedade romana, a partir das obras filosófica e literária de Lucius Anneus Seneca. Do ponto de vista estrutural, o trabalho dividiu-se em três partes principais: 1) $\boldsymbol{A}$ construção dos setores subalternos pela historiografia contemporânea, na qual expusemos e criticamos a construção historiográfica contemporânea de que a plebs romana seria ociosa e, sobretudo, a viabilidade de utilizar Sêneca como fonte documental; 2) A trajetória social, política e textual de Sêneca, em que analisamos o período histórico vivido por Sêneca e suas idéias; 3) A visão sóciopolítica dos setores subalternos nas obras de Sêneca, com a qual abordamos a maneira com que Sêneca construiu a imagem dos setores subalternos (e.g. ingenui, alipius, gladiator) e como desenvolviam estratégias de afirmação social com seus superiores, apresentando dessa maneira, uma realidade social muito mais conflituosa do que aquela interpretada pela historiografia.

Palavras-chave: Poder, Plebs, Roma, Sêneca, Política e Ociosidade. 


\section{ABSTRACT}

OMENA, Luciane Munhoz de. Little powers in Imperial Rome: the small people under Seneca's view. 2007. Thesis (Doctoral) Faculdade de História, Universidade de São Paulo, São Paulo, 2007.

The aim of the present study goes through the discussion on the power relationships established between subaltern sectors and his hierarchical superiors in the Roman society, based upon the Lucius Anneus Seneca's philosophical and literary composition. From a structural point of view, the work is divided in three mains parts: 1)

The construction of the subaltern sectors by the contemporary historiography, in which we introduce and criticize the current historiography construction of the Roman plebs as being idleness, and above all, the practicability of using Seneca's work as documental source; 2) The social, political and textual Seneca's career, where we analyze the epoch when Seneca lived and its assumption; 3) The social-political view of the subaltern sectors at the Seneca's composition, with which we approach the way Seneca constructed the image of the subaltern sectors (e.g. ingenui, alipilus, gladiator) and how these classes used to develop strategies for a social affirmative with their superiors, and then exposing a more conflicting social reality than that presented by the historiography.

Key-words: Seneca, Power, Plebs, Rome, Politics and Idleness. 


\section{SUMÁRIO}

PREFÁCIO

11.

CAPÍTULO I

18.

\section{A CONSTRUÇÃO DOS SETORES SUBALTERNOS PELA HISTORIOGRAFIA CONTEMPORÂNEA}

1. Panis et circenses: aplicação do conceito na sociedade brasileira 19.

2. Historiografia contemporânea e o panis et circenses 31 .

3. Relações interpessoais na sociedade imperial 42.

4. Limites e possibilidades: Sêneca como fonte documental 55.

CAPÍTULO II 61.

A TRAJETÓRIA SOCIAL, POLÍTICA E TEXTUAL DE SÊNECA

1. Contextualização Histórica: o poder imperial 62.

2. Concepção Filosófica 74.

3. Corpus documental 80.

4. Síntese das obras 82.

CAPÍTULO III 97.

A VISÃO SOCIOPOLÍTICA DOS SETORES SUBALTERNOS EM SÊNECA

1.Relações sociais: aspectos gerais 98.

1.1.Terminologia 99.

1.2. Estrutura Social 102.

2. Plebe romana e suas relações 109.

2.1. Princeps e plebs: uma relação de "mutuo" auxílio 114.

2.2. Relações de contra poderes: plebe romana 120.

2.3. Espaço público: formação de Identidade 125.

3. Escravos: entre a passividade e a reação 135.

3.1. Os micropoderes no mundo dos escravos 143.

3.2. Ofícios: fatores de hierarquização entre escravos 158.

4. Libertos: expressões de poder no Principado Romano 162.

5. Ofícios: meios de sobrevivência e estratégias de afirmação social 172.

5.1. Ofícios: artes liberais, manuais e de prazeres 174.

$\begin{array}{lr}\text { Conclusão } & 189 .\end{array}$

$\begin{array}{ll}\text { Bibliografia } & 195 .\end{array}$

$\begin{array}{ll}\text { Anexos } & 222 .\end{array}$

Anexo I 223.

Anexo II 224. 


\section{Prefácio}

Essa tese de doutoramento tem como proposta dar continuidade às reflexões levantadas no decorrer de nossa pesquisa de Mestrado. Na dissertação discutimos a idéia dominante da historiografia contemporânea de que Nero teria sido, durante os anos iniciais de seu Principado - o denominado quinquennium neronis - um soberano controlado por Sêneca (cf. WALTZ, 1909; Cizek, 1982; Petit, 1989; Canessa, 1990; Grimal, 1991)². Este defenderia, majoritariamente, os interesses do Senado e, por meio de seu aliado, Afrânio Burro, angariaria vantagens para o ordo eqüestre. Seguindo essa perspectiva, o imperador dividiria sua jurisdição legal com o Senado, proporcionando o retorno de sua antiga autoridade republicana.

Note-se que a construção da diarquia é consolidada pelo discurso de posse do jovem Nero, que traça, em linhas gerais, algumas tentativas de coibir os abusos e a concentração de poder in mano principis, pois o soberano: não determinaria todas as resoluções, seus interesses particulares não se confundiriam com os negócios da República, o Senado manteria sua antiga

1 Cabe lembrarmos que Eugen Cizek (1989) priorizava a autonomia política de Nero. Encontramos, no cerne desta interpretação, uma forte crítica a autores que posicionam o jovem monarca como um "fantoche" nas mãos de seus conselheiros, Sêneca e Burro e da mãe de Nero, Agripina. O autor não nega a forte predominância dos conselheiros, mas acentua o interesse do princeps por seus negócios, muito embora o filósofo fosse responsável pela redação de seus discursos. (p. 103). Como exemplo de dominação, Nero manteria um controle expressivo nas eleições dos magistrados, obteria benefícios ao diminuir o poder do tribuno da plebe, mesmo que encorajado pelos senadores (pp. 95-6).

Pierre Grimal (1991), diferentemente de Cizek, opta pela reconstrução de um princeps menos autônomo, mais dependente das ordenações políticas senequianas. Sêneca, segundo o autor, "devia utilizá-lo como instrumento para a conquista do poder" (p. 107). No período em que redigiu o Apocoloquintoses não foi senão o substituto de Nero. Este era, ainda, inexperiente para compor um discurso calculado, sábio e tradicional que atingisse um público ávido por uma bela linguagem (p. 110). Como agente do novo poder, Sêneca quis remodelá-lo, seguindo os passos de Augusto. Há uma promessa, nos discursos de Nero, em "reestabelecer a diarquia instituída por Augusto, a divisão de atribuições entre o príncipe, essencialmente o imperador, chefe militar, e o senado, retomando suas antigas funções administrativas" (pp. 111-112). 
função, o soberano seria responsável pelo exército e na qualidade de governante, não seria corruptível.

Esse discurso retratado pela narrativa taciteana (Tácito, Anais XIII, IV), teria sido escrito por Sêneca. Como conselheiro, pretenderia destacar, em especial, a limitação de poder do princeps na res publica. Em função disto, a historiografia contemporânea, ainda que partilhe interpretações diferenciadas, corrobora um ponto em comum: a ascendência pessoal e política de Sêneca sobre Nero proporcionariam uma aproximação do imperator com o senatus. $\mathrm{O}$ filósofo teria sido guiado pela política de Augusto, caracterizada pelo restabelecimento da diarquia. O senado, então, estaria munido por sua antiga auctoritas, quer dizer, haveria uma maior abertura política que propiciaria a legalidade, segurança e liberdade. O contributo senequiano seria, portanto, como um amicus moderador e controlador do "despotismo tirânico" de Nero. De acordo com nossa perspectiva, o filósofo da stoa, diferentemente do discurso taciteano, defende a centralização do poder político. No tratado De Clementia, por exemplo, não há referências à concessão de poder, muito menos, a sua defesa, pelo fato de o soberano ser posicionado acima das Leis e Instituições. Subordina as forças militares, a tribunicia potesta, dá-lhe o direito de interromper os processos em deliberação e garante a inviolabilidade de sua pessoa, não necessitando prestar contas a ninguém.

A clemência deve ser apreendida pelo esforço pessoal, assim, o soberano, guiado pela virtude, traz harmonia à sociedade. É quem faz o populus existir. Por isso, o mau imperador, conduzido pela tirania, tratando os cidadãos com injustiça ou punindo com requintes de crueldade, provoca um caos absoluto em todo o ordo social. Daí a clemência orientar sua própria vida, 
disciplinando seus caprichos e ambições pessoais e visa a uma finalidade única, ou seja, proporcionar um bom desempenho como chefe do imperium, cumprindo, nestas condições, suas funções como um homem sapiente e como tutor rei publicae.

Sêneca, que não consegue se imaginar fora do núcleo social, cria então estratégias de sobrevivência que privilegiam o compartilhamento de valores e se preocupa com o ordenamento e equilíbrio social (Epist. Mor. 48, 2/3). Suas críticas à sociedade se baseiam no distanciamento da razão pela falta de comedimento de seus contemporâneos (De Ira XXXV, 1).

Temos, portanto, duas preocupações no discurso senequiano que nos conduziu a análise sobre os setores subalternos da sociedade romana. A primeira se refere à política de autonomia que não liquida a negociação do soberano com os grupos sociais; mesmo estando em uma posição central, a ação do princeps deve ser controlada pela moderação. Isto implica, necessariamente, em oposição e instabilidade no poder. Daí a necessidade do soberano negociar com seus súditos, sejam aristocráticos ou não. A segunda se refere ao papel dos setores populares para a manutenção da potestas do imperator. Se, de alguma forma, a multitudo é essencial para o princeps, isto representa, por conseqüência, um elemento de relevância política, o que demonstra à atuação destes setores, comumente interpretados como apáticos e ociosos. Além disso, Sêneca demonstra certa inquietação em relação às ações individuais (e.g. escravo e liberto) que não se enquadram, nem sempre, no espaço público da política imperial.

Daí a relevância de enfocarmos, igualmente, as formas de exercício de poder de quem está submetido ao poder de outra pessoa ou grupo. Quer 
dizer, a prática de poderes dos "sem poderes" que é caracterizada não somente por revoltas explícitas, mas tudo que um subalterno pode realizar na sua relação com um superior, da adulação à rebelião. Decidimos, portanto, enfocar os agentes de posição subalterna, para mostrar que mesmo os que não têm, supostamente, poder têm seus âmbitos e poderes. Para tanto, dividimos a tese em três capítulos, a saber:

O primeiro capítulo, intitulado $\boldsymbol{A}$ construção dos agentes subalternos pela historiografia contemporânea, consiste em analisarmos o uso inconsistente do conceito panis et circenses no mundo contemporâneo por retratar a sociedade, tanto brasileira quanto romana, pela passividade. Em um segundo momento, analisamos a interpretação sobre os setores subalternos sob a ótica da narrativa historiográfica contemporânea que prioriza, em alguns casos, a negação de participação destes nas esferas social e política da sociedade romana, optando por considerar a plebe (plebs) como uma população preocupada apenas com as doações e os divertimentos. Traçaremos ainda algumas linhas sobre a interpretação historiográfica, igualmente, contemporânea que compreende a sociedade imperial por meio das relações pessoais. Além disso, enfocaremos alguns autores da historiografia brasileira, com interpretações variadas, mas que buscam compreender os setores subalternos a partir de visões alternativas, mostrandoos de forma muito mais participativa do que foi apresentado pelos autores tradicionais como Paul Veyne e aqueles vinculados aos laços pessoais de solidariedade, representados por historiadores como Andrew Wallace-Hadrill².

\footnotetext{
${ }^{2}$ Deve-se lembrar que os avanços nos estudos clássicos no Brasil e América Latina (e.g. Faculdad de Filosofia y Letras de la Universidad Católica Argentina, se interessa pelo intercâmbio de pesquisas realizadas no Brasil, apresentamos um curso e pudemos dialogar com pesquisadores como Prof. Dr. Raúl Daniel Lavalle e Profa. Dra. Graciela Susana Souto
} 
Devemos atentar ao modo como são criadas e como afetam nossas visões da História. Esta ainda retrata o eurocentrismo numa visão evolutiva da História mundial. É como se o restante do globo passasse a ter História somente após os europeus. Esta política é o reflexo das transformações contemporâneas dentro de um universo globalizante. Há uma tendência em unificar as histórias em uma única História para compreender a diversidade do mundo, seus conflitos e suas perspectivas para o futuro (cf. GUARINELLO, 2003). Queremos pontuar, sobretudo, o desenvolvimento dos estudos em Antigüidade Clássica e a produção de temas que se adequem à realidade brasileira, assim como à realidade na América Latina. Por isso, a ênfase, não apenas na historiografia européia, mas também, de forma atenta, nos estudos realizados por pesquisadores brasileiros. Por fim, esclareceremos os motivos pelos quais optamos utilizar o filósofo Sêneca como fonte documental, para compreendermos os setores subalternos da sociedade imperial.

O segundo capítulo, intitulado A trajetória social, política e textual

de Sêneca, tece alguns comentários sobre a contextualização histórica do

sobre temáticas contemporâneas e clássicas) serão mais contundentes a partir de uma política fundada no diálogo entre pesquisadores realizado em eventos como congressos, cursos de extensão, abertura às publicações e a formação de grupos de pesquisadores interessados em trabalhos temáticos que busquem, sobretudo, fugir dos modelos de compreensão histórica conservador que se definem, de modo geral, pela idéia de evolução: haveria sociedades mais, outras menos desenvolvidas e interpretações de que haveria um continuum social, quer dizer, independentemente do período histórico, encontraríamos grupos dominantes que deteriam o controle e a subjugação dos outros agentes sociais, mantendo assim, controle político e social.

Interpretação que pode, com alguma eficácia, levar governantes como o atual Presidente dos Estados Unidos da América, George W. Bush, a invadir um outro território, como foi o caso do Iraque. Utilizou o discurso de que teriam armamentos nucleares e que, portanto, poderiam invadir a soberania alheia: matando homens, mulheres e crianças. O que lhe deu legitimidade, entre tantos fatores, a concretização deste genocídio foi à utilização do discurso de que representavam à justiça e, por conseqüência, pertenciam a uma sociedade mais desenvolvida. Bush propiciaria aos iraquianos uma vida digna e sem repressão, implantando um sistema político avançado e justo: a democracia. Uma mera fábula discursiva. Primeiro por considerar o sistema cultural, político, social e econômico do Iraque atrasado, subdesenvolvido, quase uma "barbárie", se comparado ao modelo americano, em segundo, este modelo desconsidera, por completo, a diversidade de povos, culturas e organizações sociais e, por último, se pensarmos que seus interesses fundamentavam-se em questões econômicas a partir da instalação de empresas americanas para exploração da região. 
período vivido pelo filósofo e seus caminhos percorridos, tanto na esfera pública quanto na privada. Abordamos de forma sucinta o posicionamento filosófico, síntese das obras que foram incorporadas como fonte documental e a opção em não analisarmos o corpus sob uma perspectiva cronológica.

No terceiro capítulo, intitulado A visão sociopolítica dos setores subalternos em Sêneca, aborda a maneira com que Sêneca constrói a imagem dos setores subalternos e como estes se relacionam com os detentores de poder. Para tanto, dividimos o capítulo da seguinte forma: primeiramente, fizemos uma abordagem terminológica com o intuito de compreendermos os termos que se referem aos setores populares. Em seguida, estudamos as relações de poder estabelecidas entre a plebs e o princeps na esfera pública e, na esfera privada nos detivemos nas relações pessoais estabelecidas entre um superior e inferior hierárquico. Isto implica, em termos práticos, relações entre senhores e escravos, liberto e imperador, plebs e aristocracia, entre outras. No capítulo incluímos ainda uma análise sobre os ofícios exercidos pelos setores subalternos, para desconstruírmos, com isso, aquela suposição de ociosidade relatada, quase num consenso, pela historiografia contemporânea. Finalmente, apresentamos nossas conclusões gerais, procurando resumir as idéias que construímos ao longo do texto.

Termino estas considerações iniciais lembrando a poesia de Carlos Drummond de Andrade (1955) sobre a importância de refletirmos, antes de tudo, nossa sociedade contemporânea:

Não serei o poeta de um mundo caduco.

Também não cantarei o mundo futuro. Estou preso à vida e olho meus companheiros Estão taciturnos, mas nutrem grandes esperanças.

Entre eles, considere a enorme realidade. O presente é tão grande, não nos afastemos. 
Não nos afastemos muito, vamos de mãos dadas. Não serei o cantor de uma mulher, de uma história. Não direi suspiros ao anoitecer, a paisagem vista na janela. Não distribuirei entorpecentes ou cartas de suicida. Não fugirei para ilhas nem serei raptado por serafins. O tempo é a minha matéria, o tempo presente, os homens presentes, a vida presente (p. 156). 
CAPÍTULO I

\section{A OONSTRUÇÃODOSSETORESSUBAL TERNOS PELA HISTORI OGRAFI A OONTEMPORÂNEA}

\footnotetext{
"Às vezes o espelho aumenta o valor das coisas, às vezes anula. Nem tudo o que parece valer acima do espelho resiste a si próprio refletido no espelho. As duas cidades gêmeas não são iguais, porque nada do que acontece em Valdrada é simétrico: para cada face ou gesto, há uma face ou gesto correspondente invertido ponto por ponto no espelho. As duas Valdradas vivem uma para a outra, olhando-se continuamente, mas sem se amar".
}

Ítalo Calvino

Cidades Invisíveis, 1990. 


\title{
1. Panis et Circenses: aplicação do conceito na sociedade brasileira
}

\author{
Que falta nesta cidade? \\ Verdade \\ Que mais por sua desonra?. \\ Honra \\ Falta mais que se lhe ponha. \\ Vergonha. \\ O demo a viver se exponha, \\ Por mais que a fama a exalta, numa cidade, onde falta \\ Verdade, Honra, Vergonha. \\ (...) A Câmara não acode? \\ Não pode \\ Pois não tem todo o poder?............. Não quer \\ É que o governo a convence?......... Não vence \\ Que haverá que tal pense, \\ que uma Câmara tão nobre \\ por ver-se mísera, e pobre. \\ Não pode, não quer, não vence.
}

Gregório de Matos Que falta nesta cidade ${ }^{3}$

A historiografia contemporânea, desde o século XIX, como é o caso do autor alemão L. Friedländer, interpretou a sociedade romana a partir de grupos privilegiados que controlariam o acesso aos benefícios concedidos pelo poder político, excluindo, dessa forma, setores populares denominados plebs. Nesta ótica, a plebe, de uma maneira geral, nada teria a oferecer. Então, como manobra política, para a manutenção da ordem e afastá-la das decisões políticas, as autoridades davam-Ihe o pão e o circo, instaurando assim uma política do panis et circenses. Esta concepção se enraizou no senso comum de tal forma que presenciamos hoje, no público não especializado, formulações de que a plebe era sanguinária, despolitizada, ociosa e desinteressada pelo trabalho.

\footnotetext{
${ }^{3}$ Utilizamos uma publicação de 1930 das poesias de Gregório de Matos. A data de nascimento do poeta é motivo de polêmica, contudo parece ter nascido em 1633, na Bahia, e morrido em 1696. Não publicou nada em vida e somente no século XX, a Academia Brasileira de Letras publicou seis volumes, entre 1923 e 1933: I. Poesia Sacra, II. Poesia lírica, III. Poesia graciosa, IV e V. Poesias Satíricas e VI. Últimos poemas. Consultar: CÂNDIDO, Antônio. Formação da literatura brasileira. Belo Horizonte: Itatiais, 1993; BOSI, Alfredo. História Concisa da literatura brasileira. São Paulo: Editora Cultrix, 1994 e COUTINHO, Afrânio. Literatura no Brasil. São Paulo: Global, 2003(vol. II).
} 
Um exemplo disso é o filme intitulado Gladiador (2000), uma produção hollywoodiana dirigida por Ridley Scott, em que a plebe é representada como sanguinária e contagiosa diante da morte de gladiadores e animais na arena. Esta construção sugere, e aqui faço uso das palavras de Renata Senna Garraffoni (2005), "uma imagem muito forte de decadência, perversão e violência presente na mídia em geral e que acaba por formar um quadro negativo da sociedade romana" (p. 65). Interpretações, como a de Scott, constituem um ponto de vista demasiadamente preconceituoso, reduzindo a sociedade romana como aquela que copiava e deturpava a elaborada cultura grega e que tentava sufocar a nascente comunidade dos cristãos através de massacres sistemáticos.

Essa imagem negativa da cultura romana pode ser lida ainda hoje em nossos contextos políticos. Análises críticas à atual política brasileira atacam a noção do panis et circenses, traduzida no chavão: "pão e circo", característica da corruptibilidade do poder político e que estende suas raízes até mesmo em organizações, como as esportivas, que com seus campeonatos de futebol "idiotizam" a massa em comemorações. O colunista Marcelo Maroldi (2006), por exemplo, considera que em ambos os campos, o que se tem é uma versão moderna da política do pão e circo. Para o jurista Edison Vicentini Barroso (2006), o Brasil não foge à regra, pois em sua análise, vê os mais "humildes" como uma multitudo de manobra nas mãos dos "saltimbancos" de plantão, a ridicularizá-los, com ares de sabedoria e superioridade. Em sua concepção

Os festins licenciosos, em que imperam a total ausência de moral, acenam com aquela antiga perspectiva (histórica mesmo) de que tudo ficará bem, apesar do malfeito, desde que se mate a fome física e se realizem 
espetáculos circenses, pantomimas para iludir a população, tida e vista, pelos "comandantes", como palhaços a lhes atender às conveniências ${ }^{4}$.

Esse questionamento sobre a falta de comprometimento de políticos com a população brasileira é, segundo Barroso, "para que fujam ao letargo e comecem a agir, para que, no grande circo da vida, se convide a população a algo mais que palhaçadas em meio ao pão da indigestão" (idem). Estas discussões conduzem autores como Barroso e Maroldi a pelo menos três equívocos:

1. O primeiro equívoco seria, como aponta Roberto DaMatta (1993), o sentimento de indignação pelo estado de corrupção, o descaso com as políticas públicas, as relações pessoais no sistema social brasileiro e seu descompasso em relação a tudo o que as "leis constitucionais" apresentam e exigem do sistema, a luta entre o nível formal e o informal conduz autores contemporâneos a um limite de compreensão sociológica do Brasil. Como ele sugere, a chave do problema é saber até que ponto as regras formais nascidas com o mundo burguês - que estão na base do que denominamos Estado Nacional - podem englobar as regras que comandam a sociedade (cf. pp 1412).

Pode-se afirmar que as relações pessoais e as regras impessoais regem o liberalismo brasileiro e correm lado a lado em esferas sociais mutuamente exclusivas, embora complementares (cf. p. 135). Há uma combinação entre idéias liberais e o favor do sistema, quer dizer, somos liberais para certas coisas e paternalistas para outras (cf. pp. 141-2). DaMatta ainda afirma o seguinte:

\footnotetext{
${ }^{4}$ Cf.' 'LWWw.conjur.com.bir.
} 
quando se trata de comprar, vender, eleger ou ser eleito, sou universalista e demando leis e instituições confiáveis. É como se o universalismo moderno fosse demandado em público, mas o particularismo continuasse a funcionar nos planos pessoal e privado. Daí as nossas oscilações entre universalismo e particularismo, igualitarismo e hierarquia, individualismo e holismo, que parecem estar no centro dos paradoxos que enfrentamos (1993, p. 160).

O que parece notável no Brasil, parafraseando DaMatta, é a atitude social do cidadão ter uma vigência contextual negativa e igualmente relativa. Há dois níveis em que o cidadão existe: o primeiro, teórico, em que ele pode ser valorizado na letra impessoal e universal da lei e do discurso político mais acadêmico ou eleitoreiro; enquanto o outro se vincula à prática social que não o enquadra com o mesmo valor na dimensão plena de investimentos políticos, sociais e emocionais. Isto é, sentimos orgulho em sermos cidadãos em uma reunião pública, contudo, no momento que somos abordados pelo guarda de trânsito, quando necessitamos de serviços públicos de saúde ou quando somos assaltados nas ruas das grandes cidades não nos sentimos cidadãos. Temos a impressão de "que o Estado deseja sempre nos punir, humilhar ou, o que é pior, nos assaltar" (1993, p. 162).

Essa desvalorização do cidadão produz papéis individualizados e localizados, não como cidadão brasileiro com direitos e deveres, e sim como o filho, o primo, o amigo, o compadre conferindo poder imediato e personalizado. O que garante acesso, como afirmou DaMatta, "à 'consideração', ao ‘empenho', ao ‘pistolão', ao 'favor' e ao ‘jeitinho'” (DAMATTA, 1993, p. 163).

O resultado disso é que em muitas situações concretas não desejamos o título de cidadão brasileiro, pois nos deparamos com a pessoalidade. Digamos que um agente qualquer prestará um concurso público no qual o mérito será a impessoalidade medida pela comparação e competição entre os candidatos, contexto em que será julgado como cidadão. Essa 
situação seria corriqueira se não vivêssemos em um sistema com aspectos individualistas e práticas baseadas no parentesco.

Essa duplicidade ética fará com que o agente fique preocupado e desconfie que o concurso público será feito com cartas marcadas, e já se conheceriam de antemão os aprovados (cf. DAMATTA, 1993, p. 164). Como sugeriu DaMatta:

O "jeito" tem muito de "cantada" e de harmonização de interesses aparentemente opostos. O "você sabe com quem está falando?", por seu lado, reafirma a autoridade, indicando como as relações pessoais (e as práticas hierárquicas) podem, a qualquer momento, superar a lei. Pois como não saber com quem se fala numa sociedade de pessoas, onde todos se ligam com todos? (2004, p. 51)

Considerar, então, essa combinação que estrutura profundamente o Brasil como um escândalo social e político, significa renunciar muito cedo à empresa de compreender sociologicamente o país, pois todo mundo já sabe que no Brasil tudo está fora da ordem (cf. DAMATTA, 1993, p. 134).

O interessante seria, não propor descobrir que as coisas estão fora do lugar, mas compreender o lugar das coisas. Compreender a ordem de legitimidades pelas quais a sociedade brasileira articula as práticas e os valores, sempre contraditórios, que estão em jogo. Em suma, compreender o que o nosso investimento simbólico privilegia ${ }^{5}$.

2. O segundo equívoco se refere à pressuposição de que a massa é homogênea e passiva, desconsiderando, assim, o pluralismo cultural e as

\footnotetext{
${ }^{5}$ Um exemplo de seleção e investimento simbólico da tradição brasileira, utilizado por DaMatta, seria o fato de representarmos nossa identidade nacional por meio de um código racial que é para o antropólogo uma: "invenção de uma autêntica 'fábula das três raças', é uma experiência cultural brasileira que pouco tem a ver com uma possível 'história empírica' ou 'concreta' das nossas diferenciações 'raciais'” (DAMATTA, 1993 Apud FARES, 2001, p. 190). Segundo o autor, "em sociedades hierarquizadas e pessoalizadas como o Brasil, a gradação e o clientelismo diluem o preconceito que sempre pode ser visto como dirigido contra aquela pessoa e não contra toda uma etnia. Daí nossa crença em que não temos preconceito racial, mas social, o que, tecnicamente, é a mesma coisa. Numa sociedade onde somente agora se admite não existir igualdade entre as pessoas, o preconceito velado é uma forma muito mais eficiente de discriminar, desde que essas pessoas 'saibam' e fiquem no seu lugar' (DAMATTA, 2004, p. 26).
} 
tensões sociais. Esta homogeneização não corresponde à realidade contemporânea e, nem mesmo, à romana, em relação à aristocracia. Considerar a formação social a partir de binômios elite e massa, superior e inferior ou mesmo elite e subalterno ${ }^{6}$ é inconsistente por três motivos: primeiro, restringe a posição social dos agentes na sociedade; segundo, ignora as dimensões dos micropoderes e; terceiro, não leva em consideração o modo como se organizam os agentes sociais.

Esses conceitos utilizados pela historiografia para compreender as formações sociais não abrangem em sua diversidade todos os agentes de uma dada sociedade. As variedades regionais, econômicas, sociais e culturais no Brasil são responsáveis, por exemplo, pela determinação de elites com maior ou menor poder político ou econômico. Assim como a cotidianidade de um operário em Santa Catarina, se comparado com um outro no Acre, será diversa. Se pensarmos no espaço geográfico, um tipo de trabalho como o de carvoeiro ou seringueiro, ou ainda a música, a dança, o predomínio de

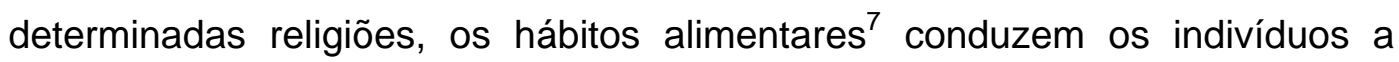
diferentes experiências no cotidiano, embora tenham a mesma língua e o

\footnotetext{
${ }^{6} \mathrm{O}$ termo subalterno origina-se do prefixo latino sub, que significa baixo e inferior. Como podemos observar, o conceito subalterno é sinônimo, na língua portuguesa e latina, de subordinado, dependente, inferior e secundário, cuja origem provém do prefixo em Latim que significa inferiorização. A utilização do termo "subalterno" não implica que estes indivíduos ou grupos sejam desqualificados, menores ou submissos ou que queiramos restringir sua(s) heterogeneidade(s), mas apenas salientar e classificar o que é essa "não elite" para Sêneca. Consultar obra de referência: MACHADO, José Pedro. Dicionário etimológico da língua portuguesa. Lisboa: Confluência, 1967 e SARAIVA, F. R. dos Santos. Dicionário latinoportuguês. Rio de Janeiro/Belo Horizonte: Garnier, 1993.

5 DaMatta (2004) fez um estudo interessante sobre o hábito alimentar no Brasil, indicando, dessa forma, as diversidades regionais e a diferenciação entre comida e alimento. Em sua proposta, é preciso indicar "como a culinária brasileira privilegia os cozidos - das peixadas às feijoadas, passando pelas moquecas e rabadas, sem esquecer o pirão, os guisados, os mexidos, as dobradinhas e as papas. Temos, sem dúvida, especial predileção pelo alimento que fica entre o líquido e o sólido, permitindo, como ocorre com o modesto arroz-com-feijão, a congregação, a relação, o mulatismo e a mistura (...) Temos uma culinária relacional a falar de uma sociedade também relacional" (p. 35).
} 
mesmo sistema político. Há infindáveis brasilidades entre o chimarrão e o tacacá ${ }^{8}$. Trata-se de compreender o Brasil pelas

instituições formais como o Estado, a constituição, o mercado, o dinheiro, quanto ao país do jeitinho, da comida, das relações étnicas, da mulher, da religião. Dos jogos espertos e vivos da malandragem e do carnaval, onde podemos vadiar sem sermos criminosos, experimentando a sublime marginalidade que tem hora de começar e de terminar (DAMATTA, 2004, p. 08).

Assim também a sociedade romana não era apenas formada por elites dependentes da posição central ou periférica das províncias, mas até mesmo os escravos, como veremos no capítulo terceiro, hierarquizados pelo tipo de ofício e a constituição de elites entre os pobres. Encontraremos, dessa forma, uma dimensão variada de organização e de poder com relação a cada agente ou grupo social no mundo romano.

Uma proposição dominante hoje em dia é a forjada por Géza Alföldy (1989), isto é, as camadas superiores se protegiam por pertencerem a "uma organização corporativa, de tal modo que era possível o controle da admissão e da qualidade de membro dessas ordens, mantendo-se assim rigorosamente a hierarquia da organização social” (p. 126). Por um lado, a homogeneidade da elite representaria um sistema fechado, com raríssima mobilidade social. Por outro lado, a sedimentação da plebe seria uma categoria produzida a partir de uma diversificação de grupos, sem grande expressão social.

Essa perspectiva de que a homogeneidade garantiria uma maior estabilidade social e, portanto, um maior conhecimento sobre a estrutura social

\footnotetext{
${ }^{8} \mathrm{O}$ tacacá é uma espécie de sopa (servida em cuias, acompanhadas ou não com molho de pimenta de cheiro) preparada com tucupi (suco de uma espécie de mandioca, previamente fervido com alho e chicória), camarões secos, goma (mingau feito com uma massa fina e branca, resultado da lavagem da mandioca ralada) e jambú. O chimarrão é uma erva-mate servida em cuias, sem adição de açúcar e preparada com água morna. Normalmente é uma bebida tomada em conjunto, passando de um para outro e encontra-se em diversas regiões do Sul do Brasil e da América Latina.
} 
dos agentes é uma fábula. Se pensássemos nessa dimensão, como compreenderíamos o universo romano e brasileiro? Como compreenderíamos a formação das identidades regional e global? Estas são, segundo DaMatta (2001), categorias exclusivas e possuem dimensões sociais que remetem a "duas humanidades distintas, cada uma das quais tendo suas vantagens e os seus inconvenientes particulares, os bens e os males que lhes são próprios" (p. 169 Apud TOCQUEVILLE, 1977, p. 541) ${ }^{9}$.

Essa dimensão local e global, discutida por DaMatta, é aplicável igualmente à História do Império Romano. Levando-se em consideração a constituição do Império como um pluralismo cultural, podemos questionar, como no caso de nossa pesquisa, qual era a plebe pensada por Sêneca, provincial ou de Roma? De acordo com o corpus documental, veremos que o filósofo ora se referia à cidade de Roma, ora, às províncias. Julgamos este questionamento imprescindível, pois tendemos a nos referir historicamente à cidade de Roma como se nos referíssemos à História Romana, isto é, utilizamos aspectos específicos de uma determinada região como se falássemos do todo. As regiões no Império abrangiam experiências em tipos e

9 DaMatta (2001) questiona a utilização do conceito de globalização levando-se em consideração a experiência brasileira, para a partir daí, compreender a formação da identidade global e local. Damos voz ao autor: "pergunto-me se não é precisamente nessas situações de irresistível globalização que ficamos conscientes de nossa singularidade e da nossa identidade. Quer dizer, é justamente na incômoda desorientação e impessoalidade do espaço de um aeroporto que tenho a inquietante sensação de ser brasileiro. $E$ de ser brasileiro carente precisamente de "gente", de "calor humano", "de pessoas com quem conversar". O fato de poder comer pizzas em Chicago, Manaus ou Nova Déli talvez acentue ainda mais o caráter arbitrário e impositivo desse universalismo que, certamente, disfarça a força opressora dos grandes centros de prestígio e poder (p. 177). Segundo a proposta de DaMatta, deve-se investigar "os pontos de encontro - ou relações - entre as representações dos fenômenos globais e a constituição dos valores locais. Pois nem o global, com sua força normativa e sua aura como agente do progresso, nem o local, cercado de estigmas e lido como fonte de atraso, podem ser subestimados em suas representações e em seus pesos relativos na consciência social dos agentes" (p. 174). Isto porque, como demonstra DaMatta, "verifica-se uma polarização entre o universal e o local. É verdade que as sociedades fechadas e grupos tradicionais estão expostos a mensagens multiculturais, mas isso não significa que eles dancem de acordo com a mesma música, nem que mudem de acordo com a receita. Muito pelo contrário, a universalização crescente e imposta pela ausência de um outro lado implica uma necessidade premente de autodefinição e, acima de tudo, de autoconhecimento" (p. 178). 
níveis diferenciados como a cultura e a língua. Altera-se, então, a maneira com que os agentes sociais se interagiam em cada localidade. Consideramos crucial o questionamento de Norberto Luiz Guarinello (2003) sobre os estudos da História de Roma. Damos voz ao autor:

Império? E as outras cidades, porque permanecem fora da História? Nada acontecia nelas enquanto Roma, voluntaristicamente, acumulava poder? Ora, a História de Roma, como cidade, só faz sentido se pensarmos que existia um mundo de cidades e que sua expansão se deveu, não tanto a força de uma vontade peculiar, mas as fraquezas e necessidades estruturais desse mesmo mundo (pp. 53-4) ${ }^{10}$.

3. O terceiro equívoco cometido por autores contemporâneos é reproduzir a imagem do poder político no império romano sob o estigma do pão e circo. Interpretar a prática do poder romano a partir de um grupo socialmente privilegiado que conduzia como bem queria uma massa amorfa e apática que se reproduzia em seu continum histórico podendo, assim, ser também identificada à sociedade brasileira, é uma postura, pelo menos do ponto de vista empírico, equivocada. Se analisarmos a visão senequiana sobre os agentes da sociedade romana, veremos que, mesmo aqueles que estavam em condição subalterna e que não tinham supostamente poder se relacionavam e

${ }^{10}$ Guarinello (2003) analisa ainda, com muita propriedade, as incongruências conceituais de História Antiga. Segundo ele, "as incongruências conceituais da História Antiga não se restringem ao que poderíamos chamar de seu conteúdo ideológico. Há outras incoerências em seu interior. Há outras formas dentro da História Antiga. Em muitos países como o Brasil, História Antiga é ensinada e pesquisada dentro de três divisões principais: Antigo Oriente Próximo (principalmente Egito e Mesopotâmia), Grécia e Roma. É deste modo que a História Antiga aparece nos livros didáticos, e assim é estruturada uma grande parcela da pesquisa acadêmica (ainda que não toda). Esta divisão tripartite é apresentada ao público em geral na forma de sucessão cronológica, como se a tocha da História, na corrida de revezamento que é o progresso da humanidade, tivesse sido transmitida progressivamente de Leste a Oeste. Como se a História se apagasse progressivamente a Leste, para reacender-se a Oeste, à medida que o foco da civilização se deslocava" (p. 52). Ainda segundo Guarinello, "um segundo problema diz respeito à diversidade de critérios desta divisão tripartite. Em termos conceituais, ela é bastante incongruente. O Oriente Próximo é uma partição geográfica, definindo um vastíssimo espaço territorial, mas não, necessariamente, tipos de sociedades e culturas específicas. Nenhuma unidade essencial marca a longuíssima História do assim chamado Oriente Próximo e sim, muito pelo contrário, uma grande diversidade de povos, culturas e organizações sociais" (p. 53). 
negociavam a seu modo com os de posição superior. Tinham, portanto, seus âmbitos e poderes.

Assim é com a ação de indivíduos ou grupos sociais no Brasil, considerados marginais ou não, a exemplo do tráfico organizado, que transformam o cotidiano das pessoas nos centros urbanos. A ação concatenada de presidiários com indivíduos do tráfico contra as autoridades estatais, ocorrida em maio de 2006, em especial em São Paulo, demonstra, muito claramente, que o poder se constitui por diferentes ramificações, que não partem necessariamente nem do centro, nem da periferia. Pode-se dizer que o "poder é algo que se exerce, que se efetua, que funciona" (MACHADO, 1986, p. xiv). Funciona como uma máquina social que não está situada em lugar privilegiado ou exclusivo, mas se dissemina por toda a estrutura social. $\mathrm{O}$ poder é uma prática e se estabelece por um mecanismo de atuação em que todos os agentes sentem seus efeitos, suas relações, seus variados dispositivos que se articulam e se exercem em níveis diferenciados da sociedade, em domínios e em variadas extensões (cf. FOUCAULT, 1986).

Concluiremos a discussão, ressaltando dois elementos: em primeiro lugar, o uso inconsistente do conceito panis et circenses no mundo contemporâneo por retratar a sociedade, tanto brasileira quanto romana, pela passividade. Interpretá-la pelo viés da harmonia é desconsiderar o caráter conflitivo e a formação multicultural da dinâmica social. Não pretendemos, com isso, desenvolver comparações entre as sociedades brasileira e romana, embora seja possível. Como sugeriu J. A. Trabulsi Dabdab (2001), podemos realizar uma homologia, um parentesco "entre duas épocas que não têm 
relação de influência uma sobre a outra, que não têm sucessão cronológica, nem sucessão lógica e direta e nem mesmo indireta" (p. 77).

Em segundo lugar, enfatizamos a utilização equivocada do chavão pão e circo, para compreender sociologicamente os estados de corrupção no poder político e de agentes privados. As trocas de favores, manipulação de resultados em campeonatos de futebol, nepotismo, quebra de decoro parlamentar, clientelismo ${ }^{11}$ que encaminham o estado brasileiro à falência, situação que se reflete na educação, saúde, falta de moradia, trabalho e é intensificada com a má distribuição de renda. Isso tudo, aliás, faz com que o cidadão brasileiro tenha uma única exigência:

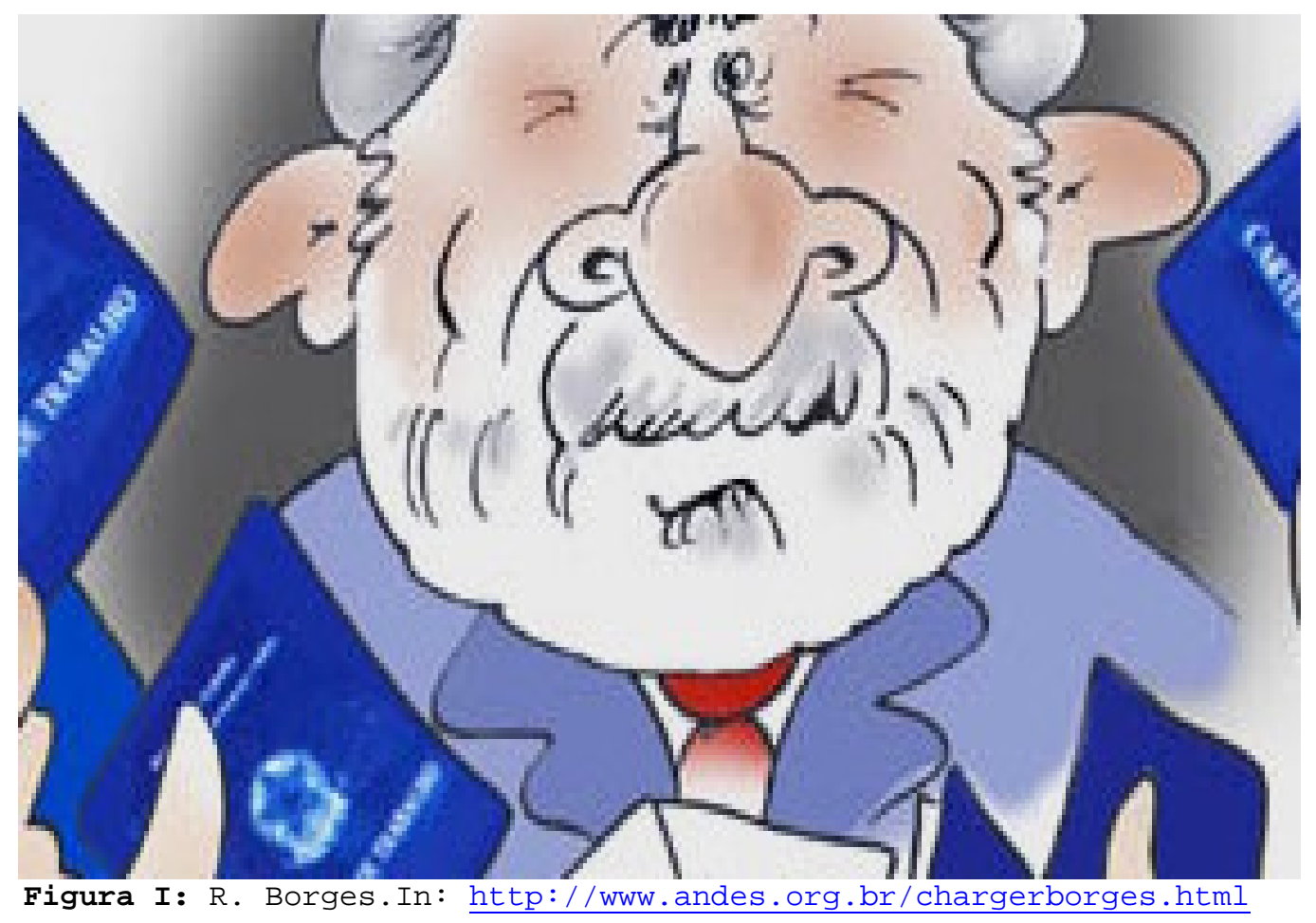

\footnotetext{
11 Temos inúmeros exemplos de escândalos de corrupção entre senadores e deputados federais e estaduais, citaremos apenas um: Severino Cavalcante, Ex. Presidente do Congresso e da Câmara, renúncia ao cargo de Deputado Federal, após a comprovação de ter recebido propina do empresário Sebastião Augusto Buani, dono do grupo Fiorella, para que continuasse com a licitação de seu restaurante no congresso.
} 
Terminada essa introdução, discutiremos a visão historiográfica contemporânea sobre os agentes subalternos da sociedade romana imperial. Dividiremos a argumentação da seguinte maneira: em primeiro lugar, examinaremos de forma minuciosa como a historiografia tradicional aplicou 0 conceito de pão e circo aos setores populares, delegando-os um papel secundário na História Romana; em segundo, analisaremos a opção de interpretar a sociedade pelas relações interpessoais, enfocando seus avanços e limitações e; por último, apresentaremos os motivos pelos quais utilizamos as obras de Sêneca como fonte documental. 


\section{Historiografia contemporânea clássica e o panis et circenses}

No fundo, somos bárbaros no sentido de
que usamos os bens, mas não conseguimos
pensá-los".

Alfredo Bosi
Cultura brasileira: tradição/contradição, 1987.

Dada a relevância do tema para as discussões contemporâneas e o estudo em Antigüidade Clássica, analisaremos as abordagens do panis et circenses. Trataremos, primeiramente, das pressuposições do historiador Friedländer (1947). Este, em meados de 1862, escreveu uma obra de grande fôlego - Darstellungen aus der Sittengeschichte Roms in der Zeit von August bis zum Ausgang der Antonine ${ }^{12}$ - sobre o Império Romano, enfocando diversos aspectos da vida econômica, social, política e cultural da sociedade romana.

Friedländer interpretou a sociedade enfocando três elementos estruturais: a corte, as três classes e o terceiro estado. A primeira composta pelos amigos do princeps, os funcionários e os servidores, ocupou, de forma gradativa, um espaço relevante em quase todo o primeiro século. O princeps utilizava libertos e escravos em serviços pessoais ou funções administrativas em seus negócios ou instituições, não havendo uma distinção muito clara entre administração imperial e casa imperial.

Para ele, a existência de indivíduos de extratos subalternos na casa e na administração imperial ocorria pelo fato de o princeps resistir à

\footnotetext{
${ }^{12}$ A primeira edição foi publicada nos anos de 1862 e 1864 com o título Cuadros de historia de las costumbres romanos desde Augusto hasta el final de los Antoninos. Utilizamos a tradução em língua espanhola que se baseou na última edição alemã, publicada em 1934, publicada pela Phaidon (Viena), que reproduz, o texto íntegro da décima edição.
} 
aristocracia, demonstrando sua capacidade por caprichosa que fosse, de converter homens humildes em homens poderosos (cf. p. 38). $O$ autor pressupõe que o acesso ao poder de libertos ou escravos dependia de suas relações pessoais com o imperator e não da capacidade destes articularem e negociarem sua posição na estrutura social (cf. p. 45) ${ }^{13}$.

Assim como nas três classes, senadores e cavaleiros que possuíam status social elevado na sociedade romana deveriam possuir riquezas e boas relações para alcançarem postos superiores e ostentarem a dignidade no Estado. Os libertos marcavam sua ostentação pelo adorno nas ruas de Roma e em outras cidades e pela construção de suntuosos edifícios. De acordo com Friedländer, "descobriram-se, em distintos lugares, inscrições com nomes de libertos imperiais como construtores de templos, termas e outros grandes edifícios" (p. 51). Ainda que pudessem ostentar sua uirtus que consistia na riqueza e no poder, os libertos viviam sob o estigma da escravidão; eram expostos a diferenciações entre ingenui e libertos, por direito ou amizade (cf. p. 108).

Ainda segundo Friedländer, a condição dos proletários era ainda mais desoladora, pertenciam ao terceiro estado e exerciam ofícios de comerciantes, barbeiros, professores, artesãos entre outros, vivendo em torno do pão e do circo, que ocorria mediante uma emigração incessante atraída das províncias à capital pelos benefícios concedidos (cf. p. 164). Segundo Friedländer, os benefícios eram oferecidos aos indivíduos masculinos e

\footnotetext{
${ }^{13}$ Friedländer influenciou análises contemporâneas como as de Wallace-Hadrill, Richard Saller, Peter Garnsey e Duncan Cloud que privilegiam as relações pessoais com o imperador, cuja função estaria na obtenção de privilégios, benefícios e poder. Duncan Cloud (1990) afirma existir "evidências suficientes para mostrar que Roma não era diferente de muitas outras sociedades ao excluir os que eram muito pobres das relações cliente-patrono; ainda que a relação fosse assimétrica, o cliente tinha que estar apto a contribuir com algo e, sob o Império, os cidadãos muito pobres não tinham nem o voto a oferecer" (p. 210).
} 
cidadãos por viverem em estado de pobreza e miséria, embora as distribuições públicas de trigo fizessem parte de um sustento elementar.

A distribuição ocorria juntamente com os espetáculos e os jogos gladiatoriais que eram, inicialmente, religiosos na República, enquanto, no Império, passam a ter uma conotação política. Os espetáculos serviam, essencialmente, para ganhar o favor do público e aplacar a sede de violência, predominante da multitudo (cf. pp. 497-8) ${ }^{14}$. Prevaleciam, segundo Friedländer, na população da cidade de Roma:

massas despossuídas, uma gentalha brutal, grosseira e corrompida, se comparada às capitais modernas, pois em nenhuma parte, nem em nenhuma época do mundo, chegou a concentrar a luz de todas as nações como na Roma de então, uma vez que era, duplamente perigoso, pois estava formada, em grande medida, por pessoas ociosas. O governo cuidava de seu sustento mediante as grandes distribuições periódicas de trigo e, como conseqüência, via-se obrigado a cuidar de seu tempo livre, oferecendo distrações para entreter a sua ociosidade (p. 498).

Como podemos observar, Friedländer expressa, em suas análises

históricas, valores morais incutidos em conceitos como "gentalha", adjetivados por "massa brutal", "corrompida" e "desocupada"15. Como propôs Garraffoni

${ }^{14}$ Essa opção em interpretar os jogos gladiatoriais como espetáculos sangrentos influenciou autores como Hibbert (1988) que reproduziram perspectivas de que o público se satisfazia e exigia a violência, o incesto, à pilhagem e o canibalismo (cf. p. 54). Garraffoni (2005) em um estudo atual sobre os gladiadores na Roma Antiga faz críticas à construção da violência nos jogos na arena - critica autores como M. Grant (1960), M. Wistrand (1990). Utilizando fontes literárias e arqueológicas a autora afirma que a violência foi enfatizada em fontes literárias como Sêneca e Tácito. De acordo com suas palavras, Tácito acentua: "tanto na maneira como organiza seu discurso, escolhendo termos que intensificam e dramatizam as mortes, assim como nas atitudes dos que participaram da rixa, pois estes carregavam pedras e espadas, postura que muitos estudiosos afirmam não ser comum entre os espectadores. Se por um lado há uma ênfase na violência, por outro, a punição também aparece com força em seu relato. $O$ julgamento em Roma, a proibição dos espetáculos por dez anos, a dissolução dos collegia e a punição dos organizadores, acusados de incitar a desavença, são aspectos que não passam despercebidos na narrativa de Tácito" (p. 138).

${ }^{15}$ Contemporâneo de Friedländer, Mommsen (1983) propõe, de forma menos explicita, que a plebe era ociosa o que causava desinteresse pelo trabalho. Citemos in extenso: "O plebeu romano preferia estar horas inteiras olhando com a boca aberta o teatro a trabalhar; as tavernas e os lupanares eram tão freqüentados que os demagogos exploravam, o seu gosto, os proprietários destes estabelecimentos para o seu proveito. Os jogos gladiatoriais, que revelavam e nutriam a mais espantosa desmoralização do mundo antigo, eram negócios tão florescentes que, somente com a venda de seus programas, poderia realizar-se consideráveis fortunas e neles se introduziram, nesta época, uma horrível inovação que não era a lei do 
(2005), o historiador imprimiu tais valores à sociedade romana, em especial, vendo os setores populares dentro de um contexto capitalista que valorizava o trabalho e via o otium como uma ameaça à ordem estabelecida.

A própria maneira como o pesquisador alemão compara os marginalizados romanos com os modernos e considera os primeiros mais perigosos por constituírem uma maior quantidade de pessoas ociosas. Assim, embora empregue a mesma palavra latina, seu significado é outro, uma vez que indica mais uma preocupação moderna com o desemprego e as revoltas que acometiam as cidades deste momento que o conceito em si (p. 72).

Essas considerações sobre a despolitização, ociosidade e violência da plebe foram reproduzidas pela historiografia do século XX. Temos inúmeros exemplos: J. Carcopino (1942) ${ }^{16}$, Gagé (1964), Rostovtzeff (1967), Veyne (1976), Alföldy (1989), Petit (1942), Robert (1995), Grimal (1995) entre outros.

A obra Roma no apogeu do Império, escrita por Carcopino, contém reflexões sobre a vida na urbs, seu esplendor expresso em edifícios públicos e casas aristocráticas, as ruas expondo suas misérias, a atuação da mulher frente à sociedade, ofícios, educação, espetáculos gladiatoriais entre outros aspectos. Carcopino (1990) apresentou, no entanto, a dinâmica social baseada em uma posição binária: elite e plebe. Para ele, a elite representava sabedoria, riqueza e poder, simbolizados pelas grandes construções públicas e pela domus. A plebe, pelo contrário, empobrecida, desocupada e propensa a revolta era apaziguada pelos césares romanos que não a deixavam sentir fome e tédio. Os espetáculos tornavam-se diversões para a ociosidade dos súditos e

duelo em que o vencedor decidia pela morte do vencido, mas sim um capricho dos espectadores, que por meio de um sinal, o vencedor perdoava ou atravessava com a espada o derrotado estendido a seus pés. O ofício de gladiador havia subido tanto quanto havia baixado o preço da liberdade, que a temeridade e a coragem, tão ausentes dos campos de batalha nesta época, brilhavam esplendorosamente entre os combatentes da arena, onde a lei do duelo exigia que o gladiador se deixasse matar sem tremer ou exalar um gemido, sendo além disso, feito freqüente o caso de um homem livre se vender ao empresário do circo como escravo gladiador pela comida e dinheiro (p. 41 Apud GARRAFFONI, 2005, p. 67).

${ }^{16}$ Utilizamos a seguinte tradução: CARCOPINO, J. Roma no apogeu do império. Prefácio de Raymond Bloch e Tradução de Hildegard Feist. São Paulo: Companhia das Letras, 1990. 
um instrumento seguro de seu absolutismo (cf. p. 329). De acordo com suas

palavras:

150.000 proletários alimentados pela Anona às expensas do Estado: desocupados e eternamente sem trabalho, satisfeitos com esta situação, reduziam seus esforços em perceber, um dia de cada mês, os víveres que gozariam até a morte (1990, p. 270).

Percebemos nos traços desenhados por Carcopino o cotidiano de uma plebe excêntrica e sem atividade, vivendo das diversões sangrentas oferecidas nos combates gladiatoriais ${ }^{17}$. Como sustentou Garraffoni (2005), a inovação de Carcopino, em relação aos seus colegas precedentes,

está no argumento que segue o desenvolvimento de seu texto, isto é, este quadro caótico e sanguinolento só viria a melhorar no final do Império com a chegada do cristianismo, religião que salvaria o povo desta vida profana, nefasta e violenta (p. 73).

Na década de 80, Jean-Noël Robert (1995) publica Les plaisirs à $R_{0 m}{ }^{18}$, enfocando, assim como os autores anteriores, a política do pão e circo como instrumento de dominação dos aristocratas. Em um trecho, o autor comenta que

os jogos e as redistribuições frumentárias são dois alicerces da política imperial. Diverte-se a multidão que exige o sensacional. Paradas, encenações de grandes espetáculos, a morte de homens ou de animais

\footnotetext{
${ }^{17}$ A proposta de Gagé (1964), semelhante a Carcopino, retratava a plebs como indivíduos sem recursos e, por este motivo, podiam apenas representar o papel de clientes parasitas em torno de um grande personagem, neste caso, o princeps (p. 125). Rostovtzeff (1967) não foge à regra, na obra História de Roma, afirma que "os membros inferiores eram escravos ou semilibertos, sem esperança de promoção à classe superior, embora houvesse exemplos ocasionais disso, especialmente durante o reinado de Cláudio" (p. 234). Sem promoção social, viviam do abastecimento regular e abundante de alimentos, da distribuição gratuita de pão, dos divertimentos em locais amplos como teatros, banhos públicos, basílicas, praças e jardins; locais desfrutados pelas camadas mais baixas com as mesmas vantagens de conforto e ordem que estavam ao alcance dos ricos (p. 245). Segundo o autor, cerca de 200.000 pessoas, das classes mais pobres, eram mantidas pelo Estado e as demais podiam encontrar trabalho em abundância, se o desejassem. O que fica implícito no discurso de Rostovtzeff é que há trabalho em abundância e pouca vontade de exercê-lo. Citemos in extenso, "as demais podiam encontrar trabalho em abundância, se o desejassem. Não havia falta de distrações, especialmente no governo de Nero, Domiciano e Cômodo; ocasionalmente, eram feitas doações ao povo em dinheiro ou em bens" (p. 242).

${ }^{18}$ Essa obra foi publicada no Brasil com o título Os prazeres em Roma. Tradução de Marina Appenzeller. São Paulo: Martins Fontes, 1995.
} 
são os lotes cotidianos de um público que pede para ser enfeitiçado. Os próprios monumentos das cidades, termas, teatros, anfiteatros, circos contribuem para o que Sêneca chama 'servidão ociosa das cidades' ( $p$. 38).

Essa pressuposição de que a multitudo exigia e necessitava ser "enfeitiçada" nos grandes espetáculos estaria presente, segundo o autor, em fontes literárias como as de Sêneca, Juvenal, Horácio, Cícero, entre outros e nas fontes arqueológicas como as pinturas parietais de Pompéia. Em termos gerais, Robert (1995) analisa os prazeres cotidianos da sociedade romana que são caracterizados e diferenciados pelas seguintes oposições: "povo" e rico, coletivo e particular, cotidiano e ocasional, cidade e campo e, por último, homens e mulheres (cf. p. 15). Esta proposta é inicialmente interessante e instigadora. No entanto, o caminho trilhado pelo autor o leva a reproduzir alguns conceitos da bibliografia mais antiga. Vejamos:

1. O texto revela apreciações morais identificadas por palavras pejorativas como "povinho" ou interpretações que marginalizam os setores "ditos populares", considerando-os devassos, ociosos, preguiçosos e por preferirem os jogos suntuosos a trabalhar (p. 40). Bairros como a Suburra são descritos como locais onde perambulam, por toda a parte, "marginais, escravos em fuga, malfeitores de todos os tipos coabitavam com pequenos comerciantes na miséria, sapateiros, ferreiros, tecelões e cabeleireiros" (p. 47). Nestes bairros povoam, dessa forma, por uma infinidade de "prazeres suspeitos, superpopulação, miséria, violência, ruelas da Roma dos pobres são palcos de uma luta incessante contra a morte, opressão e doença" (Ibidem).

Segundo a leitura de Robert, a cidade de Roma, no período imperial, tornara-se "parasitária, livre para se entregar aos prazeres mais voluptuosos" (p. 38), diferentemente da Roma Arcaica que se fundamentava na pobreza e 
na virtude. O historiador apresenta uma perspectiva tradicional em que o campo é o espaço de sabedoria e a urbs é o campo de luxúria e devassidão. Apresenta-nos quase uma visão apocalíptica, em que o cristianismo aparece como doutrina para moralizar aquela sociedade decadente. Citemos in extenso:

O fato de esses dois homens [Amiano Marcelino e o apóstolo João], de uma cultura fundamentalmente diferente, mas engajados da mesma maneira numa luta contra a depravação terem chegado a conclusões tão negras comprova suficientemente que, além de qualquer exagero, Roma atravessava uma crise moral cuja amplidão permitiria que o cristianismo fosse ouvido (ROBERT, 1995, p. 41) ${ }^{19}$.

2. A segunda linha interpretativa do autor se baseia na simples oposição entre rico e pobre, perdendo-se, dessa forma, o caráter heterogêneo da sociedade romana e como afirmamos anteriormente, a capacidade de compreensão dos micropoderes e a maneira com que os grupos ou indivíduos se organizam e se estruturam nas esferas sociopolíticas.

19 Tanto Grimal quanto Carcopino e Robert apresentam sob o rótulo de povo todos os segmentos populares como bandidos, gladiadores, escravos, libertos, pobres. Os competidores dos jogos gladiatoriais eram bandidos e escravos, que divertiam o povo ocioso e predisposto aos espetáculos sangrentos. Para Grimal (2001), "nessa época [a de Nero], os jogos tinham-se tornado uma necessidade política, uma maneira de o Imperador ocupar os tempos livres da plebe urbana e satisfazer, melhor ou pior, os seus instintos de violência" (p. 212). Segundo Grimal (1995), essa ociosidade organizou-se, desde o século II a.C., a partir de "uma verdadeira assistência pública, consistindo na distribuição de trigo, vinho e azeite a baixos preços e, por vezes, gratuitamente. É assim que se começava a esboçar, a partir dos últimos anos do século II a.C., a fisionomia do que será a plebe imperial, parasita de um Império que ela não conquistou, não preocupada com o dia seguinte, mas pronta para os tumultos sangrentos, instrumento dócil para a palavra dos oradores populares e dos demagogos" ( $p$. $57)$.

Os espetáculos que exigiam mais inteligência eram menos apreciados, preferiam espetáculos sangrentos à incumbência de pensar com as peças teatrais. De acordo com as palavras de Grimal (2001): "não atribuamos as culpas a uma qualquer estupidez particular da raça humana: os espetáculos que apelam para a inteligência sempre tiveram menos admiradores do que aqueles que satisfazem os instintos profundos e mais elementares, muitas vezes em detrimento da simples decência" (p. 216). Autores como Florence Dupont (2003) discordam desse tipo de análise de que o romano não apreciava o teatro. Citemos in extenso: "O público romano não é inculto e grosseiro sob o pretexto de que não se interessa por literatura, sua cultura é diferente daquela dos espectadores atenienses dos séculos V e IV. Esta diferença se resume em uma fórmula: Atenas era a cultura da palavra e do julgamento, Roma a cultura da música e da percepção imediata (...) A plebe apreciava o teatro no momento do espetáculo e não em um momento literário" (p. 114). 
Aliado a isso, a categoria "povo", utilizada abundantemente por Robert bem como por Sêneca, conduz o leitor a defini-la por plebe, pois como veremos no capítulo III, o termo populus é uma categoria rica que admite diferentes significados e variações. Um exemplo disto é a utilização da seguinte passagem das Epistulae Morales:

Virtude, filosofia, justiça, palavras vazias e ruidosas! A única felicidade é festejar a vida; comer, beber, gozar plenamente, isto é viver, é não esquecer que somos mortais. Os dias passam, a vida completa seu curso irreparável. E hesitamos? De que serve ser comportado e como nem sempre nossa idade será própria para os prazeres, infligir-lhe a temperança - quando ela pode usufruí-los, quando ela os exige - e por aí antecipar a morte; e tudo o que a vida deve carregar, a partir de hoje aniquilá-lo para seu uso? Não tens amante, nem namoradinhos para despertar ciúmes em tua amante; todos os dias sais com a garganta seca; teus jantares são os de um filho que tenciona submeter suas contas diárias a seu pai! Isso não é viver, é olhar o outro viver. Que loucura constituir-se o intendente de seu herdeiro! (Sêneca, Epist. Mor. Apud. ROBERT, 1995, p. 07)

Robert (1995) quer demonstrar, através do excerto senequiano, a prática dos prazeres populares no universo cotidiano como sinônimo de plebe. Sugere implicitamente a oposição plebe e elite, afirmando que o povo não seria capaz de uma ascese intelectual, se comparados à moral e à instrução de Sêneca e Lucílio, homens que sabiam dominar seus instintos (p. 07). Sêneca, pelo contrário, reprovava os indivíduos - nesse excerto - que não se guiavam pela filosofia estóica e não um segmento social em especifico. Por isso, afirmamos que o significado "povo" dependerá da contextualização apresentada na narrativa senequiana.

Como podemos perceber, a historiografia contemporânea, fundamentada nas abordagens do século XIX, posiciona os setores não aristocráticos da sociedade à obscuridade, a meros espectadores da História. São mais sensíveis ao regulamento do que às regularidades. Um outro exemplo disso são abordagens como as de Paul Veyne (1987), na qual propõe que cada classe social teria sua própria subjetivação, embora o orgulho 
continue sendo privilégio das classes aristocráticas (cf. p. 13). Esta manteria seu orgulho e honradez, obedecendo apenas seu semelhante, e à plebe restaria a obediência. De acordo com suas palavras: "Um plebeu se sentiria ultrajado por ver um dos seus semelhantes na miséria e pretender dar-lhes ordens, aceitará de bom grado obedecer a um mestre cuja superioridade, provada através de sinais exteriores, é flagrante" (p. 14).

Trata-se da subjetivação da obediência. Vistos como humildes, absorvem a subjetividade dos notáveis, dos ditos superiores por serem incapazes de absorverem seus valores ${ }^{20}$. Na sua humildade, um plebeu prestaria a obediência a um senhor, como único recurso, "cujos valores se revelem superiores àqueles de que a plebe dispõe; não é humilhante submeter-se a um homem que não pertence ao vulgo. O humilde orgulho do plebeu exige a desigualdade, a dissimetria" (VEYNE, 1987, p. 14).

Manteriam-se nessa subordinação, em especial, por sua condição natural. De acordo com Veyne,

a existência dos primeiros [notáveis] era tão natural como a dos segundos e, digamos, permutáveis; reciprocamente, eles aprovavam o saber estar no seu lugar e se alguém faltasse às suas obrigações seria desprezado ( $p$. 40).

\footnotetext{
${ }^{20}$ Veyne (1993) comenta na obra $A$ sociedade romana, sobre o sentido de inferiorização dos subordinados, fazendo uma análise comparativa sobre a segregação racial nos Estados Unidos com os libertos da sociedade romana. Citemos in extenso: "formou-se entre os negros dos Estados Unidos, separados dos brancos pela segregação racial, um estrato social de milionários de cor que a boa sociedade branca mantém decididamente à distância; eles constituir-se-iam então em numa burguesia negra, que adota os valores e os comportamentos da burguesia branca e encontra nessa imitação uma compensação para o seu sentido de inferioridade; uma sobrecompensação, até, pois que, bem entendido, eles exageram, são milionários excessivos, como Trimalquião é um nobre excessivo e o seu luxo uma caricatura do verdadeiro luxo. A sua existência decorre assim num reino de ilusões, num perene carnaval que não consegue esconder uma angustia secreta" (p. 42).
} 
Esta formulação sobre a condição natural tem por contributo a construção de uma sociedade sem conflitos. Eram, na concepção de Veyne, situações impensáveis, pois a natureza social teria criado

uma série de papéis mais ou menos invejáveis e a sorte individual designou o homem destinado a assumir cada um deles; nada se podia fazer nem contra esta nem contra aquela. Assim, cada qual se aceitava e admitia candidamente a sua condição, para depois se gabar do modo como representara o seu papel (p. 41).

A conseqüência política dessa postura gerou o conceito de despolitização. Bastaria à plebe ter "a satisfação de saber que o rei os ama eternamente, que o seu chefe é genial ou que o povo é soberano. Pouco importa que a bondade de um rei não se traduza em nada, nem sequer em uma redução de impostos" (VEYNE, 1987, p. 18). Segundo a concepção de Veyne (1976), a plebe romana simplesmente não se interessava por política. O circo era a única paixão que seduzia o povo, falava-se pouco de política e muito sobre a continuidade ou não dos espetáculos (cf. p. 86). Citemos in extenso:

a juventude e o bom povo dividiam-se em facções rivais que apoiavam determinado ator, uma equipe de cocheiros, tal categoria de gladiadores, e seu zelo ia desde graves perturbações públicas, sem nenhum fundo político-social e nenhuma distinção de classe (VEYNE, 1989, p. 195).

A multitudo estaria destinada a obedecer e receber benefícios de notáveis e do imperator, não por exigirem seus direitos e sim por corresponder em uma troca: suas riquezas por prestígio ou autoridade ${ }^{21}$. Essa prática faria a sociedade funcionar como uma estrutura, assegurando sua coesão e

${ }^{21}$ Esta interpretação recebeu várias críticas, tais como, considerar como políticas somente as doações obrigatórias, seria uma concepção estritamente institucional. A função pública momentânea de um indivíduo não seria suficiente para definir a natureza das doações; não se podia afirmar que a ambição político-social estava ausente nos atos do oferecimento. Uma grande doação podia auxiliar uma carreira política de modo marcante (JACQUES e SCHEID, 1992); além de que as representações cênicas se prestavam a reivindicações de caráter coletivo (ALMEIDA, 1994; DUPONT, 2003). 
determinando a ruptura de uma ordem natural (cf. VEYNE, 1976). Na obra Como se escreve a História (1983), Veyne deixa claro que na sociedade romana, as doações tinham um lugar de destaque, apesar das motivações diversas: arrivismo, paternalismo, generosidade ou rivalidade. Os pagãos declaravam agir assim por generosidade de espírito cívico em relação à cidade.

A doação seria explicada pelo conceito de evergetismo. Na obra Le pain et le cirque, Veyne (1976) afirma que o evergeta era o gesto de alguém que ajudava a sua coletividade, um mecenato da vida pública. Se as doações não eram destinadas à cidade, não havia evergetismo.

Em outras palavras, o evergetismo seria um ato de uma minoria que realizava ofertas para se afirmar como superior diante do conjunto da sociedade. Os doadores eram notáveis, chefes naturais da população. As doações não seriam uma causa do poder político dos notáveis, nem uma conseqüência direta deste poder, pois o sistema político não exigia o ato ou a doação. A distância social, outra invariante, era o que obrigava a se expressar através das doações (cf. VEYNE, 1976; 1990). Veyne, portanto, classificava a sociedade romana por doações sem interesses, à condição social de pertencer ou não a elite seria um elemento natural, por isso, o uulgus saberia posicionarse em seu devido lugar, restava-lhes obedecer e viver a ilusão do pão e circo. 


\section{Relações interpessoais na sociedade imperial}

Além dessa interpretação vinculada à política do pão e circo, temos importantes pesquisadores como A. Wallace-Hadrill, Peter Garnsey e Richard Saller $^{22}$ que trabalham com a pressuposição de que as relações sociais, no império romano, estavam conformadas pelas interações sociais. Estes optaram por interpretar o poder no Principado, levando-se em consideração o término da política. A submissão do Senado, o fim das assembléias populares e a centralização do poder pelo imperator finalizariam todas as formas públicas do exercício do poder. Mesmo que houvesse discussão, segundo Moses Finley (1997), "o poder deliberativo último e efetivamente ilimitado em matéria de política residia num só homem e não nos votantes (nem nas centenas de membros que o Senado abrangia)" (p. 135).

A partir disso propõem que a construção da sociedade seria pensada a partir de um aglomerado de grupos sociais ordenados, segundo os critérios de concentração material e de prestígio social, hierarquizados como classe ou estamentos que interagiam. Os agentes sociais pertencentes à elite eram capazes, fazendo uso da riqueza e do status, de manter e, ao mesmo tempo, submeter outros agentes sociais e interferir nas decisões do Estado ${ }^{23}$.

\footnotetext{
22 Trata-se de um grupo de pesquisadores, que são denominados Escola de Cambridge termo utilizado por Fábio Faversani - que optam pelo fim da política e privilegiam critérios sociais como a concentração material e prestígio social, para explicar as relações de poder no Império.

${ }^{23}$ Faversani (2000) faz um interessante histórico do caminho trilhado pelos autores Peter Garnsey, Richard Saller e Wallace-Hadrill (cf. pp. 55-68). Faremos um resumo do percurso:

1. A influência recebida de Finley desenha a sociedade romana pela capacidade de diversos grupos adquirirem recursos que possibilita maior liberdade e não mais por conceito de base de classe e estamento.

2. Segundo momento com a publicação, em 1982, do livro Personal patronage under the early Empire, de Richard Saller, que propõe uma maior variabilidade de posições sociais, sendo que a centralização política assume o papel de patronato (FAVERSANI, 2000, p. 56).
} 
Esse controle ocorreria numa arquitetura social: os senhores das principais casas aristocráticas, a partir das relações de patronato, capitaneariam os indivíduos que estivessem mais próximos de sua realidade (cf. WAllace-HadRill, 1996). O patronato envolvia uma relação de troca recíproca de bens e serviços e deveria ser uma relação pessoal assimétrica, quer dizer, patrono e cliente estariam em categorias sociais distintas (cf. SALLER, 1990, p. 49). Wallace-Hadrill (1990) acrescentou que o patronato era um sistema de reprodução de poder. De acordo com suas palavras:

O sistema político romano em todos os tempos demonstrou algum tipo de direito regional na representação no governo. Entretanto, o acesso era mediado através de indivíduos. Foi essa inacessibilidade ao centro, exceto através de círculos pessoais, que gerou o poder do patronato, e foi através do exercício deste poder que o patronato colocou a integração social sem limites e assegurou o controle social (p. 74).

O patronato, fundamentado na troca recíproca de benesses, estabelecia alianças de patronos poderosos para obter recursos, incluindo os indivíduos ligados à lealdade do cliente; e de pessoas mais próximas do poder central com as que estão mais afastados dele, para intermediar recursos através das relações pessoais.

3. Terceiro momento, em 1987, com a publicação do livro The roman empire. Economy, society and culture, de Richard Saller e Peter Garnsey que estabelecem as interações não apenas pela patronagem, mas entre amigos, patronato e proteção.

4. Quarto momento, em 1990, com a publicação de Patronage in ancient society, editado por Wallace-Hadill. Nessa obra, segundo Faversani (2000), "limitavam-se a ver essas interações como fenômenos que não se integravam em redes, em um complexo de interações. É consensual, ainda, que as relações de patronato, por pressupor trocas entre os agentes, existem apenas entre as elites. Os setores subalternos não estariam incluídos entre os que têm algo a oferecer" (p. 57).

5. Quinto momento é a inovação que apresenta Wallace-Hadrill sobre as interações pessoais que ocorrem numa rede de relações interpessoais, configurando a corte imperial. Como discutimos anteriormente, $\mathrm{o}$ autor interpreta a funcionalidade da sociedade a partir da corte. $\mathrm{O}$ imperador está no centro e distribui os benefícios e os indivíduos mais próximos do centro melhor estariam para receber as vantagens sociais e econômicas. Como sintetiza Faversani (2000): "os benefícios produzidos pela sociedade estariam concentrados nas mãos do Imperador, que os distribuiria através de uma rede de dependentes e casa. Quanto mais próximos do Imperador, maiores as chances dos mediadores absorverem benefícios de forma direta ou se apropriar de parte das vantagens que eram encarregados de repassar a outros ou, ainda, extrair benefícios daqueles que deviam o acesso ao Imperador à sua intermediação" ( $p$. $64)$. 
Essas redes de relações interpessoais resultariam em um sistema pouco institucionalizado e, por isso, a sociedade romana se ordenaria e funcionaria pela corte. Esta teria por função prover o acesso do controle físico ao poder político e social. O indivíduo escolhido receberia um caráter de distinção e uma maior proximidade com a casa dourada, o palácio imperial (WALLACE-HADRILL, 1996, p. 300).

A corte imperial tornava-se, portanto, referencial para a constituição do espaço privado das casas aristocráticas. Era a fonte de distribuição de poder e modelo de dominação para outras casas, cuja função era unir em sua volta uma série de outras casas. A domus imperial as subordinava a si e mantinha o controle em cada uma delas, garantindo, assim, a influência do imperator na sociedade. Tal reflexão supõe que as casas aristocráticas reproduziam os costumes da corte imperial e, dessa forma, legitimavam o poder do soberano frente a seus súditos.

Essa reprodução de costumes se efetivava, igualmente, pelas obrigações pessoais do imperator, que eram demarcadas por meio da ritualidade. De acordo com as palavras de Wallace-Hadrill (1996),

A sociedade era constituída pela proximidade ao imperador e apenas os rituais sociais poderiam distinguir os graus de proximidade (..) Em Augusto, rituais, tais como, recepções de embaixadas, conselhos de estado e tribunais, não eram realizados como eventos da corte e sim em virtude das obrigações pessoais do imperador (pp. 285-6) ${ }^{24}$.

Como podemos perceber, os laços sociais envolviam indivíduos de níveis sociais distintos. Havia uma troca entre agentes mais próximos do centro

\footnotetext{
${ }^{24}$ No palácio imperial, segundo Wallace-Hadrill (1996), "a ambivalência arquitetural pública e privada incorpora, em primeiro lugar, a ambigüidade essencial da corte como uma instituição, um domicílio privado com papel central na vida pública, o domus de um cidadão e simultaneamente o pretorium, a sede de um comandante, protegida pela guarda pretoriana" ( $p$. 287).
} 
do poder e entre aqueles mais afastados dele, cujo objetivo era conseguir benefícios com as relações pessoais. O soberano, em virtude de sua posição, controlaria o acesso aos benefícios do sistema (WALLACE-HADRILL, 1990, p. 289).

As análises interacionais da historiografia contemporânea tendem, assim, a limitar a participação dos setores subalternos na estrutura social e na política do Império por dois motivos: o primeiro por propor que os pobres não aparecem, nem mesmo, em inscrições dedicadas às pessoas modestas. Segundo Peter Garnsey e R. Saller (1989),

Muitas das inscrições eram feitas por gente modesta, que não gozava de nenhum prestígio social. Naturalmente, os pobres não são representados nem mesmo em questão de documentos. Por fim, a fonte literária e epigráfica têm em comum a limitação natural devida à sua natureza esporádica. A falta de uma coleção de obras literárias comparáveis ou de um campo representativo de inscrições cuja distribuição no tempo pode ser considerada significativa, torna muito difícil a explicação destas tendências da sociedade romana (p. 131)

O segundo pelo fato de os pobres estarem afastados do centro do poder e por não ter nada a oferecer, uma vez que as trocas entre os agentes ocorreriam sempre no seio da elite ou entre os mais ricos e os menos ricos. Traduzindo em números, Wallace-Hadrill (1990) sugeriu o seguinte quadro:

250.000 pobres urbanos da capital [Roma] eram simplesmente numerosos demais para estabelecer relações pessoais significativas com apenas algumas centenas de membros da elite política. Seus votos são, pela pequena dispersão deles, mais efetivamente controlados através do 'pão e circo"' (p. 69).

Os agentes subalternos conseguiriam alguma distinção, caso estivessem próximos do poder, como o escravo ou o liberto imperial exercendo atividades de funcionário e como mediadores do favor. A emergência e a subordinação pessoal de ajuda se definia pelo acesso ou pela exclusão da 
corte pelo fato de o poder ser "derivado da sua proximidade com o imperador e sua habilidade de influenciar aspectos específicos da distribuição de recursos" (WALLACE-HADRILL, 1996, p. 299) $^{25}$.

Assim reiterava-se, quase num consenso absoluto, que a elite utilizava uma manobra política para divertir a plebe e mantê-la afastada das decisões políticas. Tanto a visão interacionista quanto a historiografia tradicional (aquela do pão e circo) compartilham um ponto em comum: a exclusão da plebe nas esferas de poder. A plebe estaria concentrada apenas em suas reivindicações sociais para

receber dos ricos os meios para continuarem a levar seu tradicional gênero de vida. Os festejos folclóricos e o embelezamento do cenário da vida urbana davam lugar a um sistema de dádivas patrióticas oferecidas pelos notáveis à cidade que governavam (VEYNE, 1993, p. 39).

Esse tipo de interpretação sobre o poder imperial reduz a política a uma "ética do privado, caracterizada por regras de precedência e pelo comportamento adequado aos laços de amizade entre iguais, de patronato ou entre superiores e inferiores" (GUARINELLO \& JOLY, 2001, p. 135). Como sugerem Norberto Guarinello e Fábio Joly (2001), se a ética do privado e as relações pessoais predominassem na política romana como explicaríamos, então,

${ }^{25}$ Esse tipo de interpretação que privilegia a ascensão do liberto pela proximidade com o imperator utiliza fontes documentais como Consolatio ad Polybium, de Sêneca. Este apresenta Políbio, liberto de Cláudio, muito próximo do soberano e tal fato possibilita a Políbio angariar benefícios sociais e econômicos. Segundo Sêneca, "outrora, não só o amor de César te elevou a mais alta esfera social, mas também os teus estudos te projetaram" (Olim te in altiorem ordinem et amor Caesaris extuit et tua studia eduxerunt) (Consolatio Ad Polybium VI, 2). O fato de os libertos imperiais conseguirem, como Políbio, ascensão social, econômica e política não devem ser ignoradas, mesmo porque é um dado evidente nas fontes primárias. O que não se deve compartilhar é a reconstrução de que somente este grupo de libertos teria algum direcionamento social e o restante estaria à margem da sociedade. Essa ficção exclui a maioria que vive de seu pecúlio trabalhando com ofícios ligados ao comércio, ao artesanato entre outros e, igualmente, aqueles mesmos que exigem, segundo Sêneca, termas luxuosas (Epist. Mar. 86, 7). 
que o poder imperial continuasse a se expressar através de uma linguagem (...) política, fundando-se na soberania do Senado e do povo de Roma e em instituições aparentemente públicas, como as magistraturas e o próprio Senado? (p. 135)

Compartilhamos dos mesmos pressupostos, pois

se podemos identificar, na massa heterogênea da plebe, uma certa definição dos meios e dos fins do poder, trata-se, a bem da verdade, de éticas políticas sem formulação sistemática, atuando pelos instrumentos do rumor, da manifestação pública e da agitação aberta (GUARINELLO \& JOLY, 2001, pp.143-4).

Ora, é possível ir além dessa exclusão e até mesmo negá-la, se olharmos as fontes do período imperial sem os pressupostos dessa historiografia. É, assim, que alguns representantes da historiografia brasileira como Funari (2001; 2003), Senna (2005), Joly (2001; 2005), Guarinello (2001), Faversani (1999; 2000; 2002) discordam destes pressupostos e trazem à luz novas interpretações sobre a sociedade romana ${ }^{26}$. Vejamos:

Faversani (2000) faz uma reconstrução dos setores subalternos também pela criação de laços de solidariedade orientados por interesse individual e imediato. A ordenação social se daria pelas solidariedades verticais estabelecidas com os superiores hierárquicos da sociedade. De acordo com sua reflexão é mais razoável aos agentes subalternos

investirem no fortalecimento de um superior hierárquico que se capacitasse para a apropriação crescente de recursos escassos, contando com as vantagens redistribuitivas no interior do seu grupo, do que intentar a construção de ações que levassem a reformas distributivas no interior do seu grupo, do que intentar a construção de ações que levassem a reformas sociais que favorecessem sua condição classista ou estamental (p. 89).

\footnotetext{
${ }^{26}$ Publicada no ano de 2006, Repensando o Império Romano: perspectiva socioeconômica, política e cultural é uma coletânea de autores brasileiros que discute o Império Romano até o século IV. São diversas abordagens distintas, demonstrando, como afirmou Guarinello (2006), uma visão original da História do Império Romano (cf. p. 18). Encontraremos textos sobre a relação da agricultura com a escravidão (JOLY, 2006, p. 65-83), análises das estruturas sociais romanas fundamentadas em documentações epigráficas (CARDOSO \& ARAÚJO, 2006, p. 85107), a compreensão do sistema político do Alto Império Romano (MENDES, 2006, p. 21-51), o estudo da economia do Império pelo azeite produzido na Espanha (FUNARI \& GARRAFFONI, 2006, p. 53-63) entre outras discussões.
} 
Essa situação não eliminaria a contestação à ordem social, pois os agentes dos setores subalternos continuariam exigindo seus benefícios. Haveria, sim, uma diminuição das contestações. De acordo com o autor, "fazem-no de forma individual, por excelência, pressionando por concessões. Isso, por efeito de composição, acaba por gerar uma pressão social que embora dispersa e não-orgânica, é relevante" (p. 44). Um pressuposto formulado por Jon Elster em sua afirmação de que a unidade elementar da vida social é por princípio a ação humana individual (ELSTER Apud FAVERSANI, 2000, p. 46). Para este autor,

explicar instituições sociais e mudança social é mostrar que elas surgem como resultado da ação e interação de indivíduos. Essa visão, com freqüência chamada individualismo metodológico, é, na minha opinião, trivialmente verdadeira (ibidem) ${ }^{27}$.

Essa base teórica fundamentada no individualismo metodológico aproxima autores como Faversani, Wallace-Hadrill e Saller. O ponto de afastamento estaria, segundo o próprio Faversani, na proximidade destes autores com a teoria prática de Pierre Bourdieu. Para este sociólogo, os agentes sociais estariam dispostos dentro de um habitus que é um conjunto de disposições ao qual cada indivíduo adere e incorpora. Cada sociedade possuía uma série de habitus que são frutos das estruturas sociais e é, nesta, que se dá à ação social. Bourdieu (1983) afirma que "as condições para o cálculo racional praticamente nunca são dadas na prática: o tempo é contado, a informação é limitada" (p. 76). Para ele,

\footnotetext{
${ }^{27}$ A teoria do individualismo metodológico inspira vários teóricos, tais como: Pierre Bourdieu (teoria da prática), Erving Goffman (no campo do sociointeracionismo), Raymond Boudon (teoria da metodologia da ação) e Jon Elster (no campo do marxismo analítico). Citemos algumas obras: BOURDIEU, P. Esboço de uma teoria da ação. In: ORTIZ, Renato. Pierre Bourdieu. São Paulo: Ática, 1983; GOFFMAM, E. La presentación de la pesona em la vita quotidiana. Buenos Aires: Amorrortu, 1971; BOUDON, R. Ação. In: BOUDON. R. Sociologia. Rio de Janeiro: Jorge Zahar, 1995 e ELSTER, J. Peças e engrenagens das Ciências Sociais. Rio de Janeiro: Relume-Dumará, 1994.
} 
Os dominantes só aparecem como distintos porque tendo de alguma forma nascido numa posição socialmente distinta, seu habitus, a natureza socialmente constituída, ajusta-se de imediato às exigências imanentes do jogo, e que eles podem assim afirmar sua diferença sem necessidade de querer fazê-lo, ou seja, com a naturalidade que é marca da chamada 'distinção natural': basta-lhes ser o que são para ser o que é preciso ser, i.e., naturalmente distintos daqueles que não podem fazer economia da busca de distinção (1990, pp. 23-4).

De acordo com Faversani (2000), o interacionismo de Bourdieu assume um conjunto de práticas e crenças realizadas de forma irrefletida e sem qualquer pretensão estratégica. Tal opção metodológica é

claramente elitista do ponto de vista político e equivocado empiricamente, ao menos no que se refere à nossa fonte. Sêneca mostra claramente que uma posição social elevada é produto de hercúleo sacrifício e um sem número de temores quanto a sua manutenção (p. 49).

Para ele, o historiador em geral privilegia a opção metodológica de Bourdieu e dos autores Wallace-Hadrill, Saller e Garnsey. Ou seja, as ações dos agentes sociais se davam através de escolhas irrefletidas ou conjunturais. No entanto, para Faversani, tais ações se realizavam por meio de escolhas racionais. As noções como seleção e reforço, entre outras, propiciam a automatização de uma série de ações cotidianas. O que se pressupõe é que há escolha racional, uma motivação apreensível para as ações humanas, mesmo que o cálculo por trás delas não seja refeito a cada tempo ${ }^{28}$.

Contudo, Faversani (2000) concorda com a orientação vertical de formação dos grupos sociais. A aliança geraria a formação de grupos sociais, assim, dar-se-ia privilegiadamente entre indivíduos com posições sociais distintas, em detrimento daquelas que se orientassem horizontalmente, entre

\footnotetext{
${ }^{28}$ Faversani se fundamenta na teoria de Jon Elster para a escolha racional dos agentes sociais. Segundo Elster: "a escolha racional é guiada pelo resultado da ação. As ações são avaliadas e escolhidas não por elas mesmas, mas como meios mais ou menos eficientes para um fim ulterior. Em contraste, o comportamento orientado por normas sociais não está preocupado com resultados" (Apud FAVERSANI, 2000, p. 51).
} 
iguais (p. 67). Sua crítica estaria no desprezo pelo papel desenvolvido pelos setores subalternos nessas lutas sociais, com isto afirma que,

substituir a noção de que as relações sociais de produção ou nos estatutos jurídicos seriam determinantes exclusivos para se compreender a sociedade pela concepção de que as interações pessoais é que ocupariam esse lugar não resolve o problema, apenas resulta em um deslocamento do foco de análise e não em sua ampliação (Ibidem).

Sua proposta seria, então, a ordenação social a partir de três níveis de interação, que se dariam a partir das:

1. Relações Sociais Institucionais (superestrutura) que seriam as "relações sociais reguladas por formulações socialmente reconhecidas, [correspondentes] a um nível das relações sociais em que a igualdade e a desigualdade entre os agentes [eram] preestabelecidas e normalizadas por concessão de direitos e atribuição de deveres institucionais" (p. 70). Em outras palavras, seriam as chamadas relações senhor-escravo e cidadão-não cidadão.

2. Relações sociais de Produção (estruturais) que seriam relações que geram bens ou meios para a sua produção. Um exemplo seria a posição de um "grande proprietário de terras, com capacidade de investimento, tendo muitos trabalhando para si e vivendo da renda aferida com a produção realizada por esses" (pp. 70-1). São situações sociais distintas, embora interrelacionadas.

3. Relações Sociais Interpessoais (sociedade civil) que seriam relações não econômicas e não institucionais que servem como meio de otimização de benefícios. "O lugar de intermediação desse nível é por excelência e em última instância a sociedade civil. São exemplos desse tipo de interação social: as relações de patronato, proteção e amizade" (p. 71). 
Com base nesses três tipos de interações, Faversani constrói a sociedade em Sêneca contendo posições na estrutura econômica e social, i.e., a hierarquização geraria posições determinadas; conteria, igualmente, benefícios institucionais, ordem e posições sociais. A condição social de classe e a condição social estamental não produziriam em si uma posição social do agente. A alternativa seria levar em conta que "a posição social de cada indivíduo só é construída a partir da interação entre os agentes. A posição social é uma situação do agente no meio social. Ela não existe em si” (p. 74). Dessa forma, Sêneca não se preocuparia em apresentar grupos sociais que compunham a sociedade. A divisão social se daria por três binômios: liberdade/escravo, riqueza/pobreza e prestígio/iniquidade (cf. p. 103) ${ }^{29}$.

Como podemos observar, Faversani avança nos estudos sobre as relações sociais na sociedade romana imperial por discordar da pressuposição

\footnotetext{
${ }^{29}$ Além das discussões sobre as inter-relações na sociedade romana, temos autores como Pedro Funari discutindo temáticas que enfocam a cultura popular a partir de grafites de Pompéia. Como sugeriu Funari (1989), "a cultura popular não deixa de ser caracterizada pelas contradições originadas no seio das camadas subalternas. Suas cosmovisões refletem, a um só tempo, a aceitação e a recusa das condições de exploração material e espiritual no interior da sociedade (...) Aquilo que o povo não frui não é aceito ou imitado" (p. 15).

Essas camadas populares da sociedade romana eram forçadas "a trabalhar para viver, escravos e pobres, homens e mulheres sentiam, de forma muito mais clara, a significação de percepção e fruição" (p. 18). Estavam presentes nas tabernas, nos anfiteatros, teatros e templos; assistindo peças de tragédia, recitais e musicais poéticos, comédias, jogos gladiatoriais; participando e exprimindo opiniões tais como: "Marítimo pratica a cunilíngua por quatro asses, mas só aceita virgens: batamos, então, em outro porta" (CIL IV, 7384 Apud FUNARI, 1989, p. 18) ou "Chega de mentiras, taberneiro: você vende água, mas você mesmo bebe vinho!" (CIL IV 3948 Apud FUNARI, 2001, p. 121). Este riso implícito sugere como as "relações humorísticas podem ser encaradas como produtos de reações de poder e de sua contestação, atuando como verdadeira chave para abrir os significados guardados pelos grupos sociais" (FUNARI, 2001, p. 131).

Essa categoria popular foi criticada por Faversani (1994), em uma resenha sobre o livro Cultura Popular na Antigüidade Clássica, pelo fato de o conceito classe ou popular não "agregar todos os agentes subalternos passíveis de serem vistos como pertencentes à classe popular em uma única classe, conceitualmente falando" (p. 33). Funari (1989), diferentemente do que interpreta Faversani, utiliza o conceito de classe como uma ferramenta analítica, mas não cai nos subterfúgios das generalizações. A classe não é abstrata e sim representada por categorias sociais como as de: agricultores, artesãos, comerciários, criadores, domésticos, escravos e feirantes. Entre cada uma das categorias o autor constata subdivisões como artesão de couro, esteira, marfim, criadores de bestas de carga, escravos de aves e assim por diante (p. 29). Esse posicionamento deve-se ao fato de Faversani (2000) caracterizar a sociedade romana pelos laços de solidariedades, desenvolvida de forma detalhada, tempos depois, em sua tese de doutoramento.
} 
de que a plebe seria uma multitudo ociosa, despolitizada e violenta (cf. FriedländeR, 1947; CARCOPINO, 1942; GaGÉ, 1964; RostovtZEFF, 1967; VeYNE, 1976; AlFödY, 1989; RoBeRT, 1995; GRIMAL, 1995); e progride nas análises sobre as relações interpessoais, enfatizando a importância dos setores subalternos, contrariamente aos autores como Saller ou WallaceHadrill, que privilegiam apenas as relações pessoais mais próximas do centro de poder. Quer dizer, os indivíduos próximos do soberano conseguiriam obter vantagens sociais e econômicas, enquanto, setores subalternos estariam afastados por não poderem contribuir, levando-se em consideração a inacessibilidade de recursos ${ }^{30}$.

Embora Faversani tenha obtido um grande êxito nas análises interpessoais da sociedade romana, utilizando como fonte documental obras de Sêneca, deixa de enfatizar dois elementos retratados nelas:

1. De acordo com Faversani, Sêneca não se preocuparia em apresentar os grupos sociais que compunham a sociedade (cf. p. 103); pelo contrário, o estatuto jurídico era relevante na visão senequiana. Se assim não fosse, por qual razão encontraríamos diferenciações entre categorias sociais como plebs, libertos, escravos, senadores e cavaleiros?

2. Além de enfatizar as relações pessoais que comandam a rede de favores e as redistribuições, é necessário compreender, igualmente, os processos de constituição dos "setores subalternos" que se articulavam e se exerciam na esfera pública. Como veremos no capítulo III, as relações entre os

${ }^{30}$ E. C. Guerri (1979) interpreta a estrutura social formada por uma pequena parcela de trabalhadores livres. Segundo a autora, a sociedade é estruturada por três pilares básicos: aristocracia, libertos e escravos (cf. p. 111). Essa construção "tripartida" não conta indivíduos que aparecem em Sêneca como humildes, mendigos, estrangeiros e a afirmação de que libertos privados eram, na realidade, clientes é uma pressuposição vaga. Os clientes aparecem de forma geral no pensamento senequiano, tanto podem ser libertos quanto homens de origem livre. Embora a autora atente sobre esta possibilidade, afirma que a precária situação econômica dos ingenui "os obrigava a recorrer aos patrões para não sucumbir" (p. 112). 
agentes, de modo geral, ocorriam nas esferas pública e privada. A primeira desencadeava movimentos de cunho coletivo, uma identidade de grupo, reagindo contra ou a favor das autoridades. Na esfera privada detectamos, de forma contrária, o privilégio das relações interpessoais entre agentes sociais de posição inferior e superior.

Além desses dois aspectos, a interpretação de Faversani parece ainda uma proposta com um certo conservadorismo e uma estrutura analítica mecanizada. Em primeiro lugar, a perspectiva de dependência dos setores subalternos em fortalecer seu superior hierárquico para que captasse uma maior apropriação de recursos conduz esses setores a uma continua posição de desigualdade. Em segundo lugar, a visão mecanicista de que os indivíduos agiriam por cálculos racionais, propiciando, assim, ações concatenadas na vida cotidiana não pode, de forma alguma, ser generalizante. Assim como a proposta de Bourdieu (1983) em eliminar, por completo, os cálculos racionais na prática social é uma falácia.

Sabemos que os comportamentos de agentes são variáveis, dependem da situação em que se encontram, podendo ou não agir racionalmente (e.g. por escolhas), dos códigos e símbolos socioculturais, das identidades produzidas historicamente e do grau de incerteza entre informação e realidade. Como sugeriu Anton Zeilinger (2005),

Podemos agora colocar a questão: saber o quê? Quem precisa trazer a informação? Isso não leva a um puro solipsismo, isto é, à suposição de que só há no mundo uma única consciência, ou seja, a própria, e que tudo se desenrola no quadro desse saber, no quadro dessa consciência? Freqüentemente se criticou a interpretação de Copenhague porque ela seria uma interpretação puramente subjetivista, porque nela o mundo só existiria na consciência do observador. Para argumentar contra essa posição, só é possível aduzir fundamentos racionais. Assim como muitas outras posições filosóficas, ela não se deixa refutar em termos puramente lógicos. Não se pode duvidar que todos procedemos de maneira 
pragmática, como houvesse outros seres conscientes - outros seres humanos. O homem "é" com outros - ou ele não é absolutamente; ele leva uma vida "partilhada" desde sempre, nesse sentido (p. 266).

Podemos afirmar que só temos acesso à realidade de forma indireta. "Ela é sempre alguma coisa - uma imagem, uma representação, um pensamento - que construímos com base em nossas representações e experiências" (p. 249). Isto não significa que a realidade não seja acessível diretamente, mas podemos supor que tudo o que possuímos são nossas impressões sensoriais, isto é, respostas às questões que colocamos. A realidade vem depois, depende da informação recebida (pp. 252-3). Como afirmou Zeilinger, "o mundo é mais do que pensou Wittgenstein. O mundo é tudo que é o caso e também tudo que pode ser o caso" (p. 270).

Supomos, nesse sentido, que a dinâmica social era muito mais conflitiva do que pretendia a historiografia tradicional, o exercício de poder caracterizava-se não somente por revoltas explícitas, mas em ações que um agente podia realizar com um superior. Devemos, então, atentar ao modo como são criadas e como afetam nossas visões da História. Aos olhos de Guarinello (2003), compreender os limites das reconstruções ou interpretações é uma forma de possibilitar a produção histórica, por meio de visões alternativas que criam e escrevem outros passados. 


\title{
4. Limites e possibilidades: Sêneca como fonte documental
}

\author{
Ninguém passa na estrada. \\ Nem um bêbado. \\ No entanto há seguramente por ela uma \\ procissão de sombras. \\ Sombras de todos os que passaram. \\ Os que ainda vivem e os que já morreram.
}

Manuel Bandeira Noite Morta, 1921

A busca por visões históricas alternativas nos leva a trilhar os caminhos deixados por Sêneca, o que nos ajuda a compreender o poder do povo miúdo na sociedade romana imperial. Encontramos, em nosso filósofo, a aplicação de valores morais em sua experiência individual, como também a pressuposição de critérios que assegurariam a socialização de indivíduos em um universo idealizado e conformado por ações virtuosas. Esta opção de Sêneca em imprimir um valor moral às relações sociais não inviabiliza que se tente reconstruir historicamente, a partir dos textos senequianos, uma certa imagem da sociedade de então ${ }^{31}$.

\footnotetext{
${ }^{31}$ Mirian Griffin (2003), no texto Seneca as a sociologist: De Beneficiis, propõe que o filósofo elaborou uma sociologia de sua sociedade ao retratar a natureza hierárquica, fixando a patronagem como um fenômeno central das relações sociais romanas. Segundo a autora, "o enfoque de Sêneca é como o dos sociólogos quando trata do fenômeno da troca em dois níveis, o da motivação individual ou 'escolha racional' e o da função social - correspondem à microsociologia e à macrosociologia" (p. 103). Faversani (2000), contrariamente, argumenta que "seria anacrônico procurar em Sêneca uma sociologia, convençamo-nos de que é, não só anacrônico, mas também perigoso, limitarmo-nos a apreciações ético-morais do passado" ( $p$. 104).

O fato de as apreciações morais de Sêneca, como sugeriu Faversani, serem perigosas e, que por isso, não deveríamos interpretá-lo como sociólogo não explica o cerne da questão. Se pensarmos que, mesmo nas reconstruções históricas, os objetos são pontuados por historiadores, como também idealizados pela sociedade. Historiadores exercem tais atividades periodizando ou estabelecendo modelos espaciais ou sociais, com isto, estabelecem um padrão em seu estudo. Ou em situações em que a ciência, enquanto tal é utilizada como mecanismo de justificação de políticas que difundi a necessidade de uma pureza racial, a crença na uirtus militar de auto-sacrifício, abnegação e obediência absoluta às ordens; como foi aceito e difundido pelos nazistas alemães e seus aliados, Itália e Japão na Segunda Guerra Mundial. Podemos afirmar que estas circunstâncias afetam o produto final e tanto os textos clássicos quanto os contemporâneos, carregam traços de subjetividade e, portanto, apreciações ético-morais. O que não inviabiliza que realizem construções sobre os comportamentos sociais e individuais do passado e presente.
} 
Entendemos que a compreensão do passado é apreendida indiretamente por haver um obstáculo transponível: os vestígios, informações aleatórias, formadoras de um conjunto de evidências, ou fatos, que carecem em si de ordem, lógica ou conexão. Cabe ao historiador recolher e selecionar dados para transformá-los em fatos a partir de suas próprias teorias, bem como apanhar ou apurar certos modos de se ordenar e pensar o passado, para que se possam propor interpretações ou reconstruções do que aconteceu.

A narrativa histórica comporta elementos como escolha, seleção, recorte e montagem, que são exercícios articulados à capacidade da imaginação criadora de construir os traços de passado, como também de representá-lo. Criamos objetos circunscritos de sentidos cronológico, espacial, cultural e social e dentro deles selecionamos os acontecimentos, tornando-os unidades inteligíveis, adaptando-os a um arcabouço teórico. Este é, claramente, essencial. A partir da teoria, transformamos e interpretamos as fontes primárias em reconstruções específicas da História humana. Como sugerem Sandra Jatahy Pesavento e J. Leenhardt (1998):

é nessa dimensão que a História assume um caráter fictício: ao compor um enredo ou decifrar uma intriga, articulando um discurso que se constrói por fora da experiência do vivido, a História torna presente uma hipótese sobre o passado (p. 12).

O simples fato de representar o real envolve um momento de criação, uma ficção controlada. A História aspira, nesse sentido, uma representância com o real, um possível alcance à verdade. Se não mais aquela verdade inquestionável, a única e duradoura, um regime de verdade que se

Sêneca, em nossa opinião, descrevia uma prática social e não a elaboração de uma teoria social. São proposições diferenciadas. Uma situação é construir um retrato de sua sociedade, a outra é sistematizar, propor uma teoria que explique as relações sociais. 
apóie num desejável e íntimo nível de aproximação com o real (cf. PESAVENTO, 1999, p. 71). Como sugeriu Edgar Morin (2002),

a objetividade aparece como incessantemente autoproduzida e reconstruída por um dinamismo específico das condições organizacionais da comunidade científica. Dito de outra forma, a objetividade é o produto de um processo em anel que só pode ser produzido se a objetividade nele intervier de uma forma produtora. Isto quer dizer que a objetividade não exclui o espírito humano, o sujeito individual, a cultura, a sociedade. Mobiliza-os. Mobiliza os princípios e as potencialidades construtoras do espírito humano e da cultura e exige o seu controle mútuo permanente. Necessita tanto do consenso como do antagonismo e da conflitualidade entre concepções e teorias (p. 17) ${ }^{32}$.

\section{A Literatura assim como a História contribuem com a construção da}

identidade social e individual, conformando modelos de comportamento.

Ambas traduzem possíveis leituras de vida, expressando os jogos das forças sociais e do poder ${ }^{33}$. As duas narrativas têm o efeito de socializar os indivíduos, criando condições simbólicas de coesão social. O que se resgata

\footnotetext{
${ }^{32}$ A subjetividade na História não é uma exclusividade das Ciências Humanas e sim um dado recorrente nas áreas exata e biológica. Um exemplo de incerteza, complexidade e de posicionamentos diversos é o da física quântica; nela, a premissa fundamental é que: "o sistema mais elementar corresponde a um bit de informação" (ZEILINGER, 2005, p. 258). E o que isso implica? Implica que se falarmos em "um sistema elementar que corresponde somente a um bit de informação, nos limitamos sempre a um questionamento específico, no nosso caso, por exemplo, exclusivamente ao exame da informação do caminho" (ibidem). Em outras palavras, a escolha por uma possibilidade, conduz o observador a um resultado especifico, assim como o reflexo de sua realidade (na quântica se classifica por consciência) influência, igualmente, o resultado final. De acordo com Zeilinger, "toda vida exige sobrevida. Toda vida exige decisões constantes. Todas as decisões só podem ser tomadas com base na informação que se possui. Em última instância, por sua vez, essa informação não é nada mais do que 'respostas de sim e não' as perguntas" (p. 264).

${ }^{33}$ Devemos ressaltar, quanto ao ofício do historiador, que a disciplina oferece operações especificas: "construção e tratamento dos dados, produção e hipóteses, crítica e verificação de resultados, validação da adequação entre o discurso do conhecimento e seu objeto. Mesmo que escreva de forma literária, o historiador não faz literatura, e isto pelo fato de sua dupla dependência. Dependência em relação ao arquivo, portanto em relação ao passado do qual ele é vestígio" (CHARTIER, Apud DELGADO, 2000, p. 182). White confere um outro sentido a História: para ele, "dizer que conferimos sentido ao mundo impondo-lhe a coerência formal que costumamos associar aos produtos dos escritores de ficção não diminui de maneira nenhuma o status de conhecimento que atribuímos à historiografia. Só diminuiria se acreditássemos que a literatura não nos ensinou algo acerca da realidade, por ter sido o produto de uma imaginação que não era deste mundo, mas de outro, de um mundo inumano" (Apud DELGADO, 2000, p. 185).
} 
da Literatura, como fonte documental, é a representação do mundo que comporta a forma narrativa ${ }^{34}$.

É, portanto, nessa tentativa de reconstruir algumas imagens do passado, que queremos ressaltar a relevância, pelo menos do ponto de vista documental, dos textos de Sêneca para compreender os setores subalternos da sociedade romana. Muito embora historiadores clássicos enfatizem a preponderância de questões morais no discurso de Sêneca e sua posição aristocrática como senador e amigo do princeps, a inviabilidade de utilizá-lo como fonte documental pela deformação das crenças destes setores, analisando-os por filtros e intermediários. Como sugeriu Carlo Ginzburg (2006), não devemos exagerar, pelo fato

de uma fonte não ser "objetiva" (mas nem mesmo um inventário é "objetivo") não significa que seja inutilizável. Uma crônica hostil pode fornecer testemunhos preciosos sobre os comportamentos de uma comunidade camponesa em revolta (p. 16).

A sátira Apocolocyntoses, os tratados filosóficos e as cartas não são apenas um emaranhado de idéias estóicas, epicuristas e platônicas que o filósofo elaborou para redesenhar, de acordo com sua concepção, uma sociedade mais ordenada. Sêneca retratou categorias e condições sociais que refletiam fatos contemporâneos à sua época. O filósofo descreveu o cotidiano dos setores subalternos - sob temáticas como a política, o poder, o comércio,

${ }^{34}$ Para um maior aprofundamento das questões teóricas acerca da objetividade histórica consultar: PESAVENTO, S. J. Fronteiras da ficção: diálogos da História com a Literatura, Estudos Históricos, Franca, v. 06, n 01, 1999; LOPES, Fábio Henrique. A história em Xeque: Michel Foucault e Hayden White. In: RAGO, Margareth \& GIMENES, Renato Aloizio de Oliveira (orgs.) Narrar o passado, repensar a História. Campinas: Unicamp, 2000; REIS, R. (Re)lendo a história. In: PESAVENTO, S. J.; LEENHARDT, J. (org.) Discurso histórico e narrativa literária. Campinas: Unicamp, 1998; WHITE, H. Trópicos do discurso: ensaios sobre a crítica da cultura. São Paulo: Edusp, 2001; FONTANA, Josep. História depois do fim da História. Bauru: Edusc, 1998; HUNT, L. (org.). A nova História Cultural. São Paulo: Martins Fontes, 1995. FUNARI, P. P. A. Os debates historiográficos sobre Antigüidade Clássica e as Ciências Humanas: Letras, Literatura e Lingüística. Argos, Argentina, no 21, ano XXI, 1997 e CHARTIER, Roger. Pour comprendre l'histoire. Le Monde, Paris, Jeudi 18 mars, 1993. 
a pobreza, os jogos gladiatoriais, a morte entre outros - vinculados às situações concretas e particulares ou por formulações abstratas. Podemos observar, por meio da crítica senequiana, o cotidiano (crenças, hábitos) de quem se critica.

A depreciação dos setores subalternos por Sêneca mostra o grau de popularidade e participação destes no espaço social, até pouco, interpretado pela historiografia contemporânea, como sendo concedidos à elite romana. Temos, sem sombra de dúvida, um padrão moral implícito no discurso senequiano, assim como práticas e comportamentos de indivíduos que não pertenciam ao seu universo social ${ }^{35}$.

Queremos ressaltar, portanto, que o testemunho senequiano tem um importante valor histórico sobre a primeira metade do Império Romano. A posição social e condição política de Sêneca, a filosofia moral e sua experiência em outras regiões do Império, fizeram com que o filósofo tivesse uma percepção mais abrangente de sua realidade contemporânea. Sêneca não se restringiu apenas ao soberano ou aos seus concidadãos da aristocracia; em suas obras encontram-se imagens que retratam comportamentos de barbeiros, prostitutas, gladiadores, libertos e escravos. Isso propicia unidade às suas obras, pois o filósofo descrevia a sociedade romana como um todo, assim como suas particularidades, enfatizando a honra, a riqueza, os favores, a popularidade, o estatuto jurídico, o patrimônio como elementos geradores de prestígio social.

\footnotetext{
${ }^{35}$ Não compartilhamos com Marta Giacchero (1980), quanto ao seguinte aspecto: "Se nos diálogos, além da incerteza de uma cronologia não definida, parece predominar dolorosas vicissitudes pessoais ou motivos consolatórios, ou ainda uma finalidade parenética obtida da tradição filosófica clássica, as obras compostas após o retiro da vida pública refletem a complexa maturidade de experiências e de problemas vividos no decênio de Nero" (p. 1089). Nas obras de Sêneca, independentemente de suas pretensões particulares, apresentam reflexões sobre a riqueza, pobreza, intrigas políticas, corrupção, status sociais e jurídicos como escravos, libertos, plebe, senadores entre outros.
} 
Concluímos lembrando as palavras do escritor Machado de Assis

(1978) sobre a construção histórica:

Suetônio deu-nos um Cláudio, que era simplório - ou uma abóbora, como Ihe chamou Sêneca, e um Tito, que mereceu ser as delícias de Roma. Veio modernamente um professor e achou meio de demonstrar que dois Césares, o delicioso, o verdadeiro delicioso, foi a abóbora de Sêneca (...) Viva, pois a história, a volúvel história que dá para tudo; e, tornando a idéia fixa, direi que é ela a que faz os varões fortes e os doidos; a idéia móbil, vaga ou furta-cor é a que faz os Cláudios (p. 18) ${ }^{36}$.

${ }^{36}$ Essa obra de Machado de Assis - Memórias Póstumas de Brás Cubas - foi em 1881. Utilizamos a seguinte publicação: ASSIS, Machado de. Memórias póstumas de Brás Cubas. São Paulo: Abril Cultural, 1978. 


\title{
CAPÍTULO $\|$
}

\section{A trajetória social e política de Sêneca}

\author{
O Olho é uma espécie de globo, \\ é um pequeno planeta \\ com pinturas do lado de fora. \\ Muitas pinturas: \\ azuis, verdes, amarelas. \\ É um globobrilhante: \\ parece cristal, \\ é como um aquário com plantas \\ finamente desenhadas: algas, sargaços, \\ miniaturas marinhas, areias, rochas, naufrágios e peixes de ouro.
}
Mas por dentro há outras pinturas, que não se vêem: umas são imagens do mundo, outras são inventadas.

O Olho é um teatro por dentro.

$E$ às vezes, sejam atores, sejam cenas, e às vezes, sejam imagens, sejam ausências, formam, no Olho, lágrimas. 


\section{Contextualização histórica: o poder imperial}

Sêneca nasceu entre os anos 4 e 1 a.C. e sua morte é datada em 65 d.C., período que, em termos políticos, se caracteriza pelo processo de concentração de poder nas mãos do príncipe. Havia um esforço administrativo direcionado a uma maior centralização, quer dizer, o soberano passava a acumular todos os poderes, embora existissem os órgãos da República. Segundo a historiadora Norma Musco Mendes (2006), o Principado estaria associado às mudanças nas relações políticas que se traduziriam em necessidades de gerir novas

condições sociais, econômicas, militares e administrativas surgidas pela criação do Império, exigiram o desenvolvimento de um regime político de caráter pessoal, porém sob uma máscara republicana. Foi estruturada do modelo romano de poder pessoal, podendo ser chamada de "monarquia republicana" (p. 27).

O reflexo dessa centralização é observado na concessão de poderes. No caso de Augusto, o Senado deu poderes especiais, dentre os quais o comando das províncias da Espanha (menos a Bética) Gália, Síria e Egito. Estas foram mantidas como suas propriedades e eram comandadas por aristocratas da ordem eqüestre. O Egito, por exemplo, tornava-se importante pelo fato de o trigo - para o abastecimento de Roma - vir, normalmente desta região. Tais concessões permitiram a Augusto o comando de quase todas as forças armadas do Império Romano.

Dentro deste quadro, permanecia, entretanto, o mecanismo vigente de eleição. Elegiam-se magistrados todos os anos e os procônsules saíam para governar as províncias que não se incluíssem àquelas de Augusto. Os senadores esperavam, uma vez terminado o seu mandato de cônsul, que fosse 
dirigir suas províncias, mas continuava a candidatar-se ao consulado, sendo reeleito ano após ano - Augusto fora cônsul desde o ano 31 a. C..

A aristocracia senatorial via com insatisfação a repetição unipessoal do consulado pela tradição republicana não admitir eleição seguida, a menos que ocorresse com interrupções longas. Situação esta que diminuía a rotatividade entre os senadores pretendentes ao cargo de cônsul. Em resposta, Augusto, em meados de 23 a.C., renunciou ao consulado na tentativa de mostrar com clareza seu "sentimento republicano". Ainda que tal recusa não diminuísse sua potestas. Recebeu, além disso, o maius imperium e os direitos de eleger o tribuno da plebe (Res Gestae, 5 e 12). Em 19 a.C., os senadores não concederam formalmente os poderes consulares, permitiram, entretanto, a manutenção de suas tropas nas regiões de Roma e da Itália, como se fosse cônsul.

Em 12 a.C., Augusto recebeu o cargo religioso de Pontifex Maximus o que o tornava chefe supremo do culto nacional, presidindo, dessa forma, os comícios calatos e tributos. Era ainda encarregado de eleger os sacerdotes e vestais e o responsável pela nomeação dos flâmines, bem como o rex sacrorum, tendo autoridade sobre eles. Tornava-se, sobretudo, o mediador entre homens e deuses ${ }^{37}$.

${ }^{37}$ Temos um excelente estudo realizado por Ernst H. Kantorowicz (1998) - Os dois corpos do rei: um estudo sobre teologia política medieval - sobre a sacralização e as vicissitudes do carisma de monarcas no mundo ocidental em um período de duzentos anos. O rei era visto em "um estado de 'perfeição absoluta' sobre-humana dessa persona ficta real" (p. 18). Havia, sobretudo, uma diferenciação entre o corpo natural e o corpo político. Este "é um corpo que não pode ser visto ou tocado, composto de Política e Governo, e constituído para a condução do povo e a administração do bem estar público, e esse corpo é extremamente vazio de Infância e velhice e de outros defeitos e imbecilidades naturais, a que o corpo natural está sujeito, e, devido a esta causa, o que o rei faz em seu corpo político não pode ser invalidado ou frustrado por qualquer incapacidade em seu corpo natural" (p. 21).

Esse conteúdo sagrado de poder gerava o reconhecimento de que governantes e deuses possuíam propriedades semelhantes e, como tal, refletia a distância entre rei e súditos. Levava-se em consideração, a associação de poderes superiores à pessoa real e sua própria legitimidade (cf. BALANDIER, 1969; GEERTZ, 1997). Era uma forma de sacralizar o poder, pois 
Além desse poder sagrado, Augusto criava novos cargos, a saber, o concilium principis, utilizado pelo imperador para reunir funcionários confiáveis, especialmente, os jurisconsultos; prefeito do pretório, comandado por um oficial-cavaleiro, compunha a guarda de corpo do imperator, garantindo, desta forma, a segurança e uma maior estabilidade de Augusto no poder; prefeito da anona era chefiado pelos eqüestres que se responsabilizavam pelo abastecimento de trigo em Roma; prefeito da guarda, também cavaleiro, garantia o policiamento noturno e o serviço de incêndios; e para finalizar, o prefeito da cidade que era comandado por um senador que chefiava as cortes urbanas com jurisdição em Roma.

Essas secretarias, segundo Mendes, absorveram as atribuições do consulado e edilato, criaram uma aristocracia de serviço, formada por senadores e eqüestres que se vigiavam e contrabalançavam mutuamente em relação à influência uma da outra (MENDES, 2006, p. 32). O imperator passava a monitorar questões administrativas e políticas, debatidas e discutidas por alguns homens no concilium principis. De acordo com Mendes:

as principais questões de governo, sem dúvida, eram debatidas numa outra instância, formada pelos amigos de Augusto, designada Conselho do Príncipe. Com o fortalecimento do governo imperial, a importância deste conselho foi aumentando, passando a ser o responsável pelo destino de Roma e do mundo (p. 30).

O Senado perdia a importância como instituição política, os senadores recebiam o título individual e estavam dependentes dos cargos e da proximidade com o imperator no Principado. Esta política fundada em relações de pessoalidade e em regras informais pôs fim, segundo Mendes, às

toda sociedade almejava a eternidade e temia, igualmente, o retorno ao caos como realização da própria morte (cf. BALANDIER, 1969, p. 95). Mesmo Balandier ou Geertz terem estudados outros períodos históricos, podemos supor igualmente acerca da sacralização do poder na sociedade romana. 
atribuições eleitorais, reduzidas à recomendação de candidatos aos comícios e o fim da participação popular (suprimidas em 14 d.C. por Tibério), tornando as eleições uma mera formalidade (cf. p. 30).

Pode-se afirmar que a centralização do poder político foi um dado evidente a partir de Augusto e reproduzido em propagandas ${ }^{38}$ como o culto oficial do imperador e a iconografia. Vejamos:

1. O culto oficial baseava-se na lealdade em que os imperadores tentavam garantir: "por intermédio de todos os meios possíveis de serem usados na época, como a construção de lembretes de sua importância para a manutenção do Império, como as estátuas, as inscrições e os edifícios públicos

\footnotetext{
${ }^{38}$ Utilizamos o conceito de propaganda proposto por Ana Teresa M. Gonçalves (2002) que é definido por "um conjunto de símbolos, idéias e imagens que eram divulgadas no território imperial, mediante a utilização de vários suportes, formando em seu conjunto a imagética imperial" (p. 13). Embora ela analise as propagandas do Principado de Severo e Caracala, podemos supor, mesmo em se tratando de recortes espaciais distintos, que o primeiro século foi conformado por imagens que objetivavam a consolidação da centralização política no Império Romano.

Um exemplo de iconografia imperial encontra-se na numismática, quer dizer, "as moedas de menor prata e bronze eram (...) distribuídos à plebe de Roma. As moedas de menor valor tinham uma execução mais rudimentar e, por circularem mais, se desgastavam mais rapidamente, passando uma informação mais reduzida" (ZEHNACKER, 1987, p. 321-325 Apud GONÇALVES, 2002, p. 94). Mendes utiliza também a iconografia imperial para explicar, de certo modo a centralização. As estátuas de Augusto teriam por função: seduzir, persuadir e intimidar o subordinado, exercendo comunicação política as seguintes funções:

1. "Afirmar e ratificar a hierarquia de poder, a potencialidade da coerção e a estrutura normativa da sociedade; 2. Dissimular: ao controlar e custear a organização do transcrito público a classe dominante cria uma aparência ideal do poder para ser vista pelos subordinados, protegendo o seu status quo e escondendo aquilo que deve ser camuflado da sua grandeza e autoridade; 3. Eufemizar: a utilização de eufemismo num transcrito público objetivo obscurecer algo que é negativamente valorizado e pode se tornar embaraçoso, transformando e exaltando o seu aspecto inofensivo, benéfico e positivo. Particularmente é usado para obscurecer o uso da coerção. Como exemplo, poderíamos citar: o uso político do termo pacificação para ataque armado e ocupação; punição capital, exílio, confiscações empreendidas pelo soberano como uma medida exemplar para bem do Estado; 4. Estigmatizar atividades ou pessoas que se opõem aos parâmetros oficiais. Rebeldes ou revolucionários são chamados de inimigos do Estado, rebeldes ou criminosos; 5. Unanimidade. As demonstrações públicas que celebram e retratam o poder produzem a aparência de unanimidade entre a classe dominante e o consentimento do subordinado, na medida em que são reuniões coletivas autorizadas, promovidas e custeadas por aqueles que detém o poder. A exibição de unanimidade é o componente visual da ideologia hegemônica, fornecendo plausibilidade a eufemização do poder e buscando promover a integração social” (p. 40).
} 
erigidos em sua homenagem e lembrança" (JACZYNOWSKA, 1989 Apud GONÇALVES, 2002, p. 20) ${ }^{39}$.

2. A iconografia imperial era um dos ícones de manutenção do Imperium. Como sugeriu Ana Teresa M. Gonçalves, os retratos, os símbolos e as alegorias deveriam ser representações claras e controladas. Inseridos em ambientes como fóruns, santuários e termas, locais freqüentados pela população, "com fins propagandísticos e de exaltação da família (gens) da pessoa representada" (p. 76).

3. Um outro sintoma de consolidação da centralização está na questão, por exemplo, de como Sêneca direcionou seu pensamento político estóico à posição do imperador (OMENA, 2002). Para o filósofo, o monarca se diferia do tirano, não pela legitimidade do poder ou por suas limitações, mas na forma como o soberano ou tirano usavam o poder (De Clementia I, II. 4). Este deveria ser mediado pela clementia que estabelecia as relações entre governante e subordinado, devendo ser esta de caráter humanitário (cf. BRAREN, 1985).

Realeza e tirania possuíam, no entanto, os mesmos desígnios. A diferença encontrava-se na clemência, pois um bom soberano não exagerava

\footnotetext{
${ }^{39}$ Norma Musco Mendes e Uiara Barros Otero, em relação ao culto oficial, enfatizam a existência de um "forte fator de identidade cívica local e romana, da mesma forma que os tradicionais cultos públicos, sendo realizado em ocasiões especiais, como, por exemplo, o aniversário do imperador, para celebrar uma importante vitória. No nível provincial, todas as cidades enviavam representantes para um santuário comum onde eram feitos os rituais ao imperador e se escolhia o sacerdote dentre os provinciais, o qual naturalmente tinha uma posição de prestígio e era certamente um dos mais ilustres da região. Os notáveis das cidades, por sua própria iniciativa, podiam construir templos e realizar o culto aos imperadores" (MENDES \& OTERO, 2005, p. 206). Ainda segundo as autoras, "o culto ao imperador era um fator de integração social. Ademais, era um momento para a exibição e afirmação da hierarquia social local, pois o colégio dos augustales, sacerdotes encarregados dos empreendimentos do culto, socializou os libertos e integrava os pobres. Além disto, o cerimonial do culto incluía a distribuição de presentes, alimentos e vinho, algo que pode ser interpretado como uma tentativa de se buscar a unanimidade de participação das diferentes classes sociais municipais" (p. 207).
} 
nos rigores da lei e nem sentia prazer em castigar. O tirano, pelo contrário, era cruel $^{40}$ por prazer (De Clem. III, IX, 4).

Podemos supor que o fato de Sêneca ter elaborado o tratado De Clementia, nos anos finais de 55 e início de 56, refletia dois elementos:

1. Primeiro, a existência de um sistema centralizado de poder político fundamentado nas decisões do imperador, vigente em sua época.

2. Segundo, Sêneca utilizou o tratado para a legitimação de Nero no poder. A clementia projetada como "idéia-força" servia para proporcionar um novo vigor ao poder imperial. A República, ao que tudo indicava, parecia-lhe a melhor escolha; no entanto, a condição para a sua realização não era mais possível, em especial, pela falta de compromisso com a República e pela troca de favores entre os senadores (FAVERSANI, 2000; OMENA, 2002). Essa mudança foi datada, de acordo com Sêneca, com a morte de Catão, o único defensor da República (Epist. Mor. 104, 30, 31).

Cabia, portanto, a Nero, considerado um soberano clemente e representante dos deuses (De Clem. Pr. I, 2), manter o poder concentrado em suas mãos. De acordo com Sêneca, o imperator era o vínculo, cujo poder garantiria a coesão das forças públicas.

Ele é o sopro vital que arregimenta estes tantos milhares que por si mesmos nada seriam a não ser ônus e presa de guerra, se esta idéia de império lhes fosse tirada. Preservado o rei, todos têm um único ideal. Perdido o rei, todos rompem o compromisso de fidelidade(ille spiritus uitalis, quem haec tot milia trahunt nihil ipsa per se futura nisi onus et

\footnotetext{
${ }^{40}$ Sêneca, em uma passagem, atribui Fálaris o título de cruel, dizendo: "Darei o nome de cruel àqueles que têm motivo de punir, mas não têm nenhuma medida, como Fálaris, de quem afirmam que seviciou homens, por certo não inocentes, porém numa dimensão que ultrapassa a medida do humano e do admissível" (Illos ergo crudelis uocabo, qui puniendi causam habent, modum non habent, sicut in Phalari, quem aiunt non quidem in homines innocentes, sed super humanum ac probabilem modum saeuisse) (De Clem. II, II, 3). (De Clem. II, II, 3). Segundo Ingeborg Braren (1990), Fálaris tornou-se lendário por torrar inimigos dentro das entranhas de um touro de bronze (p. 45).
} 
praeda, si mens illa imperii subtrahatur. Rege incolumi mens omnibus uma, amisso rupere fidem) (De Clem. III, II, 1$)^{41}$.

Esse chefe clemente estaria unido aos preceitos da sabedoria, com isso, teria condições de evitar a violência, protegendo os mais fracos dos mais fortes e discerniria o que tivesse ou não utilidade. Neste caso, a clemência deveria ser apreendida pelo esforço pessoal, assim, o soberano, guiado pela virtude, proporcionaria harmonia à sociedade. Era quem fazia o populus existir, por isso, o mau imperador, conduzido pela falta de razão, tratando os cidadãos com injustiça ou punindo com requintes de crueldade, causaria um caos absoluto em todo o ordo social.

Isso não implica que a centralização política tenha liquidado a negociação do soberano com setores sociais. Primeiro, a boa convivência do imperador com seus súditos dependia de suas ações moderadoras, segundo, as reações poderiam advir tanto de ações coletivas quanto de ações individualizadas. O poder Imperial, embora estivesse centrado in manu principis:

não era absoluto, mas, em grande medida, delegado e compartilhado. 0 próprio Senado era um parceiro importante, que por mais centralizado que fosse detinha o poder, mesmo que subordinado, tanto como instituição, com suas atribuições específicas, quanto como poder individual de seus membros que monopolizavam as principais magistraturas civis e militares do Império (GUARINELLO \& JOLY, 2001, p. 137).

Um exemplo disso aparece na sátira Apocolocyntoses em que o senado celestial ao discutir a deificação de Cláudio acionava um verdadeiro mercado de votos. Cláudio receoso em não obter a glorificação convence

\footnotetext{
${ }^{41}$ Obras que analisam de forma detalhada a estrutura do De Clementia: Consultar: PRÉCHAC, François. Le traité De Clementia. In: SÊNECA, L. A. De la Clémence. Paris: Les Belles Lettres, 1990; GRIMAL, Pierre. Sénèque ou la conscience de l'Impire. Paris: Les Belles Lettres, 1991; GRIFFIN, Miriam T. Seneca: a philosopher in politics. New York: Oxford, 1976.
} 
Hércules, por meio de enaltecimentos, a favorecê-lo (Apoc. VII, 4). Jano, contrariamente, tomou a palavra e posicionou-se contra Cláudio, propondo que fosse chicoteado por gladiadores noviços (Apoc. IX, 3). Hércules, entretanto, articulava contra o deus Jano, convencendo Diéspiter, com jeitinho, a propor que Cláudio se tornasse deus (Apoc. IX, 4). As opiniões dividiam-se e

Hércules batendo o ferro enquanto estava quente, corria continuamente, sussurrando a cada um: 'não me negues este favor, é para mim uma questão pessoal. Amanhã se precisares de mim, retribuir-te-ei: uma mão lava a outra"' (Hercules enim, qui uideret ferrum suum in igne esse, modo huc, modo illuc cursabat et aiebat: "Noli mihi inuidere, mea res agitur; deinde tu si quid uolueris, in uicem faciam: manus manum lauat") (Apoc. IX, 6).

Sêneca demonstra, de forma evidente, a institucionalidade do Senado, ainda que o sistema de poder político tenha se tornado, no início do império, mais centralizador, continuava a existir como instituição e pelo poder individual de seus membros de articular e negociar.

Um outro exemplo em Sêneca surge no momento em que aconselha Nero manter boas relações com os setores da elite e com os subalternos. De acordo com Sêneca, mesmo os homens humildes, a quem tudo faltava, deveriam ser chamados com o nome de homem (De Clem. Pr. I, 3). O princeps que mantinha uma relação pautada na moderação, na clemência, recebia em troca admiração, aprovação das ordens e fidelidade de todo o populus, sem distinção de grupos sociais.

Nero tratou de montar um aparato administrativo estatal, consolidando a estrutura burocrática, diminuiu o poder dos libertos, mesmo tendo funcionários com ampla autonomia, atendeu os interesses aristocráticos, excluindo os libertos de cargos de pretura e questura, acrescentou a isenção das taxas patrimoniais dos navios mercantes, para facilitar o transporte de 
grãos e a desvalorização monetária e desenvolveu o comércio como forma de melhorar, sobretudo, as condições da plebe (FINI, 1993).

Foi amado e respeitado pela plebe, no entanto, a sua péssima reputação deve-se, muito provavelmente, a alguns autores cristãos como Vitorino, Comodiano, Sulpício Severo, que sustentaram que ele seria o anticristo que retornaria cedo ou tarde a terra e pela oposição estóica de alguns aristocratas (GUARINELLO, 1996); em 68 termina seu principado com o seu possível suicídio ${ }^{42}$.

Temos, portanto, um sistema centralizado que não conseguiu eliminar a rede complexa de intrigas, oposições que ocorriam em um âmbito individual ou em grupos sociais: "uns mais, outros menos organizados, com distintos graus de influência política e diferentes instrumentos de manifestação" (GUARINELLO \& JOLY, 2001, p. 137) - que influíam na queda e imposição de outro imperador.

Neste ambiente nasceu o filósofo do stoa na província da Bética, na cidade de Córdoba $^{43}$. Mudou-se para Roma com sua família e, tempos mais tarde, sua saúde precária levou-o a deslocar-se até o Egito por volta de 25, onde se hospedou na casa de sua tia materna. Quando retornou, em 31, ocupava o cargo de questor ${ }^{44}$.

${ }^{42}$ Obras de Consulta: SCULLARD, H. H.. From the Gracchi to Nero: a history of Rome (133 B.C. to A.D. 68). London: Routledge, 2001; CIZEK, E. Néron. Paris: Fayard, 1982; YAVETZ, Z. Plebs and Princeps. Oxford: Oxford University Press, 1969; GUARINELLO, N. Nero, o estoicismo e a historiografia romana. Boletim do CPA, Campinas, ${ }^{\circ}$ 01, jan./jun., 1996; FINI, Massimo. Nero: o imperador maldito. Dois mil anos de mentiras. Trad. Mércia Justum. São Paulo: Scritta, 1993 e RUDICH, Vasily. Political dissidence under Nero: the price of dissimulation. London: Routledge, 1993.

${ }^{43}$ Consultar Anexo I: figura com a localização de Córdoba, cidade de nascimento de Sêneca.

${ }^{44}$ Sobre a vida de Sêneca, consultar: GRIMAL, P. Sénèque ou la conscience de l'empire. Paris: Fayard, 1991 e GRIFFIN, Miriam T. Seneca: a philosopher in politics. New York: Oxford, 1976. 
Sabe-se que o acesso a cargos importantes no mundo romano ocorria, sobretudo pela proteção de uma pessoa rica e poderosa. Sêneca foi aceito na ordo eqüestre por ter nascido em uma família rica, um dos motivos pelos quais foi admitido na aristocracia e pôde, com isso, viver e sustentar sua riqueza em Roma. Na obra Consolatio ad Helviam, Sêneca relatou a influência da tia e de sua união matrimonial com o prefeito C. Galério, o que lhe rendeu a conquista do cargo de questor, mais ou menos em 34 ou 35 d.C. (Consolatio ad Helviam XIX, 1).

Sêneca, em 39, pronunciou um discurso na presença de Calígula, provocando a vaidade e a inveja do imperator. Esta alocução resultou no menosprezo e na cogitação em condená-lo à morte. A evidência do conflito com Calígula aparece em obras como De Ira, Apocolocyntoses e De Beneficiis. Ainda que o filósofo tivesse se livrado de Caio César, dois anos mais tarde, foi condenado ao exílio na ilha de Córsega, por ser acusado de envolvimento amoroso com Júlia Livila, sobrinha do princeps. A razão mais provável da condenação de Sêneca foi sua inimizade com Cláudio e a possibilidade de aliar-se à oposição senatorial estóica, que tendia à monarquia ${ }^{45}$.

O episódio do exílio apareceu na narrativa taciteana quando Agripina quis torná-lo preceptor do jovem Nero (Anais XII, VIII). A experiência do exílio aparece nas obras de Sêneca em dois momentos: no momento em que redigiu a carta consolatória para a sua mãe - Consolatio ad Helviam - que se encontrava inconformada pela falta de sorte do filho; o segundo momento, o

45 Surgiam, freqüentemente, delatores que denunciavam seus inimigos para angariar vantagens em proveito próprio. Tanto os textos de Sêneca quanto os de Tácito mostram um emaranhado de intrigas pessoais pela disputa de vantagens e benefícios oferecidos pelo soberano. O acusado, normalmente, incorria no crime de lesa majestade por intentar contra a vida do princeps. Os senadores reuniam-se em um tribunal supremo para julgar o réu, mas a decisão final, no entanto, pertencia ao princeps. 
filósofo escreveu uma missiva a Políbio para amenizar o sofrimento causado pela morte de seu irmão. Sêneca aproveitou para fazer uma solicitação indireta ao imperador para retornar a Roma (Consolatio ad Polybium XIII, 3), mas não obteve apoio.

A sorte de Sêneca modificou-se a partir do momento em que Narciso, liberto de Cláudio, preparou o assassinato de Messalina, esposa do imperator. Cláudio casou-se com sua sobrinha Agripina e foi permitido ao filósofo, em 49, retornar a Roma para tornar-se preceptor de Domício. Para Tácito, Agripina ganhou um aliado político com a presença do filósofo na corte, por dois motivos: por ser natural que conservasse rancor em relação a Cláudio, pela lembrança do exílio e, ao mesmo tempo, estaria agradecido pela mão benfeitora de Agripina (Tácito, Anais XII, VIII) ${ }^{46}$.

Cláudio, anos mais tarde, em 54, foi envenenado por Agripina. Nero, nomeado sucessor de Cláudio, escolheu Sêneca e Burro para se tornarem amici do imperator ${ }^{47}$. Após alguns anos ao lado de Nero, Sêneca começou a perder seu prestígio frente ao princeps. Um primeiro sinal de crise apareceu com a morte de Afrânio Burro, o único homem que, talvez, pudesse apoiá-lo na casa imperial. Diante de tais circunstâncias, Sêneca decidiu retirar-se da vida

\footnotetext{
${ }^{46}$ Nero casou-se com Otávia, filha de Cláudio e Messalina. Após a união, Agripina convenceu Cláudio, em 51, a adotar Domício. Este passou a ser chamado de Nero e com isso, tornou-se herdeiro ao trono, assim como, Britânico, filho legítimo de Cláudio e Messalina. Cabia ao imperador escolher o próximo candidato ao trono.

47 Segundo David Konstan (2005), a palavra amicitia tem uma variada gama de significados, embora os filósofos se refiram, quase sempre, à relação específica entre amigos (p. 173). Este tipo de relação engloba a reciprocidade de benefícios que "é, em princípio, distinta da relação entre amigos, que idealmente agem por motivos de generosidade e requerem que cada gentileza seja plenamente retribuída" (p. 181). Para o autor, Sêneca referia-se em um único momento ao tema da amizade "para responder ao paradoxo de que os amigos não podem conceder beneficia porque possuem todas as coisas em comum" (Apud KONSTAN, 2005, p. 181). Consultar: PETERLINI, Ariovaldo Augusto. Uma visão senequiana da amizade. Letras Clássicas, n 03, São Paulo, 1999, pp. 95/108.
} 
pública em 62. O texto taciteano apresentou as pressões de Nero sobre Sêneca para que voltasse atrás em seu propósito (Anais XIV, LVI $)^{48}$.

Em 65, Nero foi informado sobre a conjuração chefiada por Pisão. Lucano, sobrinho de Sêneca, citou o nome do filósofo como integrante do movimento. O princeps, na ocasião, condenou Sêneca à morte, por temer que se tornasse imperador. Nero sobreviveu por mais três anos e em 68, durante uma sedição, apunhalou-se - ou é apunhalado - e perde a vida, pondo fim à dinastia Júlio-Claudiana.

${ }^{48}$ Sêneca no tratado $A d$ Serenum de Otio defendeu o afastamento da política frente à violência e à corrupção. Esta obra, escrita por volta de 61, indica-nos o afastamento de Sêneca da política. De acordo com suas palavras: "se a República é demais corrompida para que se possa auxiliá-la, se é lançada em trevas por males, não se sacrificará o sábio em esforços supérfluos nem tentará ser útil em vão" - "si res publica corruptior est quam ut adiuuari possit, si obscurata est malis, non nitetur sapiens in superuacuum nec se nihil profuturus impendet" ( $A d$ Serenum de Otio III, 3). 


\section{Concepção filosófica}

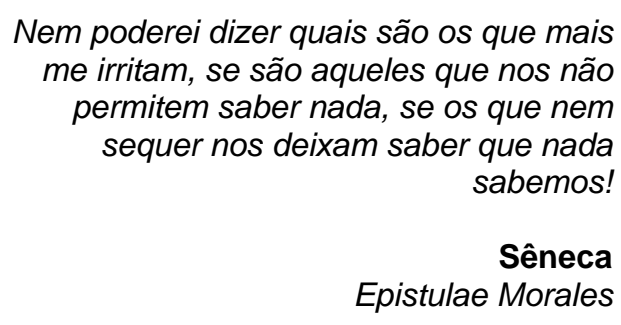

Sêneca, quando jovem, estudou Gramática, Retórica e Filosofia. O mentor de Gramática ensinou-lhe a Língua e a Literatura Latina, além de noções em História e Geografia. O conhecimento de Retórica foi ministrado pelo próprio pai e era uma disciplina imprescindível por se constituir em um instrumento de política.

Cabia ao pedagogo incentivar a eloqüência política e judiciária. As declamações eram divididas por duas modalidades: a suasoria e a controuersia. A primeira era o exercício declamatório político, a segunda, a prática da causídica. Ambas seguiam o mesmo princípio: o rhetor propunha ao aluno um problema e este desenvolvia argumentos sobre temas, geralmente imaginários, que destoavam da legislação romana.

De acordo com o filósofo, os responsáveis pelo ensino direcionavam os aprendizes a abordagens meramente eruditas, sem valor prático (Epist. Mor. 106, 11-12). O conflito existente entre a Filosofia e a Retórica decorria do fato de que o rhetor privilegiava o efeito do discurso em situações, muitas vezes, inexistentes no cotidiano do homem. A filosofia que foi defendida por Sêneca pretendia ultrapassar os limites da eloqüência, para alcançar a prática da uirtus. De acordo com o pensador, o indivíduo devia ocupar-se de "temas mais válidos, que trato daquilo que me tranqüiliza o ânimo, que me observo a mim mesmo antes de observar o universo" (Ego quidem potiora illa ago ac tracto, 
quibus pacatur animus, et me prius scrutor, deinde hunc mundum) (Epist. Mor $65,15)$. O homem deveria retirar os preceitos da filosofia (Epist. Mor. 48, 7).

Tais reflexões estavam alicerçadas na escola estóica, fundada por Zenão de Cítio em 336 ou 264 a.C., em Atenas; entrando em Roma na passagem do século III para o século II a.C., por meio de Panécio e Possidônio. Tradicionalmente, o estoicismo se divide em três períodos: estoicismo antigo (séculos III e II a.C.), no qual essa filosofia se constitui pelas contribuições de Zenão de Cítio (332-262 a.C.), Cleantes de Assos (312-232 a.C.) e Crisipo de Sólis (272- 204 a.C.); estoicismo médio (séculos II e I a.C.), representado por Panécio (185-180 - 110-100 a.C.) e Possidônio (140-130 59-40 a.C.), que introduziram o estoicismo em Roma; e o estoicismo romano ou imperial (até o século II d.C.), ligado a quatro nomes: Sêneca, Musônio Rufo (30 até o final do século I d.C.), Epiteto (50-125/130) e Marco Aurélio (121-180) 49. No livro De Tranquilitate Animi, Sêneca confirmou a influência dos estóicos quando escreve: "disposto, inexperiente, sigo Zenão, Cleantes, Crisipo" "Promptus, imperitus, sequor Zenona, Cleanthen, Crysippum" (De Tranquillitate Animi I, 11).

Essa assertiva continha uma certa ironia: Sêneca ainda que estóico, em alguns momentos, discordava de seus representantes, como era o caso de um excerto em que criticou a proposição de Posidônio sobre as técnicas de construção (Epist. Mor. 90, 7). Sêneca fez, então, o seguinte questionamento: "Foi a filosofia que levou à edificação de blocos habitacionais em andares, para

\footnotetext{
${ }^{49}$ Para maiores detalhes sobre o estoicismo: SANTOS, Ronildo Alves. Sobre a virtude estóica. Campinas: Unicamp, 2002 (Dissertação de Mestrado); BRAREN, Ingeborg. Da Clemência de Sêneca. São Paulo: FFLCH/USP (Dissertação de Mestrado), 1985; GAZOLA, Rachel. O ofício do filósofo estóico: o duplo registro do discurso da stoa. São Paulo: Loyola, 1999; MORTUREUX, Bernard. Les idéaux stoïciens et les premières responsabilités politiques: le "De Clementia". Aufstieg und Niedergang der Römischen Welt, Berlin, II, 36, 3, 1970; NOVAK, Maria da Glória. Estoicismo e epicurismo em Roma. Letras Clássicas, São Paulo, № 3, 1999.
} 
pôr em grave perigo a segurança dos moradores"? (Philosophia haec cum tanto habitantium periculo imminentia tecta suspendit?) (Epist. Mor. 90, 8) ${ }^{50}$.

Aos olhos de Sêneca, a filosofia era o amor, o impulso pela sabedoria que se definia pelo bem supremo do espírito humano. Ainda que existissem várias maneiras de definir filosofia, o pensador a interpretava como sendo o estudo da virtude. Filosofia e virtude eram, portanto, inseparáveis (Epist. Mor. 89, 8).

Sêneca optou por uma filosofia Moral que se fundamentava na arte do bem viver e morrer. "É ela que nos ensina a honrar os deuses e a amar a humanidade, a reconhecer o império dos deuses e a tratar os homens como irmãos" (Haec docuit colere divina, humana diligere, et penes deos imperium esse, inter homines consortium) (Epist. Mor. 90, 3). Exigia-se do indivíduo uma experiência moral, uma consciência de interioridade espiritual que aprofundava os ensinamentos recebidos dos mestres e proporcionava, igualmente, uma nova vida.

O filósofo queria atingir a conduta prática, por esta reger as atividades externa e interna do ser humano. O indivíduo, a partir de constantes avaliações, obedeceria à ordem natural dos deuses, evitaria excessos alimentares e aliar-se-ia a interesses honestos (De Vita Beata XX). Neste caso, o exame de consciência foi uma prática realizada pelos estóicos, como forma de alcançar o bem e de obter o aperfeiçoamento de si mesmo, seus atos e os seus pensamentos. (De Clementia Pr. I, 1). De acordo com o filósofo: "todos pensamos no que estamos para fazer e mesmo isto raramente, mas não

\footnotetext{
${ }^{50}$ Pierre Grimal (1989) enumerou vários elementos filosóficos de Sêneca em discordância com a escola estóica, como por exemplo, a grandeza da alma que era a mais bela das virtudes, não porque provocava admiração dos homens, como pensou Panécio e Cícero, mas por elevar efetivamente a alma dos homens até a divindade (p. 1975).
} 
atentamos no que já fizemos quanto afinal às decisões do futuro estão dependentes do passado" (Quid facturi simus, cogitamus, et id raro; quid fecerimus, non cogitamus: atqui consilium futuri ex praeterito venit) (Epist. Mor. $83,2)$.

O indivíduo capaz de se auto-avaliar tinha por fim a sabedoria, que representava o equilíbrio, pois "o sábio vive em plena alegria, contente, tranqüilo, imperturbável; vive em pé de igualdade com os deuses" (sapiens ille plenus est gaudio, hilaris et placidus, inconcussus; cum diis ex pari vivit) (Epist. Mor. 59, 14). Para Sêneca, este cidadão estava capacitado a escolher o mais sensato, sem sentir temor pelo que rejeita, nem admiração pelo que escolhe. Basta que tivesse uma alma nobre e firme (Epist. Mor. 31, 06).

O sábio encontrava-se acima dos homens comuns e ao lado dos deuses, agindo sempre de forma perfeita, por sua condição (Epist. Mor 59, $14)^{51}$. De acordo com Sêneca, "do mesmo modo, o sábio é um artista a domar os males: a dor, a miséria, a degradação social, a prisão, o exílio - objetos de terror geral! - tornam-se mansos se chegam junto dele" (sic sapiens artifex est domandi mala. Dolor, egestas, ignominia, carcer, exsilium, ubique horrenda, quum ad hunc pervenere, mansueta sunt) (Epist. Mor. 85, 41).

Sêneca e a stoa diferenciavam o sábio do insensato também por motivos educativos. Pretendiam mostrar ao homem comum aquilo que acreditavam ser o certo (cf. GAZOLLA, 1999). Dessa forma, o homem sapiente

\footnotetext{
${ }^{51}$ Aos olhos do filósofo, existiam três classes de homens: a primeira abarcava aqueles não sapientes, embora já estivessem próximos do objetivo. Eram os que se libertaram das paixões e dos vícios e adquiriram conhecimentos necessários para este fim, porém a confiança permanecia abalável. Os de segunda classe conseguiam se libertar das principais enfermidades da alma e das paixões, mas não as gozavam de um estado de perfeita tranqüilidade. Ainda estavam sujeitos a retroceder ao estado precedente. Finalmente, o homem de terceira classe livrou-se de numerosos vícios, mas se sujeitava à ira, à ambição, ao temor como a dor física (Epist. Mor. 75, 9/15). O ideal a ser obtido era ser dono de si próprio, segundo os preceitos do pensador, a ataraxia era um bem inestimável (Epist. Mor. 75, 18).
} 
estava, de acordo com Sêneca, autorizado a educar e direcionar os súditos, para que pudessem conquistar o equilíbrio da alma. Como um ser superior às imperfeições humanas, estava apto a governar, principalmente, por ter nascido "para a assistência comum e para o bem público, do qual dará a cada um a sua parte" (in commune auxilium natus ac bonum publicum, ex quo dabit cuique partem) (De Clem. II, IV, 3).

Isso se devia por considerar os vícios como fatores de desequilíbrio da ordem, por causarem o término das leis naturais e acarretarem conseqüências desastrosas, tanto para o indivíduo quanto para a sociedade. Como sugere Jean Brun (1962),

O estoicismo não começou definindo uma sabedoria natural para se perguntar em seguida como podiam originar as paixões: comprovou que os homens eram apaixonados e insensatos e procurou buscar uma sabedoria, uma sabedoria que se constitui numa reconciliação com o mundo e os homens (...) ao contrário, se perguntou como mostrar ao homem em desacordo consigo mesmo e com os outros que o caminho do equilíbrio é possível e que a natureza o oferece (p. 48).

A piedade, a inveja, o ódio, a rivalidade, a cólera, o amor, o ressentimento eram contradições irracionais da alma. Sêneca propunha o combate desses vícios pelo exercício da virtude, o domínio dos sentimentos e o enfrentamento das vicissitudes com tranqüilidade, como sendo o caminho para que se atingisse a felicidade. De acordo com seu pensamento,

a vida feliz é, por conseqüência, aquela adequada à natureza e alcançável em primeiro lugar pelo espírito sadio e perpétuo possuidor desta saúde; em segundo lugar pelo espírito forte, vigoroso e além de tudo paciente e apto a assistir todas provações, solicito - mas sem titubeios - aos cuidados do corpo, dedicado a procurar outras benesses que alegram a vida, sem inebrios, gozando os dons da fortuna sem escravizar-se a ela. (Beata est ergo uita conueniens naturae suae, quae non aliter contingere potest quam si primum sana mens est et in perpetua possessione sanitatis suae, deinde fortis ac uehemens, tunc pulcherrime patiens, apta temporibus, corporis sui pertinentiumque ad id curiosa non anxie, tum aliarum rerum quae uitam instruunt diligens sine admiratione cuiusquam, usura fortunae muneribus, non seruitura) (De Vita Beata III, 3). 
Felicidade, portanto, era o homem "dotado de reto juízo; feliz que se contenta com seu estado e condição qualquer que seja e aprecie o que é de sua posse; feliz quem confia à razão a gerência de toda a vida" (est iudicii rectus; beatus est praesentibus qualiacumque sunt contentus amicusque rebus suis; beatus est is cui omnem habitum rerum suarum ratio commendat) (De Vita Beata VI, 2). O único dever de um homem virtuoso era possuir harmonia de pensamento e de ações com as leis da natureza, quer dizer, o indivíduo tinha por obrigação extinguir as avaliações externas à alma que era a apreciação do outro pelas vestes, eloqüência, autoridade e poder (De Vita Beata II).

A virtude era um bem que se fundava apenas em uma e mesma coisa: a presença do bem em uma pessoa, a perfeição comum com o todo. A uirtus era, portanto, una, total. Em outras palavras, não se era mais ou menos virtuoso. Todas as virtudes estavam intimamente ligadas entre si e quem se colocava à disposição da prudência estava intimamente munido de razão, temperança com a ordem e com a convivência, com a equidade e com a benevolência, com a coragem, com a firmeza e com a constância (BRUN, 1962, p. 46) $)^{52}$. A virtuosidade era responsável pela condução do indivíduo às ações de autocontrole, prudência, temperança, moderação e constância que influíam no todo social.

\footnotetext{
52 Segundo Voelke (1973), Sêneca posiciona certas virtudes como parte da vontade. Citemos: "Sêneca não se limita em descrever a identidade da vontade em seu aspecto positivo e da virtude em seu sentido mais amplo. Ele traz também de uma maneira explícita certos aspectos particulares em relação à vontade. É o caso da generosidade, da bondade e do reconhecimento, da clemência" (p. 183).
} 


\section{Corpus documental}

Trabalhamos com o conjunto da obra de Sêneca a partir de um recorte temático e não cronológico. A escolha se deve a dois motivos: o primeiro refere-se à dificuldade de as obras senequianas não possuírem uma datação precisa. Em sua quase totalidade, as datas de que dispomos são apenas prováveis. Infelizmente não é fácil ter um rigor cronológico. Segundo, não percebemos uma transformação perceptível na construção senequiana em se tratando dos setores subalternos. Como nosso objetivo é analisar a compreensão de Sêneca destes setores na sociedade romana, então, consideramos plausível tratar suas obras sem levar em conta a questão de como a perspectiva de Sêneca teria ou não se alterado ${ }^{53}$.

Conhecemos quatorze obras filosóficas, uma sátira menipéia e nove tragédias escritas por Sêneca ${ }^{54}$, além de uma série de fragmentos e setenta e sete epigramas com autoria discutível e datação incerta. Os diálogos a que

\footnotetext{
${ }^{53}$ Partilhamos da argumentação de Faversani (2000) que afirmou não ser "possível perceber uma alteração significativa, derivada de uma pressuposta mudança de visão do autor, no que se refere aos mecanismos utilizados por Sêneca para apreender a sociedade em que viveu. Como nosso objetivo de investigação é justamente o padrão de ordenação social em Sêneca, consideramos ser razoável tratar suas obras sem estabelecer como, ao longo do tempo, a perspectiva de análise desse autor teria se alterado" (p. 17).

${ }^{54}$ Há nove tragédias, sem datação segura, que têm por base o modelo das tragédias gregas, além da influência latina, sobretudo Ovídio e Rufos, em suas composições. São elas: Hercules Furens (A Loucura de Hércules), Troades (As troianas), Phoenissae (As Fenícias), Medea (Medeia), Phaedra (Fedra), Oedipus (Édipo), Agamêmnon (Agamemnom), Thyestes (Tiestes) e Herculens Oetaeus (Hércules no Eta).

Há, igualmente, a tragédia Otávia que foi considerada apócrifa pela maioria da crítica especializada. "Escrita possivelmente no primeiro século de nossa era, na época dos Flávios, a pretexta Otávia foi por vezes atribuída a Sêneca por ter sido encontrada em manuscritos que continham as tragédias senequianas" (CARDOSO, 2005, p. 27). Além disso, devemos salientar a repressão às manifestações do pensamento em um momento de intensa censura e punição por parte dos imperadores contra escritores. Sêneca, dificilmente, escreveria um texto com intensas críticas a Nero, estando ainda vivo, como foi o caso da tragédia Otávia. Em outras obras como Apocolocyntoses e De Ira, o autor demonstrou insatisfação contra os imperadores Cláudio e Calígula, no entanto, decorrem no post mortem; caso contrário, estaria exposto a sanções como crime de lesa majestade. Consultar: ROYO, M. L'Octavie: entre Néron et les premiers Antonins. Revue des Études Latines, Paris, Les Belles Lettres, 61 année, 1983; NÉRAUDAU, Jean-Pierre. Néron et le nouveau chant de Troie. Sprache und Literatur (Literatur Der Julisch-Claudischen), 1985. p. 2033/2045.
} 
tivemos acesso são os denominados Dialogi, encontrados no códice Ambrosiano.

Apresentaremos esses textos de acordo na ordem em que aparecem no manuscrito: De Prouidentia (não se conhece a datação), De Constantia Sapientis (escrito entre os anos 47 e 62 d.C.), De Ira (composição realizada no início do principado de Cláudio, antes de 52 d.C.), Consolatio ad Marciam (datável de 39 ou 40 d.C.), De Vita Beata (produzida depois de 58 d.C.), De Otio (estima-se ser anterior a 62 d.C., caso o tratado seja realmente dedicado a Serenus, o que não é evidente), De Tranquilitate Animi (sem datação), De Brevitate Vitae (composto provavelmente em 55 d.C.), Consolatione ad Polybium (escrito em 43 d.C.), Consolatione ad Helviam Matrem (composta nos anos de exílio).

Além desses tratados do códice Ambrosiano, há quatro manuscritos em prosa. São eles: De Clementia (redigido na passagem de 55 para 56 d.C.), De Beneficiis (a datação é incerta, mas estima-se que foi escrita entre 54 e 64 d.C.), Epistulae Morales (últimos anos de sua vida) e Questiones Naturales (últimos anos de sua vida). Temos, igualmente, uma obra de outro gênero que foi atribuída a Sêneca, a sátira menipéia Diui Claudii Apocolocyntoses escrita após a morte de Cláudio, em 54 d.C..

Sobre esses textos especiais em suas particularidades, passamos a fazer de forma sucinta observações sobre conteúdo. 


\section{Síntese das obras}

Faremos uma discussão sucinta sobre os temas gerais que foram apresentados por Sêneca. No entanto, centralizaremos somente as obras que utilizamos como fonte documental, para o desenvolvimento da pesquisa. São elas: Diui Claudii Apocolocyntoses, De Prouidentia, De Constantia Sapientis, De Ira, De Vita Beata, De Otio, De Tranquilitate Animi, Ad Paulinum de Breuitate Vitae, Ad Marciam de Consolatio, Consolatio ad Helviam, Ad Polybium de Consolatio, De Beneficiis e Epistulae Morales. Para tanto, dividiremos o texto em três partes: sátira menipéia, dialogi e os tratados em prosa.

\subsection{Diui Claudii Apocolocyntoses:}

A sátira menipéia recebeu essa denominação pelo fato de o seu criador chamar-se Menipo; caracterizava-se por ser uma mistura de prosa e verso, cuja finalidade transcorria os caminhos da estética e da paródia. Era composta por historietas de tom popularesco, com fundo cômico, que criticavam instituições ou pessoas. Vizinha da comédia, do humor, pressupunha uma atitude ofensiva, mesmo quando dissimulada: o ataque e a insatisfação perante o estabelecido eram as suas marcas referenciais.

Este gênero literário retratava uma tradição romana em que pessoas falecidas, que ocupavam um lugar de destaque público, eram censuradas. Cláudio foi referido com muito sarcasmo, pois o título Apocolocyntoses retratava a transformação deste em abóbora. A narrativa, no entanto, não comentou essa metamorfose, donde nos sugere uma depreciação de Cláudio, principalmente, pelo fato das curcubitáceas, nos países mediterrâneos, serem 
sinônimos de estupidez. Logo, tornava-se evidente a figura do imperador ser associada à loucura, à imbecilidade.

A sátira revelava normas morais relativamente claras nas quais eram medidos o burlesco e o absurdo. Esta requeria uma fantasia, um conteúdo que o leitor reconhecesse como grotesco, e pelo menos um padrão moral implícito, sendo o último essencial, numa atitude combativa para a experiência (FRYRE, 1973, pp. 219-20).

A Apocolocyntoses, escrita por volta de 54 d.C., após a morte de Cláudio, preenchia tais exigências. A sátira relatava a trajetória fantástica seguida pela alma de Cláudio, post mortem, com uma série de eventos que se realizavam em variadas localizações. Como afirmou Ingeborg Braren (1995), a sátira foi dividida em quatro fases:

1. In terris (II, 1 - IV, 3): Discutiu-se sobre o destino de Cláudio e Mercúrio, mensageiro de Júpiter, rogava a Cloto que eliminasse a vida deste indivíduo que em vida nunca pensaram que tivesse nascido (Apoc. III, 2).

2. In caelo (V, 1 - XI, 6): Os deuses discutiam sobre a possibilidade de Cláudio, já morto, tornar-se deus ou não. O personagem Augusto condenava a possibilidade da deificação de um homem que em vida não tinha nenhum tipo de escrúpulos, um indivíduo com características viciosas e ridículas. Cláudio era um governante tirânico assim como Calígula.

3. Ad Inferos (XII, 1 - XII, 3): Cláudio e Mercúrio vislumbravam o enterro que seguia pela via Sacra. Percebiam uma contagiosa emoção, "era uma alegria, uma felicidade universal: o populus romanus passeava sentindose livre" (Omnes laeti, hilares; populus romanus ambulabat tanquam líber) (Apoc. XII, 2). 
4. In inferiis: Cláudio foi levado, em represália, ao tribunal de Éaco, e sendo um "homem justo, pronuncia o veto e condena o réu, depois de ter ouvido somente à acusação" (homo iustissimus, uetat et illum, altera tantum parte audita, condemnat) (Apoc. XIV, 2). "Então, Éaco Ihe designa a brincar com os dados, mas usando um copo sem fundo. Começa, imediatamente: corre atrás dos seus dados que sempre lhe fogem; e não pode concluir nada" (Tum Aecus iubet illum alea ludere pertuso fritillo. Et iam coeperat fugientes semper tesseras quaerere et nihil proficere) (Apoc. XIV, 5).

O fim de Cláudio não era nada animador; continuou sendo o que foi em vida: um funcionário inferior que auxiliava os inquéritos e processos especiais. Cláudio voltou a ser escravo de seu próprio liberto. "César o dá de presente a Éaco; e Éaco o entrega ao seu liberto Menandro, para que faça dele um esbirro na instrução dos processos" (Caesar illum Aeaco donat. Is Menandro liberto suo tradidit, ut a cognitionibus esset) (Apoc. XV, 2).

4.2. Dialogi: De Prouidentia, De Constantia Sapientis, De Ira, De Vita Beata, De Otio, De Tranquilitate Animi, De Brevitate Vitae, Consolatio ad Marciam, Consolatione ad Polybium e Consolatione ad Helviam Matrem.

Os tratados De Prouidentia e o De Constantia Sapientis foram elaborados como forma de aconselhamentos que pretendiam, através da ponderação e da sabedoria, ensinar uma vida fundamentada na razão.

Sêneca, na primeira obra, direcionou as discussões a Lucílio e explicou os males que atingiam os bons e como o amigo deveria guiar-se frente às dificuldades. Lucílio deveria compreender que a divindade "não trata o homem de bem com amenidades, ele o prova, o endurece, prepara-o para si" (bonum uirum in deliciis non habet, experitur indurat, sibi illum parat) (De 
Prouidentia 1, 6). Os bons, enquanto se sacrificam, suam e escalam trilhas

íngremes; os maus, pelo contrário,

se entregam à luxúria e nadam em prazeres, lembra que nós nos deleitamos com a moderação dos filhos e a licenciosidade dos jovens escravos: aquelas são contidas pela mais penosa disciplina, e destes se estimula o atrevimento. (malos autem lasciuire et uoluptatibus fluere, cogita filiorum nos modestia delectari, uernularum licentia, illos disciplina tristiori contineri, horum ali audaciam) (De Prouidentia 1,6).

Podemos considerar o De Constantia Sapientis como complemento do De Prouidentia, pois Sêneca forneceu elementos para que o indivíduo conseguisse passar por transtornos como as ofensas e as injúrias com tranqüilidade, defendendo uma postura firme e inabalável ${ }^{55}$. Sêneca aconselhava que

não se deve entrar em rixas e lutas corporais. Deve-se sair de perto e todas as provocações desse tipo que forem feitas pelos insensatos - e só pelos insensatos podem ser feitas - devem ser ignoradas; e as homenagens e as injúrias do vulgo devem ser consideradas uma coisa só (Non est in rixam conluctationemque ueniendum. Procul auferendi pedes sunt et quidquid horum ab inprudentibus fiet (fieri autem nisi ab inprudentibus non potest) neglegendum et honores iniuriaeque uulgi in promiscuo habendae) (De Constantia Sapientis 19, 1) ${ }^{56}$.

55 Consultar DIJON, Jean-Marie André. Sénèque: 'De Breuitate uitae', 'De Constantia Sapientis', De Tranquilitate Animi', 'De Otio'. Aufstieg Und Nierdergang Der Römischen Welt (ANRW), vol.36.3, 1989.

${ }^{56}$ O filósofo utilizava os recursos de linguagem como metáforas, exemplos e a Setentiae frases curtas com efeitos e que concentravam significados relevantes referentes a sua posição filosófica. Assim como a afirmativa sobre a morte: "a morte consagra aqueles cujo fim é louvado até pelos que o temem" (mors illos consecrat quorum exitum et qui timent laudant) (De Prouidentia 2. 12).

O conceito de metáfora não pode ser definido apenas como "uma substituição de uma palavra por outra, quando há uma relação de similaridade entre o termo de partida (substituído) e o de chegada (substituinte)" (FIORIN, 2001, p. 86). Segundo Fiorin, "essas definições são insuficientes, pois a metáfora e a metonímia são procedimentos discursivos de constituição do sentido. Nelas o narrador rompe, de maneira calculada, as regras de combinatória das figuras, criando uma impertinência semântica, que produz novos sentidos. Assim, metáfora e metonímia, não são a substituição de uma palavra por outra, mas uma outra possibilidade, criada pelo contexto, de leitura de um termo" (Ibidem).

Temos aqui: "ele, com certeza, vai tentar, se a necessidade o chamar, e vai abrandar o porteiro, seja que for, como se faz com um cão feroz, ao qual se joga comida" (Ille uero, si res necessaria uocabit, experietur et illum, quisquis erit, tamquam canem acrem obiecto cibo leniet) (De Constantia Sapientis 14.2). Neste excerto, Sêneca utilizou a metáfora do cão feroz, para dizer que o sábio teria tranqüilidade ao lidar com um porteiro, que lhe cobra uma determinada quantia para adentrar a casa. Temos, portanto, a figura do "cão feroz" que exprime a ferocidade do escravo que é abrandada facilmente, basta que o visitante dê dinheiro, assim como o cachorro que é abrandado com algum alimento. 
A resposta às injúrias estaria na prática da uirtus que representava o verdadeiro estado de felicidade. Sêneca, no tratado De Vita Beata direcionado a seu irmão Galione, dissertou sobre o único dever do indivíduo: ser feliz. O que transcorrerá, na realidade, um tratado acerca da conduta dos seres frente à vida. Devia-se, primeiramente, decidir onde e como ir, ajudado por uma pessoa experiente e conhecedora do caminho a ser trilhado (De Vita Beata I). Aos olhos de Sêneca,

nada é pior que escutar os rumores públicos, considerando justo o que a maioria aprova e imitando o modelo de comportamento da massa, vivendo não segundo a razão, mas pelo conformismo. É este o motivo das aglomerações de pessoas que se esmagam uns aos outros. (Atqui nulla res nos maioribus malis implicat quam quod ad rumorem componimur, optima rati ea quae magno assensu recepta sunt, quodque exempla nobis multa sunt nec rationem sed ad similitudinem uiuimus. Inde ista tanta coaceruatio aliorum super alios ruentium) (De Vita Beata I, 3).

A resposta à felicidade estaria na recusa de uma busca desenfreada da riqueza e do poder, inclinando-se ante as autoridades, a escravização pelo luxo e pelos dons da fortuna. Para Sêneca, viver de acordo com a natureza era fundamentar-se na honestidade, no conhecimento de si, no desdém pelos prazeres, na contínua serenidade e na alegria que posicionava o homem feliz distante daqueles que se posicionam no mesmo plano das bestas (De Vita Beata V, 2) ${ }^{57}$.

Um outro recurso retórico muito comum nas obras senequianas consiste nos exempla, que servem como modelo explicativo para que o leitor reconheça, mais facilmente, o objetivo de seu discurso. Como é o caso de Catão (De Constantia Sapientis, Epistulae Morales) que aparece como símbolo de retidão, de honestidade e possuidor dos valores morais tradicionais, muito apreciado pelos estóicos. Há igualmente os exemplos a serem seguidos e exemplos a serem evitados: como é o caso de Calígula (De Clementia, Apocolocyntoses, De Constantia Sapientis) e de Cláudio (De Clementia, Apocolocyntoses), etc...

${ }_{57}$ Como sugeriu Michel Foucault (1998), a ação moral é essencialmente uma conduta. De acordo com suas palavras: "uma ação moral tende à sua própria realização; além disso, ela visa, através dessa realização, a constituição de uma conduta moral que leva o indivíduo, não simplesmente a ações sempre conformes aos valores e às regras, mas também a um certo modo de ser característico do sujeito moral” (p. 28). 
Tais idéias baseavam-se no ideal estóico que propunha a busca permanente da virtude e, por conseqüência, no afastamento das paixões que encolerizavam os indivíduos, afastando-os do autodomínio. Sêneca, quando compôs De Tranquilitate Anima, oferecido a Sereno, amigo e discípulo, discutiu a relação dos males que sobrevêm ao homem (I e II) e a indicação dos remédios proporcionados pela filosofia (III, XVII $)^{58}$.

Sêneca também desenvolveu temas sobre a inquietação e a instabilidade da alma, discutiu a participação na vida pública, a escolha dos amigos, os maus efeitos da riqueza, como se comportar na infelicidade, os inconvenientes das situações elevadas e a indiferença do sábio em relação aos acontecimentos exteriores, pois o indivíduo deveria praticar a simplicidade, alternar a solidão e a vida social, alternar o trabalho e o divertimento ( $A d$ Serenum de Tranquilitate Animi VI, 1/2).

Sêneca, no diálogo imaginário com Sereno, refletiu sobre a prática do ócio sem deixar de ser estóico, além disso, considerava-o útil à sociedade. Neste mesmo tratado, De Otio, o filósofo fez uma abordagem sobre as diferenças doutrinais entre epicurismo e estoicismo, reafirmando argumentos precedentes sobre a obrigatoriedade do ócio para um estóico. De acordo com o pensamento senequiano, quando se é útil aos demais, serve-se aos interesses gerais, pois quem se corrompe não prejudica somente a si próprio, mas àqueles que estão no processo de aperfeiçoamento (De Otio III, 5).

\footnotetext{
${ }^{58}$ Angélica Chiapetta (1999) propôs que o tratado De Tranquilitate Animi "pode ser visto como um 'diálogo epistolar' entre Sêneca e seu discípulo Sereno (nome interessante para um interlocutor nesse diálogo) O diálogo filosófico simula uma conversa entre pessoas interessadas em discutir; a epistulae uma carta-resposta de um mestre a seu discípulo que, trazendo um assunto para observação, acaba por receber algum tipo de preceito de mestre. A participação do discípulo fica aqui implícita, sendo percebida apenas por alguma referência do mestre" (p. 25).
} 
Há, portanto, uma continuidade nas reflexões desenvolvidas nas obras acima com o tratado Ad Paulinum de Brevitate Vitae, dedicado a Paulino. Este ocupava um alto cargo burocrático imperial, responsabilizava-se pela distribuição do trigo em Roma. Foi exortado pelo filósofo a abandonar a vida pública para que se dedicasse ao ócio literário e filosófico. De acordo com a reflexão de Sêneca: "que negligência tão louca a dos mortais, de adiar para o qüinquagésimo ou sexagésimo ano os prudentes juízos, que a partir deste ponto, aos quais poucos chegaram, querer começar a viver?" (quae tam stulta mortalitatis obliuio in quinquagesimum et sexagesimum annum differre sana consilia et inde uelle uitam inchoare quo pauci perduxerunt?) (Ad Paulinum de Brevitate Vitae III, 5).

O luxo, a riqueza, a sede de poder, a busca pela beleza eram sinônimos, na concepção de Sêneca, de má gerência na vida (Ad Paulinum de Brevitate Vitae II, 1). Os homens deixam de existir por calcularem o seu tempo apenas pelo relógio, deixando de lado a vida interior (Ad Paulinum de Brevitate Vitae VII, 10).

O desperdício de tempo que significava o não direcionamento dos homens aos estudos filosóficos e, por conseqüência, as vias responsáveis pelo afastamento das virtudes como moderação, constância, tranqüilidade da alma, prudência, clemência, justiça, etc; direcionavam os homens, na ausência destas, a ações como a tirania e a cólera. Sêneca, não sem motivo, redigiu o tratado sobre a ira, dedicado a Aneu Novato, seu irmão mais velho.

No tratado intitulado $D e ~ I r a^{59}$, o pensador afirmava que a ira era um dos vícios nocivos à humanidade, definida como uma loucura breve, atingia

\footnotetext{
59 Segundo J. F. Lahille (1989), o De Ira foi um tratado do bom governante. De acordo com suas palavras: "encontraremos aí mais precisamente um tratado do bom juiz, bonus iudex, pois
} 
indivíduos, Estados e até mesmo animais. Apresentavam, segundo Sêneca, uma fronte sombria, o rosto turvo, mãos irrequietas, mudança de cor, respiração ofegante, que eram os sinais idênticos à ira $(D e \operatorname{Ira} I, I, 1) .0$ pensador considerava seus danos e efeitos ao gênero humano como massacres, envenenamentos, crimes cometidos individualmente ou contra cidades, extermínios de povos, chefes vendidos como escravos (De Ira I, II, 2). A ira não era, por natureza, nem nobre e nem útil; sua moderação significava apenas um mal moderado. Eliminando-a, todas as virtudes apareceriam no homem.

Sêneca, de modo geral, refletiu sobre a relevância das virtudes para o crescimento individual e coletivo, independentemente do gênero que constitui as obras, sejam tratados, sátira ou cartas, o filósofo defendeu a virtude como elemento imprescindível.

Podemos afirmar, nesse sentido, que as cartas consolatórias eram, uma espécie de "farmácia moral", o consolador preocupava-se em socorrer àqueles que sofriam, "mesmo sem serem solicitados, com argumentos prévios e cuidadosamente preparados para combater os males que mais afligiam o homem, como a doença, a velhice, a pobreza, o exílio e, o maior deles, a morte" (VAN RAIJ, 1999, p. 14).

Em linhas gerais, as consolações estavam submetidas a uma determinada estrutura: introdução que se constituía pela enunciação do mal que o consolador pretendia tratar e os remédios; em seguida, tratava da aflição do sujeito, voltando-se para as causas de sua aflição e, enfim, concluía. Como sugeriu C. F. Mendonça (1999), Sêneca "procura não só expor sua filosofia e,

a maioria de seus conselhos determina a maneira que o príncipe deve, sem paixão nem precipitação, promover a justiça" (p. 1618). 
ainda, captar a visão de mundo desta, para assim melhor chegar ao seu espírito" (p. 15). Nas consolações, a dor foi apresentada como um mal universal, embora tenha trabalhado de forma diferenciada em cada uma das obras. Na Consolatio ad Helviam e Polybium, o filósofo analisou a dor, sem perder de vista a sua própria dor, a de estar no exílio. Trataremos primeiramente da Consolatio ad Marciam.

1. Consolatio ad Marciam: essa consolação foi dirigida a Márcia, uma aristocrata romana e filha do historiador Aulo Cremúcio Cordo. Estremecida com a morte de seu pai, foi duramente atingida com o falecimento de seu filho Mitílio, provocando-Ihe uma dor tão intensa que se refugiou em si mesma, recusando-se a qualquer consolação.

Passado três anos do acontecido, Sêneca resolveu escrever uma carta consolatória, esperando que seus argumentos servissem como um remédio para a alma de Márcia. Encontravam-se temas sobre o valor e a instabilidade da vida, a aceitação da morte, tendo em vista a inevitabilidade desta. Utilizou igualmente exemplos de mulheres, como Lívia, esposa de Augusto, que suplantaram a dor. O filósofo utilizou também a imagem de seu pai Cremúcio, enaltecendo as virtudes e grandeza da alma. Assim como deveria admirar a grandeza do filho pelas suas virtudes, não pelos anos, pois havia vivido o suficiente (Consolatio ad Marciam XXIV, 1).

2. Consolatio ad Helviam: Sêneca escreveu esta consolação para apaziguar as dores de sua mãe que sofria demasiadamente com seu exílio na ilha de Córsega (Consolatio ad Helviam II, 4). Queria transmitir tranqüilidade frente a esta situação e que, contrariamente à crença comum, o exílio não lhe fazia mal. Era insano Hélvia afligir-se por ele. 
O filósofo declarou que qualquer indivíduo, assim como o exilado, deveria ter como companheira a virtude e esta acalentaria toda a amargura causada pela fortuna. Aos olhos do pensador, esta situação era, seguramente, uma mudança de lugar. "Para que não pareça que atenuo sua força e suprimo tudo quanto de péssimo traz em si, apontarei as desvantagens desta mudança de lugar: a pobreza, a desonra, o desprezo público" (ne angustare uidear uim eius et quicquid pessimum in se habet subtrahere, hanc commutationem loci sequuntur incommoda: paupertas, ignominia, contemptus) (Consolatio ad Helviam VI, 1).

Sêneca aconselhou a mãe a dedicar-se aos estudos de filosofia como remédio para acalentá-la; para ele, o recurso era suficiente para abrandar a dor de saudade que atingiu Hélvia por sua ausência.

3. Consolatio ad Polybium: a intensa amargura que passava Políbio pela morte do irmão ${ }^{60}$, fez com que Sêneca o incitasse, assim como fez com Márcia, a eliminar o sofrimento: primeiro, a morte era um fato presente na vida de qualquer homem e, em segundo, aproveitava para exaltar as ações de seu irmão, dizendo:

Ninguém sentiu seu poder com ultraje, ele nunca ameaçou alguém se valendo do nome do seu irmão; formara-se segundo o exemplo de tua modéstia e compreendia não só que grande honra, mas também que farto foste para os teus: ele soube suportar a carga. (Nemo potentiam eius iniuria sensit, numquam illi te fratem ulli minatus est; ad exemplum se modestiae tuae fomauerat, cogitabatque quantum tu et ornamentum tuorum esses et onus: suffecit ille huic sarcinae) (Consolatio ad Polybium III, 2).

O que diferencia esta consolação das outras, na concepção historiográfica contemporânea, se refere à intencionalidade de Sêneca. Alguns autores, como Paratore (1987), defendem a pressuposição de que o filósofo

\footnotetext{
${ }^{60}$ Políbio era um liberto de origem grega e influente junto ao Imperador Cláudio. Sua função era transmitir a Cláudio memoriais, requerimentos e súplicas dos cidadãos de toda a parte do Império.
} 
fez um pedido de regresso mediante as mais exageradas adulações ou como Paul Veyne (1985) que sugeriu a consolatio como sendo uma solicitação indireta ao imperador para retornar a Roma, uma súplica em forma de carta aberta (Consolatio ad Polybium XIII, 3). Sêneca, na Consolatio ad Helviam, não sentia o exílio como sofrimento, consolava a mãe afirmando que esta condição não era um mal (Consolatio ad Helviam XI, 5). Na Consolatio ad Polybium, pelo contrário, solicitava indiretamente a Cláudio o retorno a Roma, pelas vias de sua clemência.

Essa alteração de sentidos torna-se relevante, em nossa opinião, pelo fato de o filósofo, independente das considerações inspiradas por motivos pessoais, tenha contribuído com a ideologia imperial, escrevendo (anterior ao tratado De Clementia), o retrato do príncipe ideal que se fundamentava na clemência como modelo de governabilidade (LAHILLE, 1989, p. 1615).

Passemos, então, a discutir algumas linhas sobre os tratados: De Beneficiis e Epistulae Morales.

\subsection{Tratados em prosa: Epistulae Morales e De Beneficiis}

Nas Epistulae Morales, Sêneca pretendia conduzir Lucílio, adepto do epicurismo, às teses estóicas. Este ensinamento dividia-se em duas propostas: dominar os princípios teóricos da escola e, por conseqüência, ser capaz de aplicar na vida prática a uirtus. Assim, o amigo se aproximaria tanto quanto possível do ideal de sábio ${ }^{61}$.

Para cumprir tal finalidade, o filósofo construiu a obra a partir de trocas de missivas, que eram realizadas entre Sêneca e o amigo Lucílio. Na

\footnotetext{
${ }^{61}$ Queremos informar a não inclusão da síntese do tratado De Clementia pelo fato de termos discutido-o no item anterior referente à contextualização histórica.
} 
época em que as epistolae foram redigidas, Lucílio desempenhava o cargo de procurador imperial na Sicília (Epist. Mor. 51, 1), "cargo que podemos supor ter sido o culminar da carreira, uma vez que as últimas cartas de Sêneca dão a entender que Lucílio decidira finalmente seguir os conselhos do seu mestre e amigo e entrar também na vida do otium" (CAMPOS, 1991, p. viii).

O filósofo, segundo Braren (1999), optou pelas epistolas por "oferecer uma doutrinação filosófica sem o necessário rigor de um plano de redação de um tratado filosófico" (p. 39) ${ }^{62}$; pela própria natureza do gênero, era necessário ter um emissor e um destinatário, sendo as reflexões discutidas no momento e o conteúdo não necessitava seguir uma ordenação global como em um tratado filosófico.

A estrutura das epistolae era marcada, sobretudo, pela oferta de algum assunto, por ser considerada uma finalidade (cf. BRAREN, p. 42). Sêneca ofereceu as máximas e as sententiae a Lucílio, para encaminhá-lo à sapiência, à capacidade de aproveitar seu tempo com estudos que o encaminhassem à sabedoria. De acordo com suas palavras, "o pior de tudo é o tempo desperdiçado por negligência" (turpissima tamen est jactura, quae per negligentiam fit) (Epist. Mor. 01, 01).

As construções dos temas eram variadas, refletiam questões sobre educação, o sentido e o medo da morte, o valor da amizade, a capacidade de

62 Existe uma enorme discussão sobre a ficcionalidade ou não das correspondências entre Sêneca e Lucílio. J. A. Campos (1991) considerou real a troca de cartas entre os dois, de acordo com sua perspectiva, o "ensino ministrado a Lucílio se processou durante algum tempo apenas por via oral. Mas Lucílio, na prossecução da sua carreira pública veio a ser destacado para a Sicília, e a partir desse momento a direção espiritual só poderia continuar por meio da escrita. O afastamento físico dos dois amigos foi assim a motivação imediata para a produção das cartas" (p. xi). Consultar: CAMPOS, J. A. Segurado e. Introdução. In: Sêneca, L. A. Cartas a Lucílio. Tradução, Prefácio e Notas de J. A. Segurado e Campos, Lisboa: Fundação Calouste Gulbenkian, 1991; GRIMAL, Pierre. Sénèque ou la conscience de l'empire. Paris: Fayard, 1991; PAVIA, G. M. Le 'Epistulae Morales ad Lucilium' di Seneca. Valore letterario e filosófico. Aufstieg Und Niedergang Der Römischen Welt, vol. 36.3, Berlin, 1989. 
suportar o sofrimento, a pobreza, a riqueza, o barulho proveniente das termas, o comércio de produtos, os ofícios, a participação das pessoas no teatro e a troca de favores entre senadores. Sêneca oferecia a Lucílio a possibilidade de tornar-se um homem dominado pela razão e capaz de ser auto-suficiente diante de problemas cotidianos como a fuga de seus escravos ou o convívio com a multitudo (Epist. Mor. 107, 01) ${ }^{63}$. Podemos afirmar, nesse sentido, que Sêneca incluiu elementos informativos sobre os múltiplos aspectos da vida e da civilização romana, a filosofia estóica aparece, justamente, como um elemento de questionamento sobre os valores da sociedade em que se insere.

O tratado De Beneficiis, escrito nos anos finais de sua vida e dirigido a Liberalis, não foge à regra. Sêneca propôs questões vinculadas ao pensamento estóico que resultaram em uma apreciação moral sobre a forma com que eram regidas as relações sociais na sociedade romana. Assim como também não se poderia deixar de pontuar que o filósofo retratou relações concretas e vivenciadas como patrono e cliente, senhor e escravo, pais e filhos, que visava à restauração da confiança nas relações humanas, sublinhando a relevância de se praticar o benefício como elemento imprescindível na constituição social (CHAUMARTIN, 1989, p. 1712).

Aos olhos de Sêneca, os indivíduos não sabiam nem dar nem receber um benefício - quod benificia nec dare scimus nec accipere (De Beneficiis I, I, 1) - por haver interesses imediatos em ambas partes, o que oferecia e aquele que recebia, observava-se o patrimônio e a conduta. Pensava-se, primeiramente, nas vantagens que tal relação proporcionaria, sejam elas econômicas ou aquelas referentes ao status social (De Beneficiis I,

${ }^{63} \mathrm{O}$ autor G. M. Pavia fez um excelente resumo dos conteúdos que são propostos e discutidos por Sêneca em cada epistolae. Consultar: Le 'Epistulae Morales ad Lucilium' di Sêneca. Valore letterario e filosófico. Aufstieg und Niedergang der Römischen Welt, vol. 36.3, Berlin, 1989. 
I, 2 e I, I, 9). De acordo com a perspectiva senequiana, deveríamos praticar benefícios, não empréstimos por interesses (De Beneficiis I. I, 9). Este deveria ser realizado sem esperar nenhum retorno, o fruto do benefício seria 0 reconhecimento imediato pelos notáveis (De Beneficiis I, I, 12).

Tratava-se, sobretudo, de humanizar as relações entre os agentes sociais pelo fato de os benefícios não ocorrerem aleatoriamente e, muito menos, sem interesses pessoais ou públicos. Sêneca defendia que os homens deveriam dar e receber de bom coração (De Beneficiis I, IV, 3). O que teria relevância seria o valor moral dos atos e não o recebimento dos 'presentes' (De Beneficiis I, IX, 1).

Assim como as relações entre escravos e senhores, caracterizadas por Sêneca como um benefício doméstico, quando pautadas pelo relacionamento de proximidade. Tanto um quanto outro recebiam vantagens: 0 escravo ganhava a liberdade, era tratado sem brutalidade, sem avareza, enquanto o senhor recebia afeição, o que Ihe garantia, em algumas situações, a salvação de suas vidas e a resistência às torturas por parte dos escravos (De Beneficiis III, XXII, 1/3 e III, I, 1).

Sêneca retratou a interação entre os agentes sociais de seu tempo por meio de uma dinâmica movimentada e conflituosa, tanto os indivíduos de condição superior, como os de posição inferior, recebiam e contribuíam mutuamente com os benefícios e reagiam, igualmente, a favor ou contra. As relações ocorridas entre os agentes baseavam-se em interesses concretos, diferentemente da interpretação contemporânea de Veyne (1985) que 
propunha sobre a "generosidade espontânea" dos membros da elite que beneficiavam o público (p. 21$)^{64}$.

Como podemos observar, Sêneca elaborou um tratado em que fez críticas à sua sociedade contemporânea, para repensar, sobretudo, as relações entre superiores e inferiores. Os desvios, a arrogância, a avareza, isto é, a corrupção dos valores morais dos notáveis, segundo a sua percepção, encaminhava os inferiores às mesmas aviltesas, provocando a busca de benefícios, única e exclusivamente, pelas vias da quantidade e qualidade do que se recebia, mais do que isso, provocando reações de infidelidade e adulações.

Iniciaremos o capítulo III com a discussão terminológica dos excertos que encontramos no corpus documental, que definem os setores subalternos.

\section{Capítulo III}

\footnotetext{
${ }^{64}$ Sêneca, em linhas gerais, dividiu os sete livros do tratado da seguinte forma: nos dois primeiros livros, o filósofo denunciou as práticas gerais da sociedade no que tange aos benefícios e ensinou, por oposição a eles, a melhor forma de realizar um benefício. Os cinco primeiros capítulos do terceiro livro dividiam-se em três grandes temas: as relações entre patrono e clientes (III, 6 a 17), senhores e escravos (III, 18 a 28) e pais e filhos (III, 29 a 38). O livro quarto foi um debate com os epicuristas sobre as condutas que os indivíduos deveriam seguir frente a qualquer benefício. Este deveria ser realizado pela beleza moral, sem esperança de nenhum proveito. O sujeito que agisse sem interesse sentiria justiça, inocência, grandeza de alma, temperança (IV, XII, 4). Sêneca iniciou o quinto livro com um elogio à generosidade de Liberalis e principiou as discussões causuísticas esboçando a necessidade, o dever e o reconhecimento do benefício (V, IX, 1). O sexto livro foi dedicado a Liberalis (o sétimo também) e abriu com outras questões causuísticas, como o caso do médico que embora recebesse salário, promovia benefícios (VI, XV, 6). Por fim, no sétimo livro, Sêneca fez um guia de condutas sobre um pequeno número de preceitos que deveriam ser assimilados.
} 


\section{A visão sociopd ítica dosstoressubalternosem Sêneca}

1. Um galo sozinho não tece uma manhã: ele precisará sempre de outros galos.

De um que apanhe esse grito que ele e o lance a outro; de um outro galo que apanhe o grito de um galo antes e o lance a outro; e de outros galos que com muitos outros galos se cruzem os fios de sol de seus gritos de galo, para que a manhã, desde uma teia tênue, se vá tecendo, entre todos os galos.

2. E se encorpando em tela, entre todos, se erguendo tenda, onde entrem todos, se entretendendo para todos, no toldo (a manhã) que plana livre de armação.

A manhã, toldo de um tecido tão aéreo que, tecido, se eleva por si: luz balão.

João Cabral de Melo Neto, Tecendo a Manhã, 1994.

\section{Relações sociais: aspectos gerais}

Não prezumam porque têm, Que são, mais do que pobres, nobres, Pois há muitos homens pobres, Mui bem nascidos também. 
Gregrório de Matos A cavalaria da festa das Virgens

Propomos, neste capítulo, uma reflexão sobre a capacidade e as esferas de poder dos chamados setores populares na sociedade romana, referente à primeira metade do século I d.C.. Para tal, optamos por dividir o capítulo da seguinte forma: faremos uma abordagem terminológica, para identificarmos e delimitarmos as palavras que se referiam a estes setores. Analisaremos ainda a prática de ofícios e o cotidiano em ambientes como termas, anfiteatros, ruas e tabernas.

Trabalharemos, no curso dessa discussão, com duas idéias centrais: primeiro, procuraremos, através de Sêneca, mostrar a não ociosidade da plebe. Em segundo lugar, que as relações de poder estabelecidas entre agentes inferiores e superiores podem ser pensadas em termos de contra poderes: o poder de bajular, ou não, um aristocrata, de apoiar, ou não, um imperador, de revoltar-se. Isto se deve ao fato de o poder ser uma relação, para a qual as duas partes são relevantes. O poder não é uma via de mão única. Como sugerimos anteriormente, o poder é uma prática e se estabelece por um mecanismo em que todos os agentes atuam e sentem seus efeitos. Seus variados dispositivos se articulam e se exercem em níveis diferentes da sociedade (cf. FOUCAULT, 1986). Trataremos primeiro da análise terminológica.

\subsection{Terminologia}


Empregamos a expressão "agentes subalternos", como afirmamos no capítulo primeiro, apenas para compreender o que seria essa não elite para Sêneca, pois não é, de fato, utilizado pelo filósofo. Suas categorias são fluidas, ora com significado mais amplo, ora mais restrito. A opinião pública, por exemplo, aparece com muito poder no De Clementia, mas não era exclusividade da plebe ou dos setores subalternos do Império como um todo. Embora os incluísse, abrangia, igualmente, os grupos de "notáveis".

Esses setores, de modo geral, aparecem nas narrativas de Sêneca por termos pejorativos. São eles:

1. Multitudo, inis: refere-se à multidão sediciosa e delinqüente ( $D e$ Clem. Pr., I, 1 e III, XX, 2). Nestas passagens, em especifico, Sêneca imprime um sentido político, alertando Nero acerca dos perigos de uma multidão descontrolada ${ }^{65}$. O termo multitudo é também utilizado, em alguns casos, para exprimir a falta de virtude e, por isso, o indivíduo deve se afastar da multidão. De acordo com suas palavras: "É assim como te digo, não mudo de opinião: fuja das multidões, fuja dos pequenos grupos, fuja mesmo dos indivíduos isolados" (Sic est! non muto sententiam: fuge multitudinem, fuge paucitatem, fuge etiam unum) (Epist. Mor. 10, 1). Nesta situação, segundo a opinião de Sêneca, Lucílio deveria refugiar-se dentro de si, especialmente, se estivesse em contato com a multidão (Epist. Mor. 25, 6). Ainda de acordo com o filósofo, a multidão deveria ser governada pelo princeps, pois "esta imensa multidão, reunida em torno de um só ser vivente, governada pelo seu espírito, dobrada

\footnotetext{
${ }^{65}$ Queremos ressaltar duas observações: no tratado De Clementia, Sêneca apresenta Nero como o representante dos deuses na terra, concedendo-lhe, dessa forma, grandes poderes (De Clementia Pr. I, 2). O imperador, neste ponto de vista, está acima de todos os indivíduos no Império Romano. No entanto, o filósofo sugere a seu tutor que não se esqueça dos cidadãos humildes e poderosos, indicando assim, a constituição de uma elite que aparece representada pelo nome, poder ou sua condição de cavaleiro ou de senador. Enquanto isto, os setores populares são apresentados anonimamente a partir de termos generalizantes como multitudo ou por sua condição jurídica (e.g. escravo, cidadão).
} 
pela sua razão, será oprimida e despedaçada pelas suas próprias forças se não for sustentada pela sabedoria" (Sic haec inmensa multitudo unius animae circumdata illius spiritu regitur, illius rationae flectitur pressura se ac fractura uiribus suis, nisi consilio sustineretur) (De Clem. III, I, 5). O descontrole da multidão além de levá-la à ruína, leva todo o povo romano, o que culmina com o fim da paz romana (De Clem. III, II, 2).

2. Populus, is: aparece em situações que o filósofo discute a questão da morte, todos têm o mesmo destino, até mesmo o povo (Brevit. Vitae VII, 5), ou em passagens que o classifica pela falta de razão (De Vita Beata I, 5) ou com conotações de cunho político, tais como: ruína, fome (Brevit. Vitae XVIII, 5/6), reuniões sediciosas (De Vita Beata I, 4; Ep. Mor. 29, 11). O princeps deveria cativar, sobretudo, o povo (De Clementia III, XI, 4).

Sêneca utiliza a expressão populus, assim como multitudo, não somente para indicar o grupo dos setores subalternos, mas, em sentido geral, significando povo romano e opinião pública, além de aparecerem em abordagens filosóficas (Consolatio ad Helviam V, 6; Epist. Mor. 74, 4) ${ }^{66}$. Vejamos alguns exemplos: não compartilhar com a opinião do povo (De Constantia Sapientis XIV, 4) - é prejudicial o convívio com o povo (Epist. Mor. 7, 2) - aconselha não participar de debates, pois o povo não tem nada a oferecer (Epist. Mor. 7, 9) - em algumas situações, deve-se precaver de todo o povo (Epist. Mor. 14, 7) ${ }^{67}$.

\footnotetext{
${ }^{66}$ Nesta passagem, Sêneca afirmava que não havia nada pior do que a opinião dos vulgares. Citemos in extenso: "nada encontro tão horrível e duro, quanto à opinião de vulgares faria temer" (nihil tam terribele ac durum inuenio quam opinio uulgi minabatur) (Consolatio ad Helviam V, 6).

${ }^{67} \mathrm{Em}$ um dos colóquios de orientação com o Prof. Guarinello, surgiu uma discussão, de extrema relevância, acerca da diferença entre populus e plebs. Esta, segundo Guarinello, seria pelo menos, sob a perspectiva taciteana (Hist. I, 4), um termo mais amplo, enquanto populus (termo associado à legalidade) estaria munido de um sentido mais político. Ambos se oporiam integralmente na narrativa de Tácito, sendo, portanto, classificados por populi e plebs sordida.
} 
3. Plebs, plebis: é associada à mediocridade, ira, guerra, luxuria e prosperidade (De Prouidentia IV, 1; Consolatio ad Polybium VI, 2; Epist. Mor. 104, 31; De Ira III, V, 6). Sêneca afirma em De Prouidentia que a riqueza não é um bem, pelo fato de a prosperidade recair até mesmo sobre a plebe e os talentos medíocres (De Prouidentia IV, 1).

4. Turba, ae: este termo tem um sentido pejorativo que significa insensatez e autodestruição, assim como também uma conotação com interesse desmedido. Na Consolatio ad Polybium, Sêneca alerta o liberto de Cláudio ao fato de que a turba sempre assedia o vestíbulo do outro (Consolatio ad Polybium IV, 2)).

5. Humillis, ignobilis e uulgus: são termos utilizados pelo filósofo com sentido político, majoritariamente, associados à violência (De Clementia III, V, 4; III, XIX, 4) e em alguns casos enfocando aspectos filosóficos (Epist. Mor. 98,1; 114, 12). Encontramos, igualmente, o conceito de publicus com um significado de desaprovação, indicando, de modo geral, o vulgo, o povo e em

No entanto, em Sêneca, está oposição nem sempre acontece ou é evidente. Por algumas razões: primeiro, o significado depende, em grande medida, da contextualização utilizada pelo filósofo. Um exemplo disto são as categorias que aparecem em Sêneca como libertos, gladiadores, prostitutas, mercadores, entre outros. São tratados de maneira pejorativa. Há, entretanto, situações em que o filósofo utiliza a figura do gladiador como metáfora de bravura frente à morte, para mostrar que os indivíduos devem enfrentar as vicissitudes da vida com coragem e com ânimo.

O termo populus, da mesma forma, é utilizado por Sêneca com a mesma maleabilidade. $\mathrm{Na}$ passagem a seguir, populus, por exemplo, tem uma conotação mais política. Citemos in extenso: "É possível poder ser amado pelo povo, quando se ama a virtude? É pelo caminho do mal que se obtém os favores populares. Terás de igualar-se, primeiro, aos populares, que só te favorecerá quando te considerar um dos seus" (Quis enim placere potest populo, cui placet virtus? Mallis artibus popularis favor quaeritur: similem te illis facias oportet: non probabunt, nisi agnoverint) (Epist. Mor. 29, 11). Além deste, populus pode vir associado a termos pejorativos que indicam preferência literária (Epist. Mor. 14, 11) ou paixão pelos jogos gladiatoriais (Epist. Mor. 114, 24/25), entre outros. O que parece notável é que o termo plebs, de modo geral, aparece por um grupo social em si, enquanto populus retrata situações gerais e, nem sempre, um grupo social em específico. Digo isto, pois em algumas passagens populus, assim como turba, uulgus, multitudo podem significar ou mesmo ser associado à plebs. Faremos, ao longo deste capítulo, uma análise mais atenta dessas questões conceituais. 
alguns excertos como no De Clementia, a revolta pública (De Clem. III, XXIII, $3)^{68}$.

Essas expressões turba, populus, multitudo, humillis, ignobilis, uulgus e plebs, em um âmbito geral, significam arraia miúda, vulgar, multidão comum, grupo de pessoas em desordem, confusão. Queremos destacar, com estes termos, mais do que significados torpes e sim críticas que nos conduzem a uma maior compreensão das relações de poder destes setores da sociedade.

Como temos argumentado, o universo senequiano é um quebracabeça e nem sempre encontramos respostas com a lógica que pretendemos e esperamos. Por isso, começaremos a trilhar suas informações sobre a forma com que estrutura a sociedade.

\subsection{Estrutura Social}

Guarda no teu espírito essa imagem: a fortuna brinca com os homens, espalha ao acaso entre eles as honras, as riquezas e os favores.

Sêneca

\section{Epistulae Morales}

As narrativas de Sêneca apresentam a sociedade romana por multiplicidade de fatores que conduzem os indivíduos à promoção social, tais como: honra, riqueza, poder de influência, relação de patronagem, condição jurídica, entre outros. O resultado disto é a associação dos setores subalternos a diversas temáticas como: prazeres, preferência literária, morte, troca de favores, reações populares, ações individualizadas, contra, ou a favor, de seus

\footnotetext{
${ }^{68}$ Além desse sentido indicado acima, encontraremos significados de publicus como multidão que não tem nada a oferecer, senão loucura. Segundo a concepção de Sêneca, "por vão desejo de tornares conhecido o teu talento não deves misturar-te com o público a ponto de desejares fazer leituras ou participar em debates. Aconselhar-te-ia a fazê-lo se tivesses mercadoria adequada a esta gente; mas entre ela não há quem pudesse entender-te" (Non est ergo quod te gloria publicandi ingennii producat in medium, ut recitare istis velis aut disputare; quod facere te vellem, si haberes isti populo idoneam mercem. Nemo est, qui intellegere te possit) (Epist. Mor. 7, 9).
} 
superiores, aparecendo ainda como categorias jurídicas representadas por plebe, libertos e escravos.

Dentro deste quadro, o filósofo aponta para uma oposição, plebe versus liberto, expressa no seguinte excerto: "E, até agora, estou falando das canalizações da plebe: que não dizer quando me referir aos balneários dos libertos"? (Et adhuc plebeias fistulas loquor: quid, quum ad balnea libertinorum pervenero?) (Epist. Mor. 86, 7) $)^{69}$

Isso implica que o conjunto compreendido por plebe não agrupa escravos e libertos. São categorias distintas. De acordo com suas palavras: "A natureza me aconselha a ser útil a todos: se forem livres ou escravos, ingenui ou libertos, livres por direito ou por amizade, que diferença faz? Onde existir um homem, existirá a oportunidade de fazer um benefício" (Hominibus prodesse natura me iubet [et] serui liberine sint hi, ingenui an libertini, iustae libertatis an inter amicos datae, quid refert? Ubicumque homo est ibi beneficii locus est) (De Vita Beata XXIV, 3).

Pode-se concluir, pela passagem, que a hierarquia não teria motivos de existir, em relação à concepção filosófica, se estivesse centrada na prática do bem ${ }^{70}$. No entanto, sob o ponto de vista societário, as hierarquias -

${ }^{69}$ A separação entre plebe e liberto sob a perspectiva de Sêneca, não é compartilhada por autores como Tácito (e.g. Anais e Histórias) que trata os libertos como parte do grupo que pertencia à plebe. A historiografia contemporânea, de modo geral, utiliza esses documentos como fonte de informação histórica, referindo-se à composição da plebs como tendo libertos, escravos, responsáveis pelo desenvolvimento de diversas atividades como artesãos ricos e pobres, estivadores, médicos etc. Consultar: GUARINELLO, N. L.; JOLY, F. Ética e ambigüidade no principado romano. In: BENOIT, Héctor; FUNARI, Pedro Paulo A. Ética e política no mundo antigo. Campinas: Unicamp, 2001, pp. 133/152; YAVETZ, Z. Plebs and Princeps. Oxford: Oxford University Press, 1969; BRUNT, P. La plebe urbana. In FINLEY, M. I. Estudios sobre Historia Antigua. Madrid: Akal, 1983, pp. 87/117;VEYNE, P. Le pain et le cirque: sociologie historique d'um pluralisme politique. Paris: Seuil, 1976; ALFÖLDY, GÉZA. História Social de Roma. Lisboa: Presença, 1989.

${ }^{70}$ Como vimos no capítulo segundo, Sêneca defende o estudo da filosofia, vinculado ao pensamento estóico, como âncora de sustentação do indivíduo. A vida em sociedade deve ser conduzida pela filosofia moral, sendo assim, os homens conseguem evitar hierarquizações 
explicitadas pelos binômios da escravidão x liberdade e de ingenus $x$ liberto garantem aos agentes sociais status, diferenciação e promoção. Esta hierarquização elucida o cerne da questão: a plebe faz parte do grupo de indivíduos livres por nascimento, enquanto o liberto é o grupo livre por direito ou por amizade. O sujeito, ainda que tenha conquistado a liberdade, continua com a mácula da escravidão. Trata-se da relevância enquanto status social descender de um homem livre.

Uma outra distinção em Sêneca que acentua a presença dos setores subalternos é a contraposição com aristocratas. Estes se dividiam, de modo geral, em membros da corte, senadores e cavaleiros (normalmente, aparecem por suas funções, magistraturas civis ou militares, e nomes como Crasso, Burro, Catão, Julho César, etc.) ou a partir de críticas sobre a conduta de vida, como a necessidade do luxo, a culinária e coleções de peças exóticas, práticas corruptivas daqueles que utilizam a res publicae para ganhos e privilégios pessoais (Apocolocyntoses, De Vita Beata, De Ira, De Tranquilitate Anima Epistulae Morales, De Ira, De Clementia, Brevitate Vitae). Vejamos alguns exemplos para ilustrar a questão.

Sêneca se refere à elite da seguinte maneira: "O sábio tem consciência de que todos esses que desfilam togados e purpurados, robustos, corados, estão de saúde, e não os vê nada diferentes de doentes desbocados" (Scit sapiens omnis hos qui togati purpuratique incedunt, ualentes colorati,

sociais e ações viciosas como piedade, inveja, ódio, cólera, ressentimento, responsáveis pelos desequilíbrios sociais.

O filósofo propõe ao indivíduo o domínio dos sentimentos e os enfrentamentos das vicissitudes com tranqüilidade. Daí contingências como a perda de terras, desprestígio, morte de amigos e até mesmo a escravidão não abala o homem possuidor de virtude. Este continua, de acordo com o pensador, sendo livre (De Clementia, Epistulae Morales, Consolatio ad Polybium, Consolatio ad Marciam, Consolatio ad Helviam, De Prouidentia). Os únicos bens relevantes para Sêneca, como sugeriu Faversani, "seriam aqueles derivados do cultivo da razão, uma demonstração cabal disso seria que todos os homens teriam ascendentes tanto da mais elevada, quanto da mais baixa categoria social" (FAVERSANI, 2000, p. 101). 
male sanos esse, quos non aliter uidet quam aegros intemperantis) (De Constantia Sapientis XIII, 2). Os setores não aristocráticos são vistos, neste caso, pelo ofício. Vejamos: "Como ficam irados, se o barbeiro foi um pouco negligente, como se estivesse a aparar os cabelos de um verdadeiro homem" (Quomodo irascuntur, si tonsor paulo negligentior fuit, tamquam uirum tonderet) (Ad Paulinum de Brevitate Vita XII, 3)!"

Sêneca emprega termos como togado e purpurado para se referir aos membros da aristocracia. Ainda que o tom seja de crítica, compreendemos o universo a que se refere: o setor subalterno é mencionado por um sujeito cuja atividade é de barbeiro.

O filósofo tem uma concepção elitista. Como membro da aristocracia, mantém um profundo desprezo pelos setores populares, trata-os como inconstantes e irracionais. Isto não significa que não fizesse observações mordazes contra os membros aristocráticos, mas centra-se na figura de alguns notáveis e não ao grupo social em si, diferentemente dos setores subalternos.

Um exemplo de crítica são os desregramentos da cúria. Na sátira Apocolocyntoses, os senadores, simbolizados pelo senado celestial, são apresentados como homens que privilegiam políticas como a troca de favores. Disto resulta, por conseqüência, a irresponsabilidade com a República (OMENA, 2002; 2005). Ainda que fosse subornável, a instituição senatorial funciona em alguns casos. O deus Jano, com as habituais características que proporcionam honestidade, paz e abundância e o divo Augusto, que se envergonha do poder 
(Apoc. X, 2), representam uma certa funcionalidade; ambos não se iludem com as promessas de Hércules, "bateram o ferro" contra a deificação de Cláudio ${ }^{71}$.

Encontramos igualmente outras passagens em que o filósofo pontua as diferenças sociais: "Não deves espantar-te também ao veres o estilo decadente ser aplaudido não só pelas camadas mais sórdidas da sociedade, mas até mesmo pelos ditos superiores: o que distingue umas camadas das outras é a toga, e não o espírito crítico" (Mirari quidem non debes, corrupta excipi non tantum a corona sordidiore, sed ab hac quoque turba cultiore; togis enim inter se isti, non judiciis, distant) (Epist. Mor. 114, 12). Nesta passagem, a toga representa um elemento de diferenciação, isto é, os togados são aqueles que possuem magistraturas civis e militares, enquanto, os setores subalternos são referidos pelo termo: "camadas mais sórdidas". Ainda que Sêneca pontue o espírito crítico como um dado diferenciador entre setores aristocráticos e populares, a toga representa, mais uma vez, um elemento marcante na constituição das hierarquias sociais. Citemos um outro exemplo:

e te parecia indigno que a ele, que se preparava para atacar uma lei, a toga tivesse sido arrancada no fórum e que, tendo sido arrastado sem trégua pelas mãos de um bando sedicioso desde o rostro até o arco de Fábio, tivesse tolerado palavras desonrosas, e cuspes e todas as outras ofensas da multidão ensandecida (et tibi indignum uidebatur quod illi dissuasuro legem toga in foro esset erepta quodque a rostris usque ad arcum Fabianum per seditiosae factionis manus traditus uoces inprobas et sputa

\footnotetext{
${ }^{71}$ Sêneca afirma que a aprovação ou desaprovação das leis gira em torno dos interesses dos poderosos. A deificação de Drusila, irmã do imperador Calígula, por exemplo, é aprovada pelo senador Lívio Gemínio, "curator" da Via Ápia, por dinheiro, declara ter visto Drusila subir aos céus. $\mathrm{Na}$ Apocolocyntoses, in terris, fez referência a este episódio, ridicularizando o endeusamento (Apoc. I, 2). Na Consolatio ad Polybium, execra Caio César por tamanha insensatez. $O$ imperador quer que sua irmã seja chorada ou venerada, ao mesmo tempo em que Ihe ergue templos e moradas divinas (Consolatio ad Polybium XVII, 5). A apoteose deve ocorrer dentro dos limites da sapiência, em um homem moralmente perfeito. Reprova sua banalização, nestas condições, qualquer um tornar-se-ia um deus.

Temos, portanto, na crítica senequiana, duas idéias centrais: a banalização do rei: qualquer "louco" poderia governar Roma, assim como Cláudio que costuma vender pequenos direitos de cidade (Apoc. III, 3) e se distrair jogando dados (Apoc. XV, 1). O senado é, igualmente, dominado pelo desequilíbrio e troca de favores. Roma teria sido libertada da tirania de Cláudio, no entanto, ainda existem os mesmos Hércules que contribuem com a política de manus manum lauat (Apoc. IX, 6).
} 
et omnis alias insanae multitudinis contumelias pertulisset) (De Constantia Sapientis I, 3).

Sêneca descreve de maneira negativa os inimigos de Catão chamando-os de "bando sedicioso" e, ao mesmo tempo, faz referência a uma multitudo ensandecida que agride Catão - um homem de bem - com cuspes e palavras desonrosas. Ainda sobre Catão, Sêneca comenta em tom de crítica sobre a posição e a situação da plebe e dos notáveis em relação ao momento político, classificando-os por diferentes categorias, apresentando-os pelo binômio: plebe versus notáveis:

Se quiseres, num esforço de imaginação, representar no teu espírito a situação que se vivia na época, verás de um lado a plebe, a totalidade da massa, erguida, do outro lado as classes senatorial e eqüestre, tudo quanto de nobre e escolhido havia na cidade, e no meio, sozinhos, abandonados, Catão e a República! (Si animo complecti volueris illius imaginem temporis, videbis illinc plebem et omnem erectum ad res novas vulgum; hinc optimates, et equestrem ordinem, quicquid erat in civitate sancti et electi; duos in medio relictos, rempublicam et Catonem) (Epist. Mor. 104, 31)

Como podemos observar, encontramos no discurso senequiano pelo menos três diferenciações: uma primeira entre plebe, escravo e liberto, e uma segunda, entre os setores aristocráticos e os subalternos, apresentados como plebe, escravo e liberto e, por fim, distinções internas em relação aos grupos aristocráticos e aos três grupos subalternos.

As distinções são visíveis, até mesmo entre escravos que se destacam por alguns elementos como idade, ofício, espaço urbano e rural, proximidade com o senhor ou o liberto que se sobressaí por sua posição social ou econômica, chegando, em muitos casos, a ter mais poder de influência que um aristocrata.

Essas distinções aparecem, em Sêneca, no quadro de relações interpessoais entre os agentes sociais, fossem de condição igual ou não, o que produzia benefícios para ambos. Sêneca, embora pontue a posição 
inferiorizada do escravo, afirma que o senhor poderia receber benesses dele. Trata-se de um benefício doméstico (De Beneficiis III, I, 1). O filósofo argumenta da seguinte forma: relevante é o sentimento do benfeitor e não sua posição social (De Beneficiis III, XVIII, 2). A condição servil não diminui o valor do ato pelo fato de a alma ser autônoma, independente e livre em seus movimentos (De Beneficiis III, XX, 1). O escravo recebe em troca benefícios como o ganho da liberdade (De beneficiis III, XXIII, 3-4) e são tratados com respeito, benevolência, entre outros.

Como podemos perceber a realidade social senequiana forma-se por uma multiplicidade de fatores que conduzem os setores sociais a diferentes experiências e hierarquias sociais. Estas variações não representam uma fragmentação no pensamento senequiano, mas demonstram, muito claramente, uma compreensão específica de sua sociedade. Pela diversidade que propicia uma visão mais ampla do indivíduo na sociedade, mostra cada um dos aspectos particulares das relações de poder e, por fim, leva em consideração o modo como se organizam os agentes sociais.

\section{Plebe romana e suas relações}


A plebe é retratada em Sêneca pelo anonimato e, por vezes, adjetivada como sordida plebs, imperita multitudo e credulum uulgus. Termos, por excelência, pejorativos, que contém de forma explícita um valor moral. Esta projeção negativa pode aparecer, como temos apresentado, em expressões: turba, populus, multitudo, humillis, ignobilis, uulgus e plebs, cujo sentido é marcado pela falta de comedimento, insensatez, o gosto por literatura e bens vulgares e é, principalmente, vista como uma massa sediciosa, predisposta à violência e geradora de conflitos.

Essa projeção negativa é perceptível no momento em que Sêneca critica tanto os gramáticos quanto os retóricos, que se enveredam por questões vazias, sem fundamento. Na obra Ad Paulinum de Brevitate Vitae, condena os estudiosos por se aterem em proposições como:

Há alguma utilidade maior em saber que o monte Aventino, como assegurava aquele, situa-se para além do pomerium por uma dessas duas razões: ou porque a plebe tenha se afastado daí, ou porque, quando Remo tomava os auspícios, o vôo das aves não foi favorável (Hoc scire magis prodest quam Auentinum montem extra pomerium esse, ut ille affirmabat; propter alteram ex duabus causis, aut quod plebs eo secessisset aut quod Remo auspicante illo loco aues non addixissent) (Ad Paulinum de Brevitate Vitae XIII, 8).

Este excerto suscita duas questões interessantes: Sêneca trata a movimentação da plebe no espaço urbano como um assunto menor, irrelevante e deixando de evidenciar que este fato ocorreu por uma reação da plebe contra os patrícios, por não terem acesso ao consulado ${ }^{72}$.

\footnotetext{
72 Segundo Grimal (2001), a plebe retira-se do pomerium, para a sua colina, o Aventino, onde se ergueu o templo Ceres, que era por excelência a deusa dos plebeus e declarou querer fundar uma cidade separada de Roma. Os patrícios aceitaram então que fossem criados magistrados plebeus, encarregados de proteger a plebe contra os abusos de poder dos outros magistrados (p. 35).
} 
A plebe mesmo sendo de origem livre é considerada ainda um grupo

de segunda ordem. Sêneca demonstra, mais uma vez, seu desprezo no

momento em que afirma:

Não temos em consideração, de momento, a crença por alguns partilhados de que cada um de nós foi colocado sob a tutela particular de um deus, não de um deus de primeira ordem, é evidente, mas de um daqueles inferiores, a quem Ovídio chama "a plebe divina" (Sepone in praesentia, quae quibusdam placent: Unicuique nostrum paedagogum dari deum, non quidem ordinarium, sed hunc inferioris notae, ex eorum numero quos Ovidius ait de plebe deos) (Epist. Mor. 110, 1).

Na obra Consolatio ad Polybium, aconselha o liberto de Cláudio,

dizendo: "nenhuma ação plebéia, nenhuma ação humilde te convém" (Nihil te plebeium decet, nihil humile) (Consolatio ad Polybium IV, 2). Qual seria, então, esta ação? A capacidade de sempre assediar o vestíbulo do outro (Consolatio ad Polybium VI, 2) ${ }^{73}$.

${ }^{73}$ De acordo com Norbert Rouland (1979), a clientela em Sêneca é condenada "porque pertence justamente às obrigações sociais cheias de futilidade. É uma crítica ao afastamento puramente filosófico, sem esboço de análise sociológica ou econômica. Constata-se facilmente que são recomendações de Sêneca que seguem sua crítica" (p. 535). Discordamos deste pressuposto pelo fato de Sêneca propor uma filosofia associada à prática social e não um sistema que se fundamenta apenas no plano das idéias. Ele busca a partir da filosofia compreender o mundo que se apresenta com suas estruturas: social, política e econômica. No momento em que censura as relações clientelísticas há, e não divergimos neste ponto, uma condenação filosófica, mas, sobretudo, a crítica de comportamento de clientes e patronos de sua época. Sêneca não realizaria elucubrações sociais, sem ter como parâmetro, o seu mundo real. Citemos um exemplo: "o mínimo fundamento para te deixares persuadir que alguém é feliz pelo fato de viver rodeado de clientes; os clientes não buscam nele senão o mesmo que buscam num lago: beber até fartar e deixar a água suja! O vulgo julga-lo-á um homem sem valor, sem atividade!" (Itaque non est quod tibi isti persuadeant, eum esse felicem, qui a multis obsidetur: sic ad illum, quemadmodum ad lacum, concurritur, quem, qui exhauriunt, et turbant. - Nugatiorum et inertem vocant.) (Epist. Mor. 36, 2)

Sêneca, nesta passagem, faz referências às relações de fidelidade. De acordo com Rouland (1979), "a antiga nobreza, com seus preconceitos, não é mais representada, uma vez que teria sido enfraquecida pelos acontecimentos do último século na República: a fides primitiva, que fundara a antiga relação de clientela, desapareceu completamente na época do Império: enfim, o patronato privado das coletividades locais conheceu um grande avanço na mesma época, o que é justamente um signo do poder do imperador, porque em geral, os patrões autônomos são seus funcionários e representam o papel de substituto, economizandoIhe as despesas que teriam custado a aplicação de uma tutela administrativa direta de sua parte sobre as coletividades locais" (p. 504). Ainda segundo o autor, "as circunstâncias econômicas permitem aos grupos dirigentes renovar constantemente seus efetivos clientelísticos dentre a massa crescente de indivíduos desamparados, esquecidos pela Fortuna de Roma. Porém, simultaneamente, essas mesmas determinantes econômicas fazem da plebe um tipo de massa perigosa, cujas aspirações ao exercício dos seus direitos políticos devem ser juguladas. O cuidado em evitar qualquer guinada democrática das instituições é a preocupação 
A plebe está, assim, somente disposta a alcançar a riqueza e os favores obtidos com as relações de clientela ${ }^{74}$. Um exemplo disto é a não retribuição de saudação, segundo o filósofo, Lucílio não deve sentir-se ofendido com esta situação (De Constantia Sapientis XIII, 3). Vista como uma multitudo irracional e inconstante não se deve confiar em seus critérios (Epist. Mor. 99, 17)!

Essas críticas refletiam situações na sociedade romana em que a plebe busca riquezas e relações sociais clientelísticas que garantem a obtenção de benefícios. Reagem, igualmente, contra aristocratas e se mostram interessados nas relações em troca de benefícios. O ato de não retribuir uma saudação representa uma afronta, do ponto de vista, aristocrático. A saudação é uma regra social que estabelece relações entre um superior hierárquico com um inferior. O não cumprimento simboliza desrespeito e, mais do que isso, o plebeu afeta o mos maiorum do notável, quer dizer, ignora seu pertencimento à elite, sua identidade enquanto grupo.

constante dos membros dos grupos dirigentes republicanos. Os pontos mais delicados da engrenagem institucional, nesse sentido, são as assembléias populares (especialmente os comícios das tribos) e o tribunato da plebe. Portanto, é lógico que, exatamente nesse nível, seja mais notável a utilização política da clientela. A finalidade política essencial da clientela reside, portanto, segundo nosso entendimento, na luta pela manutenção das estruturas aristocráticas do poder" (1997, p. 384).

${ }^{74}$ Segundo Elizabeth Deniaux e Pauline Schmitt-Pantel (1987): "em Roma, a alternativa não era se tornar cliente de Cimon, mas cliente do Estado: o cidadão romano era ao mesmo tempo cliente de César e do Estado, mas quando a ajuda era intermediada por um único patrão, César, corria-se o risco dos clientes do Estado se tornarem clientes apenas de César" (p. 159). As autoras concluem a análise sobre patronagem afirmando que "uma vez que as bases econômicas da relação patrão-cliente são mobilizadas, se leva em conta a forma em que o patronato se exprime, percebe-se que a partilha dos benefícios não materiais e benéficos não é satisfatória e que a relação de patronato raramente se reduz apenas aos aspectos materiais. A autoridade e 0 poder político se reforçam graças à repetição de gestos que as crenças religiosas e os costumes sociais conferem um certo peso. A estrutura de comunicação entre o social e o político e a relação de patronato nos leva a refletir sobre as práticas sociais coletivas por meio das quais o poder se mantém, tanto na Grécia quanto em Roma, práticas que, através das eleições de assembléias e magistraturas, estruturam a vida na cidade e são talvez de uma dimensão política" (p. 160). 
Sêneca, em um diálogo imaginário com Lucílio, fez a seguinte alusão: "Na província onde estás, por muito pouco que estimes o teu valor, és uma personalidade. Todos procuram saber como vives, como jantas, como dormes, e por isso mesmo tens de dar mais atenção ao teu estilo de vida" (Tu nunc in provincia, licet contemnas ipse te, magnus es: quid agas, quemadmodum coenes, quemadmodum dormias, quaeritur, scitur. Eo tibi diligentius vivendum est) (Epist. Mor. 43, 3). É, então, uma afronta social um plebeu não cumprimentar ou não se interessar pelo estilo de vida de um aristocrata.

Como podemos observar, o reconhecimento social é relativo, não ocorre de forma igualitária em todas as regiões. Sêneca confirma a condição de cavaleiro romano de Lucílio e comenta que "muitos há, todavia, a quem as catorze filas permanecem inacessíveis, nem todos têm entrado no Senado, até os quartéis escolhem com minúcia aqueles que são admitidos a participar nos duros perigos da milícia" (at mehercules multis quatuordecim clausi sunt. Non omnes curia admittit: castra quoque, quos ad laborem et periculum recipiant, fastidiose legunt) (Epist. Mor. 44, 2). Lucílio, muito provavelmente, teria a mesma disposição e influência em Roma, dependeria da riqueza e da relação clientelística com seu amigo Sêneca. Isto, é claro, se estivesse em Roma nos anos de ascensão do filósofo, caso contrário, não teria o mesmo privilégio. Assim como a situação social da plebs variava de acordo com a sua localização.

Em alguns textos é claro que Sêneca se refere à plebs da cidade de Roma. Temos algumas indicações: a movimentação deste grupo do pomerium para o monte Aventino (Ad Paulinum de Brevitate Vitae XIII, 8), a reação da 
plebs contra Calígula pela falta de alimentos (Ad Paulinum de Brevitate Vitae XVIII, 5/6), a movimentação da multitudo em locais como o fórum e teatro (Consolatio ad Marciam XI, 2), a reclamação do filósofo por morar em cima de uma terma e ter que suportar todo o tipo de ruído, levando-se em consideração que Sêneca mora em Roma (Epist. Mor. 56, 1/2), a afirmação de que a massa é autodestrutiva e que, portanto, Nero deve agir com cautela e prudência (De Clementia III, IV, 1).

A hierarquia social, deste modo, tal como podemos abservá-la através de Sêneca, retrata muito claramente a situação da cidade de Roma, muito mais que o Império como um todo. A cidade de Roma é o centro do poder imperial e o discurso senequiano reflete, muito bem está situação política. Sêneca discute as bases do poder imperial e afirma que o soberano deve manter equilíbrio social na capital, pois esta "cidade terá deixado de dominar no mesmo momento em que tiver deixado de prestar obediência" (idemque huic urbi finis dominandi erit, qui parendi fuerit) (De Clem. III, II, 2).

Dentro desta perspectiva, faz-se necessário compreendermos como Sêneca constrói a relação entre princeps e plebs como uma relação entre dois agentes sociais dentro da cidade de Roma. Como veremos, a visão de Sêneca é determinada, em grande parte, pelo modo como concebe as relações de poder na capital do Império. 
2. 1. Princeps e plebs: uma relação de mútuo auxílio

Entre os elefantes, o chefe é o de maior estatura; entre os homens, a chefia competia, não ao mais forte, mas ao moralmente superior. O chefe era eleito pelas suas qualidades, e por isso os antigos povos viviam em perfeita felicidade, já que era impossível ao mais poderoso não ser simultaneamente $o$ melhor. Um homem que entende o seu dever como limite rigoroso pode exercer o seu poder sem perigo para os demais.

Sêneca

Epistulae Morales

A sociedade, aos olhos de Sêneca, distancia-se da razão pela falta de comedimento, que abarca todos os campos relacionais, envolvendo desde escravos até cidadãos livres (De Ira XXXV, 1). Em De Constantia Sapientis, Sêneca questiona, com o mesmo tom de crítica, se há alguma diferença entre magistrados e crianças. De acordo com o pensador, as crianças se apossam de insignificantes ossinhos, nozes e moedinhas de cobre, enquanto os magistrados se apoderam de moedas de ouro, de prata e de cidades ( $D e$ Constantia Sapientis XII, 2).

O filósofo da stoa não vê os homens de seu tempo, na sua totalidade, preocupados em solucionar os problemas da República, mas em promover sua destruição. Este descontrole político e social é reproduzido ciclicamente (Epist. Mor. 24, 26), assim como a excessividade, a desobediência e a corrupção presente em todos os setores sociais. Diante de uma sociedade corrompida, o filósofo tem a esperança de que surja um rei justo, com poderes extraordinários para ordenar esses homens dispostos à tirania. 
Esse soberano sapiente tem o direito a patria potestas que representa o direito de ser o árbitro de vida e morte de seus súditos. Está em suas mãos à sorte e a posição de cada um na estrutura social (De Clem. Pr. I, 2). Ainda que tenha um grande poder, o soberano submete-se à temperança. De acordo com suas palavras, Augusto teria sido designado o "Pai da Pátria para que soubesse que lhe foi conferido o pátrio poder graças a seu grande comedimento em consultar os filhos e colocar seus próprios interesses depois deles" (Patrem quidem Patriae appellauimus, ut sciret datam sibi potestatem patriam, quae est temperantissima liberis consulens suaque post illos reponens) (De Clem. III, XII, 2).

Temos aqui duas proposições complementares: uma primeira é a qualidade do soberano em distribuir as devidas benesses a cada súdito, por ter como função: a assistência comum e o bem público (De Clem. II, IV, 3); e a outra, equivale a privilegiar os interesses do populus ${ }^{75} \mathrm{e}$, posteriormente, olhar seus interesses pessoais.

O imperator, nesse sentido, deve prestar contas à plebe, sendo moderador e benfeitor ${ }^{76}$; assim estabelecerá uma relação centrada na admiração e receberá em troca, aprovação de suas ordens. Evitará, por conseqüência, situações como as rixas, presentes, segundo Sêneca, nestes homens hierarquicamente inferiores (De Clem. III, V e 4). De acordo com o

\footnotetext{
${ }^{75}$ Nesta argumentação utilizo o termo populus em sentido geral, o de povo romano. Como afirmamos anteriormente, em alguns casos, Sêneca refere-se a populus para indicar: império (De Clementia Pr. I, 5; III, II, 2), povos das províncias fronteiriças (De Clem. I, I, 3), povos de cidades em geral (De Clem. III, I, 4).

${ }^{76} \mathrm{O}$ princeps deve privilegiar também suas relações com os membros da elite. Um exemplo disso são as observações apresentadas na obra De Clementia, na qual Sêneca argumenta que se Nero fundasse suas ações na moderação teria, em contrapartida, aprovação de suas ordens pelos altos dirigentes e admiração (De Clem. Pr. I, 9; III, XI, 4; III, XVI, 1); caso contrário, somaria inimizades que não contribuiriam para o exercício de sua potestas (De Clem. III, VI, 5; III, VIII, 2). Um soberano que seguisse o exemplo de Augusto no período das proscrições, só conseguiria estabelecer um clima de inimizade e não impediria as cervizes do povo romano ( $D e$ Clem. III, VIII, 2).
} 
pensamento senequiano, mesmo os homens humildes, a quem tudo falta, devem ser agraciados com o nome de homens (De Clem. Pr. I, 3).

Mesmo que houvesse alguma punição por parte do princeps sapiens,

há, igualmente, a conformidade que corresponde à passividade consentida, à sujeição a ordem vigente ${ }^{77}$. De acordo com Sêneca,

o que é mais admirável do que ver o homem, cuja cólera não encontra nenhuma oposição, cujos veredictos, mesmo os mais pesados, são aprovados pelos que vão morrer, a quem ninguém interpelará ao contrário, a quem ninguém sequer suplicará (Quid enim est memorabilius quam eum, cuius irae nihil obstat, cuius grauiori sententiae ipsi, qui pereunt, adsentiuntur, quem nemo interpellaturus est, immo, si uehementius excanduit) (De Clem. III, III, 4).

Sabemos, pois, que o soberano, de acordo com a concepção senequiana, deve relacionar-se com o populus pelo fato de o poder ser pactuado, mesmo em se tratando de um sistema centralizador, "engana-se, pois, quem julga que é seguro ser rei quando nada é assegurado para o rei. A segurança deve ser pactuada através da segurança recíproca" (Errat enim, si quis existimat tutum esse ibi regem, ubi nihil a rege tutum sit; securitas securitate mutua paciscenda est) (De Clem. III, XVII, 5).

Sêneca percebe a fragilidade do poder, especialmente, em ações tirânicas. A crueldade aumenta o número de inimigos, pois ao suprimi-los "os pais e os filhos, os parentes e os amigos dos que foram mortos tomam o lugar de cada uma das vítimas" (parentes enim liberique eorum, qui interfecti sunt, et propinqui et amici in locum singulorum succedunt) (De Clem. III, VI, 7). Mesmo

\footnotetext{
77 Utilizamos o conceito das quatro categorias propostas por Georges Balandier (1976): conformidade, estratégia, manipulação e contestação. São práticas situadas, todas, no sistema social existente, quando o conceito de revolução diz respeito a práticas mais definidas com relação a um sistema social porvindouro (...) A conformidade corresponde à passividade mais ou menos consentida, a sujeição à ordem vigente. A estratégia nasce do fato de que certos agentes sociais tentam utilizar ao máximo, em seu proveito, as normas e as regras que governam os sistemas e as situações pelas quais eles se manifestam (...) A manipulação tem o mesmo objetivo - a máxima vantagem - mas só na aparência respeita as normas e as regras. $\mathrm{A}$ contestação provoca, em graus variáveis, uma revisão da ordem social; resulta das práticas que contribuem para esboçar uma contra-sociedade no seio da sociedade "oficial" (p. 53).
} 
um escravo, uma serpente ou uma flecha pode tirar a vida de um rei (De Clem. III, XIX, 1).

A manutenção de sua potestas deve ser negociada com a plebe. Sêneca, não sem razão, exorta a magnificência e a aproximação do imperator aos seus subordinados (De Clem. III, XI, 4). O filósofo aconselha Nero a cativar, sobretudo às massas (De Clem. III, XI, 4). Sabe que todos esperam a sua porção, desde os poderosos até os insignificantes ${ }^{78}$. Segundo sua opinião, "cada um sente e espera menores ou maiores bens de acordo com a porção de sua sorte, porém a clemência, todos esperam o mesmo quinhão" (cetera enim bona pro portione fortunae suae quisque sentit aut expectat maiora minoraque, ex clementia omnes idem sperant) (De Clem. Pr. I, 9).

Como podemos observar, o princeps, segundo Sêneca, fortalece-se pela plebe e não apenas, como é de consenso historiográfico, pelos setores aristocráticos. A permanência no poder, de modo geral, requer, por um lado, um conjunto de responsabilidades e obrigações do governante, que utiliza a paz e a prosperidade dos homens como ícones de propaganda. Em nome do bem público e de um estado de segurança é que se justifica a legalidade e, por conseqüência, a existência do poder. Por outro lado, este cenário político só é mantido pelo consentimento e reconhecimento dos governados.

\footnotetext{
${ }^{78}$ Como sugeriu Zvi Yavetz (1983), "as massas não são simplesmente um grupo passivo apenas desejando lutar pelo pão de cada dia; elas se mostram fiéis aos seus benfeitores e detestam os soberanos que os mantém à distância [...] o povo queria que o soberano vivesse próximo a ele, lamentando junto a má sorte e partilhando as alegrias. Para a plebe romana, a presença do imperador em Roma revestia-se de uma grande importância, aparentemente; as pessoas recebiam com amargura seus dons vindos de longe. No espírito popular, Capri se tornou sinônimo de endireitamento de bestas selvagens, em razão dos boatos que circulavam sobre a existência que ameaçava o imperador na solidão de sua ilha. Um imperador que não partilha os prazeres nem os lutos do povo, que se fecha em Capri, prefere não ser perturbado e coloca seus soldados para afastar a população local, se purifica da sorte que lhe trazia azar: 'Tibério ao Tibre!' pedia o povo sua morte" (pp. 155-6).
} 
Sabemos que o poder caracteriza-se também por ser um dispositivo produtor de efeitos, entre os quais os que se comparam às ilusões do teatro. $O$ governante torna-se um ator político para a conquista e a conservação do poder. Daí a relevância de sua imagem, das aparências que poderão corresponder aos desejos e expectativas de seus súditos ${ }^{79}$. Ainda que Sêneca não explicite, diretamente estes conceitos de potestas, expressa no tratado $D e$ Clementia, ensinamentos a Nero, sobre a melhor forma de governar. Tendo como ponto de partida, por exemplo, a utilização do mito da unidade que é expresso em conceitos como populus (De Clem. III, XX, 3).

Um reflexo disso é a utilização de estratégias de opinião pública, para adquirir vantagens e benesses do princeps e, em troca, manter-se no poder; são regras que direcionam e se manifestam na governabilidade. Ray Laurence (1994), em um estudo sobre a importância dos rumores na política romana do período republicano, discute sobre três formas de se obter informações políticas: observação pessoal, boato e rumor (p. 62). O que não devia ser diferente da política no Principado, época vivida por Sêneca. Segundo Laurence, o caminho para a transmissão não era linear: havia, primeiramente, uma interpretação pessoal e especulativa acerca da informação, que é anterior a comunicação, em segundo, a informação original depende das falhas de memória: apenas $40 \%$ da informação é realmente

${ }^{79}$ Utilizamos as definições de teatralização do poder propostas pelo antropólogo Balandier (1982). Este se baseia no que Nicolau Evreinov denomina por teatro da zombaria, quer dizer, "sua tese, expressa a partir de ilustrações extremamente variadas, monta um tribunal teatral para todas as manifestações da existência social, notadamente as do poder: os atores políticos devem 'pagar seu tributo cotidiano à teatralidade'" (EVREINOV Apud BALANDIER, 1982, p. 05). Como sugeriu Balandier, "o poder estabelecido unicamente sobre a força ou sobre a violência não controlada teria uma existência constantemente ameaçada; o poder exposto debaixo da iluminação exclusiva da razão teria pouca credibilidade (...) Ele só se conserva pela transposição, pela produção de imagens, pela manipulação de símbolos e sua organização em um quadro cerimonial" (p. 07). Consultar também: BURKE, P. O mundo como teatro. Estudos de Antropologia Histórica. Tradução de Vanda Maria Anastácio. Lisboa: DIFEL, 1992; GOFFMAN, Erving. A representação do eu na vida cotidiana. Petrópolis: Vozes, 1983; GEERTZ, Clifford. A interpretação das culturas. Rio de Janeiro: J. Zahar, 1978. 
reproduzida (p. 63). Nesta análise, as informações circulavam em rede entre patrono-cliente, assim como no próprio seio da elite. O autor interpreta o papel dos clientes como uma fonte de informação, particularmente, relevante na relação patrono-cliente da política romana. Esta relação, todavia, não garantia o resultado da votação, pois as redes de informações circulavam também entre os membros da elite (pp. 71-2). Daí Sêneca afirmar:

que nenhum bem é resultado de elementos discretos; contudo, a reputação dos homens de bem é resultado da opinião pública favorável. De fato, tal como a fama não resulta do apreço de um só homem nem a má fama do mau conceito de um só homem, assim também a reputação não significa ser tido em boa conta por um só homem; para que a reputação se forme é necessário o consenso de muitos homens de valor e respeitabilidade. Ela resulta, por conseguinte, do juízo formado por vários indivíduos, ou seja, por elementos discretos; logo, a reputação não é um bem (Dicitis, inquit, nullum bonum ex distantibus esse; claritas autem ista, bonorum virorum secunda opinio est. Nam quomodo fama non est unius sermo, nec infamia unius mala existimatio; sic nec claritas, uni bono placuisse. Consentire in hoc plures insignes et spectabiles viri debent, ut claritas sit. Haec autem ex judiciis plurium efficitur, id est, distantium: ergo non est bonum) (Epist. Mor. $102,8)^{80}$.

Sêneca considera a opinião pública uma poderosa arma para construir ou mesmo eliminar o poder de qualquer indivíduo, estivesse no espaço público ou privado. O príncipe, ocupando uma posição central, deve se preocupar com as opiniões maldosas, ou seja, deve manter sua boa reputação.

Daí a atenção do filósofo às exigências da multitudo, aqueles elementos discretos. De acordo com o pensador:

A opinião pública recolhe todos os vossos atos e palavras e, por esta razão, ninguém deve preocupar-se mais com a qualidade de sua reputação do que aqueles que hão de tê-la grande, qualquer que seja o merecimento que tenham tido (Uestra facta dictaque rumor excipit, et ideo nullis magis curandum est, qualem famam habeant, quam qui, qualemcumque meruerint, magnam habituri sunt) (De Clem. III, VI, 1).

Ele desenha o seguinte quadro: "não fazer qualquer coisa para a qual viesse a desejar o perdão da opinião pública, o juiz mais imparcial dos

\footnotetext{
${ }^{80}$ Há outras passagens que o filósofo comenta acerca dos rumores. Tais como: De Vita Beata I, 3; Consolatio ad Helviam V, 6; De Clementia III, XIII, 5, III, VI, 1; Epist. Mor. 81, 29.
} 
príncipes" (nec id in maioribus modo obseruasti, sed in minimis, ne quid faceres cui famam, liberrimam principum iudicem, uelles ignoscere) (Ad Marciam de Consolatione IV, 3). Em outro momento, "é indubitável que aquele que despreza os ataques que partem da turba se coloca mais alto do que ela" (IIlud non ueniet in dubium quin se exemerit turbae et altius) (De Ira III, XXV, 3). Esta relação contraditória com a opinião da turba, segundo Faversani (2000), é resultado da incapacidade de Sêneca em compreender como essa multitudo, composta por indivíduos pouco cultivados, age de forma conjunta ou não ( $p$. 143).

2.2. Plebe: relações de contra poderes.

Dentro deste quadro, devemos questionar, então, quais são as motivações que levam a multitudo a apoiar ou não o soberano. Sêneca, diferentemente do que julga Faversani, indica algumas ações que determinam a conduta coletiva da plebe. Vejamos:

1. Um primeiro fator fundamenta-se na falta de virtude, em especial, na cólera. Todos os vícios atingem o indivíduo, mas a cólera é a única que se apodera de toda a República (De Ira III, II, 2). No tratado De Clementia, escrito aproximadamente quinze anos depois do De Ira, Sêneca, continua a afirmar que a

cólera brutal e inexorável não fica bem a um rei, pois não o eleva muito acima daquele a quem se iguala ao irritar-se. Ao contrário, se concede a vida aos que estão em perigo e se confere dignidade aos que têm merecido perdê-la, faz aquilo que a ninguém mais é permitido fazer exceto ao que tem o poder sobre todas as coisas, pois até mesmo a um superior arrebata-se-lhe a vida, mas jamais é concedida a não ser a um inferior (Non decet regem saeua nec inexorabilis ira, non multum enim supra eum eminet, cui se irascendo exaequat; at si dat uitam, dat dignitatem periclitantibus et meritis amittere, facit, quod nulli nisi rerum potenti licet uita enim etiam superiori eripitur, numquam nisi inferiori datur) (De Clem. III, III, $6)$. 
Sêneca centra-se na perspectiva de que a cólera dos grandes desencadeie a ira particular, assim como as iras plebéias. Estas situações não são senão guerras sem armas e sem soldados (De Ira III, V, 6). De acordo com suas palavras, para "aos reis é mais certa a segurança que provém da mansidão, porque punição continuada reprime o ódio de poucas pessoas, mas estimula o de todos" (Patientia facit, regibus certior est ex mansuetudine securitas, quia frequens uindicta paucorum odium opprimit, omnium inritat) (De Clem. III, VI, 6).

O fator essencial são as reações coletivas. Sêneca ressalta a ação plebéia em contraposição às de caráter particular (De Ira III, V, 6). Leva-nos a supor que ocorriam reações públicas em Roma, como o caso do cavaleiro Triconte, por ter matado seu filho a açoites. Segundo a memória do filósofo, "o povo trespassou-o a golpes de estilete, no fórum. A autoridade de César Augusto mal conseguiu arrancá-lo das mãos agressoras, tanto de pais, quanto de filhos" (populus graphiis in foro confodit; uix illum Augusti Caesaris auctoritas infestis tam patrum quam filiorum manibus eripuit) (De Clem. III, XIII, 1).

O imperator é cercado por conspirações de cunho particular e por revoltas públicas que se inflamam por todo o Império, caso não sejam controladas. De fato, segundo Sêneca, as "ameaças ligeiras e individuais não perturbam cidades inteiras; mas aquilo que começa a espalhar seus furores amplamente e atacam a todos, é golpeado por todos os lados" (Leuis enim et priuata pernicies non totas urbes mouet; quod late furere coepit et omnes adpetit, undique configitur) (De Clem. III, XXIII, 3). 
O ponto crucial no discurso senequiano funda-se no elemento de instabilidade e desestruturação da ordem. Neste caso, o poder central poderia ser ameaçado por alguma ação coletiva, causando distúrbios no exercício de poder do imperator. Aos olhos de Sêneca, "os que estão em posição humilde têm maior desembaraço em forçar a mão, pleitear, correr para as rixas e deixar-se arrastar pela sua irritação" (Humili loco positis exercere manum, litigare, in rixam procurrere ac morem irae suae gerere liberius est) (De Clem. III, V e 4$)^{81}$

Essa massa retratada como sendo "as pessoas mais vis" (De Prouidentia V, 4) expressa, ao mesmo tempo, expectativas e opiniões e, com isso, influencia, mesmo indiretamente, o comando do princeps. Em algumas situações, de acordo com a argumentação senequiana, a ira do povo se abate de forma inesperada (Epist. Mor. 74,4$)^{82}$. Em Roma, a plebs, de modo geral, reage destruindo monumentos, estátuas e até mesmo prédios públicos e as ruas estreitas e edifícios altos dificultam a supressão dos motins. Nero, quando decidiu separar-se de Otávia - filha de Cláudio - para casar-se com Popéia,

${ }^{81}$ Aos olhos de Sêneca, as relações entre iguais, frente a alguma contrariedade, são mais amenas, "para um rei, até uma alteração de voz e falta de comedimento de palavras não são majestáticos" (regi uociferatio quoque uerborumque intemperantia non ex maiestate est) (De Clem. III, V, 4). Consultar Maria Antonietta Cervellera (1992) sobre as metáforas de poder em Sêneca. CERVELLERA, M. A. "Alcune notazioni su tematica e metafora del potere in Seneca". Rudiae, 4, 1992, pp. 101-115.

${ }^{82}$ Queremos ressaltar o seguinte aspecto: a reação contra a autoridade imperial poderia advir não apenas da plebe, em específico, mas igualmente de grupos de libertos associados ou não a seus patronos. Tendo, dessa forma, diferentes grupos de "notáveis" que questionam ou não o poder imperial. Como no fim da República, que alguns aristocratas tentam inibir as manifestações da plebs através de seu desarmamento. O populacho, de modo geral, se serve de pedras e bastões, sendo pena capital portar armas (BRUNT, 1981, pp. 96-7). Ainda segundo Brunt (1981), "a plebe urbana não era um corpo unido, e às vezes não sabemos que seção de dita plebe liderou esta ou aquela ação (...) Porém é preciso explicar algumas afirmações sobre as figuras "antipopulares" nos teatros através da hipótese de que eram patrocinadas por seus próprios clientes, aos que os patronos teriam concedido espaços" (pp. 110-11).

A plebe, na época de Nero, por exemplo, armada com paus e pedras, revolta-se com a decisão do Senado de condenar quatrocentos escravos pelo fato de um, ter assassinado o seu senhor, Pedânio Segundo. Coloca-se em vigor um velho costume transformado em lei sob Augusto, isto é, executam-se todos os escravos que vivem sob o mesmo teto do assassino (Tácito, Anais, XIV, 44). 
ocasionou insatisfação entre a população de Roma. A plebe derrubou as estátuas da pretendente e aquelas da esposa foram carregadas nos braços pela plebs ${ }^{83}$. Como afirmam Guarinello e Joly (2001),

talvez possamos ver, aí, em jogo, a própria legitimidade dinástica do imperador. Críticas aos meios adotados pelo imperador são perceptíveis, igualmente, nos grafites políticos que se espalharam em Roma, sem que possamos datá-los, acusando-o de matricida ou censurando a extensão que tomava o palácio de Nero, sua Casa de Ouro (p. 142) ${ }^{84}$.

Há, concomitantemente, manifestações que não possuem um caráter

violento. No período da República, por exemplo, o tribuno Galbinio organiza uma operação contra os piratas e os senadores se opõem; a plebe, então, invade o senado pelo fato de a pirataria provocar a diminuição de alimentos ${ }^{85}$.

${ }^{83}$ Em Pompéia, como propôs Funari (2001), os grafites expressam relações humorísticas que podem ser vistas como produtos de relações de poder e de contestação. Para Funari, os grafites estão divididos em dois grandes grupos: "aqueles que criticavam indivíduos e os grupos sociais em que se situam e aqueles, de caráter sexual, que se referem às relações de poder, em um contexto de oposição entre homens e homens, e entre homens e mulheres" ( $p$. 130). Fergus Millar (1998), analisando o voto popular, faz menção às Tabula Hebana: De acordo com suas palavras: "basta afirmar que a Tabula Hebana confirma o que já sabíamos de alguma forma através de Plínio, o jovem e Dio Cássio, que as reuniões de assembléias para votar continuaram até o período julio-claudiano e na verdade, por muito tempo depois. Quando Tácito escreveu que em 14 d.C as eleições eram pela primeira vez transferidas aos patres (o Senado), ele se referiu à prática de nomes irem antes do povo. Mas o princípio vital permaneceu com força, que o exercício público só poderia ser conferido por um voto popular" (p. 131). Haveria, por um lado, um sistema romano, referente ao século primeiro, baseado na autoridade, no Império constituído pela autoridade monárquica como cidade-estado. Por outro lado, a República teria alguns traços de democracia, um poder constitucional confirmado pelo voto do público. Muitos sistemas políticos, segundo Millar (1998), são complexos, uma mistura do novo e velho, autoridade e popular, monarquia e público. O autor argumenta, de forma interessante, que, em sentido formal, a legislação, a mudança de constituição e a ocupação do ofício foi requerido pela validação do voto pelo povo. Argumenta, igualmente, que Tácito concentrou sua análise nos votos efetivos do Senado como estratégia de obscurecer a nova República (cf. p. 134). Sêneca não nos fornece informações sobre voto popular, como foi apresentado na tabula Hebana analisada por Millar, apresenta-nos, entretanto, uma série de manifestações que demonstram situações conflitivas e participação popular.

${ }^{84}$ Como sugeriu Beth Severy (2000), "grandes grupos políticos, inclusive o senado, equites e a plebs eram convidados, enquanto grupos, para comemorar a potencial queda do chefe da casa imperial e expressar lealdade a Roma como devoção a esta grande família" (p. 126). Ainda, de acordo com a autora, "os louvores dos soldados, da plebs e dos eqüestres já citados concluem esta série de elogios de grupos bem definidos. É onde os autores apresentam uma ilustração de um estado ordeiro e pacífico a um público de governadores provinciais e soldados, e com isto estes elogios nos fornecem uma versão idealizada da estrutura hierárquica da sociedade romana. A lista termina com o elogio da força militar de Roma, precedida pelo elogio da plebe romana(155-58), um parágrafo elogiando os equites (151-54), contudo, significativamente, a lista começa com louvores a cada membro da casa imperial" (pp. 328-29).

${ }^{85}$ Consultar autores que discutem a movimentação da plebe no período republicano, a saber: LOPOSZKO, Tadeusz. Propagande politique de Cicéron em 63 av. J. -C. In: DOI, M.; YUGE, T. Forms of control and subordination in Antiquity. Leiden:E. J. Brill, 1988. p. 377-409; 
Sabemos que a miséria e a indigência provocam manifestações populares, principalmente em um mundo de políticos desinteressados em solucionar problemas como a escassez de alimentos.

O período de Augusto também é assolado pela falta de alimentos que provoca veementes discussões nas ruas. Embora não tivesse ocorrido quebra-quebra, a plebe ameaça incendiar o prédio do Senado, caso não aprovasse Augusto como cônsul - o povo atribui a situação de fome e de peste ao fato de o Augusto não ter recebido a nomeação do Senado.

No Principado de Tibério, a crise de abastecimento e carestia de cereais provoca protestos por parte da plebe (Anais, VI, XIII). Desgastado com a sedição do povo, Tibério, culpa os magistrados e cônsules por não terem utilizado a força pública e, dessa forma, coibir a multidão (Anais, VI, XIII).

2. Sêneca, mesmo posteriormente, vê o problema da escassez de alimentos como um dos motores geradores de ações coletivas. Para o filósofo, os indivíduos em constantes necessidades não aceitam e nem compreendem a falta de alimentos. Como retrata para o prefeito da anona:

Tu lidas com o ventre dos homens! O povo esfaimado não dá ouvidos à razão, não se aplaca pela moderação, nem se dobra a nenhum argumento. Muito recentemente, naqueles poucos dias após a morte de Caio César, diz-se que ele se indgnou muitíssimo (se há ainda algum sentimento nos infernos), porque sabia que o povo romano lhe sobrevivia e ainda lhes restavam provisões para sete ou oito dias! $\mathrm{E}$, enquanto ele construía pontes de navios e divertia-se com as forças do Império, estava às nossas portas o pior dos males, até mesmo para os sitiados: a falta de alimentos. Seu infeliz desejo de imitar um rei arrogante, estrangeiro e louco, quase custou à cidade a miséria e a fome, e o que se segue à fome, a ruína de tudo. (Cum uentre tibi humano negotium est; nec rationem patitur nec aequitate mitigatur nec ulla prece flectitur populus esuriens. Modo modo intra paucos illos dies quibus C. Caesaer periit (si quis inferis sensus est) hoc grauissime ferens quod decedebat populo Romano superstite, septem aut octo certe dierum cibaria superesse! Dum ille pontes nauibus iungit et uiribus imperi ludit, aderat ultimum malorum obsessis quoque, alimentorum egestas; exitio paene ac fame constitit et, quae famem sequitur, rerum

DRUMMOND, A. Rome in the fifth century II: the citizen Commnity. The Cambridge Ancient History, Vol. VII, part. 2, Cambridge University Press, 1989. pp. 172-242. 
omnium ruina furiosi et externi et infeliciter superbi regis imitatio) ( $A d$ Paulinum de Brevitate Vitae XVIII, 5) ${ }^{86}$.

Podemos constatar nesse grupo heterogêneo da plebe, como sugerem Guarinello e Joly (2001), "éticas políticas sem formulação sistemática, atuando pelos instrumentos do rumor, da manifestação e da agitação aberta" (p. 144). Trata-se de manifestações singulares que não coincidem, necessariamente, com aquelas atribuídas à elite (Ibidem). São éticas voltadas às discussões nas ruas, com incursões violentas ou não, em locais essencialmente públicos, onde se realizam, por exemplo, jogos gladiatoriais, representações cênicas, cassadas e naumaquias.

\subsection{Espaço público: formação de identidade}

Essa associação da plebs com a violência reflete uma importante realidade: o espaço público das ruas, teatros, tabernas onde se movimentam diferentes pessoas é formado por locais onde predominam contradições, surpresas, conflitos, perigo eminente de roubo, violência física, sendo ambientes fundamentalmente instáveis ${ }^{87}$. Sêneca apresenta, entretanto, outros espaços representantes do mos maiorum aristocrático. Um exemplo encontra-

\footnotetext{
${ }^{86}$ Além da diminuição de alimentos que gera descontrole, temos, igualmente, reivindicações pela crise de habitações - provocadas pelos incêndios, pelas inundações do Tibre, pela cobrança rigorosa de impostos e pelo aumento dos preços dos alugueis, causando um clima de insatisfação popular. Sêneca, em relação aos incêndios, fez referência à colônia de Lião, devastada pelo fogo. De acordo com suas palavras, "uma única noite deitou por terra inúmeros edifícios monumentais, tais que cada um só por si faria o orgulho de muitas cidades; em plena paz, sofreu mais destruições do que teria sofrido no meio da guerra" (Tot pulcherrima opera, quae singula illustrare urbes singulas possent, uma nox stravit: et in tanta pace, quantum ne bello quidem timeri potest, accidit) (Epist. Mor. 91, 2).

${ }^{87}$ Utilizamos como fundamentação teórica, a proposta de Roberto DaMatta (2004) sobre como a sociedade brasileira vive nos espaços público e privado. Segundo o autor, há um diferencial entre a rua e a casa, citemos in extenso: "A casa provê uma leitura especial do mundo brasileiro. É certo que toda sociedade moderna tem sua casa e rua. Mas, entre nós, a casa ordena o universo com normas e práticas diferenciadas do domínio da rua. Num certo sentido a casa, onde somos reis e donos, nos protege da rua, onde não somos coisa alguma. Se, portanto, nas nações modernas, casa e rua (público e privado) são governadas pelas mesmas normas, no Brasil há uma sensível diferença entre as leis que governam a rua, as instituições do Estado e o espaço público em geral, e os hábitos da casa que estão nos nossos corações" (p. 17).
} 
se em De Vita Beata, em que o pensador elabora um contraste entre locais representantes da virtude e do vício. Citemos in extenso:

A virtude é elevada, excelta, régia, invicta e infatigável; o prazer é baixo e servil, débil e fugaz, sua sede e morada são os prostíbulos e tabernas. A virtude, a encontrará no templo, no foro, na cúria, ereta ante o muro aprumado, coberto de pó, queimada de sol, com mãos calosas; o prazer sempre furtivo ou na escuridão reside junto às termas ou locais sob a mira da justiça, fraco, enervado, encharcado de vinho e perfume, pálido e maquilado, embalsamado como cadáver (Altum quiddam est uirtus, excelsum et regale, inuictum infatigabile: uoluptas humile seruile, imbecillum caducum, cuius statio ac domicilium fornices et popinae sunt. Virtutem in templo conuenies, in foro, in curia, pro muris stantem, puluerulentam, coloratam, callosas habentem manus, uoluptatem latitantem saepius ac tenebras captantem circa balinea ac sudatoria ac loca aedilem metuentia, mollem, eneruem, mero atque unguento madentem, pallidam aut fucatam et medicamentis pollinctam) (De Vita Beata VII, 3).

O que parece notável na leitura senequiana é que o universo espacial da elite marca-se pela estabilidade, relações previsíveis e conhecidas, enquanto os espaços dos setores subalternos representam, por sua vez, violência e contravenção. Quer dizer, os espaços comandados pelos membros da elite são vistos como lugares de atividades lícitas, meritórias, exclusivas da virtuosidade, ao passo que prostíbulos e tabernas são locais freqüentados pelas pessoas mais vis (De Prouidentia $\mathrm{V}, 4$ ) e, portanto, simbolizam ilegalidade, fraqueza e prazer.

Um exemplo marcante de violência, segundo a leitura de Sêneca, são os jogos que direcionam o público a atos violentos. Toma como ponto de partida o combate propriamente dito, considerando-o um homicídio à luz do dia (Epist. Mor. 7, 3) ${ }^{88}$. Aos olhos do pensador,

\footnotetext{
${ }^{88}$ Os espetáculos são classificados da seguinte forma: munera onde se realizam os combates gladiatoriais; Iudi scaenici, essencialmente, no teatro em que se apresentam peças trágicas e cômicas e onde acontecem os concursos e, por fim, ludi circenses incluem corridas de cavalos, exibições dos atletas, combates de animais e naumaquias. Consultar Garraffoni sobre a arquitetura dos ambientes dos jogos gladiatoriais. GARRAFFONI, R. S. Anfiteatros de pedras: tecnologias e monumentalidade nas cidades romanas. In: Gladiadores na Roma Antiga: dos combates às paixões cotidianas. São Paulo: Annablume/Fapesp, 2005, pp. 114127; e a respeito do teatro: DUPONT, Florence. L'acteur-roi. Le théatre dans la Rome antique. Paris: Les Belles Lettres, 2003.
} 
o homem - que para o homem devia ser coisa sagrada - é exposto à morte apenas para servir de divertimento; já era sacrilégio treinar homens para ferirem e serem feridos, agora os apresentamos nus e desarmados, bastanos a simples morte como espetáculo (Homo, sacra res homini, jam per lusum et jocum occiditur; et, quem erudiri ad inferenda accipiendaque vulnera nefas erat, is jam nudus inermisque producitur; satisque spectaculi ex homine, mors est) (Epist. Mor. 95, 33).

Essa relação de violência nos espetáculos, em Sêneca, segundo a perspectiva de Garraffoni, existe:

nos argumentos dos autores que afirmam que Sêneca é contrário aos combates, poucos fazem a distinção entre uma luta de gladiadores e as execuções de criminosos. O que Sêneca descreve no trecho em questão não se trata de um combate, mas o cumprimento de uma das penas capitais presentes na legislação romana (p. 44).

O filósofo, neste exemplo (Epist. Mor. 7, 5) referido pela autora, realmente comenta sobre a aplicação de uma pena capital. Temos, por um lado, a questão do cumprimento da pena: não deixa de ocorrer em um local que se realiza o munera. Por outro lado, o filósofo não recrimina por si só, a participação ou a freqüência do público nos espetáculos. Tanto é evidente, que o próprio Sêneca confirma: "fui casualmente assistir ao espetáculo ao meio dia, à espera de encontrar algo ligeiro, de divertido, algo que descansasse os olhares dos homens da vista do sangue humano" (Casu in meridianum spectaculum incidi, lusus exspectans, et sales, et aliquid laxamenti, quo hominum oculi ab humano cruore acquiescant) (Epist. Mor. 7, 3).

Trata-se de uma condenação que é resultado da crítica a qualquer tipo de excesso, sendo esta uma posição tipicamente estóica. Sêneca reprova qualquer ação, seja pelo viés do prazer ou pela punição que se torna insuportável para a condição humana. Mesmo em se tratando do imperator, cumprindo seu dever, não poderia punir com severidade ou com requintes de crueldade (De Clementia II, I, 1 e 2). O hábito em si de freqüentar os 
espetáculos não é reprovado por Sêneca e sim o que ultrapassa seus critérios de normalidade.

A referência aos espetáculos como símbolo de massacre é resultado também de sua preocupação política. Aos olhos de Sêneca, os jogos geram violência entre a multitudo que, a princípio, é discordante, sediciosa e descontrolada (De Clem. Pr. I, 1; III, IV, 1). Temos, então, duas situações: uma primeira é a reprovação da participação da plebs nos espetáculos, e a outra é percepção de que o soberano deveria cativar, sobretudo, as massas (De Clem. III, XI, 4). Sêneca critica a existência dos espetáculos e, ao mesmo tempo, percebe a influência das massas sobre o princeps que lhes assegura os benefícios.

O princeps deve voltar-se diretamente às reivindicações da plebe por três motivos: primeiro, é vista como uma massa inconstante e, por isso, disposta a qualquer tipo de ação, violenta ou não; segundo, como tutor da ordem pública e como provedor tem que evitar qualquer desordem social ou política; e em terceiro, sendo Roma considerada o centro do poder Imperial, o soberano deve manter o equilíbrio social (De Clem. III, II, 2).

O espaço público é o cenário central dessa relação paternalística do princeps com a plebs. Por isso, o circo e o anfiteatro simbolizam espaços em que se demonstram desejos e protestos de toda ordem. Como sugere o antropólogo Balandier (1989), o teatro é "onde se apresenta à sociedade 'oficial' e, inversamente em que se manifesta o protesto popular" (p. 12). Ainda que esteja pensando o espaço teatral em outro período histórico (em específico à da Bastilha), podemos traçar um paralelo com a sociedade romana no seguinte aspecto: os espetáculos oficiais desempenham funções político- 
sociais. São festas promovidas tanto pelo imperator quanto pelos magistrados, que as consideram instrumentos de controle sobre as massas urbanas ${ }^{89}$. A platéia pode, no entanto, tanto apoiar as autoridades como fazer reivindicações de diversas ordens aos promotores presentes.

Temos dois conceitos implícitos: por um lado, a manipulação, que tem por objetivo a máxima vantagem; mas só na aparência respeita normas e regras e, por outro lado, a contestação, em graus variáveis, que exige uma revisão da ordem social. Isto implica no compartilhamento da plebe com as autoridades, desde que fosse atendida sua reivindicação, caso contrário, reagiria contra o soberano ou mesmo contra os promotores. A ação da plebe não tem por pretensão a transformação do sistema, embora à reação, muitas vezes violenta, seja inevitável a partir do momento que seus "benefícios" não fossem entregues. Por isso, Sêneca recomenda a um homem precavido, retirar-se do teatro, quando se inicia a distribuição de presentes. Sabe o quanto terá que ceder em troca de um pequeno favor (Epist. Mor. 74, 7).

Essa "distribuição de presentes", no caso dos jogos gladiatoriais, presididos na cidade de Roma, somente pelo imperator, ocorre pelo fato de 0 homem ser dependente, entre outras coisas, da quantidade e qualidade dos

\footnotetext{
${ }^{89}$ Interpretamos a festa como um fenômeno social e não simplesmente por particularidades de cunho individual; a compreendemos por meio de uma ação coletiva que implica, necessariamente, na ênfase dos sentimentos e emoções experimentadas pelos participantes. Como sugere Guarinello (2001), a festa é, por fim, uma produção social que produz uma identidade entre os participantes e o compartilhamento do símbolo que é comemorado e "que, portanto, se inscreve na memória coletiva como um afeto coletivo". Representa a produção de memória e da identidade no tempo e no espaço sociais e é, portanto, um produto histórico, uma instituição passível de História e de evolução ao longo do tempo (p. 971).

Um outro exemplo de ato festivo é o funeral de Cláudio relatado na sátira menipéia Apocolocyntoses como um ato festivo. Marca não somente a transição de governante, mas discursa sobre uma era de renovação, uma era de ouro. Percebe-se, segundo Sêneca, uma contagiosa emoção, todo o populus está em festa, não faltam flautistas e corneteiros (Apoc. XII, 1) e todos, sem exceção, sentem-se livres (Apoc. XII, 2 e 3); apenas bajuladores como Agatão e alguns rábulas "se queixavam de todo o coração" (Apoc. XII, 2).

Nero é o filho de Febo, o filho de ouro. Nada mais razoável que a realização de um funeral grandioso com a participação de todo o populus romanus em plena alegria. A morte de Cláudio poria fim às injustiças e impunidades.
} 
espetáculos oferecidos à cidade. No caso da participação dos notáveis, temos duas questões: a primeira gira em torno do apoio que podem obter deste setor, principalmente, em disputas pelo poder e, em segundo, o prazer pelos jogos: muitos deles participam, não somente como expectadores, mas lutam na arena, embora tenham sido amplamente reprovados por seus contemporâneos aristocráticos.

Devemos ressaltar um importante fator em relação aos espetáculos: são muito mais do que um mecanismo reprodutor de uma hegemonia de grupos dominantes. Expressam uma relação de mútuo auxílio entre a massa e o princeps: este distribui privilégios e benefícios e a massa, por outro lado, reconhece-o e legitima-o no poder. Esta relação torna-se, como afirmamos anteriormente, fonte de estabilidade e preservação do princeps no poder ${ }^{90}$. Além do mais, como acentua Regina Maria da Cunha Bustamante (2005), "os espetáculos constituíram-se em um elemento essencial do modo de vida romano, uma peça importante da sua identidade" (p. 222) ${ }^{91}$.

\footnotetext{
${ }^{90}$ Como sugere Florence Dupont (2003), "a ida aos espetáculos era um sinal de submissão direta ao imperador, os senadores rendiam por dever afetando o desprezo pelos prazeres lúdicos populares: desprezo suspeito quando se sabe que eles assistiam em casa a espetáculos similares e até mesmo participavam como atores. O que eles recusam no jogo é o seu significado político. Ser espectador é se reconhecer sujeito do imperador, é por isso que recusar freqüentar o circo e o teatro é um sinal de fidelidade às grandes famílias da aristocracia republicana dos plebeus. Pois o império dos magistrados que era tradicionalmente atribuído ao presidente dos jogos, daquele momento em diante seria monopolizado pelo imperador ou por aqueles que o representavam e aos quais ele delega seu poder" (p. 418).

${ }_{91}$ Monique Clavel-Lévèque (1986), em um artigo - L'espace des jeux dans le monde romain afirmou que os jogos: "constituem um aparelho ideológico complexo destinado, essencialmente, a assegurar e reproduzir a hegemonia dos grupos dominantes" (p. 2410).

Além deste caráter inegável, acentuado por Clavel-Lévèque, os espetáculos possuem "traços do seu caráter religioso original, por exemplo, no referido rigor cerimonial, que uma omissão, uma negligência obrigavam a recomeçar tudo; nos sacrifícios que precediam, acompanhavam e seguiam os jogos; na pompa circenses, que era uma espécie de procissão religiosa; nas honras concedidas aos vencedores, que estavam relacionadas a sua condição sobre-humana por alcançar a vitória (...) Assim, as ocasiões em que se celebravam os jogos envolviam algum caráter sagrado, mesmo que, com o decorrer do tempo, as multidões de espectadores na época imperial não estivessem tão imbuídas deste sentimento religioso. Seja como for, a Igreja Cristã, apesar de sua campanha, não conseguiu que festejos fossem abolidos por autoridades locais sob o pretexto de sua associação com os 'ritos profanos', que
} 
Assim como a felicidade para os efeminados, segundo Sêneca, é uma encenação (Epist. Mor. 80, 9), o poder político utiliza-se do mesmo recurso como parte de uma ação protocolar, na qual se possibilita à massa a participação nos espetáculos entregando-lhe a decisão sobre a vida ou morte do gladiador. Este poderia baixar sua arma e apelar para a misericórdia do populus (Epist. Mor. 37, 2).

O que parece é que a escolha sobre o tipo de espetáculo apresentado depende das preferências do público, o que indica uma expressão de poder, pelo menos do ponto de vista simbólico, pois as autoridades têm o cuidado de optar por espetáculos que agradam o público. Nas Epistulae Morales, Sêneca trata com pesar sobre a freqüência dos espetáculos em relação às boas artes. De acordo com suas palavras: "quanto maior a ocorrência fútil e volúvel ao espetáculo, tanto maior o deserto em torno das boas artes; que fraqueza a desses atletas de quem admiramos as espáduas musculosas" (quantus ad spectaculum non fidele et lusorium fiat concursus, quanta sit circa artes bonas solitudo; quam imbecilli animo sint, quorum lacertos humerosque miramur) (Epist. Mor. 80, 2).

O excerto acima nos mostra uma questão relevante: a crítica senequiana refere-se à prática destes espetáculos que, segundo o autor, reflete a fraqueza mental dos atletas e, indiretamente, a debilidade dos dirigentes que optam pela realização de atividades populares, deixando de lado as manifestações culturais ${ }^{92}$.

os tinham originalmente acompanhado e que agora eram proibidos" (BUSTAMENTE, 2005, p. 228).

${ }^{92}$ Como propôs Dupont (2003), "no teatro, o povo romano conquistou um poder de expressão que não tivera antes. O teatro é o único lugar em que o povo se reunia em sua totalidade, todas as classes se confundiam. Ele tinha o poder do número. É por isso que muito cedo se começou a separar os lugares, a vir de toga e organizar um ambiente estritamente hierarquizado para o público. A mutação é cumprida, Roma passa de uma política do 
Essa determinação espacial é uma forma de pontuar a existência de identidades de grupos nos espaços públicos da sociedade romana. A conseqüência disto é que a sociedade não pode ser explicada apenas pelas relações pessoais, pois estas se enquadram em códigos e símbolos sociais, que extrapolam as normas de pessoalidade. Se assim não fosse, qual o motivo que o filósofo teria em direcionar o discurso a ambientes representantes da virtude e do vício (De Vita Beata VII, 3), locais em que se discernem a presença de grupos específicos, como os pertencentes à elite e aos setores subalternos?

Um exemplo disso é a referência às termas. Sêneca, em um dos diálogos imaginários com seu amigo Lucílio, critica o excesso de luxo dos balneários e identifica dois grupos específicos: plebe e libertos (Epist. Mor. 86, 8). Além de suas críticas mordazes à inutilidade do luxo, Sêneca constrói, em sua narrativa, grupos distintos e heterogêneos que se reconhecem e se identificam em determinados locais públicos (e.g. assim como foi relatado no caso do balneário, identificado por terma de plebeus e libertos (Epist. Mor. 86, 8)), não importando quão diferentes sejam seus membros em termos de situação econômica, étnica, status, posição social, econômica ou o tipo de ofício, entre outros aspectos. Sêneca representa cada um dos três grupos, diversificados entre si, como pertencentes à mesma e grande família. Plebeus, libertos e aristocratas se reconhecem cada qual com seus símbolos expressos nas esferas pública e privada.

Isso não significa que a identidade seja fixa, essencial ou permanente. Sabemos que identidade era (e ainda é em nossa sociedade mítico que se apóia no aparato da púrpura, de outro, os espetáculos que são os únicos lugares de encontro do povo romano como coletividade reunificada" (pp. 30-31). 
contemporânea) móvel, formada e transformada continuamente em relação às formas pelas quais os agentes eram representados ou interpelados nos sistemas culturais. A identidade é definida historicamente e um sujeito pode assumir identidades distintas em diferentes momentos, i.e., elas não são unificadas ao redor de um "eu" coerente. Uma identidade unificada, completa, segura e coerente é fantasiosa.

A própria relação de poder do princeps com a plebs gera uma identidade coletiva. Como sustentam Guarinello e Joly (2001), "a própria presença física do imperador garantia à plebe que esta se encontrava no centro do Império e que era parte de sua estrutura de dominação" (p. 143). Estabelece-se, nesse sentido, uma relação paternalística que reserva a possibilidade de, a qualquer momento, mobilizar as massas em favor do governante. A plebs é fiel ao soberano que demonstre amizade e proximidade. Qualquer substituto mantenedor da memória deste será amado e respeitado.

Concluiremos a discussão, ressaltando dois elementos: a construção senequiana da potestas imperial perpassa à concessão de benefícios, mesmo sendo um sistema centralizador, o imperator deve manter relações "amigáveis" com todos os agentes sociais, mesmo aqueles considerados pelo filósofo, subalternos. Esta projeção política segue um caminho especifico: estabilidade e, por conseguinte, permanência do princeps no poder. Isto significa que o filósofo percebe, em uma primeira instância, a fragilidade da potestas que pode ser atingida por reações particulares e públicas. Estas, em segunda instância, demonstram a existência no sistema político romano: tanto condutas individuais contra ou a favor do soberano que se baseiam nas relações de pessoalidade, assim como ações coletivas, geradoras de comportamentos que 
se expressam publicamente no espaço social. Cria-se assim, identidade de grupo e propicia como é o caso da plebs, espaço de resistência, de apoio e de estratégias de afirmação social. 


\title{
3. Escravos: entre a passividade e a reação
}

\author{
"São escravos". Não, são homens."'São \\ escravos". Não, são camaradas. "São \\ escravos". Não, são amigos mais humildes. \\ "São escravos". Não, são companheiros de \\ servidão, se pensares que todos estamos \\ sujeitos aos mesmos golpes da fortuna.
}

Sêneca

Epistulae Morales

Neste subitem, propomos uma reflexão sobre a concepção de

Sêneca a respeito da escravidão e das relações de poder entre senhores e escravos, mesmo depois de conquistarem sua liberdade, na esfera social. Para tanto, dividimos o texto da seguinte forma: desenvolvemos uma análise sobre a escravidão sob um viés moral, discutindo as relações entre escravos e senhores, para verificarmos o processo de constituição das negociações e dos conflitos de articulação de poder em ambientes freqüentados pelos escravos. Trataremos primeiramente do conceito de escravidão senequiana.

O significado de escravo descrito no dicionário refere-se à pessoa mantida sob laços de servidão, considerada propriedade de outro (SARAIVA, 1993) e, como tal, incluída no conjunto classificado por terras, bens e dinheiro. O proprietário tem por direito o uso exclusivo de possuir, usufruir e dispor de sua propriedade. Assim como o gado, o escravo pode ser vendido, comprado, alugado, trocado, dado como presente ou herdado ${ }^{93}$.

\footnotetext{
${ }^{93}$ Segundo Jean Gaudemet (1992), enquanto "valor patrimonial, o escravo se torna objeto de transações: pode ser dado, vendido, herdado etc. Infelizmente, dispomos de poucas transações de venda de escravos. Os únicos documentos, em número suficiente, permitem conhecer os preços praticados, suas variações de acordo com a época e a qualidade dos escravos. Mas os juristas clássicos freqüentemente discutem as modalidades. Uma das áreas em que aparece mais claramente a oposição entre o rigor do direito e a prática social é sem dúvida o das uniões servis, serviles nuptiae, como qualifica Plauto, que, marcando o ilogismo jurídico desses casamentos, os declara solenemente celebrados" (p. 257). Sêneca, curiosamente, não faz referências à união matrimonial e nem mesmo ao casamento de escravos; o que não significa que não havia matrimônio, o filosófo deveria apenas desconsiderar a questão. Nas Epistulae Morales, faz alusão apenas a sua experiência pessoal: comenta sobre suas duas esposas. A primeira, de forma indireta: relata que ficou com sua
} 
A lei romana preocupa-se com o escravo para garantir sua submissão ao senhor. Teoricamente, o escravo não era uma pessoa. Era o instrumento de poder do dono que o utilizava, de acordo com seus interesses, pois, aos olhos do senhor, o escravo não tem vontade própria. Um exemplo disto é a escolha do ofício. O senhor determina a atividade desenvolvida pelo escravo e, dessa forma, define, igualmente, a categoria do escravo pelo exercício do ofício (e.g. aptidões artísticas e literárias). Sabe-se que um nobre romano, Calvísio Sabino, cerca-se de escravos que aprendem a recitar de memória Homero, Hesíodo e poetas líricos. De acordo com as palavras de Sêneca, Calvísio "comprou a alto custo uma série de escravos, um que sabia Homero de cor, outro, Hesíodo, e mais nove a quem encarregou de decorar os poetas líricos!" (magna summa emit servos, unum qui Homerum teneret, alterum qui Hesiodum; novem praeterea lyricis singulos assignavit) (Epist. Mor. $27,6)$.

Além do trabalho compulsório, o senhor tem o direito de vida e morte sobre o escravo. Por isso, este fica, de maneira geral, exposto aos caprichos de seu senhor e a todo tipo de violência. O proprietário pode chicotear, prender ou matar o escravo, pois sendo este uma propriedade, não pode recorrer a nenhuma ação no tribunal, exceto através do próprio senhor. No período imperial, são criadas leis que objetivam o abrandamento das punições contra os escravos; a partir de Augusto, os imperadores passam a decretar leis que visam a uma maior proteção contra os maus-tratos ${ }^{94}$.

escrava Harpaste (Epist. Mor. 50, 2/3), enquanto, o segundo matrimônio, nomeia e tece inúmeros elogios à esposa, afirmando que deveria cuidar de sua saúde, para viver mais tempo na companhia de Paulina, sua esposa (Epist. Mor. 104, 5).

${ }^{94}$ Cláudio (41-54) impede os senhores de matarem ou expulsarem os escravos doentes arbitrariamente. Vespasiano (69-79) proibiu a venda de escravas para a prostituição e Domiciano (81-96) a mutilação. Adriano (117-138) amplia a proteção física aos escravos fechando cárceres privados, salvo por autoridade judicial. Antônio Pio (138-161) fez com que 
Essa crescente mudança foi expressa em comentários sobre a escravidão feitos por juristas romanos (Florentino, Ulpiano) e por autores como Sêneca, Epiteto e Dion Crisóstomo que discorreram sobre o excesso e a brutalidade dos senhores contra os escravos. Sêneca, ainda que fosse um rico proprietário de escravos, insistia para que fossem tratados com moderação, sem excessos de punições. Aos olhos do pensador, são ignóbeis e cruéis os tratamentos desumanos que lhes são infligidos, como se não fossem humanos, mas bestas de carga (Epist. Mor. 47, 5/6) ${ }^{95}$. O filósofo interpreta o escravo como um amigo inferior. Em um diálogo imaginário com Lucílio, fez a seguinte afirmação:

os proprietários fossem responsáveis pelo assassinato de seus escravos e Diocleciano (285$305)$ proibi o abandono de crianças escravas. No entanto, como sugerem Gerard Boulvert e Marcel Morabito (1982), "aumentando as penas previstas contra aqueles que contribuem para a fuga dos escravos, o Estado vai, sobretudo intervir na busca dos fugitivos e sob os Antoninos, parece que a luta contra a fuga dos escravos se intensificou a ponto de os domínios privados, mesmo os dos senadores, atividade de bestiarius, não eram mais asilos (...) Com a permissão de Antonino, o piedoso, este ponto da lex Fabia e as autoridades administrativas vão receber a ordem de ajudar os mestres" (p. 106). Consultar: André Piganiol, 1973 e Jean Gaudemet, 1992 que trata sobre a posição do escravo no direito romano, babilônico, hebreu, assírio e grego. Além disso, consultar (JOLY, 2006, pp. 18-58) sobre a discussão historiográfica contemporânea com ênfase na escravidão. Nesta tese de doutoramento, o autor faz abordagens, com muita coerência, abordando três elementos centrais: escravidão e sociedade escravista, escravidão e cidadania e a escravidão e a cidade de Roma. PIGANIOL, André. "Les empereurs parlent aux esclaves". In: PIGANIOL, André. Scripta Varia, v. 3. Bruxelas: Latomus, 1973, pp. 202-11; GAUDEMET, Jean. "Esclavage et dépendance dans l'Antiquité". In GAUDEMET, Jean. Droit et société aux derniers siècles de l'Empire Romain. Nápoles: Jovene Editore, 1992, pp. 237-74; JOLY, F. Libertate opus est. Escravidão, Manumissão e cidadania a época de Nero (54 a 68 d.C.). São Paulo: FFLCH, 2006 (Tese de Doutoramento); ANDREAU, Jean. De l'esclavagisme aux esclaves gestionnaires. Topoi, 9, 1999, pp. 103-112.

${ }_{95} \mathrm{O}$ autor Keith Bradley (1997), da University of Victoria, interpreta as fontes iconográficas e literárias sobre a escravidão, pressupondo um diferencial. Para ele, "às vezes, a diferença entre o iconográfico e o convencional pode ser muito pequena. Com isto, quando Lúcio, o asno em Metamorphoses de Apuleio é colocado para trabalhar rodando um moinho, ele também está com os olhos vendados, da mesma forma que o cavalo na cena de Ostia (Met. 9, 11, uelata facie). A descrição de Apuleio $(9,12)$ com Lúcio equipara os escravos e suas condições de trabalho, que principalmente por causa de sua referência aos corpos brutalizados dos escravos é uma das mais angustiantes descrições deste tipo em toda literatura clássica, assume um grau a mais de autenticidade como resultado: as pás do moinho usam nada mais do que trapos, não muito diferente do escravo no relevo de Ostia que é mostrado usando simplesmente uma túnica minúscula sem manga" (p. 273). Detecta-se, neste sentido, a construção do escravo por um paradoxo. De acordo com a autora: "as imagens confirmam, todavia um dos grandes paradoxos da História da escravidão em Roma, na qual escravos brancos eram ubíquos na sociedade, visíveis aos milhares e proeminentes em muitas avenidas da vida, eles são, ao mesmo tempo, seres totalmente assujeitados e relegados pelos donos a uma vida de desonra, degradação e brutalidade à margem da existência" (p. 274). 
"São escravos". Não, são homens. "São escravos". Não, são camaradas. "São escravos". Não, são amigos mais humildes. "São escravos". Não, são companheiros de servidão, se pensares que todos estamos sujeitos aos mesmos golpes da fortuna ('Servi sunt'? immo homines. Servi sunt? immo contubernales. Servi sunt? immo humiles amici. Servi sunt? immo conservi; si cogitaveris tantumdem in utrosque licere fortunae) (Epist. Mor. 47, 1).

A escravidão para Sêneca ocorre, assim, pela falta de sorte. O indivíduo tornase escravo por uma causa social e não por sua condição natural. Mesmo em se tratando de um período histórico diferente daquele vivido por Sêneca, o conceito de escravidão natural, proposto por Aristóteles, ajuda-nos a compreender, pelo menos a título de contraposição, a concepção senequiana sobre o escravo. De acordo com o pensamento aristotélico, cada indivíduo tem uma capacidade natural: alguns são destinados à obediência, enquanto outros exercem a função de comandar. O escravo, por não possuir a capacidade natural de guiar-se a si próprio, deve ser conduzido (Política I, 13). Sêneca, pelo contrário, via no escravo um amigo inferior que se encontra em tal situação por duas condições: pela má sorte ou mesmo por injustiça social. Como sugere Bradley (1994),

os estóicos acreditavam que era possível tanto para o escravo quanto para o liberto cultivarem a virtude, o estatuto social não era impedimento para viver de acordo com a natureza, porque apenas a liberdade domesticada era a liberdade do espírito e estava disponível para todos (p. 135) ${ }^{96}$.

Sêneca, no entanto, compartilha com Platão a pressuposição de que "todo o rei descende de escravos, que todo escravo é descendente de reis" (neminem regem non ex servis esse oriundum, neminem non servum ex regibus) (Epist. Mor. 44, 4). Assim como todos os cativos possuem ancestrais

\footnotetext{
${ }^{96}$ Consular: GILIBERTI, Giuseppe. Servi della Terra: Ricerche per una Storia del Colonato. Torino: G. Giappichelli Editore, 1999; LÉVY-BRUHL, H. "Théorie de l'esclavage". In: FINLEY, M. I. (ed.). Slavery in Classical Antiquity. Cambridge: W. Heffer \& Sons, 1960, pp. 151-169; BRIQUEL, Dominique. "Petite histoire d'une grande idée: l'ouverture de la citoyennete aux anciens esclaves, source de la puissance de Rome". Acta Classica, 36, 2000, pp. 31/49.
} 
livres, basta retroceder a árvore genealógica que se encontraram os resquícios da servidão na nobreza e em seus dirigentes.

O homem é provido de razão e isto independe de sua condição de cavaleiro, liberto ou escravo, pois esses são apenas estatutos jurídicos derivados da ambição e da injustiça social (Epist. Mor. 31, 11). A natureza, aos olhos do pensador, divide-se em quatro tipos de seres: a árvore, o animal, o homem e o deus. Estes dois últimos, por serem racionais, diferem entre si por serem um mortal e o outro imortal, mas possuem natureza idêntica e, portanto, são dotados de perfeita razão (Epist. Mor. 124, 14).

O homem perfeitamente racional é aquele provido de virtude, que mantém o domínio sobre si, afasta-se de pensamentos inconstantes, sente-se contente consigo próprio. Daí contingências como a perda de terras, desprestígio, morte de amigos e até mesmo a escravidão não abalam o homem virtuoso, que continua livre. Para Sêneca: "uma alma tanto pode estar num cavaleiro, como num liberto, como num escravo. O que é, na realidade, um cavaleiro romano, um liberto, um escravo? Nomes nascidos da ambição e da injustiça" (Hic animus tam in equitem romanum, quam in libertinum, quam in servum, potest cadere. Quid est eques romanus, aut libertinus, aut servus? Nomina, ex ambitione, aut ex injuria nata) (Epist. Mor. 31, 11).

Podemos detectar dois sentidos para o conceito de escravização: aquele vinculado a falta de virtude, que conduz o homem à busca desenfreada pela riqueza, poder, luxo ou prazeres e aquele relativo à escravização propriamente dita. O fato de os escravos igualarem-se aos seus senhores, levando-se em consideração o aspecto racional e mortal, não implica que Sêneca os iguale no plano social. As diferenças são inúmeras no campo social. 
A inferiorização do escravo inclui a impossibilidade de dispor de seu próprio tempo, de não possuir o livre arbítrio, de não poder negar a importância do trabalho e de viver sob o estado de coação. De acordo com a posição filosófica de Sêneca, não haveria bem moral em qualquer ação que fosse realizada contra a vontade ou sob coação. Todo bem moral deveria ser voluntário. A falta de liberdade e o medo são sinônimos de escravatura e, portanto, não é um bem moral, não é viver racionalmente. De acordo com suas palavras, "não pode ser honrado o que não é livre, pois quem teme, serve" (non potest honestum esse, quodnon est liberum: nam quod timet, servit) (Epist. Mor. 66, 16).

Ainda que pareça contraditório com a afirmativa acima, Sêneca defende, igualmente, que uma alma elevada poderia encontrar-se em um escravo. Por isso, aconselha Lucílio o seguinte tratamento: "alguns deverão jantar contigo porque são dignos de ti, outros para que o sejam: algo de servil que persista neles devido às reações com gente baixa, à convivência com pessoas de bem acabara por eliminar" (Quidam coenent tecum, quia digni sunt; quidam, ut sint. Si quid enim in illis ex sordida conversatione servile est, honestiorum convictus excutiet) (Epist. Mor. 47, 15). Esta relação amigável com os escravos encaminha-os, na medida em que convivessem com Lucílio, as práticas do bem, eliminando assim os possíveis resquícios de servidão.

A ação moderadora do senhor gera a possibilidade de o escravo encaminhar-se à virtude, assim como o desmando e o desrespeito contra o escravo geram uma rede de injustiças, que ocorrem freqüentemente por uma inversão de valores (Epist. Mor.; De Clem. Pr. II, 1). 
Essa relação de moderação do senhor com o escravo pode, segundo a leitura senequiana, ser harmonizada com a prática do benefício. Este é um elemento imprescindível de constituição e ordenamento social, pois humaniza as relações entre agentes sociais. Aos olhos do pensador, os indivíduos não sabiam nem dar, nem receber um benefício (De Beneficiis I, I, 1) por haver interesses imediatos daqueles que ofereciam e os que recebiam as benesses. Observa-se o patrimônio e a conduta. O que tem importância é o valor moral dos atos e não o recebimento dos 'presentes' (De Beneficiis I, IX, 1) ${ }^{97}$.

Sêneca embora pontue a posição inferiorizada do escravo afirma que o senhor pode receber benesses dele. Tratava-se de um benefício doméstico (De Beneficiis III, I, 1). O filósofo argumenta da seguinte forma: relevante é o sentimento do benfeitor e não sua posição social (De Beneficiis III, XVIII, 2). A condição servil não diminui o valor do ato pelo fato de a alma ser autônoma, independente e livre em seus movimentos (De Beneficiis III, XX, 1).

A segunda argumentação funda-se na impropriedade de afirmar que um escravo, em nenhuma circunstância, pode ser benfeitor de seu senhor (De Beneficiis III, XVIII, 2). Se assim fosse, deveriam ser, igualmente, descartados os benefícios que o soberano recebe de seus súditos. De acordo com suas palavras: "Se o escravo não dá benefício ao senhor, então ninguém dá ao rei,

\footnotetext{
97 Nesse tratado, Sêneca enumerou vários tipos de benefício entre amigos, públicos, doméstico. Foram consideradas benesses: a doação de terra fértil, baixar o preço do trigo, dar pão a um esfomeado, doação de uma região em que passa o curso de água navegável ( $D e$ Beneficiis III, VIII, 2; III, XIII, 2). De acordo com Giuseppe Giliberti (1984), "o 'benefício' é apresentado como valor fundamental daquela sociedade, conforme a razão natural que deverá surgir do regime do rei-filósofo. Em cada momento da existência da relação, paralelamente aos vínculos impostos pela estrutura hierárquica da cosmópolis, opera uma disponibilidade natural para a solidariedade e colaboração, sem a qual a convivência seria impossível (...). A coerção, os interesses materiais, a mesma clementia principis, que é também a fonte indispensável de consenso político, não bastam para dar coerência ao edifício social. É o benefício que cumpre esta função (pp. 1843-44). Ainda segundo o autor, "a previsão mais ou menos desinteressada de restituição de um favor. O benefício não é de fato um objeto puro e simples de especulação abstrata, mas uma res socialis, um fator de socialização destinado a regular efetivamente as relações humanas." (p. 1846).
} 
nem um soldado a seu comandante. Que diferença faz o tipo de poder que domina, se todo poder vem de cima?" (Si non dat beneficium seruus domino, nec regi quisquam suo nec duci suo miles; quid enim interest, quali quis teneatur inperio, si summo tenetur?) (De Beneficiis III, XVIII, 3).

Sêneca posiciona em um mesmo patamar as relações entre súditos e imperador, soldado e general, pais e filhos, patronos e clientes e escravos e senhores. Isto se deve ao fato de o exercício de poder de quem se submete ao poder de outrem ser gerador de benefícios; tanto os indivíduos de condição superior, como os de posição inferior recebem e contribuem mutuamente e reagem, a favor ou contra ${ }^{98}$. As relações ocorridas entre os agentes sociais baseiam-se em interesses concretos, diferentemente da interpretação contemporânea de Paul Veyne que enxerga uma "generosidade espontânea" dos membros da elite que beneficiavam o povo (VEYNE, 1976).

${ }^{98}$ Como sugeriu Faversani (1998): "O escravo é colocado em uma condição social quasi contra natura. O homem que é posto longe do alcance da razão, sua característica primordial, escapa ao que the é natural (...) O escravo, colocado por principio em uma posição desumanizadora, é fonte de crise. Um homem desumanizado está em desacordo com a natureza, é, pois um erro" (p. 03).

Qualquer tipo de escravidão transforma o homem em uma condição contra natura, definida por Sêneca pelo excesso dos prazeres, vinho, alimentos, o culto pelo corpo, jogos (na sátira Apocolocyntoses, condena o imperator Cláudio por apreciar o jogo de dados) e não somente 0 escravo que não é dono de si próprio. A argumentação utilizada por Joly (2005) de que "Sêneca (...) não valoriza as atitudes dos escravos a fim de enaltecê-los como categoria social, já que, pelo contrário, a considerava a mais vil de todas. Ele não se dirigia a um público de escravos, mas a uma audiência composta pela aristocracia imperial, e, sendo assim, as referências fazem parte da formulação de um conjunto de valores éticos para o contexto do principado" (p. 79). Ainda segundo Joly (2006): "esse prisma pelo qual Sêneca vê a relação escravista, não é de se estranhar que considere o suicídio como a única via de livre-arbítrio aberta ao escravo, como se somente destruindo seu corpo ficasse totalmente livre do senhor. Essa idéia é expressa novamente mediante uma oposição entre escravidão do corpo e escravidão da alma. O suicídio do escravo é uma prova de que sua alma é livre e, nesse caso, a classe servil pode ser um manancial de exempla" (p. 126).

Essa argumentação, ainda que interessante, não pode ser compartilhada em nossa pesquisa, pelo fato de o escravo ser uma categoria social, independentemente de sua condição inferiorizada, o escravo é parte da sociedade. Um exemplo disso refere-se à questão do benefício, tanto o senhor quanto o escravo, poderiam oferecer e receber benesses, mesmo estando, o escravo, em uma condição inferiorizada. Mesmo que utilize em algumas situações o escravo como metáfora, assim o faz com todas as categorias sociais de sua sociedade contemporânea pelo fato de utilizar este recurso de linguagem como exemplos, que concentram significados relevantes sobre sua posição filosófica. 


\subsection{Os micropoderes no mundo dos escravos}

Mais do que pretender aproximar o escravo do universo da virtuosidade, Sêneca propõe uma relação mais humanizada que visa à fidelidade e o auxílio que os escravos possam prestar aos seus senhores (De Beneficiis III, XXVII, 4) e, também à supressão das possíveis reações deles contra os senhores ${ }^{99}$.

A cumplicidade do escravo com o senhor ocorre no momento em que

o primeiro é tratado com amizade. Mesmo sendo um amigo inferior daria em

troca a amizade e fidelidade. Sêneca afirma:

Antigamente quando os escravos conversavam, não só na presença, mas com o senhor, quando não se lhes cosia a boca, eles estavam prontos para estender seu pescoço e desviar o perigo iminente para sua cabeça; conversavam às refeições, mas calavam-se quando torturados. Surgiu depois aquele ditado, sinal da mesma arrogância: 'tanto são os inimigos quantos os escravos'. Não, eles não o são, nós é que fazemos deles nossos inimigos (At alli, quibus non tantum coram dominis, sed cum ipsis erat sermo, quorum os non consuebatur, parati erant pro domino porrigere cervicem, periculum imminens in caput suum avertere. In conviviis loquebantur, sed in tormentis tacebant. Deinde ejusdem arrogantiae proverbium jactatur: 'Totidem esse hostes, quot servos. Non habemus illos hostes, sed facimus') (Epist. Mor. 47, 4) ${ }^{100}$.

99 Silvano Faro (1996) afirma que "Sêneca lança um apelo ao comportamento prático do senhor (dominus) com relação ao escravo. O que importa é que tal comportamento deve ser caracterizado pela benevolência, solicitude, piedade; conta muito mais que a aceitação dos princípios (esses sim estóicos) já profundamente conhecidos como a unidade originária dos homens, a possibilidade da virtude de qualquer escravo oprimido, ou o princípio pelo qual o verdadeiro escravo como sendo aquele dominado pelas paixões e a verdadeira escravidão são próprias do espírito, da qual qualquer um pode ser usufruidor, enquanto que a verdadeira liberdade consiste no domínio da própria vontade" (p. 117). Em nossa opinião, mais do que propor uma relação de fidelidade, Sêneca evidenciava a cotidianidade, os conflitos sociais, mostrando lutas internas entre senhores e escravos.

${ }^{100} \mathrm{O}$ Estado mediante o recurso da Lei romana permitia extrair confissões de escravos sob tortura. Acreditava-se que somente quando torturado o escravo dizia a verdade. Segundo Finley (1991), "o silêncio é uma forma especial de defesa, que pode assumir feições mais explícitas, apegando-se, primeiramente, às exceções na prática e às limitações legais e, em seguida, ao fato de os advogados alegarem nos tribunais, quando interessava, que o testemunho sob tortura não tinha valor" (p. 98). De acordo com Finley, "não há, na verdade, razões que confirmem a freqüência da tortura. O que existe é apenas um campo aberto às disputas ideológicas, que nos é oferecido pelos poetas cômicos e oradores. Já as evidências romanas são tão variadas e esmagadoras que não permitem defesas muito especiais, além do silêncio ou quase silêncio. O velho Mommsen, escrevendo quase meio século depois de sua impetuosa História romana, quase não trata do assunto nas mil páginas de seu trabalho sobre a legislação penal: torturar criminosos, sem falar em testemunhos, era 'não apenas cruel, mas absurdo'" (MOMMSEN Apud FINLEY, 1991, p. 99). Não podemos realmente afirmar a recorrência 
Sêneca produz, nesse sentido, um retrato das benesses que um senhor pode receber de seu escravo. Este pode agir com justiça, coragem, manter os segredos de seus senhores, mesmo recebendo vantagens para delatar ou sob tortura, salvar a vida frente a um perigo eminente, ajudar o senhor a cometer o suicídio, entre outros (De Beneficiis III, XVIII, 4; III, XIX, 2/3). Esta proximidade garante a harmonia entre senhor e escravo, a manutenção da ordem, a supressão de possíveis reações destes contra os senhores e, por parte dos escravos, beneficia-os com o ganho da liberdade (De Beneficiis III, XXIII, 3-4), como serem tratados com respeito, benevolência, realizam ofícios menos desprezíveis como as artes liberais, não exercem atividades como a coleta de excrementos ou a escansão, expondo o escravo ao ridículo (Epist. Mor. 47, 07).

O resultado dos maus tratos rende aos senhores uma relação de inimizade com os escravos. Por isso, escreveu: "tantos são os inimigos quantos os escravos". Para Sêneca, a crueldade é recorrente (Epist. Mor. 47, $5)^{101}$. Os escravos tratados com violência, exclusão, crueldade, reagem em situações concretas como é o caso do nomenclator que erra propositadamente e não cumpre com suas obrigações ${ }^{102}$, além da infidelidade, da participação de

da tortura, no entanto, não se pode considerar sua existência a uma mera discussão retórica. Sêneca comentou com muita propriedade a tortura nos escravos e sua fidelidade aos senhores, mantinham-se calados, mesmo sob tortura (Epist. Mor. 47, 5).

${ }^{101} \mathrm{Em}$ outras passagens, Sêneca refere-se à violência dos senhores contra os escravos: "E já não falo dos tratamentos cruéis, desumanos que lhes são infligidos, como se eles não fossem homens, mas bestas de carga" (Alia interim crudelia et inhumana praetereo, quod ne tanquam hominibus quidem, sed tanquam jumentis abutimur) (Epist. Mor. 47, 5).

$102 \mathrm{Um}$ outro exemplo de descumprimento era a negligência de suas tarefas, para assistir aos jogos e, como critica Sêneca, aos imprudentes divertimentos de seus iguais (De Ira II, X, 1). O que demonstra certa liberdade de ação e movimentação do escravo (doméstico) na domus, levando-o a desobedecer às ordens, escolher o tipo de diversão e mais, decisão que o conduz a sair do espaço senhorial, ampliando seu leque de possibilidades para angariar vantagens e benefícios com as relações - com outros agentes sociais - no espaço público. Pode-se pressupor, por exemplo, acerca do controle do escravo, decidindo quem entraria ou não na domus (De Constantia Sapientis 14, 2), advir, não apenas da proximidade com o senhor, mas 
tramas contra seus senhores, da fuga, da insolência, do roubo, da vingança, do suicídio, entre outros (De Beneficiis I, III, 10; III, XVII, 4; III, XXVI, 2 e De Clementia). De acordo com o pensador, "o resultado é que esses escravos a quem se proíbe falar em frente do senhor, falam depois mal dele pelas costas" (Sic fit, ut isti de domino loquantur, quibus coram domino loqui non licet) (Epist. Mor. 47, 4).

Temos, por um lado, a violência, a exclusão, o afastamento, a crueldade, a irritação contra os escravos, que ocorrem na esfera privada, produzindo reações destes contra os senhores através do assassinato, do envenenamento, da calúnia, da ira, da denúncia, do descontentamento (Epist. Mor. 107, 5). Por outro lado, o senhor que prioriza ações como a clemência, a benevolência, o respeito para com os escravos, ganhava em troca o benefício da amizade, da fidelidade e da proximidade ${ }^{103}$. Sêneca considera reprovável desprezar

esse homem que chamas teu escravo, nasceu da mesma semente que tu, goza do mesmo céu, respira, vive e morre tal como tu? Tanto direito tens tu a olhá-lo como homem livre como ele a olhar-te como escravo. Quando do desastre de Varo, muitos homens de ilustre ascendência, que aspiravam a entrar no senado mediante a carreira das armas, foram vítimas da fortuna: um veio a ser pastor, outro guardador de choupanas. Vê se deves então desprezar uma condição social em que tu mesmo podes tombar no próprio momento em que a cobres de desprezo (istum quem servum tuum vocas, ex iisdem seminibus ortum, eodem frui coelo, aeque spirare, aeque vivere,

das relações conquistadas no espaço público, levando-se em consideração suas experiências fora da esfera privada.

${ }^{103}$ Essa proximidade do escravo com o senhor, poderia garantir-Ihe a liberdade. De acordo com Keith Bradley (1994), a liberdade poderia ser alcançada da seguinte forma: "a emancipação era possível de ser obtida pelos escravos, quer sejam homens, quer sejam mulheres. Uma segunda provisão estipula que uma pessoa que teve sua liberdade ordenada num testamento sob pagamento de uma soma em dinheiro pelo herdeiro estaria livre mesmo se o herdeiro alienasse o escravo, visto que o dinheiro era pago a terceiros. Fica claro o quanto é antigo o procedimento de libertar escravos por meio de testamento, mas mostra também que libertar um escravo, uma coisa normal, não era necessariamente considerada um ato de generosidade da parte de quem escreveu o testamento, mas uma diminuição do estado do herdeiro (ou de um terceiro) para o qual o reparo tem de ser feito. Em terceiro lugar, as regras para os ladrões apanhados em flagrante eram formuladas: enquanto um criminoso livre era açoitado e entregue à parte vitimada, um escravo era açoitado e depois executado [...] Finalmente, um tipo de tabu religioso contra os escravos indicava pela diretiva que os escravos eram proibidos de ungir os corpos" (p. 17). 
aeque mori? Tam tu illum videre ingenuum potes, quam ille te servum. Variana clade multus splendidissime natos, senatorium per militiam auspicantes gradum, fortuna depressit: alium ex illis pastorem, alium custodem casae fecit. Contemne nunc ejus fortunae hominem, in quam transire, dum contemnis, potes) (Epist. Mor. 47, 10).

Além de tratar sobre a questão da violência contra o escravo, Sêneca menciona o alto custo em mantê-lo na domus senhorial. Na obra De Tranquilitate Animi afirma que o único servo de Diógenes fugira e este, tão pouco, irritara-se:

nem pensou tampouco como aquele fosse descoberto em fazê-lo voltar: "É torpe", disse, "que Manes possa viver sem Diógenes e Diógenes não possa sem Manes". Parece-me ter ele dito: "Faze teu negócio, Fortuna: Nada junto a Diógenes agora é teu. Fugiu-me o escravo? Pelo contrário! Eu é que fiquei livre" (nec eum reducere, cum monstraretur, tanti putauit: 'Turpe est, inquit, Manen sine Diogene posse uiuere, Diogenen sine Mane non posse'. Videtur mihi dixisse: 'Age tuum negotium, Fortuna, nihil apud Diogenen iam tui est: fugit mihi seruus, immo liber abii) (Tranquilitate Animi VIII, 7).

O escravo doméstico necessita de roupas e alimentos de seu senhor (De

Tranquilitate Animi VIII, 8), o que encarece, segundo Sêneca, a vida de quem

os mantém: "tantos ventres de avidíssimos animais há que sustentar, comprar-

Ihes vestes e custodiar-Ihes as muito rapaces mãos e fazer uso dos serviços daqueles que estão chorando e detestando o trabalho"104 (tot uentres auidissimorum animalium tuendi sunt, emenda uestis et custodiendae

104 Os escravos domésticos exercem vários tipos de trabalhos, tais como: servos pessoais, tutores, cozinheiros, artesãos, arquitetos, médicos, cabeleireiros, músicos, filósofos, bibliotecários. Entre eles há o eunuco para atender as mulheres e aleijados que divertem os convidados com suas deformidades. Um homem rico precisa de pelo menos dois escravos para carregá-lo até o circo, mas geralmente entre oito ou dez o acompanham, por ostentação. Um escravo pode servir na propriedade do campo, outro na casa da cidade. A tropa da cidade é dividida em escravos que trabalham dentro da residência e aqueles que trabalham do lado de fora. Estes, por sua vez, podem ser subdivididos pela natureza de suas tarefas. Há hierarquias até mesmo dentro dos ofícios. Nas Epistulae Morales, Sêneca comentou um caso sobre nomenclatores, afirmando que: "jamais um nomenclator velho, daqueles que já não sabem o nome às pessoas e dizem o que lhes vem à cabeça, citaria tão erradamente os apelidos de família como Sabino fazia aos Troianos e aos Aqueus" (Nemo velutus nomenclator, qui nomina non reddit, sed imponit, tam perperam tribus, quam ille Tojanos et Achivos, persalutabat) (Epist. Mor. 27, 5). Podemos pressupor duas questões: a atividade de nomenclator é avaliada pela qualidade da memória do indivíduo, havendo, dessa forma, hierarquias quanto à capacidade do serviço e, em segundo, muito provavelmente, os escravos envelhecem no exercício da nomenclatura, perdendo seu valor inicial, quando jovens, pela gradativa perda de memória. Este fator leva-nos a concluir que, em algumas atividades, a idade é um diferencial, assim como o nomenclator. 
rapacissimae manus et flentium detestantiumque ministeriis utendum) (Tranquilitate Animi VIII, 8).

Temos duas questões interessantes: a primeira é a forma com que o filósofo refere-se aos servos tratando-os por animais, diferentemente, do discurso auferido nas Epistulae Morales, em que Sêneca comentava sobre a possibilidade de tornarem-se virtuosos e, portanto, serem vistos como seres humanos, racionais e mortais. A segunda questão gira em torno do descontentamento do escravo que trabalha chorando e detestando tal atividade. Ainda que viva em uma completa dependência reage contra o senhor por meio do descontentamento que produz o lamento, a ira, o suicídio, o roubo e a fuga entre outros.

Sêneca não fornece indicações sobre se essas ações contra os senhores são de caráter individual ou coletivo. Mas parece que as reações ocorrem no âmbito individual, como nesta passagem: "E não vai ficar indignado por ter de desembolsar alguma quantia para ultrapassar a soleira, ponderando que também em algumas pontes se deve pagar para prosseguir" (Nec indignabitur aliquid inpendere ut limen transeat, cogitans et in pontibus quibusdam pro transitu dari) (De Constantia Sapientis 14, 2). O filósofo deixa explícito que o nomenclator seleciona e suborna - através da cobrança de dinheiro - o visitante para que possa adentrar à casa de seu senhor. Isto resulta numa estratégia de afirmação social e expressa, igualmente, uma relação de poder, pois o escravo é, através de sua função, o agente social que controla, vigia e proíbe ou não a entrada de visitantes. O nomenclator, inserido neste espaço particular, detém poder ${ }^{105}$.

\footnotetext{
105 Como sugeriu Foucault (1986): "cada luta se desenvolve em torno de um pequeno foco particular de poder (um dos inúmeros pequenos focos que podem ser um pequeno chefe, um
} 
Sêneca teme que essas reações particularizadas se tornem reações públicas. Expressa este temor ao criticar os senadores por terem sugerido, há algum tempo, a diferenciação de vestimenta dos escravos. Citemos in extenso: "Outrora, decidiu-se por um parecer do Senado que um sinal na roupa distinguiria os escravos dos homens livres. Em seguida, ficou evidente quanto perigo nos ameaçaria se os nossos escravos começassem a nos enumerar" (Decretum est aliquando de senatus sententia, ut seruos a liberis cultus distingueret; deinde apparuit, quantum periculum immineret, si serui nostri numerare nos coepissent) (De Clementia III, XXII, 1).

Sêneca, embora utilize o possível levante de escravos como metáfora para explicar o perigo eminente das execuções provocadas pelo princeps, explicita a possibilidade de uma ação concreta por parte dos escravos contra os senhores, levando-se em consideração as atitudes individuais de descontentamento, suicídio e o fato de se encontrarem em maior número dentro da sociedade romana.

A reação dos escravos, segundo Sêneca, ocorre pela falta de moderação de seu senhor, assim como o princeps tirano provoca a rebeldia. A domus é vista como uma pequena res publica e, portanto, Sêneca ensina que:

O espírito humano é rebelde por natureza e, pelejando contra o que the é contrário e árduo, acompanha mais facilmente do que se deixa conduzir. E, como se dirigem os cavalos de raça e de boa estirpe melhor com um frio flexível, assim, espontaneamente, a inocência segue a Clemência por seu próprio impulso e a nação considera-a digna de preservá-la para si. Assim, por esta via, avança-se mais (Natura contumax est humanus animus et in contrarium atque arduum nitens sequiturque facilius quam ducitur; et ut generosi ac nobilis equi melius facili freno reguntur, ita Clementiam uoluntaria innocentia inpetu suo sequitur, et dignam putat ciuitas, quam seruet sibi. Plus itaque ha uia proficitur) (De Clementia III, XXII, 2).

guarda de HLM, um diretor de prisão, um juiz, um responsável sindical, um redator-chefe de um jornal) (...) As mulheres, os prisioneiros, os soldados, os doentes nos hospitais, os homossexuais iniciaram uma luta específica contra a forma particular de poder, de coerção, de controle que se exerce sobre eles" (pp. 75-8). 
Sêneca não nega as desigualdades sociais e é dessa forma que se dirigia a Nero propondo que deveria poupar de castigos os mais humildes: "que poupes alguns prazerosamente; que sintas repugnância em vingar-te de outros e, não diferentemente do que ocorre com os insetos, que suja quem os esmaga, tua mão também deve afastar-se deles" (quibusdam libenter parcas, a quibusdam te uindicare fastidias et non aliter quam in animalibus paruis sed obterentem inquinantibus reducenda manus est) (De Clementia III, XIX, 4). De acordo com a visão senequiana, o controle repressivo da República por si só não conteria toda energia potencialmente insurgente gerada por cada uma das desigualdades sociais, assim como a violência do senhor contra o escravo não resultaria em benefício. A ação moderadora, pelo contrário, envolve uma parcela da humanidade que é capaz de retornar ao bem, se fosse perdoada (De Clementia I, 1) Para Sêneca,

É louvável mandar nos escravos com moderação. E, no cativeiro, não se deve pensar até que ponto seria possível suportá-lo impunemente, mas até que ponto seria permitido pela natureza da eqüidade e do bem, que ordena poupar tantos os cativos, quanto os comprados por dinheiro (Seruis imperare moderate laus est. Et in mancipio cogitandum est, non quantum illud impune possit pati, sed quantum tibi permittat aequi bonique natura, quae parcere etiam captiuis et pretio paratis iubet) (De Clementia III, XVI, 1).

Sêneca mostra a Nero o ódio dos escravos por Védio Polião ${ }^{106}$. Segundo suas palavras:

Quem não tinha por Védio Polia ódio pior do que seus escravos, porque engordava as suas moréias com sangue humano e aos que, por qualquer motivo, o ofenderam, mandava atirar no que não era outra coisa senão um viveiro de serpentes? Que homem mil vezes digno de morte! Quer porque lançava seus escravos para serem devorados pelas moréias que ele haveria de comer, quer porque somente as criava, ali, a fim de alimentá-las desta maneira (Quis non Vedium Pollionem peius oderat quam serui sui, quod murenas sanguine humano saginabat et eos, qui se aliquid offenderant, in uiuarium, quid aliud quam serpentium, abici iubebat? $O$

${ }^{106}$ Como sugeriu Braren (1990), Védio Polião, "apesar de ser filho de libertos, conseguiu elevar sua posição social ata alcançar o grau de cavaleiro. Acumulou grande patrimônio e parece que foi amigo pessoal do imperador" (p. 69). 
hominem mille mortibus dignum, siue deuorandos seruos obiciebat murenis, quas esurus erat, siue in hoc tantum illas alebat, ut sic aleret) (De Clementia III, XVI, 2).

A intenção ao colocá-lo como exemplum é mostrar, entre outras coisas, a ameaça do ódio por parte do escravo e, assim, a possibilidade de este matar até mesmo o rei. Sêneca afirma que "o temor é uma situação tão ingrata em tua própria casa como no exterior, tanto por parte dos teus escravos como por parte dos cidadãos livres" (Timeri autem tam domi molestum est, quam foris; tam a servis, quam a liberis) (Epist. Mor. 105, 4) ${ }^{107}$.

As recomendações do filósofo para evitar a coação e os castigos em excesso, representam apenas medidas moderadoras, mas não a extinção deles. Em uma passagem, Sêneca fez a seguinte reflexão:

Faríamos, sem dúvida, uma grande coisa se nos apiedássemos dos infelizes escravos no ergástulo! Por que nos apressamos a castigar sem demora, a quebrar pernas sem cessar? (...) Vamos ao ferro, aos suplícios capitais e às correntes, castigamos pelo cárcere e pela fome o que poderia ser punido com os mais leves açoites (Magnam rem sine dubio fecerimus, si seruulum infelicem in ergastulum miserimus! Quid properamus uerberare statim, crura protinus frangere? (...) ad ferrum uenimus, ad capitalia supplicia et uinculis, carcere, fame uindicamus rem castigandam flagris leuioribus) (De Ira III, XXXII, 1/2) ${ }^{108}$.

Em relação ainda aos castigos aplicados contra escravos, Sêneca

menciona o personagem Platão. Citemos in extenso:

Platão, irritado com seu escravo, sequer esperou, e ordenou que o escravo levantasse a túnica e apresentasse as costas aos golpes, a fim de castigá-

${ }^{107}$ Os escravos injustiçados, abandonados ou em alguma situação de perigo abrigavam-se em frente de templos ou estátuas do soberano. Sêneca fez referência a este fato: "mesmo os escravos é permitido refugiar-se junto de uma estátua" (Seruis ad statuam licet confugere!) (De Clementia III, XVI, 2)!

${ }^{108}$ A alimentação, mesmo não se caracterizando por uma ação punitiva, é escassa. Sêneca fez a seguinte abordagem a Lucílio: "Então, Lucílio, podes crer que terá a satisfação de ver como matas a fome com dois ases, de compreender que, para viver em segurança, não precisamos da fortuna para nada. Mesmo quando hostil, a fortuna não nos nega o que é estritamente necessário. Procedendo assim, de resto, não há razão para pensares que fazes uma grande coisa, fazes apenas o mesmo que muitos milhares de escravos, que muitos milhares de pobres" (Lucili, exsultabis, dipondio satur, et intelliges ad securitatem non opus esse Fortuna: hoc enim quod necessitati sat est, debet [etiam] irata. Non est tamen quare tu multum tibi facere videaris: facies enim quod multa millia servorum, multa millia pauperum faciunt) (Epist. Mor. 18, 07). Sêneca em outro excerto fez referências aos alimentos ingeridos por escravos e pobres como o pão de centeio, a polenta e a água (Epist. Mor. 18, 10). 
lo com as próprias mãos; compreendendo que estava irritado para com a mão levantada na posição de desferir o golpe. Um amigo que então aparecera pergunta-Ihe o que estava fazendo: "Estou punindo", respondeu, "um homem encolerizado" [...] "Estou irritado", disse, "irei mais longe do que devo e voluntariamente; que este escravo não fique nas mãos de um senhor que não é senhor de si" (Non potuit impetrare a se Plato tempus, cum seruo suo irasceretur, sed ponere illum statim tunicam et praebere scapulas uerberibus iussit sua manu ipse caesurus; postquam intellexit irasci se, sicut sustulerat manum suspensam detinebat et stabat percussuro similis; interrogatus deinde ab amico qui forte interuenerat quid ageret: 'Exigo' inquit 'poenas ab homine iracundo' [...] 'Irascor'; inquit 'plus faciam quam oportet, libentius faciam: non sit iste seruus in eius potestate qui in sua non est) (De Ira III, 12, 5-7).

Como podemos observar, a violência contra os escravos é um dado recorrente na esfera privada. Sêneca busca humanizar as relações entre senhores e escravos, para mostrar à sociedade de seu tempo, os malefícios de uma conduta mais enérgica contra os inferiores ${ }^{109}$. Além de pregar a obediência para os escravos, como propõe Finley (1991, p. 125), a humanização senequiana pretende demonstrar que qualquer subalterno guiado pela falta de virtude é oprimido e autodestrói-se (De Clementia III, I, 5). A violência senhorial gera, por sua vez, duas situações insustentáveis: a violência incontida contra os escravos e o desequilíbrio de todo o ordo social que se desestabiliza com a recorrência dos vícios ${ }^{110}$.

${ }^{109}$ Segundo Carlo Castello (1984), "A humanitas já inspirava naquele tempo normas autoritárias que dispõem a liberdade sem manumissão do benefício desses [os escravos], seja impedindo o proprietário de cometer atos de brutalidade - e, em certos casos, também de torpeza - nos seus confrontos, seja não permitindo a quem declara diante de amigos querer libertar um escravo ao sujeitá-lo a sua dominica potestas" (pp. 2187-8).

${ }^{110}$ Compartilhamos com o seguinte aspecto proposto por Joly (2006): "O filósofo apresenta-se como um médico da alma, uma das metáforas mais recorrentes em sua obra, que busca sanar os vícios que desestabilizam o individuo e, por extensão, a comunidade humana. No De Ira diz que se deve corrigir, pelo sofrimento físico e moral, os caracteres depravados, tal qual o médico que amputa um membro para evitar que a doença se espalhe por todo o corpo $(\mathrm{I}, 6)$ " (p. 119). Joly propõe que a preocupação de Sêneca não era com os escravos, mas sim com os senhores. Em função disto, os escravos seriam metáforas (ibidem), não constituiriam um corpo social. Na seguinte passagem de Sêneca, citemos in extenso: "Sabes que Harpaste, a que pertencia a minha primeira mulher, continua em minha casa, pois o testamento obrigava-me a assumir esse encargo. Pessoalmente não sinto o menor interesse por estas pobres criaturas; se precisar de um bobo para me divertir não preciso ir buscá-lo muito longe: troço de mim mesmo! Ora a boba perdeu subitamente a vista. Podes não acreditar, mas a verdade é que a infeliz não percebe que está cega" (Harpasten, uxoris meae fatuam, scis hereditarium onus in domo mea remansisse; ipse inim aversissimus ab istis prodigiis sum: si quando fatuo delectari volo, non est mihi longe quaerendus: me rideo. Haec fatua subito desiit videre. Incredibilem tibi 
O escravo na esfera pública se liga, igualmente, as situações de violência, principalmente em locais em que são realizados os jogos gladiatoriais. Os gladiadores (a palavra vem do latim gladiolus, i espada curta, a arma geralmente utilizada pelo gladiador) são selecionados entre os escravos, prisioneiros de guerra e criminosos condenados. Estes são condenados à morte na arena por crimes como assassinato, traição, roubo, incêndio premeditado e sacrilégios. A rotina de confinamento e treinamento é relatada por Sêneca:

se o corpo pode, à força de treino, atingir um grau de resistência tal que permite ao atleta suportar a um tempo os murros e pontapés de vários adversários, que o torna apto a agüentar um dia inteiro sob um sol abrasador, numa arena escaldante, todo coberto de sangue (si corpus perduci exercitatione ad hanc patientiam potest, qua et pugnos pariter et calces non unius hominis ferat, qua solem ardentissimum in ferventissimo pulvere sustinens aliquis, et sanguine suo madens, diem ducat) (Epist. Mor. $80,3)$.

Esta rotina, muitas vezes, contrariam os gladiadores que se amotinam ou se suicidam para não se submeter ao destino que lhes é imposto. Sêneca, ainda que os considere pessoas de baixos extratos (Epist. Mor. 70, 22), enaltece um gladiador por cometer o suicídio. Citemos in extenso:

Recentemente deu-se um caso de um homem que ia numa carroça, rodeado de guardas armados, para participar no espetáculo da manhã; fingindo-se cheio de sono, pôs-se a cambalear no assento até que conseguiu meter a cabeça entre os raios de uma roda, e conservou-se firme até que a roda ao girar the quebrou o pescoço (Quum adveheretur nuper inter custodias quidam ad matutinum spectaculum missus, tanquam somno premente nutaret, caput usque eo demisit, donec radiis insereret, et tamdiu se in sedili suo tenuit, donec cervicem circumactu rotae frangeret) (Epist. Mor. 70, 23) $)^{111}$

narro rem, sed veram; nescit esse se caecam) (Epist. Mor. 50, 2, 3). De acordo com Joly, a Harpaste representa "um mero corpo, e, portanto apenas com características físicas, como a cegueira. Características essas que são transpostas, por meio de metáforas, para um plano moral circunscrito ao senhor, ou seja, a passagem acima se estrutura de acordo com as oposições alma/corpo e senhor/escravo (p. 126). Sêneca relatava a presença da escrava de forma pejorativa e zombeteira, mesmo assim, ainda o faz, o que representa, de alguma forma, uma certa relevância. Um individuo insignificante, se assim o fosse, como a escrava, sequer mereceria algum comentário. Sêneca, pelo contrário, se via obrigado, pelo testamento, a suportar a presença de Harpaste em sua casa e, além disso, referia-se à escrava pelo nome.

${ }^{111} \mathrm{Na}$ mesma carta, Sêneca fez referência a outros suicídios. Vejamos mais dois casos. O primeiro referia-se a um escravo que se matou por asfixia: "Não há muito, um dos Germanos 
suicídio é uma forma sensata de pôr fim à servidão, fosse escravo ou cidadão $^{112}$. Ambos podem escolher a melhor maneira para romper com os vínculos de qualquer escravidão, seja ela compulsória como é o caso do escravo ou aquela servidão munida pelo luxo, pelo excesso de prazer entre outras coisas (Epist. Mor. 70, 12/13). Como sugere Grisé (1982), "nada pode limitar a autonomia pessoal da razão" (p. 215). A autora acrescentou ainda que "Sêneca faz do suicídio um ato profundamente humano: adaptado à natureza das coisas, este ato funda a autarquia definitiva do indivíduo" (p. 218).

Os gladiadores são formados também por escravos, que não tinham escolha, a não ser pelo suicídio, de participarem ou não dos combates. São obrigados a prestar um juramento para suportar sem queixas o açoite, queimaduras ou morte, sendo o próprio treino, segundo Sêneca, um combate (Epist. Mor. 78, 16) $)^{113}$.

destinados aos combates com feras, enquanto se faziam no circo os preparativos para o espetáculo da manhã, retirou-se para satisfazer uma certa necessidade corporal - a única oportunidade que se teve para estar longe do olhar dos guardas; então agarrou num daqueles paus com uma esponja atada na ponta que se usam para limpar as imundices e enfiou-o pela garganta abaixo, morrendo de asfixia" (Nuper, in ludo bestiariorum, unus e Germanis, quum ad matutina spectacula pararetur, secessit ad exonerandum corpus; nullum aliud illi dabatur sine custode secretum: ibi lignum id, quod ad emundanda obscoena adhaerente spongia positum est, totum in gulam farsit, et vi praeclusis faucibus spiritum elisit) (Epist. Mor. 70, 20). Sêneca cita um outro exemplo nos combates de naumaquia: "Durante o segundo espetáculo de naumaquia, um dos bárbaros enterrou na garganta a lança que recebera para combater os adversários (Secundo naumachiae spectaculo unus e Barbaris lanceam, quam in adversarios acceperat, totam jugulo suo mersit.) (Epist. Mor. 70, 26)".

${ }^{112}$ Como afirmou Yolande Grisé (1982), "o suicídio terá a tendência a se apresentar como um ato 'razoável' porque surge da razão e com isto é altamente moral. Nem criminoso nem imoral, a morte por suicídio será considerada pelos estóicos do Império como a honesta mors do homem que foge da servidão" (p. 26). Como Sêneca retratou em suas obras, o suicídio não era exclusividade dos setores aristocráticos, mas um ato recorrente em todos os setores sociais. Grisé apontou quatro condutas para o suicídio: a primeira, denominada conduta de evasão que se definia por quatro situações intoleráveis, a saber: "uma derrota militar, uma grave ameaça de processo judiciais, de terríveis males físicos e desgosto pela vida" (p. 61); a segunda conduta ideológica, o suicídio político cometido por pessoas de alta posição do século I d.C. (p. 81); a terceira seria a ablativa referente ao suicídio sacrificial (e.g. o sacrifício de alguns escravos por seu senhor); a conduta agressiva que reunia três tipos de suicídio definidos pelo criminal, vingança e o suicídio de chantagem (p. 87) e, por último, as condutas lúdicas que se referiam aos suicídios ocorridos nos espetáculos gladiatoriais (p. 91).

${ }^{113}$ Garraffoni (2005), em seu estudo sobre gladiadores romanos, utilizando fontes da cultura material apresentou diversos artefatos que representavam as armas de combates, as vestimentas, a musculatura, a quantidade de personagens esculpidos e cenas apresentando 
Nesse ambiente de espetáculos o qual definimos como esfera pública, o escravo mantinha, de acordo com o pensamento senequiano, uma porção de poder. O público, de modo geral, recebia momentos de entretenimento, enquanto o escravo ganhava a vida e, em alguns casos, a glória. Esta era demarcada pela experiência do gladiador no espetáculo. Ao que tudo indica, havia uma hierarquia entre eles. Um exemplo disso é expresso no momento em que Sêneca ridiculariza Cláudio, afirmando que deveria receber como punição o chicoteamento por gladiadores noviços (Apoc. IX, 3). O que implica em mais um rebaixamento, além de ser chicoteado em um espetáculo, o que seria repulsivo para um aristocrata, deveria ser punido por um gladiador sem glória, sem experiência (Apoc. VIII, 1).

O gladiador relacionava-se com o público, pois podia apelar para a sua clemência (Epist. Mor. 37, 2) ou ser rechaçado. Segundo Sêneca, "os gladiadores, como diz Cícero, consideramo-los odiosos, se a todo custo desejam conservar a vida; aplaudimo-lo, se deixam claro que a desprezam" (Gladiatores, ut ait Cicero, inuisos habemus, si omni modo uitam impetrare cupiunt; fauemus, si contemptum eius prae se ferunt) (Ad Serenum De Tranquilitate Animi XI, 4). Lutava, igualmente, para conquistar o apreço do público, quer dizer, lutava por ambição de glória. De acordo com o pensador,

Quantas pancadas não apanham os pugilistas no rosto, e em todo o resto do corpo! No entanto, submetem-se a essa tortura apenas pela ambição da

músicos e dançarinos (pp. 162-3). Sêneca ainda que tenha apresentado uma interpretação diferenciada das fontes materiais, sugeriu, igualmente, a constituição de espetáculos não apenas pela violência, mas relatava a participação de músicos como flautistas e trompistas, característico de uma festa que produzia, segundo o filósofo, um canto harmônico. Damos voz a Sêneca: "E falo do coro tal como o conheceram os antigos filósofos, porque nos espetáculos de hoje participam mais cantores, a platéia fica rodeada de trompetistas e no palco se faz ouvir simultaneamente toda a espécie de flautas e outros instrumentos, todos estes elementos dissonantes produzem um canto harmônico" (De choro dico, quem veteres philosophi noverant. In commissionibus nostris plus cantorum est, quam in theatris olim spectatorum fuit: quum omnes vias ordo canentium implevit, et cavea aeneatoribus cincta est, et ex pulpito omne tibiarum genus organorumque consonuit, fit concentus ex dissonis) (Epist. Morales 84, 10). 
glória. E não apanham pancada apenas porque lutam, mas também para que possam lutar: o próprio treino já é uma tortura (thetae quantum plagarum ore, quantum toto corpore excipiunt? ferunt tamen omne tormentum, gloriae cupiditate; nec tantum, quia pugnant, ista patiuntur, sed ut pugnent: exercitatio ipsa tormentum est) (Epist. Mor. 78, 16).

Na concepção de Sêneca, o escravo pode alcançar a glória por meio da luta, isto no caso do gladiador, ou submeter-se ao suicídio como forma de liquidar o estado de servidão, para por fim à sujeição às atividades indignas. $\mathrm{O}$ que deveria ser uma prática no universo dos escravos, levando-se em consideração, alguns exemplos de suicídios relatados pelo filósofo. Em relação à viabilidade do suicídio, Sêneca escreveu da seguinte forma:

Nunca serei escravo! E comprovou as palavras em dialeto dórico, pelos atos: a primeira vez que o mandaram desempenhar um trabalho servil e indigno (tratava-se de ir buscar um vaso para excrementos) ele despedaçou a cabeça contra uma parede. Como pode alguém se sujeitar a ser escravo tendo a liberdade assim à mão (Non serviiam! sua illa dorica lingua; et verbis fidem imposuit. Ut primum jussus est fungi servili et contumelioso ministerio (afferre enim vas obscoenum jubebatur), illisum parieti caput rupit. Tam prope libertas est! et servit aliquis) (Epist. Mor. 77, 14/15) ? ${ }^{114}$

Sêneca mostra que os escravos são divididos por categorias, sendo a diferenciação dada pelo exercício de suas funções. O filósofo não explicita diretamente a categorização, mas observa desde a prática de atividades desprezíveis, como a coleta de excrementos até atividades liberais e manuais. O exercício delas é o resultado da excessiva ganância dos homens que colocavam outras pessoas nessa condição contra naturam e era, por isso, que existiam as mais diversas e inúteis atividades, por exemplo, o escravo que servia vinho,

vestido e pintado como uma mulher, luta contra a própria idade. Não o deixam crescer, forçam-no a manter-se criança, e, apesar do seu físico de soldado, todo depilado a ungüento ou à pinça, passa a noite em claro ao serviço da embriagues e da lubricidade do senhor: serve-lhe de homem no

\footnotetext{
${ }^{114}$ Como propôs Faversani (2000), Sêneca não fez referências à abolição desta instituição e sim soluções que o escravo tomava para a obtenção da liberdade: a fuga, a compra da liberdade pelo peculium e o suicídio - opção mais válida pelo filósofo ( $p$. 127).
} 
quarto, de garoto na sala de jantar (Alius, vini minister, in muliebrem modum ornatus, cum aetate luctatur: non potest effugere pueritiam: retrahitur: jamque militari habitu, glaber, retritis pilis, aut penitus evulsis, tota nocte pervigilat; quam inter ebrietatem domini ac libidinem dividit, et in cubiculo vir, in convivio puer est) (Epist. Mor. 47, 6) ${ }^{115}$.

Além de a escanção conduzir o indivíduo, na opinião senequiana, à situação de ridículo, há um outro elemento: a idade do escravo. Este deveria ser jovem e, ao mesmo tempo, próximo do senhor, mantinha relações sexuais o que lhe gerava um maior contato e uma maior obtenção de vantagens com a proximidade de seu senhor (Epist. Mor. 47, 07) ${ }^{116}$. Um outro exemplo de proximidade com o senhor foi o caso do escravo Felicião. Este pertencia a uma propriedade rural de Sêneca, dado a convivência, o filósofo considerava-o companheiro, no entanto, o afastamento provocou, tempos depois, o não

\footnotetext{
115 O horário do jantar é criticado por Sêneca pela excessividade de escravos que tinham por obrigação: limpar os escarros, vômitos e trinchar aves. Citemos in extenso: "quando jantamos estendidos no leito há um escravo para limpar os escarros, outro para, de quatro, andar apanhando o vomitado dos convivas ébrios. Outro se destina a trinchar aves de alto preço; e com sua mão hábil, por cortes exatos desde o peito até à mitra, vai fazendo a ave em pedaços. Desgraçado, cuja vida não tem outro fim que não seja trinchar aves!" Só que talvez ainda seja mais miserável o senhor que nisso adestrou para servir o seu prazer, do que o escravo forçado a adestrar-se" (quod quum ad coenandum discubuimus, alius sputa detergit, alius reliquias temulentorum subditus colligit, alius pretiosas aves scindit, et, per pectus et clunes certis ductibus circumferens eruditam manun in frusta excutit. Infelix, qui huic uni rei vivit, ut altilia decenter secet: nisi quod miserior est, qui hoc voluptatis causa docet, quam qui necessitatis disci) (Epist. Mor. 47, 5/6). Temos, igualmente, a prática do comércio, prostituição, cabeleireiro, barbeiro, cantor, porteiro, nomeador, camareiro e médico exercido por escravos (estas podiam ser exercidas por trabalhadores de origem livre e libertos). No caso da prostituição Keith Bradley (1994) fez a seguinte afirmação: "uma certa proporção de vernae deve sempre ter sido descendente de escravas que foram vitimadas por homens livres. A lei reconhecia que os escravos podiam ser sexualmente abusados por terceiros e dava aos senhores de escravos vários meios pelos quais garantia ser reembolsado por qualquer prejuízo sofrido pela propriedade - os próprios escravos obviamente não eram recompensados" (p. 49).

${ }^{116}$ Como afirmamos a idade é um elemento diferenciador entre os escravos, em algumas atividades como o carregador de liteira, podemos supor que é relevante tanto a jovialidade quanto a força física. Esta se torna necessária para deambulação e proteção do senhor. Sêneca critica e, ao mesmo tempo, autocritica-se em relação ao costume aristocrático: passear apenas em liteiras. Citemos: "Acabei de chegar de um passeio em liteira, tão cansado como viria se tivesse feito a pé todo o trajeto. Afinal também cansa andar as costas dos outros, e talvez ainda canse mesmo mais por ser antinatural: a natureza não nos deu os pés para andarmos, assim como nos deu os olhos para vermos por nós próprios? (A gestatione quum maxime venio: non minus fatigatus sum, quam si tantum ambulassem, quantum sedi. Labor est enim et diu ferri; ac nescio an eo major, quia contra naturam est; quae pedes dedit, ut per nos ambularemus: et oculos, ut per nos videremus " (Epist. Mor. 55, 1). Como sugeriu Joly (2006), "os escravos são considerados os pés do senhor, a ponto de Sêneca não dissociar o seu exercício físico daquele praticado pelos serviçais" (p. 122).
} 
reconhecimento de Felicião na velhice ${ }^{117}$. O escravo indaga-Ihe: "Não me conheces? Eu sou Felicião, a quem tu costumas oferecer bonecos, sou o filho do teu feitor Filosito, o teu pequeno preferido" (Non cognoscis me? inquit: ego sum Felício, cui solebas sigillaria afferre; ego sum Philositi villici filius, deliciolum tuum) (Epist. Mor. 12, 03).

Podemos supor duas questões: ainda que o filósofo não faça distinção de urbano e rústico, Felicião pertence à propriedade rural de Sêneca; em segundo, o escravo rural mantém um maior afastamento de seu senhor, enquanto, o urbano tem condições de manter proximidade e, com isso, obter mais vantagens e benefícios. Felicião é um exemplum, afastado do filósofo obtém apenas a indignação de seu senhor: "Belo" - digo eu - "este está doido; moleque e ainda por cima passando por meu companheiro preferido! Até esta correto: já Ihe estão caindo todos os dentes"! (Profecto, inquam, iste delirat! Pupulus etiam delicium meum factus est? Prorsus potest fieri: dentes illi quum maxime cadunt!) (Epist. Mor. 12, 03). Quando próximo de Sêneca, Felício era seu escravo preferido, distante, tornara-se um mero desconhecido. Sêneca ignora sua existência, sequer o reconhece ${ }^{118}$.

Temos outros casos de escravos que se relacionam com outras pessoas fora da domus como é o caso daqueles que inspecionam os convivas e determinam quem seria ou não convidado para um outro banquete (Epist.

${ }^{117}$ Segundo Bradley (1994), "para propósitos legais, os romanos dividiam os escravos em duas categorias, aqueles que pertenciam às famílias citadinas, a familia urbana, e aqueles que pertenciam à família rural, a familia rustica. A divisão era estabelecida de acordo com a concepção de que o típico senhor de escravo mantinha residência na cidade provida com escravos domésticos e possuíam propriedades de terras no campo que eram cuidadas, pelo menos em parte, pelos escravos" (p. 58).

${ }_{118} \mathrm{~A}$ dor de perder um ente querido era abrandada, segundo a concepção senequiana, mantendo próximo de si o escravo do outro. O que mostra, mais uma vez, a relevância da proximidade do escravo com o senhor. De acordo com as palavras de Sêneca, "o caso assemelha-se ao das pessoas que perderam alguém querido: a dor vai-se mitigando com o tempo, mas a presença do escravo favorito do falecido, a vista da sua roupa ou da sua casa, reavivam-na" (sicut dolorem lugentium, etiam si mitigatus est tempore, aut servuli familiaris admissio, aut vestis, aut domus renovat) (Epist. Mor. 49, 1). 
Mor. 47, 08). Isto Ihe dá autonomia e poder em relação a outros agentes, podendo determinar, dessa forma, relações clientelísticas de seu senhor, levando-se em consideração, o controle de entrada na domus.

\subsection{Ofícios: fatores de hierarquização entre escravos}

A crítica pelo excesso de luxo do senhor e o domínio de alguns escravos é resultado também do alto grau de especialização dos ofícios. Calvísio Sabino, criticado por Sêneca, pelo fato de adquirir escravos especializados em Literatura e considerar-se erudito. O que nos interessa é a informação de que estes escravos são comprados a preço de ouro (Epist. Mor. $27,05)$ e, portanto, o valor do trabalhador demarca-se pelo exercício do ofício. Um exemplo de escravos sem valor eram os negociados no templo de Castor:

Acaso eu me sentiria ultrajado se não me desse o devido tratamento algum desses sujeitos que negociam junto ao templo de Castor, comprando e vendendo cativos sem um pingo de valor, e cujas tabernas estão atulhadas com uma turba dos piores escravos? (Num moleste feram, si mihi non reddiderit nomen aliquis ex his qui ad Castoris negotiantur nequam mancipia ementes uendentesque, quorum tabernae pessimorum seruorum turba refertae sunt?) (De Constantia Sapientis XIII, 4)

O senhor podia preparar os escravos, através de instrutores que ofereciam treinamento especializado, para serem vendidos por um bom valor. Do ponto de vista do escravo, a aquisição de um ofício ou uma aptidão era a possibilidade, quando livre, de se sustentar.

Os escravos são também utilizados amplamente no comércio. No mercado encontram-se escravos em todo o tipo de loja, vendendo pão, carne, peixe, salsicha, vinho. Gerenciam lojas, negócios, casas de cômodos, 
armazéns $^{119}$, além, é claro, da tecelagem que é criticada pelo filósofo por produzir tecidos transparentes (Epist. Mor. 90, 20).

O grau de especialização dos ofícios fazia com que escravos fossem selecionados por categorias, como é o caso dos que trabalham no ambiente doméstico da casa imperial e da aristocrática, que podem ostentar luxo e um número elevado de servidores ${ }^{120}$. Existem equipes de escravos para cuidar das roupas, dos utensílios utilizados nas refeições, do tratamento de cada ornamento ou jóias, de cada etapa do toalete, do cozimento dos alimentos, do serviço de mesa, do entretenimento com música, da dança, das brincadeiras e das palhaçadas (Ad Paulinum de Brevitate Vitae; Epistulae Morales; De Constantia Sapientis; De Prouidentia).

Essas inúmeras atividades são criticadas pelo filósofo, pois seus contemporâneos às inventaram para suprir suas necessidades de luxo e ganância. Aos olhos de Sêneca, ter acesso a moradas soberbas de grandes senhores, concitar os favores de velhos sem herdeiros, ter influência no fórum

${ }^{119}$ Queremos destacar o seguinte aspecto: todos esses ofícios aparecem em Sêneca. No entanto, algumas atividades são explicitadas (e.g. escansão, conhecimento literário) e outras não como sendo praticadas por escravos. Supomos, nesse sentido, que o comércio como é destacado pelo filósofo no balneário (Epist. Mor. 56), devia ser praticado por escravos, assim como por trabalhadores livres e libertos. Além disso, devemos atentar ao aspecto da negociação. Esta conduzia os escravos a uma maior autonomia. Como sugere Bradley (1994), "no comércio do dia-a-dia - ou seja, em atividades como ser lojista, negociar e fazer transações bancárias - os escravos eram notáveis, operavam como gerentes e agentes de seus senhores com um enorme grau de latitude e independência" (p. 75).

${ }_{120}$ Ainda que Sêneca não comente diretamente sobre escravos imperiais, já que fez uma referência de que até um escravo poderia matar um rei (De Clem. III, XIX, 1), muito provavelmente, seria o escravo imperial, aquele que estivesse próximo do soberano, refere-se a importantes libertos, como o caso de Políbio, ligado a Cláudio, com um forte poder de influência nas decisões do soberano. O que leva autores como Bradley (1994) pressupor que, "a condição do escravo dependia do fato de que dentro da familia havia uma hierarquia ocupacional, na qual, digamos, o vilicus era reconhecido como superior ao pastor, o cubicularius ao ianitor, e este, por sua vez, dependia de uma série de trabalhos para os quais, geralmente, os escravos eram admitidos (...) Em Roma, os escravos que gozavam do mais elevado patamar na hierarquia eram aqueles que pertenciam ao maior e mais poderoso senhor de escravo do mundo, como o pai de Claudius Etruscus, e que tinha influência no governo do império romano" (p. 70). Ainda segundo a autora, "a vida material do escravo no mundo romano, como nas sociedades escravagistas, era determinada, por um lado, pela função dos escravos, posição e relacionamento com o senhor e, por outro lado, pelo grau de responsabilidade com o qual o senhor tem em relação às obrigações materiais relacionadas ao escravo" (p. 89). 
são formas efêmeras de poder que atraem a inveja e os pesares de pessoas indignas (Epist. Mor. 68, 10) ${ }^{121}$. Nada mais são, segundo o filósofo, que vícios enraizados e violentos caracterizados, igualmente, pela avareza e ambição. Tornam-se enfermidades crônicas para a alma (Epist. Mor. 75, 11 e 76, 32).

Essa preferência dos senhores por valores que se distanciam da virtude, perceptível em seu desmando e desrespeito geram uma rede de injustiças que ocorriam, freqüentemente, por uma inversão de valores. Os senhores detinham o poder supremo em sua domus e este poder revertia-se contra eles. Conduzindo os escravos pelos caminhos da opressão e do medo. Para Sêneca, a falta de virtude dos senhores é a causa das atitudes de insolência, suicídio entre outras ações desenvolvidas pelos escravos.

Sêneca propõe uma transformação de valores na sociedade a partir de ações que desenvolvam a moderação, a clemência, a recusa pelo luxo e a ostentação de riqueza por parte dos setores da elite, agentes sociais como os escravos - predispostos à violência e, conseqüentemente, à irracionalidade seriam conduzidos pelos caminhos da virtuosidade. O senhor teria, assim, segundo Sêneca, "amigos inferiores", predispostos a beneficiarem seus senhores por meio da amizade, da fidelidade, da proximidade, do respeito e da aceitação às ordens, desde que houvesse o mesmo tratamento por parte do senhor. Sêneca não pretendia eliminar a escravidão, e sim estabelecer uma relação harmônica entre senhores e escravos que lutam entre si, cada qual

${ }^{121}$ A situação de fome, segundo o filósofo, provocava o surgimento de inúmeras atividades. Citemos in extenso: "pois nesse caso podes socorrer-te desses homens a quem a fome ensinou novos ofícios: alguns deles te corrigirá o ritmo da marcha, outro observar-te-á a boca enquanto comes, enfim, a tantos pormenores estarão atentos quantos a tua paciência crédula permitir à sua audácia!" (Admitte istos, quos nova artificia docuit fames: erit qui gradus tuos temperet, et buccas et dentes observet, et in tantum procedat, in quantum ejus audaciam patientiae credulitate produxeris) (Epist. Mor. 15, 07). 
com suas armas, por seus espaços e poderes dentro de uma sociedade constituída, em essencial, por conflitos e negociações. 


\section{Libertos: expressões de poder no Principado Romano}

Nesse universo de conflitos, o escravo podia alcançar a liberdade e receber um novo status social, o de liberto ${ }^{122}$. Há inúmeros exemplos de sua importância na História Romana, sendo representado na cultura material e em fontes literárias. Nas obras de Sêneca, reconhecemos a participação deste nas esferas sociopolíticas sob duas formas: a do liberto imperial e a do liberto que vive a cotidianidade do comércio, das tabernas, afastados das relações com os setores aristocráticos. Trataremos primeiramente do liberto imperial.

Nossa análise sobre o liberto imperial se centra, em especial, na obra Consolatio ad Polybium, em que Sêneca se dirige a Políbio para amenizar seu sofrimento após a morte do irmão. O filósofo busca demonstrar, a partir de perspectivas estóicas, que é insano chorar pela morte de um ente querido. Sêneca propõe que não se deve lamentar o inevitável. "Cada um é enganado pela sua própria credulidade e naqueles que se ama, o esquecimento da condição mortal é voluntário; a natureza a ninguém declarou que o isentaria de sua condição mortal" (Sua quemque credulitas decipit et in iis quae diligit uoluntaria mortalitatis obliuio; natura nulli se necessitatis suae gratiam facturam esse testata est) (Consolatio ad Polybium XI, 1).

A morte é igualitária para todos os seres vivos. No entanto, atingiu um indivíduo em específico, o irmão de Políbio. Este, como vimos no capítulo

${ }^{122}$ De acordo com Bradley (1994), "a emancipação servia, primeiramente, aos interesses dos senhores de escravos que mantinham o sistema escravagista como um todo intacto e em ordem; era tanto 'um instrumento para obter cooperação por parte dos escravos ao mantê-lo como um prêmio que pudesse ser ganho', quanto 'um poderoso instrumento de dominação' que 'enfatizava a completa dependência do escravo ao seu dono'. Especialmente, no Rio de Janeiro, era comum aos donos libertar os escravos em troca de pagamentos ou de sujeitar a condições que satisfizesse as necessidades do dono, e em 1849 havia aproximadamente 10,000 homens e mulheres na cidade que eram ex-escravos" (p. 164). Consultar sobre escravidão no mundo antigo e moderno: SCHIAVONE, Aldo. La storia spezzata: Roma antica e Occidente moderno. Roma: Laterza, 1996. 
segundo, era um importante liberto à época de Cláudio. O discurso é, assim uma estratégia eficiente para o filósofo, pois o liberto poderia conseguir a clemência do imperator e, assim, facilitaria seu retorno do exílio a Roma. Queremos apenas pontuar, sem entrar no mérito da questão, a proximidade entre Políbio e Cláudio. De acordo com as palavras de Sêneca, "Políbio chora e sofre por algo, mesmo quando César é favorável" (Luget Polybius, et aliquid propitio dolet Caesare!) (Consolatio ad Polybium III, 5).

A função de Políbio, na casa imperial, era transmitir, ao príncipe, memoriais, requerimentos e súplicas dos cidadãos. Por isso, segundo a argumentação de Sêneca,

não te é lícito chorar para que possas ouvir muitos que choram, para que as lágrimas daqueles que estão em perigo e desejam obter misericórdia do mais brando dos Césares mereçam, teu cuidado. É preciso que seques tuas próprias lágrimas" (non licet tibi, inquam, flere: ut multus flentes audire possis, ut periclitantium et ad misericordiam mitissimi Caesaris peruenire cupientium lacrimae tibi sint curae, tuae assiccandae sunt) (Consolatio ad Polybium VI, 5) ${ }^{123}$.

Sêneca acrescenta que não apenas a ligação com César o projetou a mais alta esfera social, mas os estudos (Consolatio ad Polybium VI, 2). Temos dois elementos essenciais: primeiro, a qualificação de Políbio o conduz à projeção social, assim como também a atividade de memorialista gera proximidade e, com isso, benefícios do princeps; em segundo, a contigüidade com o princeps

${ }^{123}$ Segundo Fabre (1992), "o critério profissional permite medir, a propósito dos servidores imperiais, as possibilidades de ascensão de uma geração para outra. Aproximadamente quarenta inscrições indicam funções ocupadas pelos membros de uma mesma família: pai, filho, irmãos. Só se pode ser atingido pelo caráter hereditário de certas funções ou pelo pertencimento a um mesmo setor doméstico ou puramente administrativo" (p. 141). Queremos apenas acrescentar à afirmativa de Fabre, o caráter profissional permitir a sobrevivência e ascensão do indivíduo mesmo fora da esfera imperial, como veremos no subitem referente aos ofícios, hierarquias e possibilidades de ascensão do agente em cada atividade relatada por Sêneca, embora Fabre acentue o caráter hereditário das carreiras burocráticas e domésticas imperiais. Segundo o autor, "é essencialmente no seio da familia Caesares que se desenvolve as relações sociais; as amizades são dependentes das relações de trabalho e das estratégias profissionais. Não se faz nenhum esforço de aproximação ou integração entre os servidores imperiais (ou de seus filhos ingênuos) nas 'burguesias municipais', principalmente fora da Itália" (p. 157). 
conduz Políbio aos mais altos escalões sociais. É, portanto, insano chorar quando se tem o amor de César. Tal relação o leva a uma posição de destaque na sociedade. Por isso, deve, agradecer os favores de Cláudio (Consolatio ad Polybium VII, 1) e reunir seus feitos "para que, com um elogio familiar, sejam narrados por todos os séculos: o próprio César te fornecerá matéria e exemplo para ordenar e escrever, perfeitamente, uma obra histórica" (ut per omnia saecula domestico narrentur praeconio, quantum potes, compone; nam ipse tibi optime formandi condendique res gestas et materiam dabit et exemplum) (Consolatio ad Polybium VIII, 2) ${ }^{124}$.

Essa maneira de se refugiar da dor, escrevendo uma narrativa sobre os feitos de Cláudio, representa uma estratégia de articulação e negociação de poder fundamentada na adulação. Políbio, com seus enaltecimentos, cumpriria algumas metas: uma primeira é a possibilidade de se manter ao lado do imperator, assim também a segurança e as benesses de seus próximos estariam a seguradas. Sêneca faz a seguinte alusão a este fato: "Acrescenta, pois, a isto que, desde que declaraste que César te é mais caro que tua própria vida, não te é lícito queixar-se da Sorte, enquanto, ele viver. Com César vivo, todos os teus estão salvos, nada perdeste" (Adice nunc quod, cum semper praedices cariorem tibi spiritu tuo Caesarem esse, faz tibi non est saluo Caesare de fortuna queri. Hoc incolumi, salui tibi sunt tui, nihil perdidisti) (Consolatio ad Polybium VII, 4).

\footnotetext{
${ }^{124}$ Como sugeriu Werner Eck (1996), "a posição economicamente segura dos ex-patrões podia ser vantajosa para os libertos. Pelo menos no século I d.C., se pode crer nos dados oferecidos pelos romanos, não são poucos os libertos que acabavam por ser mantidos por um vínculo familiar e doméstico com seus patrões; qualquer coisa parecida pode se tirar do que disse Plínio. Se for verdade que isso resultava em dependência, os libertos viviam sob uma insegurança econômica e não podiam contar com patrões menos ricos. Ser liberto, mesmo na velhice, dependia do sustento diário, a exemplo de Plínio, da garantia social dada por meio de testamento destinada a uma parte dos libertos" (p. 166).
} 
A narrativa sobre os "belos feitos" de Cláudio cria, igualmente, uma imagem positiva de seu Principado. Dessa forma, todos ganham com esta projeção política: o primeiro beneficiário é Cláudio, que tem seu poder fortalecido e, assim, mantém sua potestas em segurança ${ }^{125}$, em segundo, Políbio garante suas benesses e sua posição política e social e, por último, Sêneca, pela boa sugestão, poderá retornar do exílio para a cidade de Roma, centro do poder político. Aos olhos do filósofo,

o dinheiro, a dignidade, o poder outras coisas frente às quais o desejo cego do gênero humano fica atordoado, são adquiridos com esforços, são vistos com inveja, enfim oprimem aqueles mesmos a quem ornam; mais ameaçam do que servem; são frágeis e incertos, nunca são tidos com segurança (pecunia, dignitas, potentia aliaque complura ad quae generis humani caeca cupiditas obstupescit, cum labore possidentur, cum inuidia conspiciuntur, eos denique ipsos quos exornant et premunt; plus minantur quam prosunt; lubrica et incerta sunt, numquam bene tenentur) (Consolatio ad Polybium IX, 5).

O que nos conduz a algumas conclusões sobre o modo como a complexidade social aparece em Sêneca. As categorias sociais, por um lado, são imprescindíveis aos contemporâneos do filósofo, sendo, portanto, relevante determinar a condição de livre, escravo e liberto. Sêneca demonstra, por outro lado, que a mobilidade social depende, em todo caso, da posição do agente na estrutura social. Sêneca, naquele momento do exílio, mesmo sendo ele um cavaleiro e Políbio um liberto, estava em uma situação inferior. Estava distante dos bastidores do poder político, enquanto o liberto, mesmo sendo de condição jurídica inferior, conseguira as boas graças do imperator que the

\footnotetext{
125 Podemos supor que o favorecimento de um liberto imperial conduziria à segurança da potestas de Cláudio, pelo menos, sob o ponto de vista simbólico: o imperator pelo fato de beneficiar um liberto, mesmo sob condições especiais, fabrica a imagem de que apóia, como um todo, o heterogêneo grupo de libertos. Criam-se, com isso, duas possibilidades: a identidade dos libertos, enquanto, grupo que é associado ao princeps pelo reconhecimento e consentimento e a presente idéia de que um liberto, mesmo com todas as limitações, tem condições de obter: honra, riqueza, reputação, popularidade e prestígio social, assim como Polibio Produz-se, dessa forma, uma expectativa de que todos os libertos podem alcançar igualmente altas posições e honrarias.
} 
garantia as benesses do poder representadas pelo dinheiro e pela dignidade ${ }^{126}$.

Essa mobilidade social marcada pela obtenção de dinheiro, dignidade e poder foi comprovada, diga-se de passagem, no momento em que Sêneca redigiu a Apocolocyntoses, escrita em 54 d.C., após a morte de Cláudio, como preceptor de Nero, tornara-se amigo do jovem imperador. Estando em uma situação privilegiada escreveu, contrariamente a Consolatio, uma sátira ridicularizando Cláudio por meio de críticas à ferocidade dos crimes cometidos contra a aristocracia. O personagem Augusto satiriza a ingenuidade dos deuses em querer divinizar Cláudio, um sujeito regido pela demência, incapaz de ordenar o próprio pensamento. Teriam um deus "nec cor nec caput habet" (Apoc. VIII, 1), isto é, uma divindade desprovida de razão e do dever ao bem público, uma obrigação regida pela comunidade de imortais e mortais. Cláudio teria sido in terris um modelo de soberano

\footnotetext{
${ }^{126}$ A mobilidade social dos libertos, de acordo com Pedro López Barja de Quiroga (1995), poderia ocorrer em conseqüência ao status social do patrono. Para o autor, os libertos tiveram um crescimento paradoxal devido às dificuldades legais e os contratos com os patronos (pp. 326-9). No entanto, identifica fatores como à criação de posições privilegiada e cargos na estrutura social e sua integração (p. 330), além da imigração dos descendentes para a Itália (p. 335) promoveram uma maior mobilidade e, por conseqüência, crescimento social. Segundo o autor: "esta é, penso eu, uma conclusão que deveria ser enfatizada, porque frequentemente é o estático caráter da sociedade romana que é enfatizada, com isto, limitar a mobilidade social a poucos grupos específicos, a saber, os primipilares e os libertos. Como resultado desta visão restrita, a mobilidade ascendente dos libertos não é vista como uma conseqüência do sucesso pessoal, mas como um efeito do estatuto de seus patrões (os libertos imperiais são o caso em questão), e dos laços produzidos pela lei da ajuda mútua que define a relação entre um exescravo e seu emancipador. Uma vez que a mobilidade social da plebs ingenua não pode ser facilmente detectada nas inscrições, conclue-se que nunca existiram, como se tudo fosse escuridão, simplesmente porque estamos cegos. Sabemos da existência dos decuriões cuja tribo indica uma origem estrangeira, outros que eram filhos de soldados e ainda outros cuja filiação mostra várias gerações de ancestrais livres. Admito que estes números não são mais do que uma meia dúzia, e nem há tanto certi decuriões" (p. 344).
} 
conduzido por trajetórias que se distanciam de uma política humanitária fundamentada na clemência ${ }^{127}$.

Na sátira, Cláudio volta a ser escravo de seu próprio liberto, sendo entregue a Calígula, "que o dá de presente a Éaco; e Éaco o entrega ao seu liberto Menandro, para que faça dele um esbirro na instrução dos processos" (Caesar illum Aeaco donat. Is Menandro Liberto suo tradidit, ut a cognitionibus esset) (Apoc. XV, 2). Aos olhos do pensador, reduzi-lo à condição de escravo é evidenciar seu anonimato, um soberano sem voz, conduzido e dominado por seus libertos ${ }^{128}$.

Sabemos que a crítica à participação destes nas decisões do governo (ainda que nunca pudessem ocupar o cargo de senador, apenas os descendentes de libertos), indica a influência nas negociações de $\operatorname{poder}^{129}$. $O$

\footnotetext{
${ }^{127}$ Não nos interessa se foi ou não hipocrisia de Sêneca escrever uma obra em que teceu elogios a Cláudio e tempos depois, uma sátira grotesca que o tratou como um tirano imbecil. O relevante, em ambas é demonstrar a importância dos libertos na constituição do poder.

${ }^{128}$ Como sugeriu Weaver (1981), os libertos imperiais "se elevaram de um status baixo de escravo a um posto secundário a serviço do imperador, ao status de liberto com uma posição responsável na burocracia; e alguns, por sua capacidade, que era normalmente capacidade para as finanças, e por sua relação legal e às vezes pessoal com o imperador, alcançaram postos de primeira classe desde os que exerciam uma grande influência, em alguns excessiva, sobre a estrutura do poder imperial" (p. 139). Ainda segundo o autor, "o salário normal não pode dar a resposta completa às enormes fortunas que se adquiriam frequentemente; as oportunidades financeiras e a perspicácia bem como a corrupção na medida certa representaram um papel significativo" (cf. pp. 145). Sêneca não comenta sobre os salários na obra Apocolocyntoses, mas citava a corrupção e a troca de favores dos membros do Senado e dos libertos imperiais.

${ }^{129}$ Como sugere a análise de Joly, "os descendentes de libertos não eram barrados do acesso à magistratura, a despeito das dificuldades que tinham de enfrentar, como os direitos dos patronos à herança dos libertos, o que podia afetar a transmissão de propriedade para seus descendentes (...) Pode-se ao menos apontar como os libertos tiveram um papel na renovação da elite no Império, tomando-se o exemplo de cidades como Ostia, Puteoli e Pompéia" (QUIROGA, 1995 Apud JOLY, 2005, p. 48). O autor argumenta ainda que a oligarquia de famílias foi sendo substituída de forma heterogênea e, em grande parte, por descendentes de libertos. Ademais "os ordines decurionum - cujos membros exerciam as magistraturas municipais - não podiam ser preenchidos apenas pelas famílias de maior prestígio social e econômico, uma vez que os indivíduos que os compunham acabavam por ascender a postos elevados na carreira eqüestre - para não mencionar o problema, nada desprezível, da própria reprodução - deixando atrás de si um vácuo, que era então suprido por elementos com um passado servil ou mesmo da plebe ingênua, que tivessem meios financeiros para tanto demográfico" (cf. p. 49). O próprio Sêneca afirmava que o homem deveria ser avaliado pela virtude, pelo fato de até mesmo os reis poderem advir da classe servil o que comprova a perspectiva apresentada por Joly, além de romper com aquelas propostas de que a elite
} 
pedido ‘indireto' de Sêneca a Políbio para que retornasse a Roma, indica seu prestígio no governo de Cláudio (Consolatio ad Polybium XIII, 3). Este poder de negociação reverte-se, igualmente, em riqueza. Na obra Ad Serenum de Tranquilitate Animi, Sêneca coment que Demétrio, liberto de Pompeu, supera a riqueza de seu antigo dono. Citemos in extenso:

Chamas mais feliz Demétrio, o liberto de Pompeu, que não se envergonhou de ser mais rico que seu senhor? Diariamente se lhe dava conta, como um general de exército, do número de escravos, a ele para quem pouco antes as riquezas deviam ser dois substitutos e uma cela mais larga (Feliciorem tu Demetrium Pompeianum uocas, quem non puduit locupletiorem esse Pompeio? Numerus illi cotidie seruorum uelut imperatori exercitus referebatur, cui iamdudum diuitiae esse debuerant duo uicarii et cella laxior) (De Tranquilitate Animi VIII, 6).

Os libertos são homens livres e suscetíveis de se integrarem ao resto da população livre do Império, com a possibilidade de enriquecimento. Continuam, no entanto, com a mácula da escravidão. São, freqüentemente, ridicularizados nas fontes literárias como Satyricon de Petrônio, com seu personagem Trimalquião, ou nas Epistulae Morales, de Sêneca que informa ironicamente: "Lembro-me ainda de um ricaço, Calvísio Sabino, de sua graça! Este homem tinha os bens de fortuna e o caráter próprio de um liberto" (Calvisius Sabinus memoria nostra fuit dives: et patrimonium habebat libertini, et ingenuim) (Epist. Mor. 27, 5). Na mesma obra, Sêneca comenta sobre Calisto, o liberto de Calígula, que no tempo de Cláudio, desempenha um cargo importante na administração; o seu ex-senhor, cujo nome ignoramos, tinha-o vendido; logo que se converte em poderoso liberto imperial, Calisto se vinga dele, obrigandoo a esperar para ser atendido (Epist. Mor. 47, 9). Os aristocratas ficam presos ao poder de antigos escravos, que guindados de um salto aos degraus do subalternos que seriam, contrariamente, heterogêneos e sem relevância social. 
trono, cobertos de bens e honrarias, como Narciso ou Palas, por seu trabalho oculto e soberano.

Temos dois discursos, a priori, contraditórios: em um primeiro momento, o liberto é tratado com ironia e em outro, pelo contrário, Sêneca apóia-o contra o ex-senhor, que teve o que merecia. Aos olhos do filósofo, o indivíduo deve ser avaliado não pela condição social e sim pela virtude (Epist. Mor. 31, 11). Continuam, ainda que pudessem obter a virtuosidade, como amigos inferiores. Não é um mero acaso que Sêneca critique a presença dos libertos nos altos escalões da República.

Extrapolando o espaço político, os libertos fazem parte de um grupo economicamente ativo, exercem atividades de lojistas, artesãos, grossistas, retalhistas, taberneiros entre outras e mesmo que não possuem um estatuto de notável influenciam na sociedade. Disto resulta, segundo Sêneca, a exigência de termas luxuosas, especialmente, àquelas destinadas aos libertos com uma

quantas estátuas, quantas colunas que nada sustentam, apenas decorativas, só para a exibição de riqueza. Que abundância de água caindo ruidosamente em cascatas! Chegamos ao luxo de só poder pisar pedras preciosas! (quantum statuarum, quantum columnarum est nihil sustinentium, sed in ornamentum positarum, impesae causa! quantum aquarum per gradus cum fragore labentium! Eo deliciarum pervenimos, ut nisi gemmas calcare nolimus) (Ep. Mor. 86, 7)!

Essa referência ao luxo, retirando de seu discurso o exagero literário, podemos supor que tanto libertos quanto plebeus enriqueciam, independentes de estarem ligados à casa dourada, isto é, a domus imperial. Como citamos anteriormente, é recorrente em suas afirmações que a prosperidade recaísse sob a plebe ou os talentos medíocres (De Prouidentia IV, 1) ou comentários de que a riqueza não é um bem, por isso, quem a detém são indivíduos como o cafetão Élio (De Prouidentia V, 2). Estes recursos, embora fossem considerados escusos pelo filósofo, mostram que os setores populares não 
sobrevivem do pão e do divertimento oferecidos pelos notáveis (Ad Paulinum de Brevitate Vitae, De Constantia Sapientis, De Prouidentia, Epistulae Morales). Visão estereotipada construída ao longo da História ${ }^{130}$. O caso de Calisto que obrigava seu antigo dono esperá-lo para ser atendido, evidencia a estreita relação de libertos com os membros da aristocracia, mesmo não possuindo o status social de ingenus, conseguem vantagens e benefícios econômicos que obriga seu antigo dono esperá-lo como um simples cidadão. A crítica ao acúmulo de riquezas e ao luxo das termas, exigido pelos libertos, demonstra, mesmo que estivessem nos bastidores políticos ou exercendo atividades desprezadas pelos notáveis, realizam negociações de afirmação social e vivem de seu pecúlio ${ }^{131}$.

Ainda que estejamos abordando sobre os setores subalternos em geral, não podemos ignorar o fato de os libertos serem depreciados e isso

\footnotetext{
${ }^{130}$ A "distinção natural" de Bourdieu influenciou interpretações como as de Paul Veyne sobre o liberto romano. Para Veyne (1990), a "rebelião e a luta de classes eram impensáveis. A natureza social criou uma série de papéis mais ou menos invejáveis e a sorte individual designou o homem destinado a assumir cada um deles; nada se podia fazer nem contra esta nem contra aquela. Assim, cada qual se aceitava e admitia candidamente a sua condição, para depois se gabar do modo como representara o seu papel. 'Eu não era um liberto, confesso', diz um epitáfio já citado, mas a minha sombra foi nobilitada por ter sido Cotta como patrão" (p. 41) Veyne acrescenta "ainda que bem sucedido, continua a ser liberto; não procura sair da sua classe e integrar-se, ainda que apenas em intenção, na boa sociedade, isto é na sociedade dos homens livres: levando uma vida luxuosa, ele manifesta a pertença a uma boa sociedade de libertos" (ibidem).

Os libertos ricos, segundo Veyne, não vendo um futuro fora de sua condição, inventam como Trimalquião de Petrônio, uma boa sociedade adaptada ao mundo dos libertos. De acordo com suas palavras, Trimalquião reproduz na sua categoria: "abandona os negócios, vive de rendimento das terras e imita o nível de vida dos grandes" (p. 42).

Veyne com uma postura elitista ignorou que a inferiorização decorria por parte da aristocracia romana, tendo em vista as fontes documentais serem de cunho elitista e não dos libertos, dos escravos e da plebe. Uma situação são os notáveis ridicularizarem os setores subalternos, outra, completamente distinta, é a inferiorização ocorrer pelos próprios agentes subalternos.

${ }^{131}$ Discordamos de proposições como a de Jean Andreau (1992) na qual afirma que "muitos libertos não passavam de pessoas do povo, pobres e desprezadas. Mas, salvo raras exceções, aqueles que escapavam a esse destino comum só o conseguiu graças a laços pessoais, a relações clientelares e de patronagem" (p. 152). Isto é, afastados do núcleo do poder não teriam nada a oferecer, principalmente, pelo fato de as trocas entre os agentes ocorrerem sempre no seio da elite ou entre os mais ricos com os menos ricos. Se assim fosse, qual a relevância de serem citados e discutidos nas fontes documentais?
} 
mostra, justamente, o grau de ascensão, popularidade e participação deles nos espaços social, político e econômico. Em Sêneca encontramos uma visão muito mais articulada e complexa de libertos como também da plebe e dos escravos, do que aquela tradicional e assumida por boa parte da historiografia contemporânea, que se resume aos dois elementos centrais: alimentação e diversão.

Terminada esta seção, discutiremos o exercício de ofícios realizado pelos setores subalternos como forma de sobrevivência na sociedade romana, para mostrar, fundamentalmente que estes criavam regras de estratégias que extrapolavam o universo das doações realizadas por agentes sociais como o imperator ou grupo de notáveis. 


\section{Ofícios: meios de sobrevivência e estratégias de afirmação social}

Seus olhos embotados de cimento e tráfego. Sentou pra descansar como se fosse um príncipe

(...) bebeu e soluçou como se fosse máquina

(...) e se acabou no chão feito um pacote tímido

Agonizou no meio do passeio náufrago

Morreu na contramão atrapalhando o público.

Chico Buarque

Construção

O debate estabelecido pela historiografia contemporânea sobre a distribuição de trigo e outros víveres pelo princeps ou grupos de notáveis à plebe, tornando-a passiva e ociosa, é recorrente. No entanto, a distribuição contempla uma minoria populacional. O critério de seleção fundamenta-se em dois fatores: a condição de cidadão e a obrigatoriedade de habitar em Roma. Uma outra questão é a impossibilidade de beneficiários sobreviverem com apenas cinco modii (aproximadamente 21 litros) de trigo distribuído pelos governantes (FAVERSANI, 1999).

Além das restrições governamentais, os pobres não conseguiriam transformar o trigo em pão. Morando em vivendas que não comportam cozinhas; os apartamentos das insulae, sempre sob o risco de incêndios, abrigam uma população, geralmente, miserável, com vestuário e alimentação escassos, cujos haveres são parcos ${ }^{132}$. Sêneca, dialogando com Lucílio sobre a possibilidade de viver sem fortuna e sem aparatos de luxo, utiliza como parâmetro de comparação a quantia irrisória de dois ases que pobres e escravos destinam para a alimentação diária. De acordo com suas palavras,

\footnotetext{
${ }^{132}$ Segundo Brunt (1989), sob o ponto de vista jurídico, os pobres tinham oficialmente o direito a um tribunal, no entanto, "o direito de recorrer aos tribunais não tinha muito valor para os pobres, que podiam ignorar seus direitos legais, não tinham nem tempo nem dinheiro para abrir o processo, perdidos nos tribunais, longe de casa, e não dispondo de dinheiro e influência com os quais podiam modificar o curso da justiça" (p. 191).
} 
Então, Lucílio, podes crer que terá a satisfação de ver como matas a fome com dois ases, de compreender que, para viver em segurança, não precisamos da fortuna para nada. Mesmo quando hostil, a fortuna não nos negão que é estritamente necessário. Procedendo assim, de resto, não há razão para pensares que fazes uma grande coisa (fazes apenas o mesmo que muitos milhares de escravos, que muitos milhares de pobres) (Lucili, exsultabis, dipondio satur, et intelliges ad securitatem non opus esse Fortuna: hoc enin, quod necessitati sat est, debet [etiam] irata. Non est tamen quare tu multum tibi facere videaris: facies enim quod multa millia servorum, multa millia pauperum faciunt) (Epist. Mor. 18, 07).

Para o filósofo "não é agradável viver de água, polenta, de pedaços de pão de centeio" (Non enim jucunda res est aqua et polenta, aut frustum hordeacei panis) (Epist. Mor. 18, 10). Sêneca relata que seus contemporâneos, a maioria de pobres e escravos, sobrevivam com a quantia discreta de dois ases e ingerindo alimentos extremamente simples, se comparados à cozinha da elite romana $^{133}$. Estes indivíduos, "a quem tudo falta" (De Clem. Pr. I, 3), não

${ }^{133}$ Sêneca faz críticas à sofisticação da comida e a inutilidade do cozinheiro conhecer técnicas especiais para o corte de carnes, mostra, igualmente, o grau de especialização que cada ofício deveria possuir, assim como o cozinheiro. Além disso, como afirmamos anteriormente, a proximidade do escravo é relevante, tanto é assim, que Sêneca afirma sobre a existência de escravos prediletos dos senhores. Citemos in extenso: "Nem, por hércules, considero seus festins como tempo livre, uma vez que vejo com quanta solicitude dispõem a prataria, quão diligentemente ajeitam as túnicas de seus jovens escravos prediletos, quão ansiosos ficam por saber como o javali sai das mãos do cozinheiro, ou com que velocidade os escravos jovens, a um dado sinal, correm às suas obrigações, com quanta perícia as aves são cortadas em bocados não muito grandes, ou quão cuidadosamente os infelizes escravos limpam o vômito dos bêbados" (Conuiuia me hercules horum non posuerim inter uacantia tempora, cum uideam quam solliciti argentum ordinent, quam diligenter exoletorum suorum tunicas succingant, quam suspensi sint quomodo aper a coco exeat, qua celeritate signo dato glabri ad ministeria discurrant, quanta arte scindantur aues in frusta non enormia, quam curiose infelices pueruli ebriorum sputa detergeant) (Ad Paulinum de Brevitate Vita XII, 5).

Essa critica senequiana indica, sobretudo, rituais para a realização dos banquetes e diferenciações entre comida e cozinha. Como sugeriu o antropólogo DaMatta (2004), em estudo acerca do hábito alimentar no Brasil, podendo em termos teóricos, ser comparado à sociedade romana, afirma que: "O alimento é tudo aquilo que pode ser ingerido para manter uma pessoa viva; comida é tudo aquilo que se come com prazer, de acordo com as regras mais nobres de preparo, serviço e comensalidade. O alimento é a moldura; mas a comida é o quadro, aquilo que é valorizado dentre os alimentos; o que deve ser saboreado com os olhos e, depois, com a boca, o nariz, a boa companhia e, finalmente, a barriga" (p. 31). A historiadora Regina Bustamente, no V Encontro Nacional do GT de História Antiga da ANPUH, realizado em abril de 2006, promovido pelo departamento de História da Universidade Federal de Goiânia, apresentou um trabalho intitulado - "Comida, diversão e arte" entre a elite no Império Romano: análise comparada de textos escritos e imagéticos" - em que analisou alguns mosaicos africanos sobre alimentos e propôs, justamente a diferenciação sugerida pelo antropólogo: alimento servia para sobrevivência do indivíduo, enquanto, a comida associava-se ao luxo e ao prazer, demonstrando, dessa forma, uma perspectiva semelhante do que foi apresentada por Sêneca. 
devemos rotular ou mesmo generalizar como uma multitudo de analfabetos, vivendo das redistribuições promovidas pelo ricos e pelo Estado (cf. GAGÉ, 1964; RostovtZefF, 1967; Wallace-HadRIL, 1990).

Assim é evidente que os agentes subalternos desenvolviam estratégias de sobrevivência, extrapolando o universo de doações e divertimentos nos espetáculos. Uma prova disso é a discussão senequiana sobre a obtenção da virtude através do trabalho. Por isso, a valorização ou não do ofício, seja ele qual fosse, dependia do alcance desta, do conhecimento de si (Epist. Mor. 31, 04). O ponto crucial em seu pensamento é o estudo ou mesmo a prática de ofícios que encaminhem à uirtus. Se o trabalho não fosse recorrente na sociedade romana, qual a relevância de Sêneca discutir sobre o papel do ofício para obtenção da virtude, ou seja, até que ponto as atividades eram essências para o crescimento da alma?

Há, em Sêneca, uma crítica moral ao trabalho. Sêneca afirma: "O trabalho não é um bem em si mesmo. Por isso eu desprezo toda a atividade vazia de sentido" (Labor bonum non est: quid ergo est bonum? Laboris contemptio) (Epist. Mor. 31, 04). Esta critica recaí sob a utilidade de qualquer ofício que não atinja a virtude. A filosofia, segundo a concepção senequiana, conduz o indivíduo à segurança, enquanto o ofício de arquiteto, por exemplo, à insegurança até mesmo física (Epist. Mor. 90, 08).

5. 1. Ofícios: artes liberais, manuais e de prazeres

Sêneca, além de caracterizar os ofícios por parâmetro moral, divideos, mais conceitualmente, em artes liberais, manuais e de prazeres. Trataremos primeiro das artes liberais. São elas: grammaticus (Epist. Mor. 88, 
3/4), geometricus (Epist. Mor. 88, 10), astrlogus (Epist. Mor. 88, 14) ${ }^{134}$, mathematicus (Epist. Mor. 88, 28), medicus (Epist. Mor. 95, 15) e musicus (Epist. Mor. 88, 9) ${ }^{135}$.

O filósofo parte do pressuposto de que as artes liberais são dignas

de um homem livre, refere-se em essencial à sabedoria. Citemos in extenso:

Compreendes por que razão se Ihes chama "estudos liberais": porque são dignos de um homem livre. No entanto, o único estudo verdadeiramente liberal é aquele que torna o homem livre; e esse é o estudo elevado, enérgico, magnânimo da sabedoria (Quare liberalia studia dicta sint, vides: quia homine libero digna sunt. Ceterum unum studium vere liberale est, quodo liberum facit; hoc sapientiae, sublime, forte magnanimum) (Epist. Mor. 88, 2)

Vejamos o porquê. A gramática dedica-se à análise de divisão de sílabas, à observação dos significados e ao conhecimento de temas mitológicos que não auxiliam, segundo Sêneca, a libertar-se do medo e a

134 Sêneca utilizou a seguinte argumentação: "Passemos agora ao especialista no conhecimento dos astros, aquele que sabe onde vai ocultar-se o gélido astro de Saturno, as paragens celestes por onde erra deus de Cilene"! Que me adianta este saber? (venio nunc ad illum, qui coelestium notitia gloriatur: Frigida Saturni sese quo Stella receptet, quos ignis coeli Cyllenius erret in orbes. Hoc scire quid proderit?) (Epist. Mor. 88, 14) Este grau de especialização dos ofícios, neste caso o de astrólogo, retratado por Sêneca pode ser, igualmente, comprovado nas lápides. Garraffoni em seu estudo sobre gladiadores constatou a partir das lápides funções especificas para a realização dos jogos gladiatoriais, o que demonstra a importância e a complexidade dos ofícios na sociedade romana. Segundo a autora, "os registros remanescentes nos fornecem indícios das diversas repartições ou cargos, bem como nos abrem caminhos para pensar como a gladiatura e sua organização envolvia distintas camadas sociais. A base da documentação para estudar tais redes é epigráfica, fonte preciosa para analisar diversos aspectos dos munera imperiais, privados e do próprio cotidiano dos gladiadores" (GARRAFFONI, 2005, p. 152). Ainda segundo a historiadora, "dentre as várias lápides que constituem seu catálogo, selecionamos duas, neste primeiro momento. Tratam-se de lápides dedicadas aos gladiadores. Ambas do século I d.C. e nos interessam por que dizem respeito à administração de objetos e roupas utilizados pelos gladiadores no momento do combate e, conseqüentemente, levam-nos a pensar sobre a importância que elas possuíam durante a realização das lutas e os efeitos simbólicos que poderiam causar entre aqueles que viam os espetáculos (p. 153).

${ }^{135}$ A música era freqüente na sociedade romana ainda que em eventos como os combates gladiatoriais, era um acessório. Segundo Valérie Péché e Ch. Vendries (2001), "a parte musical era limitada a um papel acessório sendo dado que os músicos só interviam em alguns momentos precisos de combates entre gladiadores. Em outros termos, não se ia ao anfiteatro para escutar música. Como explicar neste caso o grande número de imagens que mostram músicos em ação por ocasião dos munera? Sem dúvida, em parte, porque esta imagética era bem popular no Império: se o músico não aparecesse como o personagem chave do espetáculo, como o tibicen no teatro, era assim mesmo percebido como um auxiliar indispensável para o desenrolar deste último" (p. 75). O próprio Sêneca faz inúmeras referências à música, a condição dos músicos e aos concursos (Epist. Mor. 08, 8-9, 76, 4 e 84, 10; Tranquilitate Animae II, 8, II, 13). 
refrear os desejos (Epist. Mor. 88, 3/4); a geometria, por sua vez, ensina o manejo com os números, mas não impede à avareza (Epist. Mor. 88, 10); a matemática, segundo Sêneca, "se através dela fosse capaz de compreender a natureza do mundo, eu diria que seria ela de grande utilidade para nosso espírito humano, o qual se eleva pelo estudo celeste e como que recebe em si algo do céu" (si totius mundi naturam posset comprehendere, dicerem multum collaturam mentibus nostris, quae tractatu coelestium crescunt trahuntque aliquid ex alto) (Epist. Mor. 88, 28) e, finalmente, a música ensina harmonizar os sons agudos e graves, mas deveria, antes de tudo, harmonizar o espírito consigo mesmo, ter consonância nas idéias (Epist. Mor. 88, 9).

As artes liberais, na prática, podem ser exercidas por escravos, libertos e ingenui, independe da condição jurídica. Dependem sim de um fator essencial, ou seja, a capacidade de não negar a importância do trabalho, é um fator de sobrevivência do agente. Deve haver um grande número de indivíduos que se dedicam a ofícios como o de gramático, médico e piloto. Em razão disto, Sêneca afirma que os bens destas atividades são acessíveis até mesmo aos homens humildes. De acordo com suas palavras,

Nas atividades de gramático, de médico ou de piloto vemos os respectivos bens serem acessíveis a homens extremamente humildes. Só que tais profissões não têm por finalidade a grandeza de alma, não implicam elevação moral, não são hostis aos favores do acaso ( $N a m$ et in grammatica, et in arte medendi, aut gubernandi, videmus humillimis quibusque bona contingere - Sed istae artes non sunt magnitudinem animi professae, non consurgunt in altum, nec fortuita fastidiunt) (Epist. Mor. 87, 15).

Essa afirmação é essencial por revelar três questões: primeiro, o cotidiano do homem popular não é marcado pela desocupação ou ociosidade, muito pelo contrário, trabalha e se sustenta; em segundo, podemos supor que há uma especialização e preparo desses agentes para o exercício destes ofícios e, por fim, há uma demanda social, levando-se em consideração que 
todos teriam acesso aos serviços, mesmo aqueles homens, a quem tudo falta (De Clem. Pr. I, 3). O gramático é um bom exemplo: a leitura e a escrita fazem parte do cotidiano de qualquer homem, mesmo que Sêneca não nos apresente informações mais específicas, se compararmos com outros documentos (e.g. pinturas vesuvianas, epigrafia, numismática e grafites) ${ }^{136}$, veremos a escrita como suporte imprescindível à sociedade romana, independia da posição do agente na estrutura social. É evidente, dentro de contextos específicos, a utilização e o objetivo da escrita diversificar-se-ia entre indivíduos ou grupos sociais, mas, de modo geral, é corriqueira e necessária sua existência no mundo romano.

As artes manuais são semelhantes às liberais, pelo menos, no que diz respeito à obtenção da virtude. Ambas não possuem pré-requisitos para melhorarem o espírito, evitar os excessos, moderar as paixões. Aos olhos do pensador,

Um operário não precisa investigar qual a origem ou a utilidade do seu trabalho, tal como o bailarino o não tem que fazer quanto à arte da dança: os conhecimentos relativos a todas estas artes estão circunscritos a elas mesmas, porquanto elas não têm incidência sobre a totalidade da vida. $A$ virtude, porém, implica tanto o conhecimento dela própria como o de tudo o mais (Non est necesse fabro de fabrica quaerere, quod ejus initium, quis usus sit; non magis quam pantomimo, de arte saltandi. Omnes istae artes se sciunt, nihil deest; non enim ad totam pertinent vitam. Virtus et aliorum scientia est, et sui) (Epist. Mor. 95, 56).

\footnotetext{
136 Temos inúmeros exemplos de estudos sobre a sociedade romana que utilizam como fonte documental: textos escritos em túmulos, paredes, ânforas entre outros. O que demonstra a importância da escrita em todos os setores sociais. O historiador Funari, especialista em grafites, estudou as inscrições que continham expressões populares em seus vários aspectos: política, amor, sexualidade $(1989 ; 2001)$ etc. Um outro estudo, citado anteriormente, realizado pela historiadora Garraffoni (2005) sobre os gladiadores utilizou, de forma abundante, inscrições que abarcavam a vida cotidiana destes agentes. São elas: grafites com imagens e grafites com escritas (p. 203), inscrições tumulares (pp. 210-12); além de fontes escritas como Artemidoro, Augusto, Juvenal, Marcial, Plínio, Sêneca, Suetônio entre outros (p. 213). Isto mostra como afirmou Regina Bustamante (2006), que a Epigrafia "é uma das principais fontes da História Romana, sobretudo para o período do Império, pois relaciona documentos oficiais, que se pode datar com precisão, e permite estudos onomásticos (relativos a nomes) e prosopográficos (relativos a vidas). Numerosas abreviações, que elas comportam, encontramse em manuais de Epigrafia" (p. 109). Consultar texto sobre a importância das fontes materiais: FUNARI, P. P. A. Fontes arqueológicas - os historiadores e a cultura material. In: PINSKY, Carla Bassanezi (Org.). Fontes Históricas. São Paulo: Contexto, 2006, pp. 81-110.
} 
A diferença encontra-se no fato de que as artes manuais são "reconhecidamente inferiores". O que indica, segundo a leitura senequiana, haver uma hierarquização entre ofícios. Se assim não fosse, o filósofo não consideraria as atividades manuais inferiores. De acordo com as palavras de Sêneca,

o sábio, ao contrário do que pensa Possidônio, não passou a rejeitar as artes manuais, pela boa razão de que nunca as praticou. O sábio, de fato, nunca julgaria que merecia a pena inventar qualquer coisa que, em seu entender, não fosse para usar para sempre (Non abduxit, inquam, se, ut Posidônio videtur, ab istis artibus sapiens, seda d illas omnino non venit. Nihil enim dignum inventu judicasset, quod non erat dignum perpetuo usu judicaturus) (Epist. Mor. 90, 30)

O indivíduo que se dedica às artes manuais não poderia alcançar o bem, pois sua matéria é indivisível (De Prouidentia V, 9), o conhecimento é restrito em sua própria atividade e é impensável inventar algo que não tivesse utilidade para o futuro. Quais são elas? Pictor, oris, Statualis, is e Marmorarius, a, um (Epist. Mor. 88, 18, 27-28), consideradas por Sêneca, como tipos diferenciados de artesãos, que podem ser, igualmente, associados as grandes construções (Epist. Mor. 56, 4) ${ }^{137}$. Um exemplo disto aparece no momento em que Sêneca em um diálogo imaginário com Lucílio discute a posição de Possidônio sobre o surgimento da técnica como responsabilidade da filosofia. Sêneca, contrariamente, propõe, como afirmamos anteriormente, que o risco dessas habitações em que a técnica edifica casas umas em cima das outras são responsabilidades do cultivo da avareza e não da filosofia (Epist. Mor. 90 7/8). Aos olhos do filósofo, as habitações que colocam em risco à vida humana

${ }^{137}$ Estas atividades eram associadas igualmente às grandes construções, como sugeriu o P. A. Brunt (1968), havia "proventos casuais, auferidos especialmente no negócio de construções, em que as operações não eram suficientemente contínuas para garantir a utilização de escravos, que tinham que ser alimentados e vestidos, estivessem ou não trabalhando. $O$ imperador Vespasiano era um ativo construtor. Certa vez, quando um engenheiro foi à sua presença e ofereceu-lhe um instrumento capaz de poupar-lhe mão-de-obra, Vespasiano o recompensou, mas negou-se a usar o aparelho: "Você deve deixar-me alimentar meus próprios súditos, disse ele" (p. 172). 
surgiram com os arquitetos e estucadores, responsáveis pelo corte rigoroso das madeiras que desencadeiam o luxo (Epist. Mor. 90, 9). Em uma época anterior, Sêneca afirma que os

simples barrotes, fixos em ambos os lados, escoravam as habitações; um telhado feito de ramos e folhagens, disposto obliquamente, permitia 0 escoamento até das maiores chuvas. Em casa deste tipo, os homens viviam em segurança; sob um teto de colmo habitavam homens livres, entre paredes de mármore e ouro vive hoje a servidão (spissatis ramalibus, ac fronde congesta et in proclive disposita, decursus imbribus, quamvis magnis, erat. Sub his tectis habitavere securi. Culmus liberos texi; sub marmore atque auro servitus habitat) (Epist. Mor. 90, 10).

O filósofo embora utilize uma abordagem moral, para enfatizar o risco dessas residências e suas conseqüências decorrentes do excesso pelo luxo e o desejo pelo lucro (Epist. Mor. 90, 13) ${ }^{138}$, discute o problema de forma indireta. Vejamos o porquê. Esta referência a casas construídas por andares eram aquelas designadas por insulae, cuja preocupação do arquiteto baseia-se apenas na altura elevada, dessa forma, aumentariam os números de inquilinos. Construídas sem solidez, pois nos últimos andares das paredes eram feitas com barro amassado e a madeira dos vigamentos, em um menor abatimento, provocava desmoronamentos como também incêndios. Muito recorrente, destruíam rapidamente bairros inteiros.

Foi o que aconteceu em 64 d.C., o fogo destruiu um terço da cidade. O número de desabrigados instigaram empreendedores que se comprometiam a construir novas insulae, igualmente, frágeis e vulneráveis. O objetivo primordial é o lucro obtido com o aluguel e quanto mais propriedade, maior a

\footnotetext{
${ }^{138}$ O significado de lucrus, $i$ representava ganho, proveito, ganância, riqueza e vantagem (cf. SARAIVA, 1993, p. 691), e Sêneca utiliza-o especialmente no sentido de riqueza e ganância. Como sugeriu Andréa Giardina (1991), o signo do lucrum se distancia mais das visões das classes altas. "Para exprimir o lucro, os Gregos utilizavam uma palavra, kerdos, que ocupa um lugar fundamental no léxico da metis, a inteligência humana. Mas kerdos é também truque, o estratagema inesperado que coloca o indivíduo numa situação de vantagem, e Kerdo é o nome do mais astuto dos animais, a raposa. O mercador, que tem em mira o lucro obtido por meio da astúcia, é o homem de metis. O termo repete-se no vocabulário da sátira romana para designar o sórdido ofício do artesão e do pequeno comerciante" (p. 220).
} 
renda. Não há uma preocupação em construir casas seguras. O interesse é alugar a um locatório principal que, por sua vez, subaluga o apartamento tendo um lucro substancial. O reflexo disto é apresentado por Sêneca na seguinte crítica: "os homens recebem pensões e aluguéis com muito prazer e concentram neles suas preocupações, esforços e cuidados, mas ninguém dá valor ao tempo" (Annua, congiaria homines carissime accipiunt et illis aut laborem aut operam aut diligentiam suam locant: nemo aestimat tempus) (Ad Paulinum de Brevitate Vitae VIII, 2).

A partir dessa abordagem moral, Sêneca faz um levantamento do problema: a péssima qualidade das construções, associada à lucratividade e aos constantes desmoronamentos e incêndios coloca em risco a vida das pessoas, assim como as construções geram a possibilidade de captação de capital e, conseqüentemente, a aplicação destes recursos em propriedades rurais e em outras atividades comerciais. A historiografia contemporânea, no entanto, se deixa influenciar pelos preconceitos dos antigos e ignora a maneira pela qual é obtida a fortuna que permite a compra dessas propriedades (MOREL, 1991, p. 192) ${ }^{139}$.

Nossa fonte primária, por um lado, não fornece indicações numéricas se o artesanato (assim como outra atividade, comercial ou não) fosse fonte considerável de riqueza para que se pudesse adquirir uma propriedade rural. Por outro lado, constrói o universo das artes liberal, manual e prazerosa pela associação, em essência, com o lucro. Os contemporâneos

\footnotetext{
139 Isto ocorria, segundo Morel: "não só porque se julga que a posse de terras proporciona lucros mais seguros do que a atividade artesanal, o que é nitidamente errado se considerar o caráter aleatório da agricultura (...) mas, e, sobretudo, porque a indústria é concebida pela maior parte dos historiadores atuais da economia antiga como "uma atividade anexa da agricultura", ou como "um ramo da agricultura", o artesão teria gravitado em torno da agricultura como um satélite menor da vida econômica romana" (p. 192).
} 
de Sêneca, de acordo com sua opinião, não privilegiam o crescimento espiritual e sim a obtenção de vantagens, por isso, não admira, nem incluía entre os bens autênticos um estudo que adjetivasse o lucro. Seriam úteis apenas na preparação do intelecto, não deveria ser a única ocupação do indivíduo (Epist. Mor. 88, 1). Pode-se supor em primeira instância a possibilidade não apenas dos setores subalternos, mas igualmente aristocratas exercerem atividades lucrativas que não estivessem ligadas à agricultura ${ }^{140}$.

Um exemplo desse caso seria o mercator, considerado uma arte

ligada ao prazer, o filósofo o associa ao lucro. De acordo com suas palavras,

uma avareza insaciável apossa-se de um, de outro, uma laboriosa dedicação a atividades inúteis, um embriaga-se de vinho, outro entorpecese na inatividade; a este, uma ambição sempre dependente das opiniões alheias o esgota, um incontido desejo de comerciar leva aquele a percorrer todas as terras e todos os mares, na esperança de lucro (Alium insatiabilis tenet auaritia; alium in superuacuis laboritus operosa sedulitas; alius uino madet, alius inertia torpet; alium mercandi praeceps cupiditas circa omnis terras, omnia maria spe lucri ducit) (Ad Paulinum de Brevitate Vitae II, 1).

Esta referência à "esperança por lucro" é uma forma de aferir sobre a competitividade do ofício que conduz o mercator a obter lucro inesperado, aproveitar a oportunidade favorável e a habilidade de previsão ${ }^{141}$. Em função disto, Sêneca faz o seguinte questionamento:

Imagina que Netuno proporcionou uma travessia marítima a mais completa calmaria: não é verdade que, em idênticas circunstâncias, um homem cujo navio transportava uma carga maior e mais preciosa se mostrará mais grato para com o deus? Não é verdade que o mercador pagará mais pressurosamente a promessa feita do que o simples passageiro? Não é

\footnotetext{
${ }^{140}$ Consultar Gian Mario Cazzanga (1984). Cazzanga discute a controvérsia entre primitivistas e modernistas opondo quem analisava a economia antiga em termos de sociedade agropastoral e de autoconsumo, substancialmente privada de circulação monetária, e quem pelo contrário tinha de lhes impor características capitalistas sublinhando o rol da economia monetária e financeira, a produção para o mercado interno e para exportação. Trata-se de orientações que, se partem corretamente da refutação da equação "atividade comercial = sistema de mercado capitalista", acaba por viciar toda polêmica inicial entre primitivistas e modernistas, terminando pois por não saírem de um círculo vicioso tanto quanto, negando a possibilidade de ler o mundo antigo através de categorias da economia de mercado, negando por fim a possibilidade de uma análise do mundo antigo (cf. p. 144).

${ }^{141}$ Segundo Giardina (1991), o sentido de previsão do mercador "permitia conhecer antes dos outros a mudança das situações, a superabundância ou a escassez das mercadorias, as boas colheitas e as carestias" (p. 209).
} 
verdade que, mesmo entre os mercadores, se lhe mostrará muito mais grato àquele que transportava perfumes, púrpuras e outros bens pagáveis a peso de ouro do que um outro cuja carga quase nada valia e quase só servia para lastro (Sed quemadmodum Neptuno plus debere se judicat, ex his qui eadem tranquilitate usi sunt, qui plura et pretiosiora illo mari vexit; et animosius a mercatore, quam a vectore, solvitur votum; et ex ipsis mercatoribus effusius gratus est, qui odores ac purpuras, et auro pensanda portabat, quam qui vilissima quaeque, et saburrae loco futura, congesserat) (Epist. Mor. 73, 5).

Pode-se supor que há uma busca por mercadorias mais competitivas fundamentada na lei da oferta e procura. O retrato disto é apresentado pelo filósofo, da mesma forma, no momento em que se questiona acerca das oficinas de teares (Epist. Mor. 90, 20) O filósofo associa a tecelagem ${ }^{142}$ à inutilidade por produzir, muito provavelmente, tecidos de luxo, apreciados por setores específicos da sociedade romana, ou seja, aristocratas ou agentes sem status social, mas com capital (dinheiro, propriedades e negócios).

Os ofícios de mercador e de tecelagem, classificados pelo filósofo pela categoria de prazer são associados ao lucro, promiscuidade, riqueza e

${ }^{142}$ Ainda que Sêneca comente apenas de forma superficial sobre a tecelagem vinculada ao luxo, sabemos, por outras fontes documentais (e.g. Apuleio em o Asno de Ouro), que as tecelãs pobres tinham uma importante participação ativa no núcleo econômico. Daí a prática matrimonial nas camadas miseráveis retratar um esquema de sobrevivência. Se pensarmos que o povo "vivia amontoado em cubículos exíguos e as famílias populares, na maior parte dos casos, não tinham nem acesso a banheiro e cozinha próprios" (FUNARI, 1998, p. 30). De fato, a mulher e os filhos, possuíam uma participação ativa no núcleo econômico, por exemplo, a "esposa do jornaleiro" o humilha dizendo que ele não era capaz de trazer nem o azeite, símbolo de miséria (APULEIO, O asno de Ouro IX, V). Mesmo obtendo um lucro ínfimo a personagem apuleiana conseguia manter com a tecelagem rústica (lembremos que Sêneca referia-se à obtenção de lucro, através de mercadorias 'pagas a peso de ouro' (Epist. Mor. 73, 5)), o mínimo para a manutenção de sua casa: a luz. Além de serem fiandeiras, exerciam funções de parteiras, amas, estalajadeiras. Tais trabalhos, muitas vezes, foram de suma importância como era o caso das parteiras. Estas possibilitaram aos médicos um conhecimento anatômico do corpo feminino, pois "foram às mulheres que - com uma atenção muito sutil observaram seus próprios corpos. Algumas delas adquiriram qualificações e foram de certo modo as especialistas do bairro, da aldeia, da casa (...) São parteiras que cuidam de todas as doenças das mulheres; foram elas que informaram os médicos antigos, aqueles de quem lemos os escritos" (RousselLE, 1983, p. 38).

Não seria absurdo, portanto, supor que "as mulheres das classes subalternas inferiores eram mais emancipadas, mais iguais, se não de direito, pelo menos de fato, e mais, amplamente aceitas como indivíduos (...) que suas irmãs aristocráticas (...) Some-se a isso a necessidade econômica, as más condições de moradia e o fato de trabalharem para viver e não para matar o tempo" (FUNARI, 1998, p. 39). Consultar obra de Feitosa por discutir a atuação da mulher em ambientes populares da cidade de Pompéia. FEITOSA, Amor e sexualidade: 0 masculino e o feminino em grafites de Pompéia, 2005. 
luxo. Tais atividades são tratadas com desprezo pelo fato de serem ofícios que desencadeiam, de acordo com a filosofia da stoa, o excesso pelo luxo, pelo vinho, pela comida, pela vestimenta, o cuidado com a beleza, o gosto por animais exóticos que gera o comércio realizado por longas distâncias. Com isso, segundo a leitura senequiana, desperta nos homens a ambição pelo lucro. Um exemplo disso refere-se à condenação de Sêneca às importações do oriente com produtos destinados à mesa. Citemos in extenso:

Querem que se apanhe para além do Fasis aquilo com que forneçam sua requintada cozinha, nem se envergonham de pedir aves aos partos, dos quais ainda não nos vingamos. De todas as partes transportam todos os alimentos conhecidos de sua gula enfastiada; e trazem dos confins do oceano aquilo que seu estômago, desgastados pelos prazeres, com dificuldade pode aceitar. Vomitam para comer, comem para vomitar, e não se dignam a digerir as iguarias que buscam por toda a terra (VItra Phasin capi uolunt quod ambitiosam popinam instruat, nec piget a Parthis, a quibus nondum poenas repetiimus, aues petere. Vndique conuehunt omnia nota fastidienti gulae; quod dissolutus deliciis stomachus uix admittat ab ultimo portatur Oceano. Vomunt ut edant, edunt ut uomant, et epulas, quas toto orbe conquirunt, nec concoquere dignantur) (Ad Helviam de Consolatione $\mathrm{X}, 03)^{143}$.

Além dessas atividades lucrativas, Sêneca refletia sobre outros ofícios destinados igualmente aos prazeres, mas considerados como sendo os mais vis e, muito provavelmente, bem menos lucrativos, se comparados ao comércio de bens luxuosos e a tecelagem de tecidos finos. São elas: meretrix (De Prouidentia V, 3), gladiator (Ep. Mor. 37, 2), fornicor (De Prouidentia V,

143 Como sugeriu Giacchero (1980), aqui "a condenação moral se coloca em um plano secundário com relação à preocupação política e financeira de troca comercial com povos hostis e belicosos (...) Os mercadores, que conseguiam produtos gastronômicos exóticos, pagavam os estrangeiros e os inimigos partos em espécie, com aurei e com denarii, insistindo em alimentar aquele êxodo de pecuniae nostrae ad externas aut hostilis gentes, que Tibério tinha estigmatizado (...) As relações com os romanos eram completamente positivas para os partos, não somente no resultado econômico, tanto quanto favorecia o conhecimento dos ordenamentos militares, da tática estratégica e da estrutura política do império inimigo. Como intermediários do comércio indiano e chinês para o Mediterrâneo ou como exportadores dos produtos locais, os partos conseguiram a partir da relação com o Ocidente uma capacidade reforçada de resistência e de ofensiva para com o estado romano" (p. 1105). 
2), alipius (Ep. Mor. 56, 12), Botularius e Crustularius (Epist. Mor. 56, 12) ${ }^{144}$

e Atheta (Epist. Mor. 88, 18).

Como podemos observar os ofícios de prostituto (a), cafetão, gladiador, depilador, cozinheiro e vendedores (salsichas, pásteis e bebidas) são também relacionáveis à promiscuidade e riqueza, assim como à brutalidade. São ofícios indignos, em geral, por se dedicarem aos prazeres sensuais e ao vinho. Aos olhos de Sêneca não há ocupação mais vergonhosa (Ad Paulinum de Brevitate Vitae VII, 1). As meretrizes são chamadas por "cadelas promíscuas" (De Prouidentia V, 3), o proxeneta, considerado um ser infame, responsável pela intermediação das relações entre clientes e prostituta(o)s (Epist. Mor. 87, 14/15), o lanista, responsável pela negociação de gladiadores, os atletas vistos pela debilidade mental que são admirados, segundo Sêneca, por seus contemporâneos (Epist. Mor. 80, 2) e o gladiador, um personagem construído por imagens variadas. Mas, de maneira geral, depreciado por serem homens, que em alguns casos alugam seus braços na arena (Epist. Mor. 37,2) ${ }^{145}$. O que indica que em algumas situações poderíamos encontrar gladiadores de aluguéis e, não necessariamente apenas como pontua a historiografia tradicional, por escravos ou indivíduos condenados à morte na arena ${ }^{146}$.

\footnotetext{
${ }^{144}$ Os termos seguintes significam: alipilus, $i$ (depilador), fornicor, aris, atus, sum, ari (cafetão) Botularius, ii (vendedor de salsichas) e Crustularius, ii (pasteleiro).

${ }^{145}$ Sêneca ainda que reprove os jogos gladiatoriais não deixou de evocar a paixão do populus, aparecendo sob um tema geral o "combate". Utilizou metáforas sobre a condição humana: Epist Mor. 30, 8; 37,2; 92, 26; 93, 12, Tranquilitate Animae 11, 4/5 e De Ira III, 43); a luta contra os maus exteriores, as adversidades da fortuna: Prouidentia 2, 7/8; Epist. Mor. 64, 4; 117, 25; De Const. Sapientis 16, 1; as dificuldades da vida social, utilizando o simbolismo da gladiatura: De Ira 34, 5, 6; I, II, 1; III, 42, 3; De Clem. I, 7, 4; Epist. Mor. 14, 15); a vida moral: Epist. Mor. 37, 1/2; 104, 34; 117, 25 ou De Beneficiis V, 3,3; V, 4, 1 em que a imagem dos gladiadores eram de emulação dos benefícios. Consultar MARCHETTI, Mireille Armisen. Sapientiae facies: étude sur les images de Sénèque. Paris: Les Belles Lettres, 1989.

${ }^{146} \mathrm{~A}$ respeito da historiografia sobre os jogos gladiatoriais e a figura do gladiador, propriamente dito, consultar a obra já citada de Garraffoni (2005).
} 
Como podemos perceber o universo romano não é apenas conformado pela idéia idílica de ociosidade, e sim uma sociedade em que os homens laboram por diversos motivos, sejam por sobrevivência ou lucro, não vivem amotinados em espetáculos à espera de doações. Sêneca relata que a prosperidade recaia até mesmo sobre a plebs e os talentos medíocres (prosperae res et in plebem ac uilia ingenia deueniunt) (De Prouidentia IV, 1). Para Sêneca, como para nós, é um grupo socioeconômico ativo que luta por sua sobrevivência e cria alternativas próprias de vida social.

Assim é o cafetão Élio, retratado em uma das elucubrações que Sêneca redige sobre a riqueza. De acordo com suas palavras, "as riquezas não são um bem; por isso, que os tenha o cafetão Élio, para que os homens vejam o dinheiro, que é consagrado nos templos, lá no prostíbulo" (Non sunt diuitae bonum; itaque habeat illas et Elius leno, ut homines pecuniam, cum in templis consecrauerint, uideant et in fornice) (De Prouidentia V, 2). Embora considere a existência do cafetão repugnante, Sêneca o nomeia; fato de extrema relevância, levando-se em consideração o tratamento pelo anonimato dado aos setores subalternos. Além disso, Élio se mantinha por si próprio e possuía riqueza proveniente da prostituição. Em outra obra, Sêneca afirma que a riqueza está ao alcance do proxeneta e do lanista. Por isso, a riqueza não é um bem em si (Epist. Mor. 87, 15/15). Isto indica, sobretudo, não apenas um juízo de valor, mas ofícios rentáveis, pelo menos do ponto de vista econômico.

Sêneca menciona desde os vendedores de salsichas nos balneários, ou pequenos comerciantes até o comércio de iguarias suntuosas destinadas à aristocracia romana. Podemos afirmar que os setores subalternos exerciam ofícios como artesanato, comércio, cabeleireiro, porteiro, taberneiros, entre 
outros, desenvolvidos por libertos, cidadãos ricos ou pobres e escravos. Mas não são atividades consideradas, por Sêneca, honrosas, pois não torna possível, como o estudo da filosofia, o engrandecimento da alma pela virtude (Ad Paulinum de Brevitate Vitae, De Constantia Sapientis, De Prouidentia, Epistulae Morales).

Nas Epistulae Morales, Sêneca, por viver sob uma terma, reclama dos ruídos e dos gritos de banhistas, vendedores e também dos barulhos das carroças, dos músicos e de um carpinteiro (Epist. Mor. 56, 1/5) ${ }^{147}$. Retrata também a venda de alimentos, dizendo: "além disso, as diferentes exclamações do pasteleiro, do salsicheiro, do vendedor de bebidas e todos os negociantes de tabernas, cada um, apregoando sua mercadoria com uma entoação própria" (Jam libarii varias exclamationes, et botularium, et crustularium, et omnes popinarum institores, mercem sua quadam et insignita modulatione vendentes) (Epist. Mor. 56, 2).

Isso indica por si próprio e através de Sêneca, que há um intenso comércio, grupos de artesãos e lojistas ocupam a urbs, causando desconforto para as autoridades e os aristocratas que viviam nas proximidades; o que indica que o artesão romano é um homem da cidade. A falta de espaços, a poluição, os ruídos, os cheiros, os riscos de incêndios e a incompatibilidade de adequar o ideal de prestígio aos centros urbanos faz com que Sêneca não recomendasse viver rodeado de carrascos e de tabernas (Epist. Mor. 51, 4) ${ }^{148}$.

\footnotetext{
147 As termas são locais financiados pelos membros aristocráticos de sociedade romana. Sêneca, nesse sentido, desenha o seguinte quadro: "Sim, os mais nobres desempenhavam outrora a função de entrar nesses lugares freqüentados pela multidão, de assegurar a sua temperatura adequada à saúde, e não este calor que hoje está na moda e mais parece calor de incêndio" (Nam hoc quoque nobilissimi aedilis fungebantur officio, intrandi ea loca, quae populum receptabant, exigendique munditias, et utilem ac salubrem temperaturam; non hanc, quae nuper inventa est, similis incendio) (Epist. Mor. 86, 10).

${ }^{148}$ Esse espaço de instabilidade, causado pela falta de segurança levam imperadores e edis, como sugere Jean-Paul Morel (1991), a impedir que as lojas invadam a cidade, ou pelo menos,
} 
A venda de alimentos demonstra duas coisas: os agentes

subalternos trabalham e se alimentam de seu pecúlio. Temos, nestes ofícios,

não um desprezo e sim um retrato de como os setores subalternos vivem em

confina-las a certos bairros. Ainda segundo o autor, "a incerteza da situação do artesão, a sensação de precariedade que o invade, dependem também do fato de ele ser um elemento de perturbação, tanto mais que a natureza da sua atividade o leva a fixar-se no centro das cidades, onde a multidão é mais densa e as possibilidades de encontrar clientes são maiores, coisa que nem sempre é bem vista" (p. 198). Trata-se, como afirma Morel, "de uma tendência generalizada, pois no centro de uma cidade de pequenas dimensões como Alésia, proliferam as oficinas metalúrgicas" (ibidem). Todavia, nos grandes centros urbanos, como a cidade de Roma, está preocupação atingia governantes, administradores e pensadores como Sêneca por sugerirem um certo "descontrole" ou "indisciplina" destas atividades (ibidem).

Essa inquietação em relação à urbanização é, ainda hoje, uma questão amplamente debatida pela sociedade e instituições políticas. Discutem melhores formas de concentrar o comércio popular em determinadas regiões, enquanto, o comércio e a residência de cidadãos "privilegiados economicamente" são localizados em ambientes como shopping e condomínio residencial. Isto representa uma forma de afastar e controlar as desigualdades sociais no mundo contemporâneo, que não é, de forma alguma, uma tarefa simplista: à carência de recursos, gerada pela má distribuição de renda, provoca violência e crescimento de trabalho informal. A desigualdade social não respeita espaços ou barreiras.

Cabe lembrarmos que os pregões retratados por Sêneca se assemelham à condição do trabalhador brasileiro. Este vive na informalidade, sem registro na carteira de trabalho, em ambientes como terminais rodoviários e centros das grandes cidades (e.g. São Paulo têm ruas famosas como 25 de Março, Largo Treze de Maio em Santo Amaro, Estação do Brás, especialmente, avenida Rangel Pestana, praça da Sé e trens urbanos que abrigam uma infinidade de comerciantes ambulantes) vendendo todos os tipos de produtos, desde os alimentos perecíveis aos não perecíveis, como roupas, brinquedos e todo o tipo de pirataria como produtos de informática, cds e dvds.

Como sabemos, a informalidade gera alguns problemas de cunho econômico e social, tais como: conflitos entre lojistas e ambulantes que competem para atrair mais clientes, tendo em vista, uma problemática central: o lojista tem uma carga altíssima de impostos que eleva o preço final dos produtos, enquanto, o ambulante, livre de impostos, pode abaixar o valor das mercadorias, atraindo, dessa forma, mais compradores. Conduz, igualmente, o trabalhador a viver sem a segurança da previdência social (a não ser que pague como autônomo), não têm direitos de receber férias, décimo terceiro do salário, seguro desemprego e em caso de acidente de trabalho, não pode ser aposentado por invalidez ou continuar recebendo até que esteja apto a retornar as atividades e a aposentadoria. Esta situação deve-se a fatores como a desestruturação da educação, responsável pela qualificação dos agentes que é exigido no mercado de trabalho. Como sugeriu o economista Tafner, "somos um fracasso no sistema educacional, que é o elemento que qualifica o trabalho" (TAFNER Apud CASTRo, 2006).

O resultado disso é um crescimento da informalidade no Brasil. Segundo as autoras Sá e Araújo, do jornal $O$ Globo, São Paulo registrou o menor índice entre mulheres (chefes) de família, 27\%. Em outras regiões metropolitanas do país, no entanto, os índices de informalidade aumentaram como Salvador, com $34,2 \%$, Rio de Janeiro, com $33,6 \%$, seguida de Recife, com 33,2\%, Belo Horizonte, com 28,4\% e Porto Alegre, com 27,2\%. As autoras apresentam um depoimento da empregada doméstica Diná de Jesus Santos, 36 anos, separada e mora com seus três filhos no bairro de Cajazeiras, periferia de Salvador. Trabalha com carteira assinada e recebe $R \$ 300,00$ por mês, mas diz que se recebesse uma proposta melhor, trabalharia sem registro (SA \& ARAUJO, 2006). Temos, portanto, duas situações marcantes: dados alarmantes dos níveis de informalidade e indivíduos com registros, mas com salários baixíssimos, forçando-os, mais uma vez, à informalidade. Estas situações, tomando às devidas proporções históricas, não se diferenciam em demasia da realidade romana. Consultar anexo II: Fonte Mensal de Emprego - PME. Fonte: IBGE - Instituto Brasileiro de Geografia e Estatística. 
seu cotidiano, mantendo-se de atividades rendosas e não apenas sobrevivendo de pão e divertimento. Visão estereotipada e construída ao longo da História.

Muitos romanos, assim como Sêneca, veem os trabalhadores como seres grosseiros e ignóbeis, indignos de serem vistos como cidadãos. Consideram a posse de propriedades fundiárias o único meio que se pode conquistar uma posição social. Esta imagem do trabalhador pela falta de dignidade e de beleza, sendo, portanto, considerados pobres e viciosos (Epist. Mor. 88,10$)$ pelo fato de serem obrigados a se dedicarem às atividades remuneradas, ainda que alguns deles não fossem de condição servil, não dispunham de seu próprio tempo, e, portanto, não podem negar a importância do trabalho. A fonte senequiana apresentou, além de preconceitos, inúmeras atividades remuneradas, todas elas com suas especialidades e hierarquias, realizadas pelos homens da plebe ricos ou pobres, escravos e libertos. É impensável imaginá-los como setores sociais omissos, preocupados apenas com o seu pão e divertimento, vivendo de forma ociosa, dependentes das distribuições de trigo. 


\section{Conclusão}

"Podemos, dessa maneira, distinguir dois tipos de busca da verdade. O primeiro é o que nasce da decepção, da incerteza e da insegurança e, por si mesmo, exige que saímos de tal situação readquirindo certezas. O segundo é o que nasce da deliberação ou decisão de não aceitar as certezas e crenças estabelecidas, de ir além delas e de encontrar explicações, interpretações e significados para a realidade que nos cerca".

Marilena Chauí Ignorância e Verdade, 1998. 
Nossa pesquisa, desenvolvida a partir de 2003, centrou-se na análise dos setores subalternos da sociedade romana por algumas razões. Podemos afirmar, em primeira instância, acerca de inquietações e dúvidas. Esta, como sugeriu Marilena Chauí (1998), "nos fazem querer saber o que não sabíamos, nos fazem querer sair do estado de insegurança ou encantamento, nos fazem perceber nossa ignorância e criam o desejo de superar a incerteza" (p. 90). Ouvimos, desde criança, a fabricação de um imaginário social romano deturpado pela indústria cinematográfica, livros didáticos, ensino religioso (aqui incluímos as diversas vertentes religiosas, citaremos apenas duas: Igreja Católica Apostólica Romana e Adventista do Sétimo Dia) e, em alguns casos, pelas interpretações historiográficas que imprimem valores morais carregados de imagens pejorativas sobre violência, desinteresse pelo trabalho e passividade política da plebe, bastando às autoridades fornecer apenas o pão e o divertimento.

Há uma tendência das pessoas crerem nas informações recebidas de jornalistas, médicos, professores, cineastas, mentores espirituais que dizem a elas o que devem saber, o que podem saber, o que podem e devem fazer ou sentir, confiando na palavra desses 'emissores de mensagens', as pessoas se sentem seguras e confiantes, e não há incertezas porque há ignorância (CHAUI, 1998, p. 92).

Em vista disso, reconstroem imagens equivocadas dos setores populares da sociedade romana, delegando-os um papel secundário e elementar na História da Humanidade, fazendo crer em um continuum social, quer dizer, haveria sempre a constituição de um setor privilegiado dominando um outro, apático e manobrável. Esta reconstrução histórica é associada às situações de descrença na política brasileira. O cidadão decepcionado com a atitude de políticos ao ouvir programas com propostas, projetos e enfim, dando- 
Ihe o voto e depois, ludibriados, não só porque não são cumpridas as promessas, mas pelo estado de corrupção, o crescimento das desigualdades, miséria e violência, fazem críticas simplistas e equivocadas, não apenas do Império Romano, mas do Brasil, como um todo.

Decidimos, portanto, desconstruir duas idéias básicas: o mau uso do conceito panis et circenses como explicação da sociedade brasileira contemporânea e a interpretação historiográfica de que a plebe romana seria desinteressante e ociosa. Para tanto, apresentamos uma vertente historiográfica denominada tradicional por propor a política do pão e circo como parte predominante da estrutura social romana (cf. FRIEDLAENDER, 1947; GAGÉ, 1964; VeYNE, 1976; ROBERT, 1998, et alli).

Há uma outra corrente historiográfica que interpreta as relações sociais no império romano a partir das interações. A partir disto, propõe que a construção da sociedade seria pensada por aglomerados de grupos sociais ordenados, segundo critérios de concentração material e de prestígio social, hierarquizados como classe ou estamento que interagiam. Os agentes sociais pertencentes à elite eram capazes, fazendo uso da riqueza e do status, de manter e, ao mesmo tempo, submeter outros agentes sociais e interferir nas decisões do Estado.

Os laços sociais envolviam indivíduos de níveis sociais distintos. Haveria uma troca entre agentes mais próximos do centro do poder e entre aqueles mais afastados dele, cujo objetivo seria conseguir benefícios com as relações pessoais (WALLACE-HADRILL, 1990). Estas análises interacionais tendem, assim, a limitar a participação dos setores subalternos na estrutura social e na política do Império por dois motivos: primeiro por propor que os 
pobres não apareceriam, nem mesmo, em inscrições dedicadas às pessoas modestas (GARNSEY e SALLER, 1989); e em segundo supõem que os agentes subalternos conseguiriam alguma distinção, caso estivessem próximos do poder imperial, como escravo ou liberto imperial, exercendo atividades de funcionários e como mediadores do favor.

A emergência e a subordinação pessoal de ajuda se definiriam pelo acesso ou pela exclusão pelo fato de o poder ser derivado da proximidade com o imperador e sua habilidade de influenciar na distribuição de recursos (WAllace-HadRILL, 1996). Temos, dentro deste modelo interpretativo, a exclusão, quase na sua totalidade, de todos os agentes que não se adequavam a está situação de proximidade com os setores aristocráticos ou com a casa dourada, domus imperial.

Embasamos nossa crítica a historiografia contemporânea levando-se em consideração o corpus documental. Alguns tratados filosóficos e literários de Sêneca. Mesmo sendo um autor aristocrático e com idéias conservadoras em relação aos setores subalternos, muitas vezes, adjetivados de forma pejorativa (e.g. uulgus, multitudo), não deixou de registrar e discutir sua existência, com isso, percebemos a relevância destes setores na sociedade: não foram esquecidos, muito pelo contrário, aparecem em diversas situações do cotidiano.

Como ressaltamos no primeiro e terceiro capítulo, Sêneca não se restringiu apenas ao soberano e aos aristocratas, mas retratou comportamentos de indivíduos como barbeiros, gladiadores, escravos, depiladores entre outros. O que propiciava unidade a suas obras, pois descrevia a sociedade romana na sua totalidade, assim como enfatizava a 
honra, riqueza, favores, reputação, popularidade, estatuto jurídico, patrimônio como elementos geradores de prestígio social. Além disso, retratava relações de poder entre agentes inferiores e superiores: o poder de bajular, ou não um aristocrata, de apoiar, ou não, um imperador, de revoltar-se. Isto se devia ao fato de o poder ser uma prática e, portanto, se estabelecer por mecanismos em que todos os agentes sentem seus efeitos e relações, o poder não era (e continua assim na sociedade contemporânea) uma via de mão única. Um exemplo desta relação ocorria entre o senhor e o escravo. Aos olhos de Sêneca, os maus tratos do senhor geravam relações de inimizade e desconfiança com os escravos (Epist. Mor. 47, 5).

Além das relações pessoais que comandavam a rede de favores e redistribuições, i.e., as relações hierarquizadas entre superiores e inferiores ocorridas, em especial, na esfera privada; detectamos, igualmente, na narrativa senequiana elementos que nos conduziram a pressupor que havia identidade de grupo na esfera pública entre os setores subalternos como foi o caso da plebe. Sêneca construía a imagem de grupos distintos e heterogêneos que se reconheciam e se identificavam em determinados locais públicos, não importando as diferenças que se fundamentavam em termos de situação econômica, étnica e posição social. Sêneca retratava cada um dos grupos, fossem plebeus, libertos ou aristocratas que se reconheciam cada qual com seus atributos expressos na sociedade.

A proposição de que as camadas superiores se protegiam e se identificavam por pertencerem a uma organização corporativa, tendo assim, um controle de admissão e qualidade desses membros, mantendo-se, por conseqüência, a hierarquia e organização social, é um equívoco (ALFÖLDY, 
1989, p. 126). A homogeneidade da elite não representava um sistema fechado pelo simples fato de que toda categoria social formava-se pela pluralidade, inclusive a plebs romana. Esta perspectiva de que a homogeneidade garantiria uma maior estabilidade social e, portanto, um maior conhecimento sobre a estrutura social dos agentes é uma fábula. Sêneca apresentava uma visão muito mais complexa dos setores subalternos, do que aquela tradicional e assumida por boa parte da historiografia contemporânea, que se resume na pacificação, submissão e diversão.

Concluímos lembrando as palavras de Jean e Paulo Garfunkel (2006),

Quanto mais eu vivo Mais olho pro mundo, mais eu dou risada E no fundo da alma Me dá uma coceira engraçada $\mathrm{Ai}, \mathrm{Ai}$ !

Que acaba doendo. Dor de ver meu povo virando lata

(...) Na mão dos piratas $\mathrm{Ai}, \mathrm{Ai}$ !

E nem Deus tá vem 


\section{Bibliografia}

\section{Edições das obras de Sêneca}

\section{a. Edições em língua francesa:}

SÊNECA, L. A.. L'Apocoloquintose du divin Claude. Trad. par René Waltz. Paris: Les Belles Lettres, 1966.

. De la Clémence. Trad. par François Préchac. Paris: Les Belles Lettres, 1990.

. Lettres a Lucilius (Tome I). Trad. par MM. A.Grandsagne; Baillard, Charpentier, Cabaret-Dupaty ; Charles du Razoir; Héron de Villefosse ; Naudet, C. L. F. Panckoucke, E. Panckoucke; De Vatimesnil, A. De Wailly etc. Paris: Les Belles Lettres, 1833.

. Lettres a Lucilius (Tome VI/VII). Trad. par MM. A.Grandsagne; Baillard, Charpentier, Cabaret-Dupaty ; Charles du Razoir; Héron de Villefosse ; Naudet, C. L. F. Panckoucke, E. Panckoucke ; De Vatimesnil, A. De Wailly etc. Paris: Les Belles Lettres, 1834.

. Des Bienfaits (Tome I). Trad. par François Préchac. Paris: Le Belles Lettres, 1972.

. Consolations (Tome III). In: Dialogues. Trad. par René Waltz. Paris : Les Belles Lettres, 1923.

. De Ira (Tome I). In : Dialogues. Trad. par A. Bourgery. Paris: Les Belles Lettres, 1951.

- De la vie heureuse (Tome II). In: Dialogues. Trad. par A. Bourgery. Paris: Les Belles Lettres, 1955.

- De la brièveté de la vie. (Tome II). In: Dialogues. Trad. par A. Bourgery. Paris: Les Belles Lettres, 1955.

. De la Providence (Tome IV). Dialogues. Trad. René Waltz. Paris: Les Belles Lettres, 1950.

. De la Tranquillité de L'Ame (Tome IV). Dialogues. Trad. René Waltz. Paris: Les Belles Lettres, 1950.

. De l'oisiveté. Dialogues. Trad. René Waltz. Paris: Les Belles Lettres, 1950. 


\section{b. Edições em língua portuguesa:}

SÊNECA, L. A. Cartas a Lucílio. Tradução, Pref. e Notas de J. A. Segurado e Campos. Lisboa: Fundação Calouste Gulbenkian, 1991.

. A Vida Feliz. Tradução André Bartholomeu. Campinas: Pontes, 1991. . Sobre a firmeza do homem sábio. Tradução Ricardo da Cunha Lima. São Paulo: Nova Alexandria, 2000.

. Sobre a tranqüilidade da alma. Tradução José Rodrigues Seabra Filho. São Paulo: Nova Alexandria, 1994.

. Sobre o Ócio. Tradução de José Rodrigues Seabra Filho. São Paulo: Nova Alexandria, 1994.

- Consolação a Hélvia. In: Cartas Consolatórias. Tradução Cleonice Furtado Mendonça Van Raji. Campinas: Pontes, 1992.

. Sobre a Brevidade da Vida. Tradução de William Li. São Paulo: Nova Alexandria, 1993.

. Apocoloquintose do divino Cláudio. Tradução de Agostinho da Silva. São Paulo: Abril Cultural, 1980.

. Tratado sobre a Clemência. Tradução de Ingeborg Braren. Petrópolis: Vozes, 1990.

\section{Edições de outras obras clássicas}

APULEIO, Lucio. El Asno de Oro. Trad. Diego López de Cortegana. Madrid: Alianza, 1988.

ARISTÓTELES. A Política. Tradução de Nestor Silveira Chaves. Bauru: EDIPRO, 1995.

AVGVSTI, Divi. Res Gestae. Tradução de G. D. Leoni. São Paulo: Livraria Nobel, 1957.

SUÉTONE. Les douze Césars. Paris: Ambassade du Livre, 1963.

TACITE. Annales. Ed. et trad. P. Wuilleumier. Paris: Les Belles Lettres, 1975.

- Anais. Tradução J. L. FREIRE de Carvalho. Rio de Janeiro: W. M. Jackson Inc, 1952. 


\section{Literatura Contemporânea}

ALMEIDA, L. S. O significado político dos espetáculos oficiais na Roma Imperial. São Paulo: USP/FFLCH, 1994.

. Poder e política nos espetáculos em Roma. Clássica, São Paulo, v. 09/10, no 09/10, 1996/1997, pp. 132/141.

ALFÖLDY, GÉZA. História Social de Roma. Lisboa: Presença, 1989.

ANDRADE, Marta Mega de. Gênero, poder e diferenças. Phoînix, Rio de Janeiro, 11, 2005, pp. 171/187.

ANDRADE, Carlos Drummond. Mãos Dadas. In: Fazendeiro do ar e poesia até agora. Rio de Janeiro: Olympio, 1955, pp. 156.

. Diante das Fotos de Evandro Teixeira. In: Amar se aprende amando: poesia de convívio e de humor. Rio de Janeiro: Record, 1986, pp. 63/64.

ANDRÉ, JEAN-MARIE. L'Esclavage sous Néron: statut juridique et condition réelle. Neronia, Actes du 2 col. De la Soc. Int. d'Et. Néroniannus, ClermontFerrand, 1982, pp. 13/22.

ANDREAU, Jean. De l'esclavagisme aux esclaves gestionnaires. Topoi, 9, 1999, pp. 103-112.

. O liberto. In: GIARDINA, Andréa. O homem romano. Lisboa: Presença, 1992, pp. 149/165.

ARAÚJO, Patrícia; SÁ, Clarice. São Paulo tem maior índice de empregos formais entre as chefes de família. Jornal o Globo,

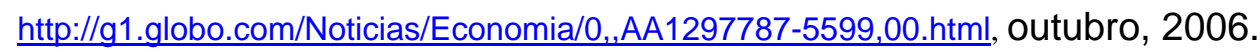

ARENDT, Hannah. A condição humana. Rio de Janeiro: Farense Universitária, 1983.

. Da violência. Brasília: UNB, 1985.

. O que é política. Rio de Janeiro: Bertrand Brasil, 1988.

. A dignidade da política. Rio de Janeiro: Relum e Dumara, 1993.

. Entre o passado e o futuro. São Paulo: Perspectiva, 2003.

ASSIS, Machado de. Memórias póstumas de Brás Cubas. São Paulo: Abril Cultural, 1978.

ATKINSON, J. E. Seneca's Consolatio ad Polybium. Aufstieg und Niedergang der Römischen Welt, Berlin, 1985, pp. 860/884. 
AUERBACH, E. Mimesis: a representação da realidade na literatura ocidental. São Paulo: Perspectiva, 1987.

AZEVEDO, Fernando de. No tempo de Petrônio. São Paulo: Melhoramentos, 1962.

BACZKO, Bronislaw. Los imaginarios sociales: memorias y esperanzas colectivas. Buenos Aires: Nueva Visión, 1991.

BACHRACH, P.; BARATZ, Morton. Power and Poverty. Theory and Practice. New York: Oxford University Press, 1970.

BAKHTIN, M. Problemas da poética de Dostoievski. Tradução de Paulo Bezerra. Rio de Janeiro: Forense-Universitária, 1981.

- A cultura popular na Idade Média e no Renascimento. São Paulo/Brasília: HUCITEC, 1999.

BALANDIER, G. As dinâmicas sociais. Sentido e poder. São Paulo: DIFEL, 1976.

. Antropologia Política. São Paulo: USP, 1969.

. O poder em cena. Brasília: UNB, 1982.

. A desordem: elogio do movimento. Rio de Janeiro: Bertrand Brasil, 1997.

. O contorno: poder e modernidade. Rio de Janeiro: Bertrand Brasil, 1997.

BALSDON, J. P. V. D. Humor e Sátira. In: BALSDON, J. P. V. D. (org.). O mundo romano. Rio de Janeiro: Zahar, 1965, pp. 232/249.

BANDEIRA, Manuel. Poesia completa e prosa. Rio de Janeiro: Nova Aguilar S.A., 1986.

BARBARA, L. Claudius. London: Routledge, 2001.

BARROS, D. L. Teoria do Discurso: fundamentos semióticos. São Paulo: Atual, 1988.

. Teoria semiótica do texto. São Paulo: Ática, 1990.

BARROSO, Edison Vicentini. Pão da indigestão. Consultor Jurídico, Www.conjur.com.bri, julho, 2006.

BARTSCH, S. Actors in the audience. Theatricality and Doublespeak from Nero to Hadrian. London: Cambridge, 1994. 
BARTHES, Roland. O rumor da língua. Tradução de Mario Laranjeira. São Paulo: Brasiliense, 1988.

BAUZÁ, Hugo F. El mito del héroe. Morfología y semántica de la figura heroica. México: Fundo de Cultura Econômica, 1998.

BRADLEY, K. R. Slavery and Society at Rome. Cambridge: Cambridge University Press, 1994.

. The Problem of Slavery in Classical Culture (Review article). Classical Philology, 92, 1997, pp. 273-282.

BRAIT, Beth. Ironia em perspectiva polifônica. Campinas: Unicamp, 1996.

BRAREN, Ingeborg. Da Clemência de Sêneca. São Paulo: FFLCH/USP (Dissertação de Mestrado), 1985.

.O mausoléu de Augusto e a Apocolocintose de Sêneca. Revista Brasileira de Estudos Clássicos, São Paulo, № 7/8, 1994/1995, pp. 165/170.

. Por que Sêneca escreveu as Epístolas? Letras Clássicas, São Paulo, no 03, 1999, pp. 39/44.

BRIQUEL, Dominique. "Petite histoire d'une grande idée: l'ouverture de la citoyennete aux anciens esclaves, source de la puissance de Rome". Acta Classica, 36, 2000, pp. 31/49.

BEACHAM, R. C. The roman theatre and its audience. London: Routledge, 1995.

BELLEZA, N. Teatro grego e teatro romano. Rio de Janeiro: Pongetti, 1961.

BELVEDERE, O. Opere publiche ed edifice per lo spettacolo nella Sicilia di età imperiale. Aufstieg und Niedergang der Römischen Welt, Berlin, 1988, pp. 347/413.

BERTELLONI, Francisco. Ethica, Oeconomica, Politica: la división tripartida de La Philosophia Practica como instrumento de análisis de fenómenos y teorias sociopolíticos. In: BENOIT, Héctor; FUNARI, Pedro Paulo A. Ética e política no mundo antigo. Campinas: Unicamp, 2001, pp. 29/44.

BOSI, Alfredo. Cultura como tradição. In: NOVAES, Adauto (org). Tradição/Contradição. Rio de Janeiro: Jorge Zahar, 1987, pp. 33/58.

. História Concisa da literatura brasileira. São Paulo: Editora Cultrix, 1994.

BOUDON, Raymond (org.). Tratado de Sociologia. Rio de Janeiro: Jorge Zahar, 1995. 
. Ação. In: BOUDON, R. Sociologia. Rio de Janeiro: Jorge Zahar, 1995, pp. 27/63.

BOULVERT, Gérard. \& MORABITO, Morabito. Les droit de l'esclavage sous le Haut-Empire. Aufstieg und Niedergang der Römischen Welt, Berlin, 1982, pp. 98/182.

BOURDIEU, Pierre. Esboço de uma teoria da prática. In: ORTIZ, Renato. Pierre Bourdieu. São Paulo: Ática, 1983.

. O poder simbólico. Lisboa/Rio de Janeiro: Difel/Bertrand Brasil, 1989.

. Coisas ditas. São Paulo: Brasiliense, 1990.

. A economia das trocas simbólicas. São Paulo: Perspectiva, 1992. . Ilusão biográfica. In: Ferreira, Marieta de Moraes e AMADO, Janaína (orgs.) Usos e abusos da história oral. Rio de Janeiro: FGV, 1996, pp. 182/191. . Economia das trocas lingüísticas. São Paulo: Edusp, 1998.

. Razões Práticas: sobre uma teoria da ação. Campinas: Papirus, 2001. BOUTRY, Philippe. Certezas e descaminhos da razão histórica. In: BOUTHIER, Jean; Julia, Dominique (org.). Passados recompostos: campos e canteiros da História. Rio de Janeiro: FGV, 1998, pp. 65/77.

BOWMAN, Alan K.; WOOLF, Greg. Cultura escrita e poder no mundo antigo. São Paulo: Ática, 1998.

BURKE, P. A fabricação do rei: a construção da imagem pública de Luís XIV. Rio de Janeiro: Jorge Zahar, 1994.

. O mundo como teatro. Estudos de Antropologia Histórica. Tradução de Vanda Maria Anastácio. Lisboa: DIFEL, 1992.

BUSTAMANTE, Regina M. da Cunha. Ludi Circenses: comparando textos escritos e imagéticos. Phoînix, Rio de Janeio, 11, 2005, pp. 221/245.

. Práticas culturais no Império Romano. In: SILVA, G. V. da; MENDES, N. M. (orgs). Repensando o império romano: perspectiva socioeconômica, política e cultural. Rio de Janeiro: Mauad; Vitória, ES: EDUFES, 2006, pp. 109/136.

. "Comida, diversão e arte" entre a elite no Império Romano: análise comparada de textos escritos e imagéticos. In: $V$ Encontro Nacional do GT de História Antiga da ANPUH Nacional, 2006, Goiânia. Programação e Resumos do V Encontro Nacional do GT de História Antiga da ANPUH Nacional. Goiânia: Faculdade de Ciências Humanas e Filosofia / UFG, v. 1, 2006, pp. 6-6. 
BRUNT, P. A. Trabalho e escravidão. In: Balsdon, J. P. V. D. (org). O mundo romano. Tradução de Victor M. de Morais. Rio de Janeiro: Zahar, 1968, pp. $169 / 181$.

. Stoicism and the Principate. PBSR, XLIII, 1975, pp. 07/35.

. La plebe urbana. In FINLEY, M. I. Estudios sobre Historia Antigua. Madrid: Akal, 1983, pp. 87/117.

. II lavoro umano. In: WACHER, John (org). II mondo di Roma Imperiale (vol. III Economia, Società e Religione). Roma: Laterza, 1989, pp. 185-205.

BRUN, Jean. El estoicismo. Buenos Aires: Eudeba, 1962.

CALVINO, Ítalo. As cidades invisíveis. Tradução de Diogo Mainardi. São Paulo: Companhia das Letras, 1990.

CAMERON, A. Circus factions: blues and Greens at Rome and Byzantium. Oxford: Clarendon, 1976.

CAMPOS, J. A. Segurado e. Introdução. In: Sêneca, L. A. Cartas a Lucílio. Tradução, Prefácio e Notas de J. A. Segurado. Lisboa: Fundação Calouste Gulbenkian, 1991, pp. V/ L.

CÂNDIDO, Antônio. Formação da literatura brasileira. Belo Horizonte: Itatiais, 1993.

. O mundo desfeito e refeito. In: Recortes. São Paulo: Companhia das Letras, 1993, pp. 30/34.

CANESSA, M. Eugenia Pareti de. Sêneca: um noble romano frente al poder imperial (ler. Siglo de nuestra era). Revista de Historia Universal, Mendoza/Argentina, 1990, pp. 73/96.

CAPPELLO, Héctor Manuel. Efeitos da globalização econômica sobre a identidade e o caráter das sociedades complexas. Um estudo comparativo entre as populações do Norte e do Sudeste mexicano no que diz respeito à identidade e ao caráter nacionais. In: MENDES, Cândido (org.). Pluralismo Cultural, Identidade e globalização. Rio de Janeiro: Record, 2001, pp. 115/145.

CARCOPINO, J. Roma no apogeu do império. Prefácio de Raymond Bloch e tradução de Hildegard Feist. São Paulo: Companhia das Letras, 1990.

CARDOSO, Ciro Flamarion. Narrativa, sentido e História. Campinas: Papirus, 1997.

. Sete olhares sobre a Antigüidade. Brasília: UNB, 1998. 
Cardoso, Ciro Flamarion; ARAÚJO, Sônia Regina Rebel de. A sociedade Romana no Alto Império. In: SILVA, G. V. da; MENDES, N. M. (orgs). Repensando o império romano: perspectiva socioeconômica, política e cultural. Rio de Janeiro: Mauad; Vitória, ES: EDUFES, 2006, pp. 85/106.

CARDOSO, Zélia de Almeida. El discurso de Hipólito em la Fedra de Sêneca y el rechazo de la Vrbs. In: Actas del XIII Simposio Nacional de Estudios Clasicos, Universidad Nacional de la Plata, Vol. I, 1996, pp. 71/110.

. Política e poder nas obras de Sêneca. Phoînix, Rio de Janeiro, 9, 2003, pp. 360/379.

. Estudo sobre as tragédias de Sêneca. São Paulo: Alameda, 2005.

CARANDINI, Andrea. Archeologia e Cultura materiale. Daí "Lavori Aenza Gloria" nell'Antichità a una Politica dei Beni Culturali. Bari: De Donato, 1979.

CASSIRER, Ernest. Linguagem, mito e religião. Porto: Rés, 19?

CASTELLO, Carlo. "Humanitas e Favor Libertatis: Schiavi e Liberti nel I Secolo". In Sodalitas: Scriti in Onore di Antonio Guarino, v. 5. Nápoles: Editore Jovene, 1984, pp. 2175-2189.

CASTELLS, Manuel. A era da informação: economia, sociedade e cultura. $O$ poder da identidade (vol. II). São Paulo: Paz e Terra, 1999.

CASTRO, Fábio de. Mercado de trabalho mais acessível. Boletim Agência

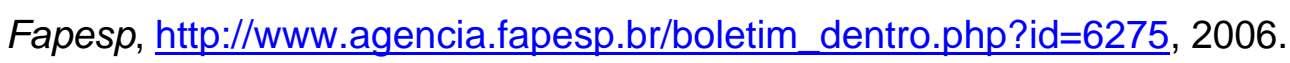

CHAUI, Marilena. Ignorância e verdade. In: A verdade. São Paulo: Ática, 1998, p. 90/99.

CAZZANGA, Gian Mario. "Stratificazione sociale, rapporti di dipendenza e forme servili nel mondo antico". In SICHIROLLO, Livio (ed.). Schiavitù antica e moderna: problemi, storia, istituzioni. Nápoles: Guida Editori, 1979, pp. 139158.

CHARTIER, Roger; CAVALLO, Guglielmo. Introdução. In: CHARTIER, Roger; CAVALLO, Guglielmo (orgs.). História da leitura no mundo ocidental. São Paulo: Ática, 1998, pp. 05/40.

CHARTIER, Roger. A história cultural entre práticas e representações. Lisboa: Difel, 1990.

Pour comprendre l'histoire. Le Monde, Jeudi 18 mars, 1993.

CHAUMARTIN, F. R. Les désillusions de Sénèque devant l'évolution de la politique néronienne et l'aspiration à la retraite: le 'De uita beata' et le 'De 
beneficiis'. Aufstieg Und Niedergang Der Römischen Welt (ANRW), vol. 36.3, Berlin, 1989, pp. 1686/1723.

CHRISTCHURCH, C. E. Manning. Stoicism an slavery in the Roman Empire. Aufstieg Und Niedergang Der Römischen Welt (ANRW), vol. 36.3, Berlin, 1989, pp. 1518/1543.

CLAVEL-LÉVÊQUE, Monique. L'empire en jeux: space symbolique et pratique sociale dans le monde romain. Paris: Editions du centre National, 1984.

. L'espace des jeux dans le monde romain: hégémonie, symbolique et pratique sociale. Aufstieg und Niedergang Der Römischen Welt, Berlin, W. de Gruyter, 1986, II, 16, 3, pp. 2406/2563.

CLAVEL-LÉVÊQUE; FAVORY, F. Pratique scientifique et theorie des sociétés de l'Antiquité. 1977.

CLOUD, Duncan. The client-patron relationship: emblem and reality in Juvenal1s first book. In: WALLACE-HADRIL, Andrew. Patronage in Ancient Society. London: Routledge, 1990, pp. 205-218.

CERVELLERA, Maria Antonietta. "Alcune notazioni su tematica e metafora del potere in Seneca". Rudiae, 4, 1992, pp. 101-115.

CHIAPETTA, Angélica. De Tranquilitate Animi como exercício spiritual. Letras Clássicas, no 03, São Paulo, 1999, pp. 23/38.

CIZEK, E. Néron. Paris: Fayard, 1982.

CORASSIN, Maria Luiza. Edifícios de espetáculos em Roma. Clássica, São Paulo, v. 09/10, no 09/10, 1996/1997, pp. 119/131.

. Bacchanalia na república romana. In: BENOIT, Hector \& FUNARI, Pedro Paulo A. Ética e política no mundo antigo. Campinas: Unicamp, 2001, pp. 45/62.

. Sociedade e política na Roma antiga. São Paulo: Atual, 2001.

. Sêneca entre a colaboração e a oposição. Letras Clássicas, São Paulo, no 03, 1999, pp. 275/285.

CORBIER, Mirelle. De Volsinii a Sestinum: AQVAE et évergétisme municipal de l'eau em Italie. Revue des Études Latines, Paris, Les Belles Lettres, 1985, pp. 236/274.

CORTEN, A. Discurso e representação do político. In: INDURSKY, F.; CRISTINA, M.; FERREIRA, L. Os múltiplos territórios da análise do discurso. Porto Alegre: Sagra Luzatto, 1989, pp. 37/59. 
COUTINHO, Afrânio. Literatura no Brasil (vol. II). São Paulo: Global, 2003.

CROISILLE, Jean-Michel. Caton et Sénèque face au pouvoir: Lucain Pharsale. Neronia 1977, 1982, pp. 77/82.

. Néron a tué Agrippine. Bruxelles: Complexe, 1994.

DABDAB TRABULSI, J. A. Ensaio sobre a mobilização política na Grécia antiga. Belo Horizonte: UFMG, 2001.

DAMATTA, Roberto. O carnaval como um rito de passagem. In: Ensaios de antropologia estrutural. Petrópolis: Vozes, 1973, pp. 121/168.

- Carnavais, malandros e heróis: para uma sociologia do dilema brasileiro. Rio de Janeiro: Zahar, 1979.

. A casa \& a rua: espaço, cidadania, mulher e morte no Brasil. São Paulo Brasiliense, 1985.

- Explorações: ensaios de sociologia interpretativa. Rio de Janeiro: Rocco, 1986.

- Conta de Mentiroso. Sete ensaios de Antropologia Brasileira. Rio de Janeiro: Rocco, 1993.

Águias, burros e borboletas: um estudo antropológico do jogo do bicho. Rio de Janeiro: Rocco, 1999.

- Globalização e identidade nacional: considerações a partir da experiência brasileira. In: MENDES, Cândido (org.). Pluralismo Cultural, Identidade e globalização. Rio de Janeiro: Record, 2001, pp. 168/199.

. O que é o Brasil? Rio de Janeiro: Rocco, 2004.

DE CERTEAU, Michel. A invenção do cotidiano. Petrópolis: Vozes, 1996.

DEHON, Pierre-Jacques. Une paradie de Sénèneque chez Pétrone. Revue des Études Latines, Paris, Les Belles Lettres, 1994, pp. 33/36.

DELGADO, Andréa. Diálogos (im)possíveis ou trama dos discursos. In: RAGO, Margareth \& GIMENES, Renato A. de Oliveira (orgs). Narrar o passado, repensar a História. Campinas: Unicamp, 2000, pp. 175/191.

DENIAUX, Elizabeth; SCHMITT-PANTEL, Pauline. La relation patron-client en Grèce et à Rome. Opus, 6-8, 1987-89, pp. 147-160.

DEMO, Pedro. Ciência, ideologia e poder: uma sátira as ciências sociais. São Paulo: Atlas, 1988. 
De Robertis, Francesco Maria. Storia sociale di Roma: le classi inferiori: corso di storia romana, parte speciale; Contributi varii alla storia economica e sociale di Roma. Roma: "L'Erma" di Bretschneider, 1981.

DIJON, Jean-Marie André. Sénèque: 'De Breuitate uitae', 'De Constantia Sapientis', De Tranquilitate Animi', 'De Otio'. Aufstieg Und Nierdergang Der Römischen Welt (ANRW), vol.36.3, 1989, pp. 1724/1778.

DIJK, Teun A. Van. Cognição, discurso e interação. São Paulo: Contexto, 1999. DUBOIS, Jacques. Retórica geral. São Paulo: Cultrix, 1974.

DUCOS, Michèle. Théâtre at société dans l'empire romain. Gutenberg: Gutenberg-Universität Mainz, 1990.

DUPONT, Florence. Le prologue de la Phèdre de Sénèque, Revue des Études Latines, Paris, Les Belles Lettres, 1992, pp. 124/135. . L'acteur-roi: le theater dans la Rome antique. Paris: Les Belles Lettres, 2003.

DRUMMOND, A. Rome in the fifth century II: the citizen Commnity. The Cambridge Ancient History, Vol. VII, part. 2, Cambridge University Press, 1989. pp. 172/242.

ECO, U. Semiótica e filosofia da linguagem. Tradução de Mariarosaria Fabris e José Luiz Fiorin. São Paulo: Ática, 1991.

ECK, Werner. "La dipendenza come concetto ambivalente: a proposito del rapporto tra patrono e liberto". In ECK, Werner. Tra epigrafia, prosopografia e archeologia. Scritti scelti, rielaborati ed aggiornati. Roma: Edizioni Quasar, 1996, pp. 165/174.

EDWARDS, Catharine. Self-scrutiny and self-transformation in Seneca's Letters. Greece \& Rome, vol. xliv, № 1, April, 1997, pp. 23/38.

ELSNER, Jás; MASTERS, Jamie. Reflections of Nero: culture, history \& representation. London: Hoxton Square, 1994.

ELSTER, Jon. Peças e engrenagens das Ciências Sociais. Rio de Janeiro: Relume-Dumará, 1995.

FABRE, George. "Mobilité et stratification: le cas des serviteurs impériaux". In FREZOULS, Edmond (ed.). La mobilité sociale dans le monde romain. Actes du colloque organisé à Strasbourg (nov. 1988). Strasbourg: AECR, 1992, pp. $123 / 159$. 
FARES, Cláudia. Alguma coisa está fora da nova ordem mundial: a construção de uma identidade. In: MENDES, Cândido (org.). Pluralismo Cultural, Identidade e globalização. Rio de Janeiro: Record, 2001, pp. 182/1999.

FARO, Silvano. La Libertas ex Diui Claudii Edicto: Schiavitù e Valori morali nel I secolo D.C. Catania: Edizioni del Prisma, 1996.

FAVERSANI, Fábio. As relações diretas de poder enquanto instrumento analítico para a compreensão da pobreza no Satyricon de Petrônio. História Revista, Goiânia, vol. 1,1, 1986, pp. 43/70.

. Cultura popular e classicismo. LPH: Revista de Historia, Mariana, v. 4, 1994, pp. 14-25.

. Trimalchio, classe social e estamento. Revista de História, São Paulo, vol. 134, 1996, pp. 07/18.

. A tipicidade de Trimalchio. História, Marilia, vol. 15, 1996, pp. 245/252.

. A Concepção de Estado em Sêneca. Boletim do CPA. Campinas, no 5/6, jan./dez., 1998, pp. 223/234.

. Popper, Ciência e História Antiga. Síntese Nova Fase, Belo Horizonte, v. 25, no 83,1998 , pp. 527550.

. A pobreza no Satyricon de Petrônio. Ouro Preto: UFOP, 1999.

- Panem et circenses: Breve análise de uma perspectiva de incompreensão da pobreza no Mundo Romano. Varia História, Belo Horizonte, v. 22, 2000, pp. 81-87.

. A sociedade em Sêneca. São Paulo: USP/FFLCH, 2000.

FACCHINI, G. M.; CHIESA, G. S. Gemme romane di età imperiale: produzione, commerci, committenze. Aufstieg und Niedergang der Römischen Welt, Berlin, 1985, pp. 03/31.

FEITOSA, Lourdes M. G. Conde. Amor e sexualidade no popular pompeiano: uma análise de gênero em inscrições parietais. Campinas: Unicamp, 2002 (Tese de Doutoramento).

. História, gênero, amor e sexualidade: olhares metodológicos. Revista do Museu de Arqueologia e Etnologia da USP, São Paulo, v. 13, 2003, pp. 101115.

Amor e sexualidade: o masculino e o feminino em grafites de Pompéia. São Paulo: Annablume, 2005. 
FELDHERR, Andrew. Spectacle and society in Livy's history. Berkeley: University of California Press, 1988.

FREDERIKESEN, M. W. Cidades e habitações. In: Balsdon, J. P. V. D. (org). O mundo romano. Tradução de Victor M. de Morais. Rio de Janeiro: Zahar, 1968, pp. 151/167.

FREEMAN, Charles. Egypt, Greece and Rome. Oxford: University Press, 1999. FRIEDLAENDER, L. La sociedad roman. Historia de las costumbres en Roma, desde Augusto basta los Antoninos. México: Fundo de Cultura econômica, 1947.

. Moeurs romaines. Paris: C. Reinwald, 1867.

FRYE, Northrop. Crítica arquetípica: teoria dos mitos. In: Anatomia da Crítica. Tradução de Péricles Eugênio da Silva Ramos. São Paulo: Cultrix, 1973, pp. $133 / 235$.

FINI, Massimo. Nero: o imperador maldito. Dois mil anos de mentiras. Tradução de Mércia Justum. São Paulo: Scritta, 1993.

FINLEY, M. I. Economia e sociedade na Grécia Antiga. São Paulo: Martins Fontes, 1989.

. Escravidão Antiga e Moderna. Rio de Janeiro: Graal, 1991. . Política no mundo antigo. Lisboa: Edições 70, 1997.

FIORIN, J. L. Linguagem e Ideologia. São Paulo: Ática, 1988. . Regime de 64: discurso e ideologia. São Paulo: Atual, 1988. . Elementos da análise do discurso. São Paulo: Contexto, Edusp, 2001. FONTANA, Josep. A História após a crise de 1989. In: História depois do fim da História. Tradução de Antônio Penalves Rocha. Bauru: Edusc, 1998, pp. 07/38.

FOUCAULT, Michel. A microfísica do poder. Organização e tradução de Roberto Machado. Rio de Janeiro: Graal, 1986.

. Espaço e Poder (Entrevista de Michel Foucault a Paul Rabinow). Tradução de Heloísa Buarque de Holanda e Lucia Canedo. Revista do Patrimônio Histórico e Artístico Nacional. Rio de Janeiro, ํo 23, 1994, pp. 139/145.

A ordem do discurso. São Paulo: Loyola, 1996.

. História da Sexualidade. O Uso dos prazeres. Rio de Janeiro: Graal, 1998. 
FORABOSCHI, Daniele. Movimenti e tensioni sociali nell'Egitto romano. Aufstieg und Niedergang der Römischen Welt, Berlin, 1988, pp. 807/840.

FUNARI, Pedro Paulo de Abreu. Cultura popular en la Antigüedad Clásica. Madrid: Sol, 1989.

. Os debates historiográficos sobre Antigüidade Clássica e as Ciências Humanas: Letras, Literatura e Lingüística. Argos, n²1, Buenos Aires, ano XXI, 1997, pp. 25/32.

. Política e Riso em Pompéia: ensaio sobre a crítica social popular. In: FUNARI, P. P. A.; BENOIT, H. Ética e política no mundo antigo. São Paulo: Unicamp, 2001, pp. 117/132.

- Grécia e Roma: vida pública e vida privada, cultura, pensamento e mitologia, amor e sexualidade. São Paulo: Contexto, 2001. . A vida cotidiana na Roma antiga. São Paulo: Annablume, 2003. - Fontes arqueológicas - os historiadores e a cultura material. In: PINSKY, Carla Bassanezi (Org.). Fontes Históricas. São Paulo: Contexto, 2006, pp. 81-110.

FUNARI, P. P. A.; SILVA, G. J. da; FEITOSA, L. Conde (orgs). Amor, desejo e Poder na Antigüidade Clássica. Campinas: Unicamp, 2003.

FUNARI, P. P. A.; GARRAFFONI, R. S. Economia romana no inicio do Principado. In: SILVA, G. V. da; MENDES, N. M. (orgs). Repensando o império romano: perspectiva socioeconômica, política e cultural. Rio de Janeiro: Mauad; Vitória, ES: EDUFES, 2006, pp. 53/63.

GALBRAITH, J. K. Anatomia do poder. São Paulo: Pioneira, 1989.

GRAMSCI, Antônio. Gramsci: sobre poder, política e partido. São Paulo: Brasiliense, 1990.

GRANT, M. El mundo romano. Madri: Guadarrama, 1960.

GADET, F \& HAK, T. (org.) Por uma análise automática do discurso: uma introdução á obra de Michel Pêcheux. Campinas: Unicamp, 1990.

GARRAFFONI, R. S. Gladiadores na Roma Antiga: dos combates às paixões cotidianas. São Paulo: Annablume, 2005.

- Panem et circenses: máxima antiga e a construção de conceitos modernos. Phoînix, Rio de Janeiro, 11, 2005, pp. 246/267.

GAZOLA, Rachel. O ofício do filósofo estóico: o duplo registro do discurso da stoa. São Paulo: Loyola, 1999. 
GAGÉ, J.. Recherches sur les Jeux séculaires. Paris: Les Belles Lettres, 1934. . Les milieux populares: des plèbes indigènes aux affranchis. In: Les classes sociales dans l'empire romain. Paris: Payot, 1964, pp. 123/154. . La mystique Impériale et l'épreuve des jeux. Commode - Hercules. Aufstieg und Niedergang der Romischen Welt II - Principat - Religion, Berlin, Walter de Gruyter, 17.2, 1986, pp. 662/683.

GARFUNKEL, Jean; GARFUNKEL, Paulo. Contumaz. In: Braz, Renato. Por toda a vida. As canções de Jean e Paulo Garfunkel. Estados Unidos: Dixon Van Winkle, 2006.

GARNSEY, P.; SALLER, R. Non-slave labour in the Greek-Roman World. Cambridge: Cambridge University Press, 1980.

. The early principate. Augustus to Trajan. Oxford: At Clarendom Press, 1982.

. Storia sociale dellimpero romano. Roma: Laterza, 1989.

. L'Empire romain: économie, société, culture. Paris: la Découverte \& Syros, 2001.

Garnsey, Peter. Alimentação e sociedade na antiguidade clássica: aspectos materiais e simbólicos dos alimentos. Lisboa: Replicação, 2002.

GAUDEMET, Jean. "Esclavage et dépendance dans l'Antiquité". In GAUDEMET, Jean. Droit et société aux derniers siècles de l'Empire Romain. Nápoles: Jovene Editore, 1992, pp. 237-274.

GAULIN, Jean-Louis. A ascese do texto ou etorno às fontes. In: BOUTHIER, Jean; Julia, Dominique (org.). Passados recompostos: campos e canteiros da História. Rio de Janeiro: FGV, 1998, pp. 173/182.

GAY, Peter. O estilo na História: Gibbon, Ranke, Macaulay, Burckhardt. Tradução de Denuse Bottmann. São Paulo: Companhia das Letras, 1990. GUARINELLO, Norberto Luis. Nero, o estoicismo e a historiografia romana. Boletim do CPA, Campinas, nº 01, jan./jun., 1996, pp. 53/61. . Poder e política no mundo romano. São Paulo: Edusc, 2000. . Festa, trabalho e cotidiano. São Paulo: Hucitec/Edusp, 2001, pp. 969/975.

. Uma morfologia da História: as formas da História Antiga. Politéia, Vitória da Conquista, v. 3, ㄲo 1, 2003, pp. 41-62. 
O império romano e nós. In: In: SILVA, G. V. da; MENDES, N. M. (orgs). Repensando o império romano: perspectiva socioeconômica, política e cultural. Rio de Janeiro: Mauad; Vitória, ES: EDUFES, 2006, pp. 13/19.

GUARINELLO, Norberto Luis; JOLY, Fábio Duarte. Ética e ambigüidade no principado romano. In: BENOIT, Héctor; FUNARI, Pedro Paulo A. Ética e política no mundo antigo. Campinas: Unicamp, 2001, pp. 133/152.

GRAMMATICO, Giuseppina. Silencio y furor en la Apokolokinthosis de Sêneca. Letras Clássicas, São Paulo, oㅜ 3, 1999, pp.109/127.

Grant, M. Atlas of Classical History. London: Routledge, 1994.

GEERTZ, Clifford. A interpretação das culturas. Rio de Janeiro: J. Zahar, 1978.

GREIMAS, A. J. Semântica estrutural. São Paulo: Cultrix, 1973.

GUERRI, E. C. La sociedad romana en Seneca. Murcia: Universidad de Murcia, 1979.

GINZBURG, Carlo. Semiologia do teatro. São Paulo: Perspectiva, 1988. . Mitos, emblemas, sinais. Morfologia e história. São Paulo: Cia. Das Letras, 1991.

GIARDINA, A.. (org.). O homem romano. Lisboa: Presença, 1991, pp. 07/17. GIACCHERO, Marta. Economia e società nell'opera di Sêneca. Intituizioni e giudizi nel contesto storico dell'età Giulio-Claudia. In: Miscellanea di Studi classici in onnore di Eugenio Manni (vol. 3). Roma: Giorgio Brestschneider, 1980, pp. 1087/1136.

GILIBERTI, Giuseppe. "Beneficium e iniuria nei rapporti col servo: etica e prassi giuridica in Seneca". In Sodalitas. Scritti in Onore di Antonio Guarino, v. 4. Nápoles: Editore Jovene, 1984, pp. 1843-1860.

. Servi della Terra: Ricerche per una Storia del Colonato. Torino: G. Giappichelli Editore, 1999.

GRIFFIN, M. T. Sêneca: a philosopher in politics. Oxford: Clarendon Press, 1976.

. Seneca as a sociologist: De Beneficiis. In: VIVO, A. De \& CASCIO, E. Lo. Seneca uomo politico e l'età di Claudio e di Nerone. Bari: EDIPUGLIA, 2003.

GRIMAL, Pierre. La vie a rome dans I'antiquite. Paris: Presses Universitaires de France, 1972. . Les erreurs de la liberte. Paris: Les Belles Lettres, 1989. 
. A la recherche de l'italia antique. Paris: Les Belles Lettres, 1989.

. Erros da liberdade. Campinas: Papirus, 1990.

. Sénèque ou la conscience de l'empire. Paris: Fayard, 1991.

- Sénèque et le stoïcisme romain. Aufstieg Und niedergang der Römischen Welt, vol. 36.3, Berlin, 1989, pp. 1962/1992.

. L'image du pouvoir royal dans les tragédies de Sénèque. Pallas, 38, 1992, pp. 409/415.

. A vida em Roma na Antigüidade. Mira-Sintra: Europa-America, 1995.

. O império romano. Lisboa: Edições 70, 1999.

. A civilização romana. Lisboa: Edições 70, 2001.

.O teatro antigo, Lisboa: Edições 70, 2002.

GRISÉ, Yolande. Le suicide dans la Rome Antique. Paris: Les Belles Lettres, 1982.

GONÇALVES, A. T. M. As imagens estóicas na Fedra de Sêneca. Phoînix, Rio de Janeiro, 2, 1996, pp. 47/56.

- Cidadania e Exílio na Obra Consolação a Minha Mãe Hélvia de Sêneca. Phoînix, Rio de Janeiro, v. 4, 1998, pp. 39-46.

. Uma análise da obra De Clementia de Sêneca: a noção de virtude. Phoînix, Rio de Janeiro, 1999, pp. 51/74.

. Plebe urbana de Roma e grupos provinciais no período de Severiano: o testemunho de Herodiano. Helade 1 (1), 2000, pp. 2/16.

- A construção da imagem imperial: formas de propaganda nos governos de Septímio Severo e Caracala. São Paulo: FFLCH/USP, 2002 (Tese de Doutoramento).

GOFFMAN, Erving. A representação do eu na vida cotidiana. Petrópolis: Vozes, 1983.

HALL, Stuart. Identidade Cultural na pós-modernidade. Tradução de Tomaz Tadeu da Silva e Guacira Lopes Louro. Rio de Janeiro: DP\&A, 1999.

HARTOG, François. A arte da narrativa histórica. In: BOUTHIER, Jean; Julia, Dominique (org.). Passados recompostos: campos e canteiros da História. Rio de Janeiro: FGV, 1998, pp. 193/202.

HAUPT, Heinz-Gerhard. O lento surgimento de uma História Comparada. In: BOUTHIER, Jean; Julia, Dominique (org.). Passados recompostos: campos e canteiros da História. Rio de Janeiro: FGV, 1998, pp. 205/216. 
HIBBERT, C. La Rome impériale. In: Histoire de Rome. Paris: Ed. Payot, 1988, pp. 33/67.

HIMMELFARB, G. La idea da pobreza. Mexico: Fondo de Cultura Económica, 1986.

HOBSBAWM, Eric. Sobre História: ensaios. Tradução de Cid knipel Moreira. São Paulo: Companhia das Letras, 1998.

HOMO, L. Rome impériale et l'urbanisme dans l'Antiquité. Paris: Albin Michel, 1971.

HOPKINS, Keith. Conquistadores y esclavos. Barcelona: Peninsula, 1981.

HUNT, L. História, Cultura e Texto. In: HUNT, L. (org.). A nova História Cultural. São Paulo: Martins Fontes, 1995, pp. 01/29.

HUSBAND, Richard Wellington. Galba's assassination and the indifferent citizen. Classical Philology, Vol. 10, oㅜ 3, Jul., 19?, pp. 321/325.

JACQUES, François. Les cités de l'occident romain. Paris: Les Belles Lettres, 1992.

JACQUES, F. \& SCHEID, J. Roma e il suo Impero: istituzioni, economia, religione. Roma: Laterza, 1992.

JANNOT, Jean-René. Les danseurs de la pompa du cirque: témoignages textuels et iconographiques. Revue des Études Latines, Paris, Les Belles Lettres, 1993, pp. 56/68.

JOLY, F. D. Tácito e a metáfora da escravidão. São Paulo: Edusp, 2004.

. A escravidão na Roma Antiga. Política, economia e cultura. São Paulo: Alameda, 2005.

. Terra e trabalho na Itália no Alto Império. In: SILVA, G. V. da; MENDES, N. M. (orgs). Repensando o império romano: perspectiva socioeconômica, política e cultural. Rio de Janeiro: Mauad; Vitória, ES: EDUFES, 2006, pp. 65/84.

- Libertate opus est. Escravidão, Manumissão e cidadania a época de Nero (54 a 68 d.C.). São Paulo: FFLCH, 2006 (Tese de Doutoramento). KANTOROWICZ, Ernest H. Os dois corpos do rei: um estudo sobre teologia política medieval. São Paulo: Companhia das Letras, 1998.

KONSTAN, David. A amizade no mundo clássico. São Paulo: Odysseus, 2005. LAHILLE, J. F. La production de Sénèque sous les règnes de Caligula et de Claude, sens philophique et portée politique: les 'Consolations' et le 'De Ira'. 
Aufstieg und Niedergang der Römischen Welt, vol. 36.3, Berlin, 1989, pp. 1606/1637.

LAURENCE, Ray. Rumor and communication in roman politics. Greece \& Rome, 2nd Ser., vol. 41, no 1, Apr., 1994, pp. 62-74.

LENDON, J. E. Empire of honour. The art of government in the roman world. Oxford: Clarendon Press, 1997.

LEVI, Mario Attilio. Nerone e i suoi tempi. Milano: Istituto Editoriale Cisalpino, $199 ?$

LEGENDRE, Pierre. Le désir politique de Dieu; étude sur les montages de l'État et du droit. Paris: Fayard, 1988.

LEVICK, BARBARA. Claudius. London: ROUTLEDGE, 2001.

LÉVY-BRUHL, H. "Théorie de l'esclavage". In: FINLEY, M. I. (ed.). Slavery in Classical Antiquity. Cambridge: W. Heffer \& Sons, 1960, pp. 151-169.

LYONS, J. Introdução à lingüística teórica. São Paulo: Nacional, Edusp, 1979.

LOPES, Fábio Henrique. A história em Xeque: Michel Foucault e Hayden White. In: RAGO, Margareth; GIMENES, Renato Aloizio de Oliveira (orgs.) Narrar o passado, repensar a História. Campinas: Unicamp, 2000, pp. 287/308. LOPOSZKO, Tadeusz. Propagande politique de Cicéron em 63 av. J. -C. In: DOI, M.; YUGE, T. Forms of control and subordination in Antiquity. Leiden:E. J. Brill, 1988. p. 377/409.

LOZANO, Jorge. El discurso histórico. Lisboa: Alianza, 1987.

MAGDELAIN, André. Sénèque et le paradoxo de felicitas. Revue des Études Latines, Paris, Les Belles Lettres, 1994, pp. 25/32.

MAIURI, A. les grands siècles de la peinture: la peinture romaine. Suisse: Copyright, 1953.

MANCIOLI, Danila. Giocchi ed spetacolli. Roma: Quasar, 1987.

MACHADO, Roberto. Por uma genealogia do poder. In: FOUCAULT, Michel. Microfísica do poder. Organização e tradução de Roberto Machado. Rio de Janeiro: Graal, 1986, pp. VII/ XXIII.

MARCHETTI, Mireille Armisen. Sapientiae facies: étude sur les images de Sénèque. Paris: Les Belles Lettres, 1989.

- Pourquoi Sénèque n'a-t-il pas écrit l'histoire? Revue des Études Latines, Paris, Les Belles Lettres, 1996, pp. 151/167. 
MACMULLEN, R. Les rapports entre les classes sociales dans l'empire romain. 50 av. J. -C. Paris: SEUIL, 1986.

MAINNGUENEAU, D. Initiation aux méthodes de l'analyse du discours: problèmes et perspectives. Paris: Hachette, 1976.

. L'analyse du discours; introduction aux lectures de l'archive. Paris: Hachette, 1991.

. Novas tendências em análise do discurso. Tradução de Freda Indursky. Campinas: Pontes, Unicamp, 1993.

MAROLDI, Marcelo. Mentiras diplomáticas: a Copa do Mundo é nossa. Digestivo Cultural, 'www. digestivoculturâl.com, julho, 2006.

MATOS, Gregório. O que falta nesta cidade. In: Satírica (vol. IV). Rio de Janeiro: Oficina Industrial Graphica, 1930, pp. 261.

. A cavalaria da festa das virgens no tempo do governo de D. João de Alencastre, sendo juiz Gonçalo Ravasco Cavalcante de Alburquerque. In: Satírica (vol. IV). Rio de Janeiro: Oficina Industrial Graphica, 1930, pp. 53.

Meireles, Cecília. Mapa de Anatomia: o olho. In: SECCHIN, Antônio Carlos (org.). Cecília Meireles: poesia completa (vol. II). Rio de Janeiro: Nova Fronteira, 2001, pp. 1436.

MENDES, Norma Musco. As relações políticas entre o princeps e o populus

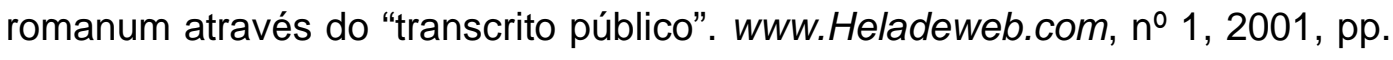
$39 / 49$.

. O sistema político do principado. In: SILVA, G. V. da; MENDES, N. M. (orgs). Repensando o império romano: perspectiva socioeconômica, política e cultural. Rio de Janeiro: Mauad; Vitória, ES: EDUFES, 2006, pp. 21/51.

MENDES, Norma Musco; OTERO, Uiara Barros. Religiões e questões de cultura, identidade, e poder no império romano. Phoînix, Rio de Janeio, 11, 2005, pp. 196/200.

MILLAR, Fergus. The emperor in the roman world. London: Hoxton Square, 1992.

. The roman city-state under the emperors: 29 BC-AD 69. Prudentia, The University of Sydney, Frances Muecke, Supplementary Number 1998, pp. 113-134.

MICCOLIS, Leila. Do poder ao poder. Porto Alegre: Tche, 1987. 
MOLINIER, Agnes. Philippe le bon roi de Cicéron à Sénèque. Revue des Études Latines, Paris, Les Belles Lettres, 1996, pp. 60/79.

MORIN, Edgar. O problema epistemológico da complexidade. Portugal: Europa-América, 2002.

MORFORD, M. Nero's patronage and participation in literature and the arts. Aufstieg Und Niedergang Der Römischen Welt, Berlin, 1985, pp. 2003/2031.

MOREL, Jean-Paul. O artesão. In: GIARDINA, Andrea. O homem romano. Trad. De Maria Jorge Vilar de Figueiredo. Lisboa: Presença, 1992, pp. 181/202.

MORTUREUX, Bernard. Les idéaux stoïciens et les premières responsabilités politiques: le "De Clementia". Aufstieg und Niedergang der Römischen Welt, Berlin, II, 36, 3, 1970, pp. 1639/1685.

MOREAU, Philippe. Violences romaines. In: GAILLARD, Jacques (org.). Rome I siècle av. J.-C.: Ainsi périt la République des vertus. Paris: Autrement, 1996, pp. 88/101.

MURRAY, OSWYN. The quinquennium Neronis and the stoics. Histoire, Cambridge, no 14, 1965, pp. 41/61.

NÉRAUDAU, Jean-Pierre. Néron et le nouveau chant de Troie. Sprache und Literatur (Literatur Der Julisch-Claudischen), 1985, pp. 2033/2045.

NETO, João Cabral de Melo. Tecendo a Manhã. In: Obra Completa (vol. único). Organização Marly de Oliveira. Rio de Janeiro: Nova Aguilar, 1994, pp. 345.

NEVES, Margarida de Souza. Os jogos da memória. In: MATTOS, Rohloff (org.). Ler e escrever para contar: documentação, historiografia e formação do historiador. Rio de Janeiro: Access, 1998, pp. 203/220.

NICOLET, Claude. O cidadão e o político. In: GIARDINA, Andrea (org.). $O$ homem romano. Lisboa: Presença, 1992, pp. 19/48.

NOVAK, Maria da Glória. Estoicismo e epicurismo em Roma. Letras Clássicas, São Paulo, № 3, 1999, pp. 147/162.

OMENA, L. M. de. A História Construindo ou Reconstruindo o Passado? Boletim do CPA, Campinas, julho/dezembro, 2000, pp. 85/96. . As estratégias de afirmação social no romance $O$ asno de Ouro, de Lúcio Apuleio. História: Questões \& Debates, Curitiba, n³4, UFPR, 2001, pp. $65 / 88$. 
A centralização do poder nas obras De Clementia e Diui Claudii Apocolocyntoses, de Sêneca. Campinas: Unicamp (Dissertação de Mestrado), 2002.

A imagem de poder do imperator sob a perspectiva de Sêneca. Revista Alpha, Patos de Minas, ano 5, n 5, 2004, pp. 63/72.

- Apocolocyntoses de Sêneca: uma alusão à troca de favores em Roma. História, Universidade Federal de Goiás, 2005, pp. 363/376.

. A fabricação da plebe sob a perspectiva de Sêneca. Stylos, Buenos Aires, n० 14 (14) 2005, pp. 119/129.

. Comemorações festivas: aspectos sociais em Sêneca. In: LESSA, F.S.; BUSTAMANTE, R.M.C. (org.). Memória e Festa. Rio de Janeiro: Mauad editora, 2005, pp. 229-234.

ORLANDI, E. P. A linguagem e seu funcionamento: as formas do discurso. Campinas: Pontes, 1987.

. As formas do silêncio. Campinas: Unicamp, 1995.

. Interpretação. Petrópolis: Vozes, 1996.

(org.) Gestos de leitura. Da História no discurso. Campinas: Unicamp,1997.

. Linguagem e método: uma questão da análise de discurso. In: Discurso e leitura. Campinas: Unicamp, 2000, pp. 15/40.

. As Histórias das Leituras. In: Discurso e leitura. Campinas: Unicamp, 2000, pp. 41/50.

. Análise de discurso. Campinas: Fontes, 2001.

(org.). Vão surgindo sentidos. In: Discurso Fundador: a formação do país e a construção da identidade nacional. Campinas: Pontes, 2001, pp. 11/25.

PAOLI, Ugo Enrico. Urbs: la vida en la Roma Antigua. Barcelona: Iberias, 19?

PASQUIA, R. Belli. Rifornimento alimentare di carne a Roma nel I-V Secolo d.C.. In: Agricoltura e commerci nell'Italia Antica. L'Erma: Bretschneider, 1995, pp. 257/272.

PAVIA, G. M. Le ‘Epistulae Morales ad Lucilium’ di Seneca. Valore letterario e filosofico. Aufstieg Und Niedergang Der Römischen Welt, vol. 36.3, Berlin, 1989, pp. 1823/1877.

PENNA, Antonio la. I/ comportamento dell'intellettuale nella società antica. Genova: Università di Genova, 1980. 
PESAVENTO, S. J.; LEENHARDT, J. (orgs). Apresentação. In: Discurso histórico e narrativa literária. Campinas: Unicamp, 1998, pp. 9/15.

PESAVENTO, Sandra Jatahy. Fronteiras da ficção: diálogos da História com a Literatura, Estudos Históricos, Franca, v. 06, n 01, 1999, pp. 55/66.

PÉCHÉ, Valérie \& VENDRIES, Christophe. Musique et spectacles à Rome et dans l'occident romain. Sous la Republique et lê Haut-Empire. Paris: Errance, 2001.

PÊCHEUX, M. Semântica e discurso: uma crítica á afirmação do óbvio. Campinas: Unicamp, 1988.

PERELMAN, C. tratado e argumentação. A nova retórica. São Paulo: Martins Fontes, 1996.

PERRING, Dominic. Spatial organisation and social change in Roman towns. In: $\mathrm{RICH}$, John; WALLACE-HADRILL, Andrew. City and country in the ancient world. London and New York: Routledge, 1994, pp. 273/293.

PETERLINI, Ariovaldo Augusto. Uma visão senequiana da amizade. Letras Clássicas, São Paulo, n 03, São Paulo, 1999, pp. 95/108.

PETIT, Paul. A paz romana. São Paulo: Edusp/Pioneira, 1989.

PIGANIOL, André. "Les empereurs parlent aux esclaves". In: PIGANIOL, André. Scripta Varia, v. 3. Bruxelas: Latomus, 1973, pp. 202-211.

POSTER, Mark. Introduction. Cultural History and Postmodernity. New York: Columbia University Press, 19?, pp. 03/13.

QUIROGA, P. L. B. de. La dependence economica de los libertos enel Alto Imperio Romano. Gerión 9, 1991.

. Freedmen Social Mobility in Roman Italy. Historia, 44, 1995, pp. 326348.

RAGO, Margareth. O efeito-Foucault na historiografia brasileira. Tempo Social, São Paulo, 7 (1-2), outubro, 1995, pp. 67/82.

REIS, R. (Re)lendo a história. In: PESAVENTO, S. J.; LEENHARDT, J. (org.) Discurso histórico e narrativa literária. Campinas: Unicamp, 1998, pp. 233/249.

REVILLA, Victor. Poder político, visibilidad social y honores en la Roma del siglo I d. C. In: BENOIT, Hector; FUNARI, Pedro Paulo A. Ética e política no mundo antigo. Campinas: Unicamp, 2001, pp. 253/264.

REICH, Wilhelm. Psicologia de massa do fascismo. Tradução de J. Silva Dias. São Paulo: Escorpião, 1974. 
REID, Donald. Reflections on labor history and language. In: BERLANSTEIN, Lenard R. Rethingking labor History. Chicago: University of Illinois Press, 199?, pp. 39/54.

RIST, John M. Seneca and stoic Orthodoxy. Aufstieg Und Niedergang Der Römischen Welt, vol. 36.3, Berlin, 1989, pp. 1993/2112.

ROBERT, Jean-Noël. Os prazeres em Roma. Tradução de Marina Appenzeller. São Paulo: Martins Fontes, 1995. . Les modes à Rome. Paris: Les Belles Lettres, 1998.

ROBIN, Régine. Langage et idéologies: le discours comme objet de l'Histoire. Paris: Ouvrières, 1974, pp. 03/11.

ROMAN, Yves. Folie de princes, paix du monde: Julio-Claudiens et Flaviens ou le premier Haut-Empire (14-96). In: Le Haut-Empire (27 av. J.-C.-235 ap. J.-C). Paris: Ellipses, 1998, pp. 43/64.

ROSTOVTZEFF, M. História de Roma. Tradução de Waltensir Dutra. Rio de Janeiro: Zahar, 1967.

ROUSSELLE, Aline. Pornéia: sexualidade e amor no mundo antigo. São Paulo: Brasiliense, 1983.

ROULAND, N. Pouvoir politique et dépendance personalle dans l'Antiquité romaine. Genèse et rôle des rapports de clientèle. Revue d'Études Latines, Bruxelles, 1979, pp. 499/580.

. Roma, democracia impossível? Os agentes do poder na urbe romana. Brasília: UNB, 1997.

ROYO, M. L'Octavie: entre Néron et les premiers Antonins. Revue des Études Latines, Paris, Les Belles Lettres, 61 année, 1983, pp. 189/200.

RUDICH, Vasily. Political dissidence under Nero: the price of dissimulation. London: Routledge, 1993.

SALLER, Richard. Personal Patronage under the Early Empire. Cambridge: Cambridge University Press, 1982.

- Patronage and friendship in early imperial Rome: drawing the distinction. In: WALLACE-HADRILL, A. Patronage in ancient society. London and New York: Routledge, 1990, pp. 49/62.

SALLES, C. Nos submundos da Antigüidade. São Paulo: Brasiliense, 1983.

SANTOS, Ailton P. dos. O poder do discurso. Belo Horizonte: Impr. Oficial, 1984. 
SANTOS, Pedro Brum. A representação da História e as fronteiras da composição literária. Vidya 24, no 24, jul/dez., 1995, pp. 07/15.

SANTOS, Ronildo Alves. Sobre a virtude estóica. Campinas: Unicamp, 2002 (Dissertação de Mestrado).

SANTOS, Tarcyanie Cajueiro. Dos espetáculos de massa às torcidas organizadas: paixão, rito e magia no futebol. São Paulo: Annablume, 2004.

SARAMAGO, José. Protopoema. In: Provavelmente Alegria. Lisboa: Caminho, 1985, pp. 54/55.

SEMANA, Paolo. Linguagem e poder. Brasiliense: UNB, 1984.

SENA, A. Teixeira. A semântica do poder. São Paulo: SN, 1985.

SEVERY, Beth. Family and State in the Early Imperial Monarchy: the Senatus Consultum de Pisone Patre, Tabula Siarensis, and Tabula Hebana. Classical Philology, vol. 95, no 3, Jul., 2000. p. 318-337.

SILVA, Gilvan Ventura. Política e ideologia e arte poética em Roma: Horácio e a criação do Principado. Politéia, Vitória da Conquista, v. 1, no 1, 2001, p. 2951.

. Reis, santos e feiticeiros: Constâncio /l e os fundamentos místicos da basileia (337 - 361). Vitória: Edufes, 2003.

SCHMITT, Carl. La notion du politique; théorie du partisan. Paris: CalmannLévy, 1972.

. Théologie politique. Paris: Gallimard, 1988.

SCULLARD, H. H.. From the Gracchi to Nero: a history of Rome (133 B.C. to A.D. 68). London: Routledge, 2001.

SCHIAVONE, Aldo. La storia spezzata: Roma antica e Occidente moderno. Roma: Laterza, 1996.

SCHWARCZ, L. M. As barbas do imperador: D. Pedro II, um monarca nos trópicos. São Paulo: Companhia das Letras, 1998.

STRINATI, Dominic. Cultura Popular: uma introdução. Tradução de Carlos Szlak. São Paulo: Hedra, 1999.

SULLIVAN, J. P. Literature and politics in the age of Nero. London: Cornell Universsity Press, 1985.

TAVARES, A. A. Impérios e propaganda na Antigüidade Clássica. Lisboa: Presença, 1988.

TERCAN, R. Vivre a la cour des Cesars. Paris: Les Belles Lettres, 1987. 
TREGGIARI, Susan. Social status and social legislation. The Cambridge Ancient History, Vol. 10, Cambridge University Press, 19?, pp. 873/904.

TORRI, M. B. Augusto e a construção do culto imperial. São Paulo: FFLCH, 1999.

TOWNEND, Gavin. Literature and society. The Cambridge Ancient History, Vol. 10, Cambridge University Press, 1996, pp. 905/929.

THEML, Neyde. Linguagens e formas de poder na Antigüidade. Rio de Janeiro: Faperj/Mauad, 2002.

THOMPSON, E. P. Costumes em comum. Estudos sobre a cultura popular tradicional. São Paulo: Companhia das Letras, 1998.

TURCAN, R. Vivre a la cour des Cesars. Paris: les Belles Lettres, 1987.

ULLMANN, R. A. O estoicismo romano: Sêneca, Epicteto e Marco Aurélio. Porto alegre: EDIPUCRS, 1996.

VAN RAIJ, Cleonice Furtado de Mendonça. Fedra de Sêneca: discurso literário e perspectivas para um estudo filosófico. São Paulo: FFLCH, 1992 (Tese de Doutoramento).

. A filosofia da dor nas consolações de Sêneca. Letras Clássicas, no 03, São Paulo, 1999, pp. 11/22.

VENTURINI, R.. Relações de poder em Roma: o patronato e a clientela. Clássica, São Paulo, v. 11/12, no 11/12, 1998/1999, pp. 297/305.

VERBEKE, Gerard. Le stoïcisme, une philosophie sans frontiers. Aufstieg Und niedergang der Römischen Welt, vol. 36.3, Berlin, 1973, p. 12/42.

VEYNE, P. Le pain et le cirque: sociologie historique d'um pluralisme politique. Paris: Seuil, 1976. . Indivíduo e poder. Lisboa: Ed. 70, 1987. . O império Romano. In: DUBY, G. \& ARIÈS, P. História da vida privada. São Paulo: Companhia das Letras, 1989, pp. 19/223. . Sobre el individuo. Barcelona: Paidos, 1990. . La vita privata nellimpero romano. Roma: Laterza, 1992. . Sociedade romana. Lisboa: Ed. 70, 1993.

VERNANT, Jean-Pierre. Entre mito e política. São Paulo: Edusp, 2002.

VOELKE, André-Jean. L'idée de volonté dans le stoïcisme. Paris: Presses Universitaires de France, 1973.

WALTZ, René. Vie de Sénèque. Paris: Librairie Académique, 1909. 
WALLACE-HADRILL, A. Patronage in Ancient Society. London and New York: Routledge, 1990.

. Introduction. In: WALLACE-HADRILL (org). Patronage in Ancient Society. London and New York: Routledge, 1990, pp. 1/13.

. Patronage in Roman society: from Republic to Empire. In: In: WALLACE-HADRILL (org). Patronage in Ancient Society. London and New York: Routledge, 1990, pp. 63/87.

. The emperor and his virtues. Historia, 30, 1991, pp. 298/322.

. The Imperial Court. In: BOWMAN, A. K., CHAMPLIN, E. and LINTOTT, A. The Cambridge Ancient History, Vol. X, Cambridge: Cambridge University Press, 1996, pp. 283/308.

WALTER, B. The mask of power. Seneca's tragedies and imperial Rome. Chicago: Bolchazs Carducci Publishers, 1985.

WEAVER, P. R. C. Mobilidad social en el alto imperio romano: la evidencia de los libertos imperials y los esclavos. In: FINLEY, Moses I. (org.). Estudios sobre Historia Antigua. Tradução Ramón López. Madrid: Akal Editor, 1981, pp. 137/156.

WIDEMANN, Thomas. Emperors na Gladiators. Routledge: London and New York, 1992.

WILLIAMS, R. Cultura. Tradução de Lolo L. Oliveira. São Paulo: Paz e Terra, 1992.

WISTRAND, M. Violence and entertainment in Seneca the younger, Eranos, 88, 1990, pp. 31-46.

WHITTAKER, C. R.; GARNSEY, Peter. Trade and famine in Classsical Antiquity. Cambridge University Press, 1983.

WHITE, H. Teoria Literária e Escrita da História. Estudos Históricos, Rio de Janeiro, vol. 07, oㅜ 13, 1994, pp. 21/48.

- Trópicos do discurso: ensaios sobre a crítica da cultura. São Paulo: Edusp, 2001.

. A poética da História. In: Meta-História: a imaginação histórica do século XIX. Tradução de José Laurêncio de Melo. São Paulo: EDUSP, 19?, pp. $17 / 56$.

WOOD, Ellen Meiksins. Peasant-Citizen and slave. The foudations of Athenian Democracy. New York: Verso, 1988. 
YAVETZ, Z. Plebs and Princeps. Oxford: Oxford University Press, 1969.

ZEILINGER, Anton. A face oculta da natureza. O novo mundo da física quântica. São Paulo: Globo, 2005.

\section{Obras de referência}

BOBBIO, Norberto. Dicionário de Política. México: Siglo Veintiuno, 1988.

COELHO, Teixeira. Dicionário crítico de política cultural. Cultura e imaginário. São Paulo: FAPESP/ lluminuras, 1997.

DAREMBERG, C; SAGLIO, E; POTTIER, E. Dictionnaire des Antiquités Grecques et Romaines. Paris, 1877-1919.

GREIMAS, A. J.; COURTÉS, J. Dicionário de semiótica. São Paulo: Cultrix, 199? HORNBLOWER, Simon; SPAWFORT, Antony. The Oxford Classical Dictionary. Oxford: Oxford University Press, 1996.

MACHADO, José Pedro. Dicionário etimológico da língua portuguesa. Lisboa: Confluência, 1967.

SARAIVA, F. R. dos Santos. Dicionário latino-português. Rio de Janeiro/Belo Horizonte: Garnier, 1999. 


\section{ANEXOS}




\section{ANEXO I:}

Cidade de Nascimento de Sêneca: Córdoba ${ }^{149}$

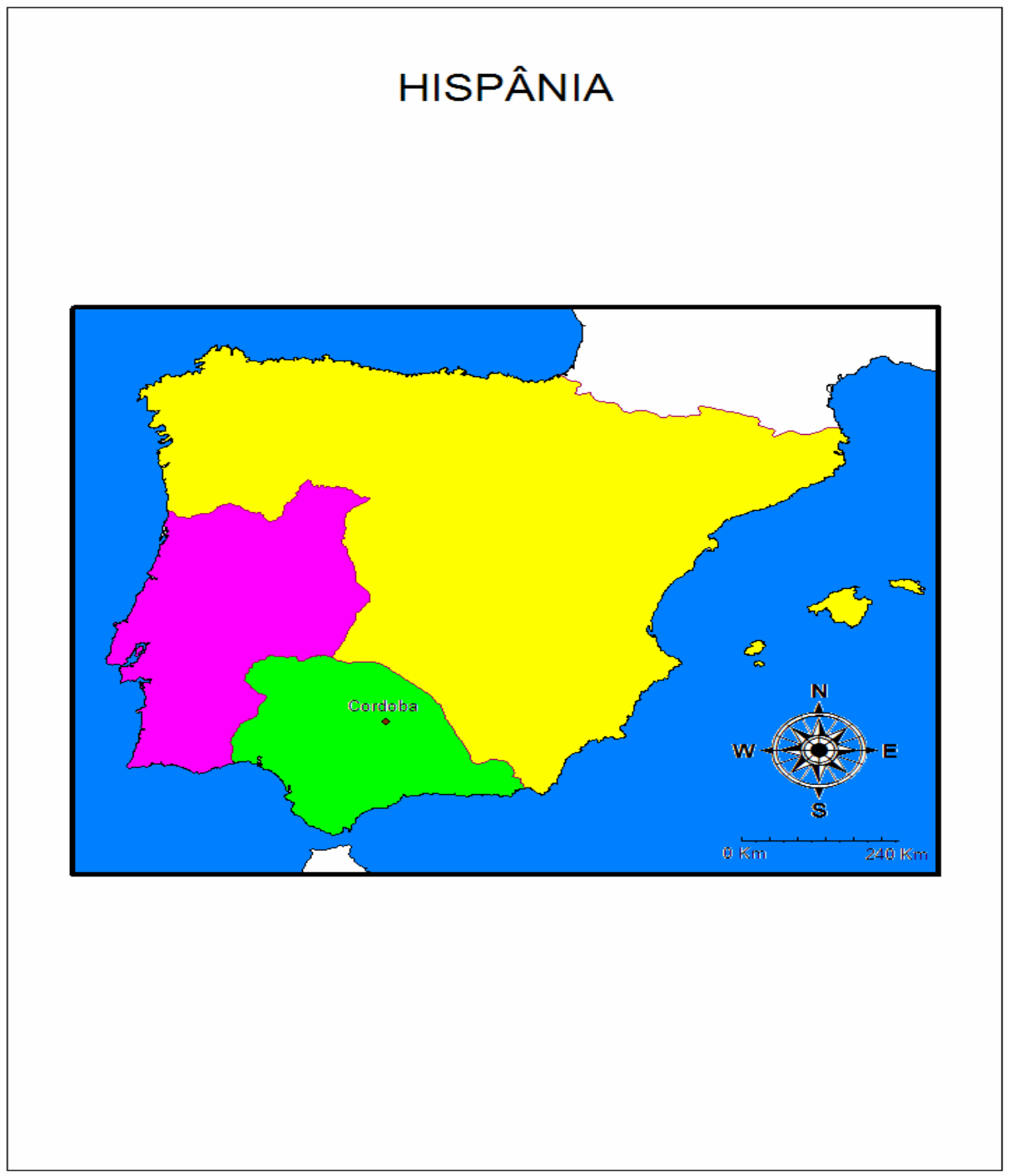

${ }^{149} \mathrm{O}$ anexo I é uma figura elaborada por Altino Silveira Silva que se baseou na seguinte obra: Grant, M. Atlas of Classical History. London: Routledge, 1994. 


\section{ANEXO II}

\section{Pesquisa Mensal de Emprego - PME}

\section{FONTE: IBGE - INSTITUTO BRASILEIRO DE GEOGRAFIA E ESTATÍSTICA ${ }^{150}$}

Estimativas do Mês de Outubro de 2006 (em mil pessoas)

Região Metropolitana: São Paulo

Em mil pessoas

Idade Mínima: 10 anos

\begin{tabular}{|l|c|}
\hline \multicolumn{1}{|c|}{ Especificação } & Out/06 \\
\hline Pessoas em Idade Ativa & 16.317 \\
\hline Pessoas Economicamente Ativas & 9.792 \\
\hline Pessoas Não Economicamente Ativas & 6.525 \\
\hline Pessoas Ocupadas & 8.782 \\
\hline Pessoas Desocupadas & 1.010 \\
\hline Pessoas Subocupadas por Insuf. Horas Trabalhadas & 278 \\
\hline Pessoas Ocupadas c/ Rend. Hora< Sal.Min./Hora & 1.013 \\
\hline Emp. com Carteira de Trabalho Assinada no setor privado(*) & $\mathbf{3 . 9 2 2}$ \\
\hline Emp. sem Carteira de Trabalho Assinada no setor privado(**) & $\mathbf{1 . 4 6 7}$ \\
\hline Taxa de Ocupação & 89,7 \\
\hline Taxa de Desocupação & 10,3 \\
\hline Percentual de pessoas sub-ocupadas por insuf. de horas trab. & $\mathbf{3 , 2}$ \\
\hline Percentual de pessoas ocupadas c/ rend./hora< sal.min./hora & $\mathbf{1 1 , 5}$ \\
\hline Empregados com Carteira de Trabalho Assinada (***) & $\mathbf{4 9 , 0 0}$ \\
\hline Empregados sem Carteira de Trabalho Assinada (***) & $\mathbf{2 2 , 7}$ \\
\hline
\end{tabular}

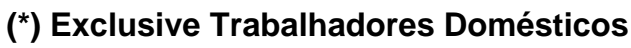

(**) Exclusive Trabalhadores Domésticos e Trabalhadores Não Remunerados de Membro da Unidade Domiciliar que era Empregado

$\left.{ }^{* \star \star}\right)$ Inclusive Trabalhadores Domésticos

150 
This document was created with Win2PDF available at http://www.win2pdf.com.

The unregistered version of Win2PDF is for evaluation or non-commercial use only.

This page will not be added after purchasing Win2PDF. 